Universidade de São PaUlo

FACUldade DE Filosofia, LeTRAs E CIÊNCIAS Humanas

DEPARTAMENTO DE LINGÜÍSTICA

Programa de Pós-GraduaÇÃo EM LINGÜÍstica

\title{
Da indissociabilidade entre o ensino de língua e de literatura: uma proposta para o ensino do italiano como língua estrangeira em cursos de Letras
}

Elisabetta Santoro

Tese apresentada ao Programa de Pós-Graduação em Lingüística do Departamento de Lingüística da Faculdade de Filosofia, Letras e Ciências Humanas da Universidade de São Paulo, para a obtenção do título de Doutor em Letras.

Orientador: Prof. Dr. José Luiz Fiorin

São Paulo

2007 
À minha mãe e à minha irmã, que, mesmo distantes, sempre estiveram presentes. Ao meu pai, cuja lembrança sempre me acompanha. Ao Roger que esteve comigo todos os dias. Sem eles não seria o que sou e não teria feito o que fiz. 


\section{AgRADECIMENTOS}

A José Luiz Fiorin, meu orientador, que acreditou em mim desde o início e me deu apoio, força e conselhos até o final.

A Andrea Lombardi, que me ajudou a encontrar o caminho.

A Norma Discini, que me fez apaixonar pela semiótica.

A Neide González, que esteve sempre pronta para conversas sobre o mundo das línguas estrangeiras.

Aos colegas da Área de Língua e Literatura Italiana do Departamento de Letras Modernas da Faculdade de Filosofia, Letras e Ciências Humanas da Universidade de São Paulo, que apoiaram meu pedido de um semestre dedicado exclusivamente à pesquisa.

Aos meus alunos que acreditaram no que eu acreditei e, como eu, se apaixonaram.

A Cecilia Casini, Alexandre Antoniazzi e Patrícia Deviciente, que me ajudaram a transformar a língua em "números".

Aos colegas e amigos Anna Rita Tamponi, Ineke Vedder, Gabriele Pallotti, Marco Mezzadri, Donata Puntil, Tokiko Ishihara, que, de perto ou de longe, fizeram chegar dicas, ajuda, artigos, livros...

A todos os amigos que suportaram minhas conversas "monotemáticas" dos últimos tempos. 
[...] a chi crede nella necessità che l'immaginazione abbia il suo posto nell'educazione; [...] a chi sa quale valore di liberazione possa avere la parola. «Tutti gli usi della parola a tutti» mi sembra um buon motto, dal bel suono democratico. Non perché tutti siano artisti, ma perché nessuno sia schiavo.

Gianni Rodari

Vivendo, se aprende; mas o que se aprende, mais, é só a fazer outras maiores perguntas.

Guimarães Rosa 


\section{RESUMO}

Muito se escreveu sobre a integração entre ensino de língua e ensino de literatura e entre estudos lingüísticos e estudos literários. Entretanto, observa-se que a separação entre língua e literatura persiste, embora a literatura não seja pensável fora dos quadros da língua e a língua desenvolva suas máximas potencialidades na literatura.

Muitos métodos de ensino de língua estrangeira recomendam que se comece a aquisição/aprendizagem de uma língua estrangeira com textos que utilizam a linguagem em função utilitária e que, mais tarde, se introduzam textos que se valem da função poética. Ao contrário, esta tese parte da hipótese de que um curso de língua pode sempre estar baseado em textos com função poética. Os textos não foram usados pretextualmente como fonte de estruturas gramaticais, pois a idéia que guiava a preparação do material didático utilizado nas aulas é que o aumento da capacidade de interpretar textos ocorre simultaneamente à aquisição das estruturas lingüísticas. Visando a pôr a prova essa convicção, duas turmas de alunos brasileiros da habilitação em Língua e Literatura Italiana de um curso de bacharelado em Letras foram acompanhados ao longo de todo um programa experimental de ensino com uma duração de três anos, em que língua e literatura foram estudadas conjuntamente a partir de textos literários analisados com base nos princípios da semiótica francesa.

No percurso didático os alunos construíam uma relação cada vez mais autônoma com os textos, observando e analisando as estruturas organizadoras do sentido e a funcionalidade discursiva dos fatos gramaticais.

No final de cada ciclo de aulas os discentes produziam análises escritas dos textos poéticos utilizados em sala de aula. Essas análises foram examinadas para verificar, por um lado, por meio dos critérios de fluência, precisão, complexidade e variação lexical, a competência lingüística; e, por outro, a competência discursiva, isto é, a capacidade de os alunos perceberem as relações no interior do texto e os efeitos de sentido que produzem.

Os resultados mostraram a eficácia de um ensino que se baseia na análise de textos literários. De fato, registrou-se um desenvolvimento da interlíngua dos discentes que se manifestou por meio do aumento de todos os valores e também um aprimoramento da capacidade de análise que os levou a ser leitores e produtores de textos cada vez mais competentes.

Palavras-Chave: ensino de língua estrangeira; didática de línguas; semiótica francesa 


\begin{abstract}
A lot has been written on the integration between language and literature teaching, and between linguistic and literary studies. Nevertheless, we can observe that the separation between language and literature persists, although literature cannot be thought outside the structures of language and language develops in literature its highest potentialities.

Many methodologies for foreign language teaching suggest that the acquisition/learning should begin with texts that use language with utilitarian function and, only later, texts with poetic function. This thesis hypothesis is, on the contrary, that a language course can be always based upon texts with poetic function. Therefore, texts have not been used as pre-text and as source of grammatical structures, since the idea that guided the preparation of the pedagogical material used during the lessons is that the growing of the capacity of interpreting texts takes place simultaneously with the acquisition of linguistic structures. In order to test this conviction, two groups of Brazilian students of Italian Language and Literature of a university course of Letters were followed along a whole experimental program with a duration of three years. In this course Italian language and literature were studied in an integrated way on the basis of literary texts analyses, accomplished with the principles of French semiotics.

During the course the students built a more and more autonomous relation with the texts, observing and analyzing the structures which organize the meaning and the discursive functionality of the grammatical facts and, at the same time, took possession of the foreign language.

At the end of every cycle of lessons the students produced their own analyses of the poetic texts used in the classroom. These analyses were examined in order to verify, at one side, the linguistic competence through the measures of fluency, accuracy, complexity and lexical variation; and, at the other, the discursive competence, that is, the capacity of the learners to notice relations in the interior of the text and the meaning effects that they produce.

The results have showed the effectiveness of this way of teaching that bases upon the analyses of literary texts. It was registered a development of the interlanguage of the students shown through the increase of all the measures results, besides an improvement of the capacity in the text analyses which brought them to reach a growing proficiency as text readers and producers.
\end{abstract}

KEY-WORDS: foreign language teaching; language didactics; French semiotics 


\section{RIASSUNTO}

Si è molto scritto sull'integrazione tra l'insegnamento della lingua e della letteratura e tra gli studi linguistici e gli studi letterari. Si osserva, tuttavia, che la separazione tra lingua e letteratura persiste, nonostante la letteratura non sia pensabile al di fuori delle strutture della lingua e la lingua sviluppi nella letteratura le sue massime potenzialità.

Molte metodologie per l'insegnamento delle lingue straniere prevedono che si inizi l'acquisizione/apprendimento di una lingua straniera con testi che utilizzano il linguaggio con funzione utilitaria e che, solo più tardi, si introducano testi che si valgono della funzione poetica. Questa tesi parte, invece, dall'ipotesi che un corso di lingua può essere sempre basato su testi con funzione poetica. I testi non sono quindi stati usati pretestualmente come fonte di strutture grammaticali, visto che l'idea di base che guidava la preparazione del materiale didattico utilizzato durante le lezioni è che l'aumento della capacità di interpretare testi si realizza simultaneamente all'acquisizione delle strutture linguistiche. Al fine di mettere alla prova questa convinzione, due gruppi di studenti brasiliani di Lingua e Letteratura Italiana di un corso di laurea in Lettere sono stati seguiti lungo tutto un programma sperimentale di insegnamento durato tre anni, in cui la lingua e la letteratura italiana sono state studiate in maniera integrata sulla base dell'analisi di testi letterari realizzata a partire dai principi della semiotica francese.

Nel percorso didattico gli studenti costruivano un rapporto sempre più autonomo con i testi, osservando e analizzando le strutture che organizzano il senso e la funzionalità discorsiva dei fatti grammaticali e, al tempo stesso, si appropriavano della lingua straniera.

Alla fine di ogni ciclo di lezioni gli studenti producevano le loro analisi dei testi poetici utilizzati in classe. Queste analisi sono state esaminate per verificare, da una parte, la competenza linguistica, tramite i criteri di fluenza, accuratezza, complessità e variazione lessicale; e, dall'altra, la competenza discorsiva, ovvero, la capacità degli apprendenti di notare e analizzare le relazioni all'interno del testo e gli effetti di senso che producono.

I risultati hanno evidenziato l'efficacia di un tipo di insegnamento che si fonda sull'analisi di testi letterari. Si è infatti registrato uno sviluppo dell'interlingua dei discenti che si è manifestato attraverso l'aumento di tutti i valori misurati, oltre a un miglioramento della capacità di analisi che li ha portati a essere lettori e produttori di testo sempre più competenti.

Parole-Chiave: insegnamento di lingue stranierea; glottodidattica; semiotica francese 


\section{SUMÁRIO}

. Introdução

p. 3

1. A tradição dos cursos de Letras

p. 5

2. O ensino de línguas estrangeiras e o texto literário: dos métodos tradicionais à abordagem comunicativa

p. $\quad 10$

3. A integração do ensino de língua e do ensino de literatura: uma proposta para o italiano como língua estrangeira

p. $\quad 16$

4. A semiótica no ensino da língua e da literatura

p. $\quad 21$

5. O curso experimental

p. $\quad 34$

6. Plano da tese

p. 40

1. Textos literários para o ensino do italiano como língua estrangeira:

uma análise semiótica

p. $\quad 44$

1.1. Os contos

p. 44

1.1.1. Luca non dimentica - Gabriele Romagnoli

p. $\quad 55$

1.1.2. Occhi di Paola - Gabriele Romagnoli

p. $\quad 75$

1.1.3. L'onorevole doppia chance - Gabriele Romagnoli

p. $\quad 91$

1.2. Os poemas

p. $\quad 116$

1.2.1. Ha partorito - Giorgio Manacorda

p. $\quad 122$

1.2.2. Se ora tu bussassi alla mia porta - Patrizia Cavalli

p. $\quad 136$

1.2.3. La poesia oggi - Sebastiano Vassalli

p. $\quad 149$

2. O currículo e as atividades didáticas

p. $\quad 162$ 
2.1. As "tarefas" num currículo multidimensional

p. $\quad 162$

2.2. As atividades didáticas: um percurso da leitura à escrita

p. $\quad 172$

3. A avaliação das produções escritas dos aprendizes

p. $\quad 206$

3.1. Avaliação da competência lingüística

p. $\quad 212$

3.2. Avaliação da competência discursiva

p. $\quad 242$

. Conclusões

p. $\quad 268$

. Bibliografia

p. $\quad 272$

. Anexo I: As atividades didáticas

p. $\quad 287$

. Anexo II: As produções escritas dos aprendizes

p. $\quad 306$ 


\section{INTRODUÇÃO}

Em texto publicado em espanhol em 1977 e traduzido para o português em 1982, o lingüista romeno Eugenio Coseriu postula a identidade entre linguagem e poesia, já que - diz ele - apenas a linguagem poética ativa uma complexa rede de relações, que nos outros usos lingüísticos se tornam inoperantes:

Por conseguinte, a linguagem poética revela-se, não um uso lingüístico entre outros, mas linguagem simplesmente (sem adjetivos): realização de todas as possibilidades da linguagem como tal. (COSERIU, 1982: 146)

A "linguagem poética", que é poiesis, criação, atividade e "fazer" com a língua (do grego

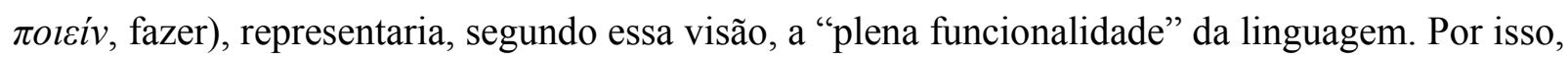
os textos poéticos seriam o lugar mais rico dos desdobramentos da língua, necessários para observá-la e estudá-la, enquanto as outras manifestações lingüísticas seriam usos específicos da linguagem, reduções que não desenvolvem todas as suas virtualidades.

Pode-se discutir se a hipótese da absoluta coincidência entre linguagem e poesia é sustentável ou não. A certa altura o próprio Coseriu parece contradizê-la. De qualquer maneira, ela nos confronta com uma questão muito discutida e polêmica: a questão da relação entre língua e literatura, entre o texto literário e a língua de que é feito. 
Muito já foi escrito sobre esse assunto e muitos argumentaram em favor da necessidade de união entre esses dois campos do saber, defendendo que língua e literatura constituem um binômio inseparável, visto que a língua não seria pensável sem a literatura e a literatura não seria possível sem a língua.

De fato, a língua estabelece relações, traça fronteiras, produz conceitos, transmite idéias, veicula interpretações e tudo isso é indispensável para que se faça literatura, que só pode ser realmente "descoberta" analisando e lendo em profundidade a língua que a constitui.

Por outro lado, a literatura abre novos espaços, admite contradições, permite jogos, comporta ambigüidades, amplia potencialidades e tudo isso é imprescindível para entender e conhecer a língua, inclusive porque, como diz Denis Bertrand, "a literatura exerce [...] por natureza, uma função crítica sobre a língua, desaprumando-a em relação a si mesma em cada obra" (2003: 25).

Língua e literatura são, contudo, ainda hoje, em muitas situações, domínios separados, são tratadas como disciplinas distintas e, portanto, ensinadas e estudadas sem estabelecer contatos ou criar ligações. Embora unidas em nomes de cursos universitários e pronunciadas como sintagma coeso e sólido em tantas ocasiões, língua e literatura permanecem ainda, na maior parte dos casos, dois campos separados do saber e, tanto nas escolas, quanto nas universidades, uma efetiva integração até hoje não se realizou.

Como antecipamos no título deste trabalho, o que queremos afirmar aqui é, em primeiro lugar, a indissociabilidade entre o ensino de língua e o ensino de literatura. Explicaremos mais 
adiante, com mais detalhes, como e por que, mas um primeiro aspecto que nos leva à defesa da diluição da dicotomia língua/literatura é que, a nosso ver, ambas encontram-se no texto literário. De fato, consideramos que a literatura é o texto literário, o qual, portanto, deveria representar a base de qualquer curso, em qualquer nível e em qualquer situação, e achamos, por outro lado, que o texto literário, enquanto realização de todas as potencialidades da linguagem, deveria ser essencial também em cursos de língua. Levando em conta isso, reputamos indispensável a reflexão sobre intersecções e confluências entre essas duas áreas que, aparentemente divididas por intransponíveis barreiras metodológicas, na verdade, são, ou podem ser, uma só.

Ainda que muitas de nossas reflexões sobre língua e literatura não sejam específicas de uma determinada situação de ensino, concentrar-nos-emos na realidade em que atuamos e tomaremos, portanto, como referência a Área de Língua e Literatura Italiana do curso de Letras da Faculdade de Filosofia, Letras e Ciências Humanas da Universidade de São Paulo. Isso significa que especial atenção será dedicada a considerações sobre os cursos de Letras em geral, sobre a formação dos profissionais das Letras e sobre as peculiaridades do ensino das Línguas e das Literaturas Estrangeiras e, mais especificamente, da Língua e da Literatura Italiana para falantes de português.

\section{A TRADIÇÃOdOS CURSOS DE LETRAS}

Os cursos de Letras refletem a divisão que acompanha desde sempre os campos dos estudos literários e dos estudos lingüísticos. Em seu conhecido ensaio "Lingüística e poética", 
originalmente apresentado como conferência na Indiana University em 1958, Jakobson mostrou de forma clara e contundente como lingüistas e estudiosos da literatura raramente dialogam e quanto cada uma das duas áreas poderia avançar, se não ignorasse a outra. Jakobson conclui sua argumentação com a seguinte afirmação:

[...] um lingüista surdo à função poética da linguagem e um especialista de literatura indiferente aos problemas lingüísticos e ignorante dos métodos lingüísticos são, um e outro, flagrantes anacronismos. (1977: 162)

Voltaremos a esse ensaio mais à frente; por enquanto, cabe ressaltar que essas reflexões não parecem ter influenciado os rumos dos cursos de Letras. Desde o início de suas vidas acadêmicas, os alunos vivem língua e literatura como mundos separados e são levados, pela própria organização curricular, a perceber mais as diferenças do que as analogias entre essas duas disciplinas. De fato, pela maneira como são estruturados, os cursos induzem-nos a formar-se numa lógica da separação, numa mentalidade dos compartimentos estanques que reforça e reitera um rígido sistema de ensino, no qual se prefere a comodidade da repetição de esquemas consolidados ao desafio da integração.

Para melhor entender como se originaram algumas das crenças que, em parte, perduram até hoje, pode ser útil observar como foram dados os primeiros passos dos cursos de Letras no Brasil. Tomaremos como exemplo o curso da então Faculdade de Filosofia, Ciências e Letras da Universidade de São Paulo, fundado não só nessa "cultura da divisão", mas também na convicção da superioridade dos estudos literários em relação aos estudos lingüísticos. 
Entre 1937 e 1954, a Faculdade promoveu a publicação de Anuários relativos aos anos de 1934 (ano de sua criação) a 1952. Entre outras coisas, nos Anuários eram descritos os diferentes cursos da Faculdade, eram fornecidos dados numéricos e eram transcritas as aulas inaugurais, os programas e os objetivos das disciplinas. Além disso, os professores responsáveis pelas diferentes cátedras eram convidados a escrever artigos, nos quais expunham sua experiência na Faculdade, discorriam sobre a relevância dos estudos em suas disciplinas e sobre seu possível desenvolvimento, dando inclusive sugestões a respeito de como poderia ser melhorado o ensino universitário.

É significativo para as nossas considerações sobre estudos lingüísticos e estudos literários ler no texto do professor Francisco da Silveira Bueno que "para os lingüistas, as qualidades literárias do texto de pouco ou nada valem" (Anuário, 1953: 85), porque eles estariam interessados na língua como tal e, portanto, não na literatura. O escrito do professor de Filologia visava a evidenciar as diferenças entre lingüistas e filólogos - aqueles atraídos apenas pela "língua em que está escrito o documento", enquanto para estes "a língua é apenas um instrumento, um auxiliar que o ajuda a criticar o escrito, a avaliar da sua época" (Anuário, 1953: 85) -, mas dá claros indícios sobre a maneira como eram vistos os lingüistas e a lingüística e sobre a distância que, segundo se considerava, existia entre o mundo da língua e o da literatura.

$\mathrm{Na}$ nossa busca de indicações quanto às relações entre língua e literatura, encontramos sinais ainda mais evidentes de separação nos relatórios das cadeiras de Línguas e Literaturas Estrangeiras. Nelas são mencionados, às vezes, cursos e aulas de língua, dos quais não se encontram, porém, referências nos programas, já que estes contêm exclusivamente tópicos de literatura. 
Lendo, por exemplo, o primeiro programa do professor Francesco Piccolo, que ocupou em 1934 a cátedra de Língua e Literatura Italiana ${ }^{1}$, observamos que prevê o estudo de Dante, Angelo Poliziano, Lorenzo de' Medici e Ariosto para ilustrar alguns momentos essenciais da literatura italiana, mas não faz menção alguma ao estudo da língua e a como esse se daria (Anuário, 1937: 294). Os programas dos anos seguintes são redigidos nos mesmos moldes do primeiro.

Quando, em 1937, o poeta Giuseppe Ungaretti é chamado da Itália para substituir o antigo professor, em seu primeiro programa faz constar, além do programa de literatura, uma parte dedicada à língua. No entanto, o tema previsto nada tem em comum com um estudo lingüístico assim como o entendemos hoje: o programa propõe o estudo da teoria sobre a língua de Leopardi e a leitura da obra do poeta com comentários de seus textos (Anuário, 1938: 364).

Bastam essas observações para perceber que a tradição do curso de Letras da USP não só separa língua e literatura, mas enfatiza a literatura em detrimento à língua: não havia interesse no ensino das línguas - em especial, das línguas estrangeiras - e os professores lamentavam que os estudantes não chegassem à universidade com conhecimentos prévios, porque isso significava não poder "elevar-se dos conhecimentos das línguas ao conhecimento histórico e crítico das literaturas" (Anuário, 1937: 211), como escreve o professor Piccolo, referindo-se em especial à falta do estudo das línguas clássicas no currículo escolar, já que - afirma o professor - os alunos "balbuciam o italiano ou o francês [e] não conhecem sequer os primeiros elementos da língua latina ou da língua grega" (Anuário, 1937: 210).

\footnotetext{
${ }^{1}$ Em 1934 começaram apenas as aulas das Cadeiras de Língua e Literatura Italiana e Língua e Literatura Francesa. As Cadeiras Língua e Literatura Alemã, Língua e Literatura Espanhola e Língua e Literatura Inglesa, embora previstas, tiveram seu início efetivo só em 1940.
} 
Uma queixa do mesmo tipo está presente também no Anuário relativo aos anos de 1939 a 1949. No volume em que são indicadas e comentadas as atividades docentes, há um relatório da cadeira de Língua e Literatura Italiana e, a uma certa altura, lê-se o seguinte:

Os candidatos à Faculdade de Filosofia ingressam nos cursos da Cadeira sem que lhes seja exigido, por exame, qualquer conhecimento de Língua ou Literatura Italiana. É esta uma situação insustentável que poderia ser corrigida com a inclusão do estudo do italiano no $2^{\circ}$ ciclo do ensino médio como cadeira de livre escolha ou como disciplina de um curso préuniversitário (1953: 494).

Vê-se que a língua estrangeira é mencionada, mas apenas como instrumento para que possam ser lidos os textos literários originais. Em outras palavras: a língua estava a serviço da literatura, era pensada como conhecimento prévio das formas, do léxico e da gramática, que pudesse permitir compreender os textos de literatura estrangeira, estes sim vistos como a essência do curso, como aquilo que realmente contava na formação (cf. também FiORIN, 2007: 100-101). Os alunos deviam concentrar-se nos estudos mais nobres e "elevados" da literatura e a aprendizagem das línguas estrangeiras não devia, nem podia ter lugar dentro da universidade, onde se almejava uma instrução "verdadeiramente superior" e onde, portanto, a língua deveria ser um pré-requisito.

É evidente que o conhecimento da língua não implicava, nessa concepção, reflexões lingüísticas e que a atividade de ensinar uma língua (e aqui pensamos especialmente nas línguas estrangeiras) era, por isso, considerada inadequada ao contexto universitário, redoma dos intelectuais da interpretação literária epifânica e magistral, a que se chegava pela erudição, pela história, pelo estudo da crítica e dos críticos, e não pelo conhecimento profundo da língua e do seu funcionamento. 


\section{O ENSINO DE LÍNGUAS ESTRANGEIRAS E OTEXTO LITERÁRIO: DOS MÉTODOS TRADICIONAIS À ABORDAGEMCOMUNICATIVA}

Embora tivesse sido abertamente declarado não se considerar a universidade lugar adequado para isso, os cursos de Letras foram obrigados a encarregar-se também do ensino das línguas estrangeiras. Os currículos escolares do ensino fundamental e médio não previam o estudo de todas as línguas estrangeiras clássicas e modernas incluídas nesses cursos superiores e houve até épocas nas quais era possível concluir o percurso escolar sem nunca ter estudado sequer uma única língua estrangeira (LEFFA, 1999: 10). A universidade teve, portanto, de preparar os alunos para que pudessem iniciar suas carreiras universitárias na área das Letras, aprendendo as línguas estrangeiras para dedicar-se, depois da prática com a língua, aos estudos literários, que eram o que realmente importava.

Como já ressaltamos, nesse período o ensino do idioma era um ensino baseado na gramática, no léxico e nos exercícios de classificação. Além disso, no caso de uma língua nãomaterna, a atenção estava dirigida, antes de tudo, a aprender as maneiras "corretas" de expressarse no outro sistema lingüístico. As línguas eram consideradas conglomerados de estruturas gramaticais e palavras isoladas, que, uma vez estudadas e treinadas com listas e traduções, permitiriam a leitura dos textos, sobretudo os literários, que eram o objetivo final de todo o processo de aprendizagem. A metodologia tradicional previa, em suma, um único ponto de intersecção entre o ensino da língua e o ensino da literatura: o código lingüístico utilizado.

Nesse contexto, não é difícil imaginar que os textos literários possuíam um papel essencial nas aulas; eles eram, aliás, os únicos textos de referência, porque continham a língua que devia 
ser imitada e entendida. É por isso que geralmente se associa o uso da literatura na sala de aula de língua estrangeira às abordagens didáticas ditas tradicionais, nas quais o texto literário, julgado respeitoso das normas gramaticais e exemplo de uma "boa" realização lingüística, era o modelo que apresentava a língua correta e elevada ao aluno estrangeiro. O texto literário era, portanto, tratado como distante objeto de veneração, visto “[...] como aquilo que devíamos alcançar e como aquilo que jamais alcançaríamos. Falávamos dele, mas raramente com ele e muito menos dentro dele", diz González descrevendo a posição dos aprendizes de línguas estrangeiras ${ }^{2}$. E, de fato, o objetivo não era criar as condições para que os alunos pudessem "estabelecer uma vivência" com o texto literário, o qual, ao contrário, incorporando os valores de um determinado tipo de ensino, era visto como norma, perfeição, estabilidade, elevação do espírito, distância da banalidade do cotidiano e da língua utilitária e corrente.

À medida que as metodologias para o ensino das línguas estrangeiras foram mudando e que a dita "abordagem comunicativa" se foi afirmando, o texto literário foi, cada vez mais, substituído por textos que se acreditava pudessem refletir de forma mais fiel a língua falada e cotidiana, isto é, a língua da "verdadeira comunicação". Os adeptos dessa visão do ensino de línguas estrangeiras rejeitaram a idéia da importância do texto literário e, reagindo aos modelos antes vigentes, inverteram completamente a rota: em sua, a nosso ver, errônea interpretação do que é competência comunicativa, não consideraram "comunicativo" o texto literário e, portanto, não julgaram que pudesse ser integrado num ensino da língua estrangeira, no qual se ia consolidando a idéia de que era necessário concentrar-se na comunicação da "vida real" e nas

\footnotetext{
${ }^{2} \mathrm{O}$ texto do qual foi extraída essa citação foi publicado em espanhol ("[...] como aquello que debíamos alcanzar y como aquello que jamás alcanzaríamos. Hablábamos de él, pero raramente con él y mucho menos en él”, 1990: 117). Nesse caso, como em todos os outros em que o texto consta na bibliografia numa língua diferente do português, a tradução é nossa e o original será transcrito em nota.
} 
funções da linguagem, que permitem aprender a fala utilitária do dia-a-dia. Era essa a língua que devia ser estudada antes e sem a interferência de textos tão distantes do cotidiano como os textos literários, os quais prejudicariam ou retardariam a aquisição da competência comunicativa ${ }^{3}$.

A partir desse período, a literatura perdeu, portanto, seu papel central nas aulas de línguas estrangeiras, o que acentuou a separação entre o ensino de língua e de literatura. Eventualmente ela era utilizada apenas nos níveis avançados dos cursos de língua e essa convicção é até hoje extremamente difundida: considera-se que um aluno que ainda não conhece profundamente a língua estrangeira não pode entender os aspectos mais especificamente "literários" dos textos e que, portanto, é necessário prepará-lo antes; em outras palavras, prevalece a lógica que impõe, numa escala, cujos critérios não são sempre facilmente compreensíveis, que o fácil (a língua) anteceda o difícil (a literatura) e que o cotidiano e a "realidade" (a língua com função utilitária) venham antes do incomum e da "ficção" (a língua com função estética).

Curiosamente, a partir do auge da abordagem comunicativa, afirmou-se, portanto, uma posição que, em relação à presença da literatura na sala de aula de língua estrangeira, revela mais pontos de contato com a concepção tradicional, que - como vimos - tratava o texto literário como objeto de "veneração", do que com as metodologias posteriores, nas quais começaram a ganhar espaço visões muito mais dinâmicas e abrangentes de língua e de aprendizagem.

Em épocas mais recentes, somou-se a isso a opinião de alguns docentes e especialistas em didática das línguas estrangeiras, que afirmaram considerar desnecessário o uso de textos

\footnotetext{
${ }^{3}$ Muito foi escrito sobre a "abordagem comunicativa" e muitas são as indicações bibliográficas possíveis. Remetemos ao texto "clássico" The Communicative Approach to Language Teaching, organizado por Brumfit e Johnson (1979).
} 
literários como material didático, dada a abundância de textos que jornais, revistas, televisão e, principalmente, a internet nos colocam à disposição, iterando também que um aprendiz só pode dar conta de um texto literário, quando tiver alcançado um nível avançado no estudo da língua estrangeira.

É claro que essas posições não consideram os aspectos peculiares da função poética do texto literário, que, tratado como apenas mais um tipo de texto, é privado de seu potencial específico e identificado como o texto "difícil", além de sofrer uma sorte de "preconceito ao contrário": por ter sido já tão valorizado pelos métodos tradicionais, defender sua utilização em sala de aula soa aos ouvidos de muitos como anacronismo.

Mesmo o Quadro europeu comum de referência para as línguas: aprendizagem, ensino e avaliação (QECR), documento elaborado por vários especialistas em ensino/aprendizagem de línguas estrangeiras e publicado pelo Conselho da Europa em $2001^{4}$ como resultado de anos de estudos e pesquisas, raramente menciona os textos literários e, quando o faz, também considera a literatura como leitura para aprendizes nos últimos níveis (C1-C2), que se prepararam com textos cotidianos antes de estar prontos para “entender” o texto literário (cf. QECR, 2001: 53).

\footnotetext{
${ }^{4} \mathrm{O}$ título completo do documento no original em inglês é: Common European Framework of Reference for Languages: Learning, Teaching, Assessment. Em 2001 o volume foi publicado pelo Conselho da Europa em inglês e francês e, logo em seguida, foram encomendadas e realizadas as traduções na maior parte das línguas dos países da União Européia. Para o presente trabalho utilizamos a versão portuguesa (2001) e a italiana (2002). O Quadro Europeu Comum de Referência (QECR) divide em seis níveis gerais a organização da aprendizagem das línguas e indica descritores para que os aprendizes possam ser classificados nos diferentes níveis, que são: A1 (iniciação), A2 (elementar), B1 (limiar), B2 (vantagem), C1 (autonomia), C2 (mestria). Há ainda a denominação utilizador elementar para A1 e A2, utilizador independente para B1 e B2 e utilizador proficiente para C1 e C2 (QECR, 2001: 48).
} 
Assim, acontece ainda hoje que muitos livros didáticos para o ensino de línguas estrangeiras $^{5}$, mesmo quando dão algum espaço ao texto literário, restringem sua utilização aos níveis avançados e oscilam entre a visão tradicional, que o identificava com o modelo "sacralizado" de bom uso da língua, e a banalização das suas potencialidades. O trabalho com o texto limita-se, de fato, ao denotativo e à exemplaridade da língua utilizada.

Com a finalidade de verificar a "compreensão" são elaborados questionários, aos quais o aprendiz deve responder após a leitura. Muitas vezes, esses questionários são pouco ou nada desafiadores, pois as perguntas são óbvias e têm como objetivo verificar apenas a compreensão do que diz o texto em língua estrangeira. Uma vez comprovado que os alunos o "entenderam", ele pode ser usado para observar as estruturas gramaticais que contém e como ponto de partida para exercícios. Há também livros didáticos que partem da temática abordada e usam-na como estímulo para a conversação em sala de aula ou para a produção de um texto escrito, de forma que o aprendiz possa praticar a língua estrangeira e exercitar o que está aprendendo.

A conseqüência é que, num movimento contrário ao da ênfase na literatura, o aspecto mais especificamente literário (estético, múltiplo, denso) do texto é sacrificado para que se alcance a compreensão do enredo, da mensagem, do referente, da denotação, sem que se indique ao aprendiz quais são os caminhos por meio dos quais é gerado o sentido e sem que sejam exploradas as possíveis interpretações. Ou seja: a partir da leitura não se iniciam reflexões mais profundas sobre o funcionamento do texto, sobre os sentidos nele contidos e sobre a maneira como se dá a significação.

\footnotetext{
${ }^{5}$ Os manuais, aos quais nos referimos aqui, são especialmente os de Italiano como língua estrangeira, inclusive os mais recentes. Em geral e pelo que conhecemos, o tratamento dos textos literários não é muito diferente também na maioria dos livros didáticos para outras línguas estrangeiras.
} 
Por outro lado, em atividades didáticas como as que acabamos de descrever, a observação da língua pára no enunciado, só dá lugar à reutilização de formas e não constitui o ponto de partida para análises mais detalhadas e para poder aprender a perceber a gramática no texto como elemento que contribui para a criação de (novos) significados. A chamada "reflexão sobre a língua”, que muitos manuais didáticos incluem, limita-se geralmente a uma reconstrução, a partir dos elementos observados no texto, de como pode ser sistematizada uma "regra" gramatical e de quais são as normas que regem seu "uso", sendo que, em geral, não há espaço para efetivos questionamentos sobre os efeitos de sentido gerados e sobre como eles influenciam a leitura e a interpretação do texto.

Dessa maneira, deixa-se inutilizado o aspecto mais significativo da criação literária, aquilo que a transforma em algo especial, como muito bem escreve Graciela Reyes, afirmando que:

[...] citar a literatura como exemplo de língua culta prestigiosa [...] é um erro que surge da crença de que a literatura é a culminação do falar bem da comunidade. A literatura é muito mais do que isso, a partir de uma perspectiva lingüística: a literatura é um experimento que supõe um falar bem, consolida-o e perverte-o para inová-1o ${ }^{6}$.

Eis um dos pontos que nos leva à proposta de integração do ensino de língua e de literatura: o texto literário consolida, transforma, inova, equilibra e é, portanto, um texto cujas potencialidades são fundamentais no ensino em geral e indispensáveis para os alunos dos cursos

\footnotetext{
6 " [...] citar la literatura como ejemplo de lengua culta prestigiosa [...] es un error que surge de la creencia de que la literatura es la culminación del bien hablar de la comunidad. La literatura es mucho más que eso, desde una perspectiva linguística: la literatura es un experimento que supone un bien hablar, lo consolida y lo pervierte para inovarlo” (REYES, 1984: 193).
} 
de Letras, que, em sua formação, precisam de sólidos conhecimentos literários e de profundos conhecimentos lingüísticos para aprender a analisar, observar e vivenciar a linguagem.

Isso se torna ainda mais essencial, quando se aprende uma língua estrangeira e se estuda sua literatura, já que só na observação das confluências e na interação entre uma área e outra, o processo de aprendizagem pode tentar apreender a complexidade que representa o contato com um mundo outro por meio da linguagem, vista não apenas como um "instrumento", mas como a essência do ser humano, aquilo que realmente o constitui.

\section{A INTEGRAÇÃO DO ENSINO DE LÍNGUA E DE LITERATURA: UMA PROPOSTA PARA OENSINO DO ITALIANO COMO LÍNGUA ESTRANGEIRA}

Procuramos até aqui descrever o papel que o texto literário ocupou (e, em parte, ainda ocupa) no ensino em geral, nos cursos de Letras e no ensino/aprendizagem das línguas estrangeiras. Como vimos, a lógica dominante da separação, por um motivo ou por outro, continua prevalecendo e é raro, a nosso ver, poder observar movimentos de efetiva superação da divisão existente, em direção a uma valorização das relações, intersecções e confluências entre a língua e a literatura, entre os estudos lingüísticos e os estudos literários e entre o ensino de língua e o ensino de literatura.

Já citamos os dois principais argumentos em favor da união entre as duas áreas e, portanto, entre as duas disciplinas, e, por julgá-los fundamentais, os sintetizamos aqui mais uma vez: 
1) a língua da literatura é língua em funcionamento, é discurso, que desenvolve e atualiza todas as possibilidades da linguagem, mostrando as maneiras como ela pode significar e até antecipando o ainda não-dito;

2) a literatura não pode ser nem estudada, nem apresentada no ensino, se não for considerada como linguagem e se não for analisada como construção de sentido(s), a partir dos mecanismos lingüísticos que a constituem.

Acreditar nessas afirmações implica crer também na necessidade de promover a diluição da dicotomização língua/literatura em todos os níveis de ensino. Isso vale especialmente para os cursos de Letras, onde a língua e a literatura constituem a base da formação dos alunos, e certamente não exclui as línguas e as literaturas estrangeiras, às quais, por necessidade de currículo, é dedicado um número limitado de horas ${ }^{7}$ e para as quais, portanto, a fragmentação é ainda mais deletéria, principalmente se se leva em conta que, na maior parte dos casos, hoje como na época da criação dos primeiros cursos de Letras, os alunos iniciam a formação universitária sem conhecimentos prévios da língua e da literatura em que vão licenciar-se.

A proposta de integrar o ensino da língua estrangeira e o ensino da literatura resulta de todas essas considerações e concretamente prevê que a língua estrangeira, nesse caso a língua italiana, seja ensinada e aprendida a partir da análise de textos poéticos, que são tanto o input, a

\footnotetext{
${ }^{7}$ Vale lembrar que uma alteração no currículo do curso de Letras da USP, acontecida em 1999, reduziu de quatro para três os anos dedicados às habilitações em Línguas e Literaturas Estrangeiras e em Lingüística, já que o primeiro de ano de curso é agora considerado propedêutico e é comum a todos os alunos, que só a partir do segundo ano iniciam a habilitação escolhida.
} 
língua de partida, o insumo ${ }^{8}$, ao qual os alunos são "expostos", quanto a base das reflexões lingüísticas e de análise, que, feitas em italiano desde o primeiro momento, levam os alunos a “fazer língua”, a "produzir" em língua estrangeira.

À idéia segundo a qual o uso dos textos literários nas aulas de língua estrangeira seria desnecessário, contrapomos, então, a concepção de que o ensino da língua pode fundar-se no texto literário e considerá-lo seu núcleo central.

Nossa hipótese é que, se o ensino/aprendizagem da língua estrangeira acontece a partir do texto literário e da observação de como é construído, podem ser examinados nele os fatos gramaticais em sua funcionalidade discursiva e também os fatos literários que ajudam a reconhecer um estilo (cf. RIFFATERRE, 1989: 4). Assim, será possível perceber a relevância da função poética para o exame da função discursiva dos fatos gramaticais, que ultrapassam o limite da frase para ser vistos como fenômenos do texto e do discurso e são, portanto, essenciais para compreender tanto o "literário", quanto a complexidade da língua.

Isso já havia sido reconhecido por Jakobson, que, no ensaio anteriormente citado, mostra como uma visão lingüística de análise pode dar vida a inesperados acréscimos de significado, pelos quais se evidencia o aspecto propriamente poético (literário) dos textos e se passa da denotação à conotação, isto é, a uma ampliação dos significados possíveis dos elementos contidos nos textos.

\footnotetext{
${ }^{8}$ Para a tradução do inglês para o português do léxico específico da lingüística aplicada, como no caso do termo input (insumo) utilizado aqui, tomamos como referência o Glossário de Lingüística Aplicada elaborado por Almeida Filho e Schmitz (1998).
} 
Acontece que, por exemplo, no plano fônico, a presença de vogais abertas ou fechadas, de rimas, assonâncias ou aliterações pode indicar e recriar elementos essenciais do sentido; no plano sintático, pode-se observar o alcance de escolhas como o paralelismo ou a simetria e, no plano semântico, ver como a metáfora ou a metonímia provocam mudanças na percepção do sentido dos textos. A gramática reflete-se, portanto, na função poética e contribui para determiná-la, enquanto a função poética se revela por meio da gramática e dos recursos da linguagem, permitindo que os textos sejam "descobertos". Isso, como diz o próprio Jakobson, raramente foi considerado:

Os recursos poéticos ocultos na estrutura morfológica e sintática da linguagem, em suma, a poesia da gramática, e seu produto literário, a gramática da poesia, raramente foram reconhecidos pelos críticos e os lingüistas os negligenciaram de todo, embora fossem magistralmente dominados pelos escritores criativos. (1977: 157)

O percurso que propomos visa a pôr em relevo as características precípuas da literatura e a importância dos conhecimentos lingüísticos para a sua leitura e compreensão, de modo que a língua estrangeira, aprendida a partir da análise, prepare os alunos tanto para um aprofundamento das questões lingüísticas e das peculiaridades da língua natural da qual se aproximam, quanto para uma percepção atenta às potencialidades da língua literária e à riqueza de usos lingüísticos e de significações possíveis, que ela contém.

Para esses alunos o lingüístico e o literário, longe de ser tratados como âmbitos distantes e separados, serão unidos, de maneira que, pela língua, pela análise das manifestações lingüísticas e pela observação dos mecanismos de sua construção, eles poderão reconhecer e descobrir o poético, o literário, o estético dos textos e, pelo literário, descobrir a complexidade da língua e ter 
contato com uma "linguagem integral", para usar as palavras de Roland Barthes (2004: 5), que mostra os meandros da existência e da natureza humana.

Aprende-se a língua estrangeira e aprende-se também a "ler" literatura, a perceber como funcionam os textos literários e, a partir deles, todos os outros textos, porque a "apropriação" da língua estrangeira acontece simultaneamente à conscientização dos mecanismos por meio dos quais se realiza a produção de sentido e à reflexão sobre eles. Isso é indispensável quando se pensa no ensino de uma língua estrangeira, que - longe de reduzir-se à correção gramatical - se realiza e se completa quando, entre outras coisas, a língua é observada "em uso", para que se possa refletir sobre os elementos que a constituem e entender, nos textos e nos discursos, como eles significam.

A escolha de basear um curso de língua estrangeira em textos literários poderia ser criticada pelos que entendem que, dessa forma, seriam desconsiderados os outros gêneros e as outras manifestações da língua. No entanto, no lugar de contrapor-se aos outros gêneros, em nossa visão, o texto literário inclui os demais, ajuda a compreendê-los e pode até recriá-los, apropriando-se deles, que, lidos na perspectiva da literatura, acabam ganhando formas inesperadas. Uma notícia de jornal ou uma placa de trânsito, um diálogo cotidiano ou a descrição de uma paisagem, uma carta de amor ou a página de um diário adquirem sentidos novos e surpreendentes, quando são inseridos, por exemplo, num poema, num conto ou num romance, isto é, quando os lemos como parte de uma "escrita poética", cujas interpretações podem ir muito além daquilo que uma primeira leitura deixa entrever. 
Além disso, os mecanismos observados nos textos literários podem ser encontrados também em outros tipos de texto. Por isso, enquanto os aprendizes progridem em seu percurso de aprendizagem da língua estrangeira e da leitura e análise de textos poéticos, preparam-se também para uma relação com a leitura cada vez mais autônoma.

Nessa concepção de linguagem, de texto e de ensino, é claro que não faz mais sentido estruturar os cursos num antes e depois, em que o antes é a linguagem "comum" e o depois a linguagem literária. É por isso que, contrariamente àquilo em que muitos acreditam, consideramos que os alunos, mesmo num estágio inicial de seu processo de aprendizagem, podem "entender" os textos literários em língua estrangeira e aprender a perceber seus mecanismos de funcionamento, inclusive para que possam observar desde o começo a "nova" língua em sua "completude".

\section{A SEMIÓTICA NARRATIVA E DISCURSIVA NOENSINO DA LÍNGUAE DALITERATURA}

Para a análise dos textos literários apoiamo-nos na semiótica dita francesa, proposta por A. J. Greimas, que se constitui como uma teoria da significação, cuja primeira preocupação é explicitar "as condições da apreensão e da produção de sentido" (GREIMAS/COURTÉS, s/d: 415), de qualquer todo significante. Isso quer dizer que, ao contrário de outras semióticas, seu objeto é o texto, ou seja, os procedimentos de sua constituição. Além disso, diferentemente de outras teorias textuais, ocupa-se de toda e qualquer linguagem independentemente de sua forma de manifestação. Consideramos, por tudo isso, que a semiótica narrativa e discursiva é perfeitamente 
adequada aos nossos objetivos tanto para o ensino da língua, quanto para a análise dos textos literários.

Explicitemos um pouco melhor a questão do exame dos procedimentos do texto. A teoria busca descrever e explicar não só o que o texto diz, mas principalmente como ele diz o que diz, dando sentido aos procedimentos internos a ele, além de desvelar seu funcionamento. Em outras palavras, a semiótica ajuda a perceber como os seres humanos significam e se comunicam por meio de textos.

Isso nos permite afirmar que, na análise realizada a partir desses princípios, o texto literário não importa apenas pelo enredo ou pelo "uso exemplar" das estruturas que contém, mas, desligado do papel que tradicionalmente lhe foi atribuído nas aulas de língua estrangeira, pode realmente ser o ponto de partida para observar a língua, a "comunicação" e a construção de sentidos e pode, portanto, também ser o verdadeiro centro do processo de ensino/aprendizagem.

Vejamos como a semiótica francesa define a língua e o texto. Em primeiro lugar, a língua não é considerada como um sistema de signos, mas como "uma reunião [...] de estruturas de significação" (GREIMAS, 1976: 30). Juntas, elas constituem o texto, que é objeto de significação e objeto de comunicação entre dois sujeitos e é formado por um plano da expressão e um plano do conteúdo, ou seja, no caso de um texto verbal escrito como o texto literário, entre a "aparência" das formas lingüísticas e a "imanência" do conteúdo a que elas remetem. Além disso, o texto é considerado como um todo de significação, essa última entendida como a criação e/ou a apreensão das “diferenças”, em sentido saussuriano, isto é, como a busca de relações no interior do texto, que levam a perceber e descobrir como se chega ao sentido. 
A partir desses pressupostos, a análise semiótica visa justamente à reconstrução do sentido que resulta da reunião entre o plano de expressão e o plano do conteúdo (cf. FLOCH, 2001: 9), na observação de como ele é gerado, de como se percebem no texto as relações entre enunciado e enunciação e de como se realiza a discursivização.

Para podermos esclarecer a concepção de discurso adotada aqui, precisamos introduzir o conceito de enunciação, pois, é pela enunciação que se dá o discurso, ou seja, a passagem do sistema à história. Entendemos por enunciação uma instância pressuposta ao enunciado e que só por ele pode ser apreendida.

A enunciação implica sempre a presença de um enunciador (quem enuncia) e de um enunciatário (quem recebe a enunciação), este último, a partir de uma definição de A. Culioli (1973), também chamado de co-enunciador, para evidenciar sua posição fundamentalmente interativa $^{9}$

A enunciação é, portanto, "o ato de produção do discurso" (FIORIN, 1992: 39), de um discurso que é sempre heterogeneamente constituído e que se funda no debate com a alteridade, independentemente das marcas que indicam a presença do outro, porque toda enunciação é uma resposta a alguma coisa e é construída como resposta, em que convergem as opiniões dos interlocutores diretos e, de modo mais geral, as visões de mundo de que são portadores. O sujeito

\footnotetext{
${ }^{9}$ Embora reconheça seu papel na produção de sentido, a semiótica francesa não utiliza normalmente o termo coenunciador. Decidimos adotá-lo, por considerarmos que ele ajuda a sublinhar a participação do enunciatário na criação do sentido (ver também MAINGUENEAU, 1999: 78).
} 
acredita, ilusoriamente, ser a fonte do seu discurso, mas, na verdade, como afirma Pêcheux, “isso" fala sempre "antes, alhures e independentemente" (1975: 146).

Ora, se o texto literário é utilizado nas aulas de língua estrangeira num percurso de aprendizagem em que ele é lido e analisado, é o aprendiz que se constitui como enunciatário/coenunciador. É ele que constrói sentidos, enquanto aprende como funciona a língua e, no lugar de perceber o texto literário como algo distante e que "jamais poderá alcançar", é estimulado a criar com ele uma relação autônoma, a dialogar com ele e a construir interpretações. Além disso, se "o leitor [...] é também e, sobretudo, um 'centro de discurso', que constrói, interpreta, avalia, aprecia, compartilha ou rejeita as significações" (BERTRAND, 2003: 24), o aprendiz assume uma posição ativa e se coloca como eu em movimento e em relação não apenas com o texto, mas também com o mundo que ele representa e para o qual ele aponta.

A conseqüência é a dessacralização e a aproximação do texto literário para que possa emergir um poder-interpretar e um poder-dizer dos aprendizes que, apropriando-se do instrumental de análise, podem adquirir direito à voz e "tomar a palavra" significativamente (cf. SERRANI-INFANTE, 1998: 247). Assim, o texto literário, no lugar de identificar-se com representações de superioridade, de estaticidade e de distância da banalidade do cotidiano, que em outras épocas já incorporou, é um objeto presente, próximo e dinâmico, que amplia as possibilidades expressivas da língua, admite inúmeras interpretações, prevê rupturas, contém ambigüidades, joga com a complexidade da metáfora, diz sem dizer e não diz o que parece dizer e que, em virtude de tudo isso, se abre e se atualiza na leitura. 
A partir da análise dos fatos da gramática e dos mecanismos de construção do texto, o aluno-leitor pode descobrir o sentido e as maneiras como ele se constrói, num movimento autônomo, no qual não será obrigado a aceitar interpretações e leituras alheias, mas disporá dos instrumentos para chegar a sua própria leitura e a sua própria interpretação.

Cabe, também, acrescentar que, nesse processo, o texto literário traz, a um só tempo, prazer e conhecimento, faz refletir e provoca emoção. Por um lado, há o prazer da fruição estética do texto, mas também o prazer de descobrir o texto, de penetrar o sentido e de aprender a "ver" graças à análise, o que antes não se via; e, por outro lado, há o conhecimento porque é preciso “reconhecer que a literatura, lugar por excelência de expressão dos mitos na modernidade, é uma forma tão boa de conhecimento quanto a ciência" (FIORIN, 1996: 9), ou até superior, porque inclui a contradição humana e permite a subversão dos padrões e porque "o objeto da literatura é toda a experiência humana comunicável lingüisticamente e $[\ldots]$ a exploração dessa comunicabilidade" ${ }^{, 10}$.

E, além disso, o texto literário é conhecimento também porque está sempre ligado a um contexto, que é construção do próprio texto, e carrega consigo uma ideologia que remete a grades culturais, dialogando com muitos outros textos, situando-se, desta forma, na história e na sociedade e apontando caminhos de leitura para o complexo mundo fora dele.

Principalmente quando se aprende uma língua estrangeira, é essencial penetrar essa complexidade que é de um outro, ainda desconhecido, que ao longo da aprendizagem deve ser

\footnotetext{
10 "el objeto de la literatura es toda la experiencia humana comunicable lingüísticamente y [...] la exploración de esa comunicabilidad.” (REYES, 1984: 36).
} 
descoberto, tanto através das novas categorias constituídas pela língua, quanto por meio dos conceitos dados pela forma privilegiada de expressão que é a literatura.

De fato, percebemos o mundo com as categorias de uma língua e não podemos pensar a natureza, a vida, a cultura, a história, a não ser usando categorias lingüísticas. É por isso que aprender uma outra língua - e entrar, por meio da língua, na cultura à qual ela pertence - amplia nossos horizontes e nossa capacidade de ver o mundo porque desloca e relativiza o nosso ponto de vista.

O texto sai, portanto, fora dele, mas, ao mesmo tempo, guarda em si as condições para o seu entendimento e é, portanto, uma totalidade de sentido, já que "produz em si mesmo, ao menos parcialmente, as condições contextuais de sua leitura" e que

uma das propriedades sempre reconhecidas no texto dito 'literário' é que [...] ele incorpora seu contexto e contém em si mesmo o seu 'código semântico': ele integra assim, atualizado por seu leitor e independente das intenções de seu autor, as condições suficientes para sua legibilidade. (BERTRAND, 2003: 23)

É por isso que a semiótica não se interessa pelas condições de produção externas ao texto, que ela reconstrói, e se concentra numa análise interna (cf. BARROS, 2002: 14), a partir do próprio texto, descrevendo e explicando como ele é engendrado.

Para tanto, a teoria semiótica prevê um modelo de representação da produção de sentido dito percurso gerativo de sentido (GREIMAS/COURTÉS, s/d: 206-209), segundo o qual o sentido se constrói da imanência à aparência, da profundidade à superfície, num percurso que vai do mais 
simples e abstrato ao mais complexo e concreto, em três etapas ou níveis: o nível fundamental, o narrativo e o discursivo. Para cada uma dessas etapas há uma sintaxe (que diz respeito a operações e transformações) e uma semântica (que concerne a relações e categorias).

Vejamos, em pinceladas rápidas, as principais características do percurso. No nível fundamental, a significação revela-se como oposição semântica mínima, base de sustentação das demais etapas do percurso gerativo. A seleção de elementos recorrentes no texto permite o reconhecimento de campos semânticos e a identificação de uma oposição fundamental (ou mais de uma), a partir da idéia saussuriana de que só há sentido na diferença (SAUSSURE, 1969: 130140). Uma vez identificadas, as categorias fundamentais são determinadas como positivas (eufóricas) ou negativas (disfóricas), pela categoria tímica que opõe euforia e disforia.

A característica essencial do nível narrativo é que nele os conteúdos do nível fundamental se narrativizam por meio de "transformações" operadas pelos actantes. Os enunciados elementares representam relações e transformações e são chamados enunciados de estado ou de fazer: os enunciados de estado descrevem a relação de junção, que se materializa em conjunção e em disjunção entre sujeito e objeto, enquanto os enunciados de fazer regem os enunciados de estado e mostram as transformações, as passagens de um estado ao outro, em outras palavras, $o$ que acontece no texto (programa narrativo). Nos objetos do fazer está inscrito um valor, isto é, o significado que um objeto concreto possui para o sujeito que quer/ deve/ sabe/ pode entrar em conjunção com ele. Nas narrativas complexas dos textos, os enunciados de estado e de fazer estão organizados em quatro fases: manipulação (um sujeito age sobre outro para levá-lo a querer e/ou dever fazer), competência (o sujeito é dotado de um poder e/ou saber fazer), performance (o sujeito realiza a transformação central da narrativa) e sanção (verifica-se a realização da 
performance e o sujeito é julgado e recebe um "prêmio" se realizou a performance em conformidade com o acordo inicial e um "castigo" em caso contrário).

Passando agora ao nível discursivo, é preciso, em primeiro lugar, evidenciar que ele é o mais concreto e complexo, sendo então o mais próximo da manifestação textual, cujas estruturas produzem e organizam os significantes, definindo, no caso dos textos verbais, as particularidades das línguas naturais (cf. GREIMAS, 1975a: 126) e permitindo, portanto, que elas sejam observadas em sua diversidade.

É também no nível das estruturas discursivas que são recuperados elementos da enunciação e são estudadas suas relações com o enunciado, essenciais para não perder aspectos da significação do discurso, que são particularmente relevantes quando se analisam textos literários, os quais, para serem lidos em sua complexidade, precisam ser vistos como enunciação e produção e não apenas como enunciado e como produto.

Para entender o processo de discursivização é necessário compreender os mecanismos de temporalização, de espacialização e de actorialização (cf. FIORIN, 1996a: 15), isto é, da projeção no enunciado pela instância da enunciação de tempo, espaço e pessoa. Isso se realiza por meio das operações de debreagem e embreagem, que podem ser temporais, espaciais e actanciais.

A debreagem "expulsa" pessoa, tempo e espaço para fora do ato de enunciação, criando um não-eu (um ele diferente do sujeito da enunciação), um não-agora (um então diferente do tempo da enunciação) e um não-aqui (um algures ou alhures diferente do lugar da enunciação), que podem manifestar-se por um eu, um aqui e um agora (debreagem enunciativa) ou por um ele, um 
alhures e um então (debreagem enunciva). A embreagem, ao contrário, é o "efeito de retorno à enunciação" (GREIMAS/COURTÉS, s/d: 140), sempre posterior a uma debreagem, e visa, entre outras coisas, a criar a neutralização entre os elementos da categoria de pessoa, de espaço e de tempo. Debreagens e embreagens produzem efeitos de realidade e de verdade.

Fundamental é não esquecer que o eu, o aqui e o agora do texto são sempre simulacros e que não correspondem ao produtor do texto, a seu tempo e a seu espaço. É por isso que usamos o conceito de enunciador ou sujeito da enunciação, que coloca no mundo do enunciado as marcas da enunciação.

A actorialização instaura a pessoa e regula a questão do ator e sua relação com o discurso. $\mathrm{O}$ ator é efeito de construção do próprio discurso e apóia-se no actante, que é uma abstração narrativa do ator individualizado e figurativizado e que possui caráter formal anterior a qualquer investimento semântico. O termo ator substitui o termo personagem, visando à possibilidade de uma maior precisão e generalização e, ao mesmo tempo, permitindo seu uso fora da linguagem estritamente literária (GREIMAS/COURTÉS, s/d: 34).

A temporalização instaura o tempo no enunciado e toma como momento de referência o momento da enunciação, a partir do qual se estabelecem as oposições temporais da língua. Além disso, o tempo lingüístico está relacionado à ordenação dos estados e das transformações narrados no texto. Existem então dois sistemas temporais: um relacionado diretamente ao momento da enunciação (sistema enunciativo) e outro ordenado em função de momentos de referência instalados no enunciado (sistema enuncivo). O momento de referência está relacionado ao momento da enunciação e, aplicando a este último a categoria topológica concomitância vs 
não-concomitância (anterioridade vs posterioridade), obtemos três momentos de referência: um concomitante ao momento da enunciação, que é o tempo do "olhar" (sistema enunciativo); um outro anterior, que é o tempo da "memória" (subsistema enuncivo do pretérito); e um terceiro posterior, que é o tempo da "espera" (subsistema enuncivo do futuro) ${ }^{11}$. Temos então um sistema enunciativo e dois subsistemas enuncivos, a partir dos quais se constroem as referências e as relações temporais estabelecidas entre os acontecimentos.

A espacialização instaura no enunciado um espaço, sempre determinado em função do hic, do aqui, que é implícito em qualquer enunciado, mas que pode também ser explicitado. É em função desse hic, que se determinam o algures (em algum lugar) ou o alhures (em outro lugar), bem como o aí, o ali e o lá.

Também para criar um efeito de realidade quanto a pessoa, tempo e espaço, eles são figurativizados e ancorados na "história" por meio de antropônimos, cronônimos e topônimos, que "dão nomes" a atores, momentos e lugares.

Ainda relativamente a pessoa, tempo e espaço, é preciso acrescentar que os percursos de discursivização permitem focalizar uma outra questão: a do ponto de vista do observador, que “aspectualiza" tempo, espaço e atores.

No que concerne ao tempo, as categorias concomitância vs não-concomitância e anterioridade vs posterioridade serão substituídas pelas categorias permanência vs incidência $\mathrm{e}$

\footnotetext{
${ }^{11}$ Santo Agostinho considerava inexato falar de passado, presente e futuro e julgava que temos, na verdade, três modalidades de presente: a "memória" é o presente do passado; o "olhar", a "visão" é o presente do presente; a "espera" é o presente do futuro (cf. FIORIN, 1996: 132).
} 
continuidade vs descontinuidade, de maneira que o observador possa "ver a cena" no seu aspecto durativo (continuidade, permanência) ou como um ponto, algo acabado (descontinuidade, incidência). Um processo durativo pode ainda ser visto em seu início (aspecto incoativo), em sua realização (aspecto cursivo ou progressivo) e em seu término (aspecto terminativo). O tempo pode também ser considerado do ponto de vista quantitativo (meses, dias, horas, etc.) e qualitativo (rápido e lento em relação a uma referência).

No espaço o enunciador escolhe o ponto de vista de um observador, por meio do qual impõe uma perspectiva e manipula o enunciatário, convidando-o a "olhar" a partir do alto, de uma posição de superatividade, ou do baixo, de uma posição de inferatividade e determinando uma específica direcionalidade e, do mesmo modo, estabelecendo o que está próximo e o que está longínquo.

Actorialização, temporalização e espacialização são, como vimos, categorias que estabelecem relações, importantes para "garimpar" a forma do conteúdo do texto. Foi por isso e foi também considerando que cada língua natural as manifesta de formas diferentes, que decidimos dar ênfase em nossas análises e, principalmente, nas atividades didáticas ao nível discursivo e aos mecanismos de discursivização. Para sua depreensão é indispensável conhecer e saber interpretar os recursos verbais e os fatos gramaticais, os quais adquirem sentido nas relações reconhecidas nos textos e nos discursos, levando, por sua vez, a descobrir como se realiza a significação.

Antes de terminar essa breve descrição do percurso gerativo de sentido, é preciso lembrar mais dois procedimentos que pertencem ainda ao nível discursivo. Trata-se da tematização e da 
figurativização, que instalam no texto temas e figuras, sempre interligados entre si, criando percursos temáticos e figurativos, por meio dos quais podemos reconhecer de que trata um texto, conseguindo assim passar da figura ao tema. Isso nos pode guiar na leitura e na interpretação do texto, permitindo que reconheçamos também a manifestação ideológica do discurso.

Um texto que use principalmente termos concretos (figuras) vai ser considerado figurativo, enquanto um texto no qual apareçam coisas, idéias e conceitos, que não fazem parte da realidade concreta, mas a categorizam (temas) vai ser chamado temático. Os textos diferenciam-se pelo maior ou menos grau de concretude, mas nenhum deles é exclusivamente temático ou exclusivamente figurativo (cf. FIORIN, 1996: 23-25). Os textos literários possuem a característica de ser mais figurativos e "[...] a figuratividade faz surgir aos olhos do leitor a 'aparência' do mundo sensível” (BERTRAND, 2003: 21).

Ligada à tematização e à figurativização está ainda a questão da coerência textual, que é dada pelas isotopias temáticas e figurativas, reconhecíveis a partir de recorrências no discurso de temas e figuras, que se apóiam na análise sêmica e designam a iteração de semas ao longo de uma cadeia sintagmática.

Terminamos aqui nossa breve descrição de alguns dos conceitos fundamentais da semiótica, que, na análise dos textos literários, podem ajudar a descobrir o funcionamento dos textos e dos discursos e contribuir para que se possa adquirir consciência dos efeitos de sentido criados na linguagem, estudar as relações entre enunciado e enunciação e aprender a explicitar os mecanismos intra e interdiscursivos de constituição do sentido do texto. 
Utilizar essa perspectiva num curso de língua estrangeira significa dar atenção às maneiras como se dá o sentido, às "regras" que regulam o discurso e à funcionalidade discursiva dos fatos gramaticais da língua que os alunos estão aprendendo e permite que eles adquiram, ao longo do processo de aprendizagem, a sensibilidade necessária para ler para além da aparência dos textos.

Nossa convicção é que esse movimento, se realizado com textos poéticos, isto é, com a língua em sua "funcionalidade plena", garante uma expansão das potencialidades receptivas e produtivas dos aprendizes, a qual acompanha a multiplicidade e a plurissignificação da linguagem literária, melhorando o desempenho no que concerne à compreensão e à produção de textos em língua estrangeira, bem como à compreensão deste fato lingüístico singular, que é a literatura. Essa é nossa crença íntima. É preciso, no entanto, comprová-la. É o que pretende fazer esta tese. Ela será, portanto, conduzida pelas seguintes questões: a união dos estudos de língua e de literatura baseada na análise do texto literário é eficaz no ensino/aprendizagem de língua estrangeira? É possível ensinar uma língua estrangeira utilizando textos literários desde o início do processo de ensino/aprendizagem e sem passar pela linguagem "comum"? Ou é necessário preparar os alunos e introduzir a literatura só quando eles “dominam” a língua estrangeira?

Nesse percurso os alunos serão participantes ativos de seu processo de aprendizagem e, no contato com os textos literários assim vistos, poderão preparar-se para a complexidade que é a expressão lingüística em todas suas manifestações, na língua materna e na língua estrangeira, já que a literatura, enquanto forma privilegiada de expressão, poderá orientá-los num percurso múltiplo, projetado em várias direções, que garante uma formação completa e não fragmentária porque une e não separa, porque descobre confluências e não divisões. 
Isso se torna especialmente importante se o objetivo é preparar os alunos para a autonomia necessária na vida além e depois da "escola", ainda mais, se esses alunos serão profissionais das Letras, precisando aguçar seus sentidos em relação à linguagem, aos textos e aos discursos.

\section{OCURSO EXPERIMENTAL}

Com a finalidade de alcançar os objetivos expostos, foi planejado e implementado nas disciplinas obrigatórias de Língua Italiana um curso experimental com a duração de seis semestres, realizado no período de 2004 a 2006, para as duas turmas paralelas (matutino e noturno) da habilitação em Língua e Literatura Italiana do curso de Letras da Faculdade de Filosofia, Letras e Ciências Humanas da Universidade de São Paulo, que iniciaram sua habilitação naquele ano sem nenhum conhecimento prévio de italiano e que o estudaram, em geral, apenas em nosso curso. Para cada semestre dispúnhamos de quatro horas de aula por semana e de um mínimo de 15 semanas, de modo a perfazer um total de cerca de 60 horas por semestre. As horas de aula foram sempre quatro por semana, divididas em dois encontros e a média de alunos por turma ficou em todos os semestres entre 30 e 35 .

No curso procuramos pôr em prática nossa idéia de junção entre o ensino da língua e da literatura estrangeira, realizando-a por meio da análise semiótica de textos poéticos. Os textos poéticos ou artísticos (principalmente literatura, mas também cinema e canções) eram o único input utilizado e não havia um livro didático utilizado em paralelo. Explicaremos mais detidamente no capítulo 2 qual era o tipo de tratamento reservado à gramática, que, sempre vista 
em sua funcionalidade discursiva, não guiava a progressão das aulas, sendo, ao contrário, introduzida quando os textos e as necessidades expressivas dos alunos pediam. No entanto, havia também aulas de gramática explícita e foram indicados aos alunos "exercícios" não obrigatórios que eles poderiam fazer autonomamente fora do horário de aula.

Como dissemos, os textos escolhidos para o curso foram, em primeiro lugar, textos literários, embora tenhamos, ainda que em menor medida, utilizado também músicas e trechos de filmes, cujo sincretismo de linguagens acrescenta elementos a partir dos quais reconstruir o(s) sentido(s). Ao componente verbal das músicas e dos filmes foi dedicada especial atenção, mas o plano sonoro das músicas e os planos sonoro e visual dos filmes também foram objeto de reflexão, já que contribuem de forma essencial para a construção do sentido e para os efeitos de sentido que os textos manifestam.

A hipótese que nos guiou nessa escolha de incluir textos artísticos não só estritamente literários é que todos eles são "poéticos", isto é, possuem uma função estética. A idéia é, em suma, ver a arte como mimesis, ou seja, imitação e representação da realidade, e, portanto, como poiesis, isto é, como criação e transformação da mesma realidade. Se, como escreveu Antonio Candido, “[...] a mímese é sempre uma forma de poiese” (1975: 12), todos os textos que representam a realidade são expressões de um modo de ver aqueles fatos e aquelas situações e justificam, portanto, análises e interpretações.

Quanto aos textos literários, procuramos alterná-los por gêneros ao longo do curso, distinguindo-os conforme privilegiavam embreagens ou debreagens (cf. BERTRAND, 2003: 94), a dimensão enunciativa ou a enunciva. Em especial, consideramos relevante, para as finalidades a 
que o curso visava, a distinção entre o monólogo lírico da poesia, regido pelo discurso debreado enunciativamente e, portanto, dominado pela presença de um eu explícito, e os gêneros narrativos, nos quais prevalece o discurso debreado enuncivamente e a terceira pessoa que esconde o eu por meio do ele, da "não-pessoa" (BENVENISTE, 2005: 251).

Procuramos, na seleção dos textos, destacar a literatura contemporânea, dando espaço especialmente aos escritores menos conhecidos pelos alunos e àqueles que não fazem parte do percurso canônico das disciplinas de Literatura Italiana. O objetivo foi, entre outros, o de apresentar, por meio da produção literária mais recente, a língua de hoje e o mundo, a cultura, a sociedade e a ideologia para os quais os textos apontam, para que os discentes pudessem ter contato com a Itália contemporânea.

Outro critério que teve peso na escolha dos textos foi sua brevidade. Por isso, trabalhamos principalmente com contos e poemas, os quais constituem uma unidade em si, que não precisa ser recortada de uma obra maior, preservando, dessa forma, sua totalidade de sentido. Textos breves permitem também, que, ao longo do trabalho de análise, os alunos voltem facilmente a eles, sem perder a visão do conjunto, propiciando uma espécie de gradativa "apropriação" do texto, pois a cada leitura podem ser notados aspectos que não haviam sido percebidos anteriormente.

Na estruturação do curso guiou-nos a convicção de que, em razão da complexidade tanto do processo de aquisição/aprendizagem ${ }^{12}$ de uma língua estrangeira, quanto da prática de análise de

\footnotetext{
12 Durante muito tempo procurou-se distinguir entre os termos aquisição e aprendizagem, entendendo-se por aquisição a interiorização e "assimilação" implícita da língua e por aprendizagem o estudo formal que leva ao conhecimento explícito de "regras", sem necessariamente implicar que se saiba usar a língua (KRASHEN, 1981). Mais tarde ficou claro que não havia uma tão clara separação entre os dois fenômenos e que era perfeitamente possível que
} 
textos poéticos, não há um único "método" que possa ser visto como sempre válido e aplicável e de que há teorias que podem conviver, sem eliminar-se reciprocamente.

Em especial, nos últimos desenvolvimentos das reflexões sobre ensino/aprendizagem de línguas estrangeiras, não são raros sinais da insuficiência das teorias e dos modelos existentes. Assim, por um lado, há especialistas e pesquisadores que chegaram a procurar em teorias como a do caos (cf. LARSEN-FreEMAN, 1997; PAIVA, 2005) uma resposta que pudesse contemplar os processos e os fatores envolvidos nesse fenômeno, que varia de pessoa para pessoa, de situação para situação, de momento para momento; e, por outro, há estudiosos que proclamam o fim do "método".

C'era una volta il metodo [Era uma vez o método] diz, de fato, o significativo título do livro organizado por Carlo Serra Borneto e publicado na Itália em 1998, que trata justamente da impossibilidade de definir e adotar uma única metodologia de ensino ou de identificar "melhores" ou "piores" maneiras de organizar o trabalho na sala de aula de língua estrangeira. O que importa é conhecer, refletir, pesquisar e ter consciência do papel do professor e do aprendiz, já que crenças novas e antigas se misturam, convivem e, em alguns casos, se alternam.

Mais do que "métodos", haverá, então, hipóteses e propostas a orientar nosso trabalho e nossa prática em sala de aula, a partir da concepção de língua e de ensino, que guia nossa reflexão.

se passasse da primeira à segunda forma de relação com a língua estrangeira e vice-versa. É por isso que decidimos usar aqui ambos os substantivos, separados por uma barra para indicar a coexistência dos processos. Voltaremos a esse assunto no capítulo 2. 
A proposta de currículo multidimensional formulada por Serrani (2005) foi uma das referências, porque, partindo de uma visão discursiva de língua, procura dar conta do complexo. Sua idéia baseia-se no modelo multidimensional de Stern (1992), que já havia imaginado ao menos quatro aspectos que é necessário levar em conta no ensino de línguas e na organização dos currículos: língua, cultura, comunicação e tomada de consciência da linguagem.

Serrani apóia-se nesse modelo e modifica-o incluindo a concepção de discurso e criando um percurso de ensino formado por três componentes: intercultural, de língua-discurso e de práticas verbais. Nele sua preocupação principal é com a dimensão enunciativo-discursiva da linguagem, que supera a descontextualização e as limitações observadas em livros didáticos, para ampliar as finalidades educativas dos currículos para o ensino de línguas.

Assim, a língua não é apenas um meio, um instrumento, mas aquilo que de fato "faz" o ser humano, pois permite que o sujeito esteja inserido no mundo e, portanto, ligado à cultura, à história, à sociedade, à ideologia.

Além disso, conceitos essenciais que nos acompanharam nas escolhas didáticas foram os de centralidade do aluno, de construção autônoma do conhecimento para o desenvolvimento da independência do aprendiz e de tomada de consciência do alcance e dos mecanismos da língua que nunca é ingênua e que "funciona para comunicar". "Comunicar" não significa aqui apenas transmitir uma mensagem utilitária e cotidiana e conseguir realizar um objetivo concreto, mas sim saber que por meio da linguagem podemos convencer, persuadir, manifestar opiniões, expressar concepções de mundo e posicionar-nos de várias maneiras em relação a ele e aos nossos interlocutores-leitores-ouvintes e que tudo isso acontece na e pela língua não só porque 
sabemos usar corretamente sua gramática, seu léxico e suas estruturas, mas também porque temos consciência de nossas escolhas e de seu sentido.

Esses conceitos deixam transparecer que, embora tenhamos optado por não problematizá-la mais detidamente ao longo da tese, nossa hipótese pedagógica de base remete às idéias cognitivoconstrutivistas de origem vigotskiana, que enfatizam o papel do aprendiz, em primeiro lugar, porque a aprendizagem só pode realizar-se se ele estiver preparado para receber o conhecimento e, em segundo lugar, porque é a partir do próprio aprendiz e dos assuntos "importantes" para ele que o conhecimento se constrói.

Isso não significa que a aprendizagem funcione só se for baseada em assuntos fáceis ou próximos dos discentes. Ao contrário, estes serão estimulados pelo insumo (input) complexo, porque corresponde às condições "naturais" de aprendizagem e cria, portanto, a instabilidade, a partir da qual será possível a recomposição num nível superior de organização.

Daí a importância de usar textos "autênticos", isto é, textos - como os literários - que não são criados especificamente para o ensino da língua estrangeira, nem adaptados para esse fim, eliminando eventuais dificuldades para os aprendizes (estruturas gramaticais ainda não conhecidas; léxico julgado "difícil"; sintaxe complexa) ou evidenciando, por exemplo por meio da repetição, um determinado aspecto lingüístico que se quer apresentar (ver, entre outros, FRANZONI, 1992: 41-57).

Além disso, nessa concepção de ensino/aprendizagem é essencial o componente "social" e o saber será, portanto, compartilhado e criado de forma colaborativa entre os alunos para os quais 
o docente será um "facilitador" que não propõe conhecimentos pré-fabricados, mas procura favorecer os discentes e fornecer suporte e instrumentos para que eles possam elaborar hipóteses próprias, verificá-las e assim desenvolver seu conhecimento ${ }^{13}$.

\section{PlanodateSE}

Com o objetivo de esclarecer qual foi o tratamento dado aos textos literários no percurso de ensino/aprendizagem planejado, mostraremos, ao longo da tese, os principais passos do trabalho realizado.

Apresentaremos, para esse fim, seis textos literários, escolhidos entre os que foram utilizados no nosso curso experimental (entre quatro e seis por semestre). Selecionamos um texto para cada um dos seis semestres que compuseram o curso e teremos, portanto, três contos e três poemas; aqueles analisados com os alunos nos semestres ímpares (no primeiro, terceiro e quinto) e estes nos semestres pares (no segundo, quarto e sexto).

Iniciaremos pelas nossas análises dos textos, já que, após a seleção dos textos, era essa a primeira fase do trabalho. Por meio das análises podemos perceber como a semiótica pode aumentar a inteligibilidade dos textos e evidenciar caminhos para chegar ao sentido.

\footnotetext{
${ }^{13}$ Para as relações do construtivismo com a didática das línguas estrangeiras, ver, entre outros, WOLFF (1994) e, em especial, O’MALLEY/CHAMOT (1990).
} 
Também observaremos nas análises como o plano da expressão e os instrumentos dos quais dispõe recriam em si o conteúdo, como os fatos da gramática contribuem para a conotação, isto é, criam novos significados e produzem efeitos de sentido; como os textos são prolíferos em metáforas, metonímias e formas de expressão que superam os limites da frase e sugerem associações em nível de texto e de discurso; como os fatos da sintaxe da frase também contribuem para esse efeito de conotação; como o uso de conectores argumentativos, entre os quais, por exemplo, o "mas" (que veremos na análise do primeiro conto e do primeiro poema) pode inaugurar novos paradigmas interpretativos; como os fatos da gramática da frase confirmam a depreensão da função poética dos textos, cujo sentido é construído numa análise que observa as peculiaridades do percurso gerativo de sentido, assim como é proposto pela teoria semiótica. As análises dos textos literários permitirão reconhecer que o trânsito entre a língua e a literatura e entre os estudos lingüísticos e os estudos literários mostra superposições, coincidências e analogias, muito mais que diferenças, evidenciando na prática as razões que nos levam a acreditar na real possibilidade de um ensino integrado. [Capítulo 1]

Em seguida, passaremos à descrição das atividades didáticas, que foram desenvolvidas a partir dos textos literários escolhidos e das análises semióticas feitas. Os aspectos peculiares dos textos, que as análises revelaram, foram utilizados nas atividades didáticas, de modo a indicar aos alunos possíveis percursos significativos, ditados pelos próprios textos e evidenciados através da análise. Como veremos, as atividades realizadas em sala de aula tinham o objetivo de contribuir para o desenvolvimento tanto de competências na língua estrangeira, quanto de competências na análise dos textos literários. Explicaremos com base em que estudos de ensino/aprendizagem de línguas estrangeiras elas foram criadas e deter-nos-emos especificamente nas atividades didáticas referentes aos seis textos anteriormente apresentados, para que se possa perceber de que maneira 
o texto e as análises acabaram transformando-se em "material didático" para a sala de aula. Discutiremos nesse capítulo também como foi organizado o currículo do curso experimental e quais foram as teorias a partir das quais se iniciou a reflexão sobre o que é necessário levar em conta na hora da programação. [Capítulo 2]

O último capítulo conterá a avaliação de uma seleção das produções escritas, redigidas pelos alunos que participaram do curso experimental. No caso das produções dos alunos, também utilizamos aquelas que se referem aos seis textos literários, já vistos como ponto de partida de nossas análises semióticas e como base para as atividades que constituíram seu elemento central. As redações foram escritas pelos alunos sempre após um dos ciclos de aulas, durante as quais era analisado o texto literário. Cabe dizer que essa atividade de produção escrita não era executada no horário das aulas do curso e que isso, além de ser motivado pelo tempo limitado a nossa disposição, foi feito também com o objetivo de deixar que o trabalho de redação acontecesse no tempo e no espaço determinados pelos discentes, de maneira a poder incentivar sua vivência individual com os textos literários propostos.

Para cada aluno, levamos em conta uma produção escrita por semestre, perfazendo um total de seis produções por aluno. Essas produções escritas foram observadas com dois objetivos diferentes: por um lado, examinar o desenvolvimento lingüístico e, por outro lado, o refinamento na capacidade de análise dos textos literários.

Para tanto, avaliamos às redações segundo os princípios de fluência, precisão, complexidade, variação lexical (fluency, accuracy, complexity, lexical variation), critérios, já utilizados em inúmeras pesquisas desde os anos 70, que o estudo de Wolfe-Quintero et alii 
(1998) procurou sistematizar. O objetivo foi perceber, por meio dos resultados obtidos, de que maneira se modificou a interlíngua ${ }^{14}$ dos alunos, que tipo de progressos lingüísticos é possível observar e se há regularidades significativas.

As redações foram também avaliadas para perceber se e como progrediu a capacidade de análise dos alunos e, para alcançar esse objetivo, foram lidas para que pudéssemos buscar nelas recorrências e diferenças, ao longo do tempo, quanto à identificação, em relação aos textos literários analisados, de elementos relativos à análise dos procedimentos de discursivização. Referimo-nos principalmente às categorias de tempo, espaço e pessoa e procuramos identificar nas produções dos alunos se e como eles iam desenvolvendo competências quanto à percepção dos efeitos de sentido e à interpretação. Consideramos que o tratamento dado pelos alunos a esses aspectos dos textos pode ser utilizado como sinal da transformação de sua relação com os textos e de sua capacidade de perceber como os textos produzem sentido. [Capítulo 3].

\footnotetext{
${ }^{14}$ Utilizamos aqui o conceito de interlíngua, conforme a definição desenvolvida a partir de Selinker $(1969,1972)$, segundo a qual interlíngua não é um conjunto de "erros" isolados, mas um sistema autônomo em movimento e em construção, que se desenvolve a partir das hipóteses feitas pelos aprendizes ao longo de sua aprendizagem e de seu percurso da língua materna à língua alvo. O que interessa não é apenas a "proficiência", isto é, a capacidade de os alunos excluírem "agramaticalidades" (embora esse ainda seja um dos objetivos), mas sim observar o desenvolvimento de seu sistema lingüístico (cf. também PALLOTTI, 1998: 21-106).
} 


\section{TEXTOS LITERÁRIOS PARA O ENSINO DO ITALIANO COMO LÍNGUA ESTRANGEIRA: UMA ANÁLISE SEMIÓTICA}

Passemos agora à análise semiótica dos textos que foram utilizados em sala de aula. Como dissemos, trata-se de três contos e três poemas, que foram alternados nos seis semestres de curso. Para termos clareza sobre a maneira como procedemos no trabalho, ressaltamos que as análises que seguem não foram elaboradas com o objetivo de serem levadas prontas para a sala de aula. Os textos eram analisados antes, para que pudessem ser evidenciados neles aspectos significativos que serviriam como base para a posterior elaboração das atividades didáticas.

\subsection{OsCONTOS}

Os três contos escolhidos para a análise e o trabalho em sala de aula fazem parte de uma coletânea do escritor italiano Gabriele Romagnoli, publicada em 1993 e intitulada Navi in bottiglia [Navios em garrafa]. No ano da primeira edição dos contos, o livro do Romagnoli foi finalista do prêmio literário Campiello e, no ano de 2000, o escritor começou a publicar uma seleção dos mesmos contos, já em circulação nas livrarias, no jornal italiano La Repubblica, para o qual continua até hoje a escrever novos textos com características parecidas às dos primeiros.

Trata-se de contos breves, tão breves que foram denominados 'microracconti' ('microcontos’). Na capa da edição da qual foram extraídos (que reproduzimos a seguir) eles são apresentados com estas palavras: "Questi sono racconti di trenta righe, ma se avete paura della vita fermatevi alla ventinovesima..." ["Estes são contos de trinta linhas, mas se vocês têm medo 
da vida, parem na vigésima nona...”]. O texto é assinado por Gabriele Romagnoli, cujo nome já aparece uma primeira vez na parte superior da capa, em grandes letras brancas com fundo preto, que lhe dão destaque especial. O nome é seguido pelo título do livro e pela descrição dos contos acima citada, que é - como dissemos - assinada por ele. Podemos, portanto, reconhecer estratégias que procuram conferir ao nome, apresentado como o do autor, um alto grau de iconização que contribui para a construção da figura de um 'fiador ético'15. Ele deve responsabilizar-se pela confiabilidade e pela verossimilhança do que o co-enunciador está prestes a ler e predispõe o público, desta maneira, antes mesmo que inicie o contato com os textos, à adesão. Observando a capa do livro, descobrimos que as estratégias utilizadas para conquistar o leitor não terminam aí:

15 O conceito de 'fiador ético' ou simplesmente 'fiador' é oriundo dos estudos sobre éthos de Dominique Maingueneau. Em ‘Éthos, cenografia, incorporação’. In: AMOSSY, 1999: 69-92. 
Gabriele Romagnoli - NAVI IN BOTTIGLIA [NAVIOS EM GARRAFA]

Estes são contos de trinta linhas, mas se vocês têm medo da vida, parem na vigésima nona...

Gabriele Romagnoli

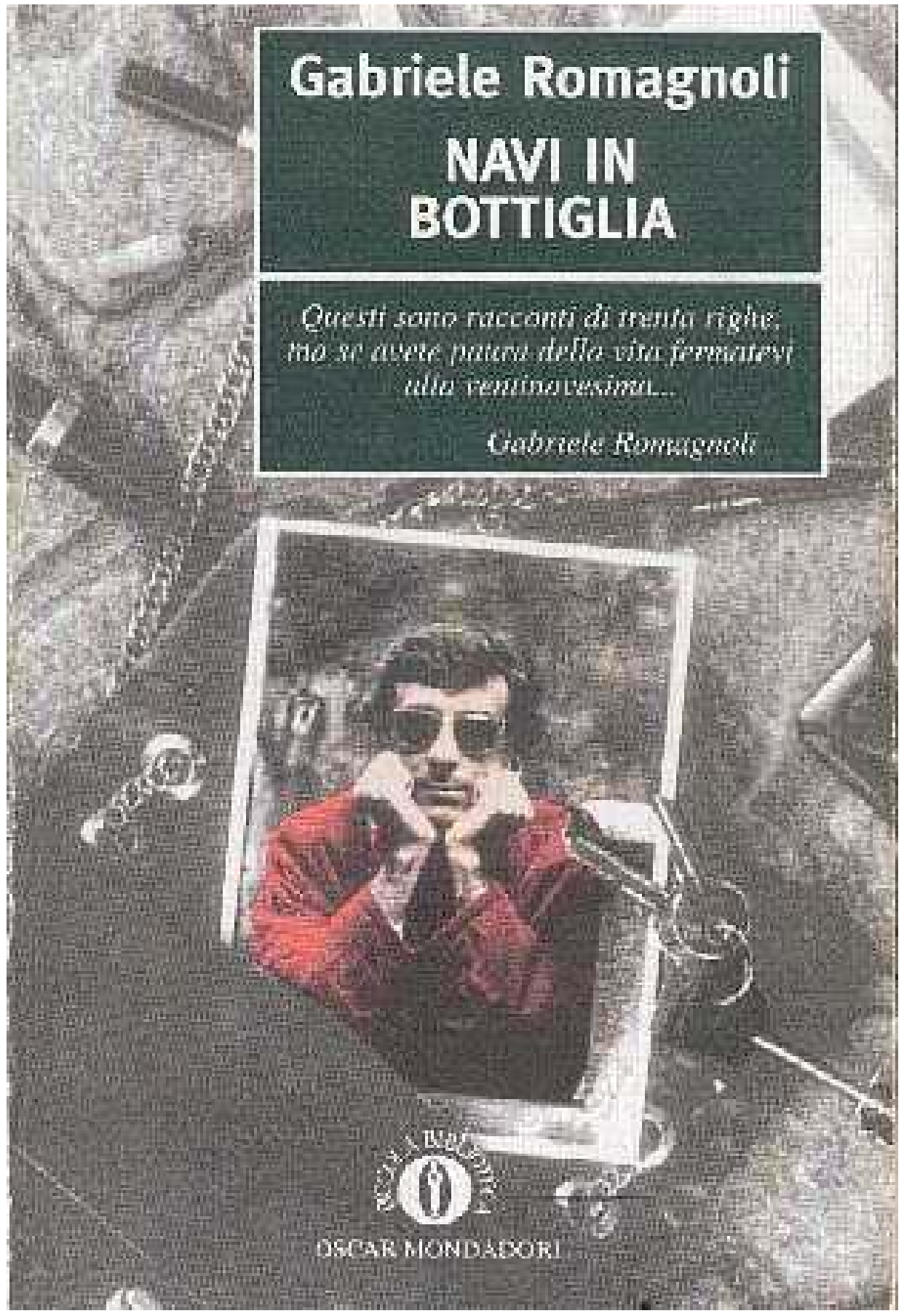


O dêitico espacial enunciativo "estes", com o qual começa a definição, cria um primeiro efeito de sentido de "realidade" remetendo ao "texto" como objeto, que o enunciatário provavelmente tem em mãos, enquanto lê. O enunciador inscreve, portanto, os contos na cena enunciativa, de que ele e o enunciatário fazem parte, estabelecendo desta forma uma primeira ligação com ele. O eu instalado no enunciado por meio do "vocês" (voi, no original italiano) configura um ator da enunciação, que "assume a responsabilidade" pelo que escreve e se posiciona em relação ao enunciatário, criando a ilusão referencial da fala em presença.

O enunciador diz que o livro contém "contos de trinta linhas" e o co-enunciador pode, abrindo o livro e olhando os textos, facilmente verificar essa informação. Mais difícil será verificar se realmente a trigésima linha contém o que dá "medo da vida", porque para isso ele precisa não ter medo. No artigo "Algumas considerações sobre o medo e a vergonha", Fiorin diz:

há dois tipos de medo: um derivado da possibilidade de uma sanção pragmática negativa (medo dissuasório) e outro de uma performance vista como ameaçadora (1992b: 57).

Por um lado, então, a sanção pragmática negativa (punição), e, por outro lado, a performance vista como ameaçadora, porque se refere ao saber o que o outro pode fazer, em sendo este fazer uma conjunção com algo disfórico (medo do outro). O medo de que fala o enunciador, apresentando os contos, não é medo de uma sanção pragmática negativa. É medo de uma conjunção com um "saber" disfórico, que pode provir da leitura dos contos, que o mesmo enunciador quer "aparentemente" evitar que o enunciatário realize. A frase "se vocês têm medo 
da vida, parem [...]" parece justamente convidar à não-leitura, parece que o enunciador modaliza o enunciatário pelo não querer, para que não queira ler os contos.

O convite a não ler existe, contudo, apenas no modo da mentira, porque parece, mas não é. O mecanismo que se instaura é o mesmo dos filmes e livros de terror ou de suspense: o enunciatário sabe que terá "medo" e isso acaba transformando-se numa manipulação por provocação, que, ao contrário, provoca no enunciatário um querer ler que é conseqüência de um querer ser: ele quer ser "impávido" (aquele que não tem ou não trai nenhum medo), "intrépido" (aquele que sabe do perigo, mas afronta-o sem medo) ou "corajoso" (aquele que sabe do perigo, tem medo, mas enfrenta-o mesmo assim) ${ }^{16}$ e, portanto, quer ler os contos.

Outro aspecto que vale a pena sublinhar é que uma definição prévia dos contos estabelece, antes mesmo que se abra o livro, uma espécie de "coerção de gênero": a trigésima linha deve conter um elemento de choque, algo que faça ter medo da vida, do outro que faz entrar em conjunção com algo disfórico.

Se o todo está nas partes, a leitura da apresentação desses contos na capa do livro já justifica algumas hipóteses quanto ao éthos do enunciador e ao seu estilo. Embora ele não diga nada sobre si mesmo ${ }^{17}$, temos indicadores da sua voz, da sua corporalidade, da sua maneira de ocupar o mundo. De fato, um enunciador que se refere ao "medo da vida" para apresentar a sua narrativa deixa prever um éthos impávido e temerário, cujo simulacro é de não ter ou não trair

\footnotetext{
${ }^{16}$ Para essas definições apoiamo-nos de novo em FIORIN, 1992b: 58.

${ }^{17}$ Como lemos em Maingueneau (1997: 45), a dimensão do éthos era bem conhecida já na retórica antiga, que entendia por éthé "as propriedades que os oradores se conferiam implicitamente, através de sua maneira de dizer: não o que diziam a propósito deles mesmos, mas o que revelavam pelo próprio modo de se expressarem."
} 
medo da vida e de observá-la de fora, enquanto ela acontece, provavelmente como algo que não pode mudar. E o éthos de observador impassível é confirmado também pela imagem da capa do livro.

A capa é um texto sincrético que joga com a fotografia e as palavras. O fundo é preto e branco e no meio está uma fotografia, que somos levados a crer que represente o autor, mesmo porque seu nome, como já dissemos, aparece duas vezes na capa. A fotografia contribui para criar um efeito de "carnalidade" para o enunciador, construir a ilusão de que é ele quem fala e mostrá-lo como fiador ético, que garante a "verdade" de tudo o que diz e, por isso, faz crer (persuasão). Ele aparece com o queixo apoiado sobre as mãos fechadas, uma expressão séria do rosto, óculos escuros de quem vê sem ser visto. O homem da fotografia veste um casaco vermelho, que é o único objeto colorido da capa. À cor vermelha do casaco pode-se associar a idéia do sangue, evocada pelas palavras acima da sua cabeça ("paura della vita", "medo da vida"), embora essa cor seja pródiga de associações, entre elas a paixão. À primeira vista a foto domina a "cena", mas olhando com mais atenção percebemos que ela está saindo de um objeto preto e com uma corrente, que parece ser a bolsa de uma mulher, caída no chão da rua de uma cidade (como se intui pelo tipo de pavimentação), da qual saíram, além da fotografia, outros objetos. Há entre eles chaves de casa com um chaveiro, batom, lápis de maquiagem e uma folha de papel. Vemos também uma ponta de cigarro de alguém que provavelmente fumou na rua e apagou o cigarro, no chão. A bolsa, caída e aberta, também no chão, parece ter sido puxada, talvez com violência, como se a mulher que a carregava tivesse sido assaltada ou tivesse sido surpreendida por algo que a fez correr. Os objetos constroem uma cena de vida cotidiana, são objetos que se carregam todos os dias e que não revelam nada de especial. Assim como as 
histórias contadas que são histórias comuns, mas escondem sempre algo surpreendente, além de revelar o caos que é a vida.

Cria-se um efeito de sentido de desordem pela disposição dos objetos no chão e não estão em linha reta na capa nem a fotografia, nem a bolsa. As linhas são oblíquas e, além disso, o retângulo da fotografia que aparece saindo da bolsa não é fechado, contribuindo para a criação do efeito de sentido de incompletude e de desordem. Retas são, ao contrário, as linhas da caixa de texto na qual estão as palavras que apresentam os contos, como se as palavras e o contar pudessem organizar o caos.

Considerados como totalidade (DISCINI, 2003:31-36), os três textos fornecem outros elementos que contribuem para definir a voz, o caráter, o corpo do ator da enunciação. Aliás, voz e corpo estão muito presentes nos textos e na maneira como eles são construídos. É a corporalidade dos atores do enunciado que é construída no modo do parecer e do ser, como um simulacro de verdade.

Embora aparentemente diferentes quanto aos temas tratados, os três contos que analisaremos têm certamente ao menos um elemento em comum: o aparecimento de uma culpa a que segue uma punição. Isso faz com que a sanção, ou seja, o momento em que as culpas cometidas devem ser punidas, como é previsto pelas coerções sociais que regulam as vidas do seres humanos, ocupe sempre um lugar privilegiado, em que há geralmente um castigo como valor de equilíbrio de forças de um enunciador que crê e faz crer na necessidade da punição. 
No âmbito da textualização, observamos que os contos começam todos com uma oração curta e são caracterizados pela maciça presença de orações independentes e coordenadas assindéticas, que são uma projeção da modalidade oral sobre a escrita. A ausência de conectores é, porém, uma presença, porque veicula informação e deixa "espaço", para que o enunciatário complete o que falta. Isso produz um efeito de aproximação do co-enunciador, que é "ativo" e deve realmente participar da enunciação.

A seqüência de orações assindéticas cria um efeito de suspense, que culmina na "trigésima linha", onde acontece o "inesperado" (porém, já anunciado desde a capa do livro): é feita uma revelação para que o enunciatário fique "boquiaberto", surpreso, se impressione com o que é narrado. O final surpreende, subverte a história, as paixões, os julgamentos de valores axiologizados como disfóricos ou eufóricos.

Sobretudo nos momentos de maior tensão do conto, as orações curtas chegam a ser constituídas por apenas uma palavra, e isso se realiza pelas elipses. Como afirma Brunot:

É incontestável que num certo número de frases, nas quais falta um elemento, o verbo por exemplo, nos encontramos em presença de frases incompletas que foram voluntariamente encurtadas. Há, então, elipse, uma elipse que o espírito supre. ${ }^{18}$

É o enunciatário ou co-enunciador, quem deve completar com seu espírito - "esprit" nas palavras de Brunot - o que está faltando. O enunciador deixa "voluntariamente" mais um espaço

\footnotetext{
${ }^{18}$ Il est incontestable que dans un certain nombre de phrases où manque un élément, le verbe par exemple, on se trouve en présence de phrases incomplètes que volontairement on a abrégées. Il y a alors ellipse, une ellipse que l'esprit supplée (BRUNOT, 1936: 18)
} 
vazio e revela um éthos de fôlego curto e acelerado, que diz em trinta linhas, usa orações curtas, escolhe as elipses, condensa o discurso.

Não há um eu instalado nesse discurso (temos uma debreagem enunciva do enunciado), mas, retomando Fiorin:

Mesmo que não haja um eu explicitamente instalado por uma debreagem actancial enunciativa, há uma instância do enunciado que é responsável pelo conjunto de avaliações e, portanto, um eu. [...] Há, pois, um narrador implícito e um narrador explícito. (1996, 65-66)

O narrador é, portanto, implícito. As orações curtas, a escassez de adjetivos e a escrita aparentemente asséptica contribuem para criar um efeito de sentido de objetividade, como se o enunciador estivesse narrando apenas o que está vendo, no momento em que fala.

Essa impressão de objetividade não se confirma, porém, observando mais detidamente a maneira como o narrador se coloca em relação aos atores do enunciado. Acontece, de fato, que nos três contos que analisaremos tem um papel fundamental o discurso indireto livre, que permite ao enunciador um jogo entre o narrador e os atores e entre o que está fora e o que está dentro deles. Diz Maingueneau que

é particularmente cômodo para um autor poder, graças ao discurso indireto livre, deslizar sem nenhum ruptura da narração dos acontecimentos aos propósitos e pensamentos para voltar em seguida à narração dos acontecimentos. Tais "deslizamentos" são preciosos para a descrição da "corrente de consciência" das personagens. (1981: 113) 
E ainda ocorre que há "modificações" do discurso indireto livre tradicional que recriam e ampliam suas possibilidades e misturam suas potencialidades com aquelas da demarcação de vozes dada pela heterogeneidade mostrada e marcada, teorizada por Authier-Revuz (1982, 1990).

O tempo principal da narração é, nos três casos, o presente do indicativo (trata-se de uma debreagem enunciativa do enunciado), tempo verbal do "olhar", que constrói a cena das "verdades" do enunciado e cria um efeito de sentido de simultaneidade entre a narração e os eventos narrados (simulacro de concomitância com o momento da fala). O enunciatário entra, assim, dentro de uma "história" numa debreagem enunciativa temporal do agora e espacial do aqui, que criam a ilusão referencial de coincidir com os seus agora e aqui, reforçando desta maneira ainda mais o efeito de sentido de realidade.

O tempo presente dos textos é um "presente pontual" que ganha, às vezes, um caráter de omnitemporalidade para universalizar as histórias contadas que poderiam ter acontecido em qualquer momento e em qualquer lugar. O presente atualiza a "realidade" dos eventos narrados e reforça a recorrência de um elemento central: nesses contos o que parece nunca é. Anterioridades e posterioridades inserem-se no presente da narração para completar o que é contado: temos, portanto, momentos em que o narrador se volta para trás e o enunciador traz para o texto acontecimentos "passados", assim como há (mais raramente) projeções num futuro que, porém, nunca supera os limites do final do conto.

A imagem de um observador super partes, que não expressa opiniões e se abstém de fazer comentários, cria um simulacro de cumplicidade com o co-enunciador, porque o coloca na mesma posição do narrador-observador (tempo presente, advérbios enunciativos) e lhe dá "voz", 
inclusive deixando espaços vazios na narração, para que ele possa expressar sua opinião quanto aos fatos narrados. Há sempre, porém, avaliações do enunciador "escondidas" no texto que influenciam o enunciatário na formação do seu julgamento.

Contribui para o efeito de aproximação entre enunciador e enunciatário a presença de subentendidos e pressupostos, que caracterizam os contos. Em nenhum deles a situação é claramente exposta: o enunciador/narrador procura fornecer ao enunciatário/narratário os elementos, para que ele possa chegar às conclusões que ele não define completamente.

Para reforçar o efeito de realidade e a idéia da independência dos atores do enunciado, predomina nos contos a voz ativa e, além disso, os sujeitos do enunciado são figurativizados por meio de antropônimos e/ou por meio de seu "papel" na narrativa. Desta forma, se fortalecem e são "responsáveis" por suas ações, até porque "falam" ou porque temos acesso a seus pensamentos com as palavras exatas com as quais foram formulados: a debreagem enunciativa de segundo grau (discurso direto) presente nos três textos é mais um recurso, que confere um efeito de objetividade e de realidade, cria a ilusão de "verdade", a ilusão de estarmos realmente ouvindo a "voz" dos atores do enunciado. 


\subsubsection{LUCANONDIMENTICA}

Aveva una memoria d'elefante, Luca. Adesso è un colabrodo, specialmente per i nomi. Eppure ha appena trent'anni. "Chi ha segnato il gol del Milan?" gli chiedono. E lui rovista affannosamente nella formazione. Senza esito. "Come si chiamava quel tuo compagno delle medie grasso grasso?» Niente. Ma non vuole darsi per vinto. È sicuro che la memoria non l'ha davvero abbandonato. Basta spronarla. Deve inventare un sistema che la induca a funzionare. Un premio o un castigo a cui legare i risultati, buoni o cattivi. E alla svelta, per non perderla. Da due ore si tormenta. Cammina nella sera di Milano. Lento, per non far cadere quel nome che sente salirgli alla soglia della mente. Ma che ogni volta incespica. Come si chiamava, Iddio bono: grasso, capelli ricci e neri, occhi distanti, esse sibilante? E ossessionato. Guarda l'orologio. Le sei meno un quarto. "Se non mi viene in mente prima delle sei, allora morirò entro un anno.»

D'accordo. Il patto con il destino è fatto. Adesso ha uno stimolo. Si sente più freddo. Analitico. Ricomincia la rassegna di lettere dell'alfabeto. A, Aba, Ac, Antinori... No niente vocale iniziale. $B, B a, B e, B i$, Bon... Neppure. Le sei meno dieci. Cap, Car, De, niente nomi composti. Gh, Ghi, $M a, M u$. Le sei meno cinque. $P, P a, P e, P o$. Le sei meno due. $R$, no $S$, nemmeno T, sì, Ta, To, sì, sì, Ton, Tor, Tort... Tortello!!! Si ferma in mezzo alla strada esausto e felice. Guarda l'orologio: le sei spaccate. Un'auto lo travolge.

\section{LUCANÃOESQUECE}

Tinha uma memória de elefante, Luca. Agora é um esquecido, especialmente para nomes. Ainda mais que tem só trinta anos. "Quem marcou o gol do Milan?" perguntam a ele. E ele procura desesperadamente no time. Sem êxito. "Como chamava aquele teu colega bem gordo do ensino fundamental?" Nada. Mas não quer dar-se por vencido. Tem certeza de que a memória não o abandonou de verdade. Basta cutucá-la. Deve inventar um sistema que a induza a funcionar. Um prêmio ou um castigo a que ligar os resultados, bons ou ruins. E rápido, para não perdê-la. Há duas horas atormenta-se. Anda pela noite de Milão. Devagar, para não deixar cair aquele nome que sente subir à soleira da mente. Mas que cada vez tropeça. Como chamava, meu Deus: gordo, cabelos encaracolados e morenos, olhos distantes, o 'esse' sibilante? Está obsessivo. Olha para o relógio. Quinze para as seis horas. "Se não me vem à mente antes das seis, vou morrer em até um ano."

Combinado. O pacto com o destino está feito. Agora tem um estímulo. Sente-se mais frio. Analítico. Recomeça a passar em revista as letras do alfabeto. A, Aba, Ac, Antinori... Não, nada de vogal no início. B, Ba, Be, Bi, Bon... Também não. Dez para as seis. Cap, Car, De, nada de nomes compostos. Gh, Ghi, Ma, Mu. Cinco para as seis. P, Pa, Pe, Po. Dois para as seis. R, não $\mathrm{S}$, também não, T, sim, Ta, To, sim, sim, Ton, Tor, Tort... Tortello!!! Pára no meio da rua exausto e feliz. Olha o relógio: seis horas em ponto. Um carro o arrasta. 
O título "Luca non dimentica" ("Luca não esquece") introduz cataforicamente o elemento essencial em volta do qual se constrói o conto. Colocado numa oração negativa, o verbo "dimenticare” (“esquecer”) afirma e, ao mesmo tempo, refuta a primeira afirmação, incluindo, dessa forma, também o seu contrário. "Esquecer", "não esquecer” e, portanto, “lembrar" estão assim já postos, mas o que acontece com Luca (o ator do enunciado cujo nome é explicitado desde o título) é justamente "não lembrar": Luca que antes sempre lembrava tudo, agora não lembra mais.

O conto começa com dois enunciados de estado, que apresentam respectivamente os predicados elementares de ter - "aveva una memoria d'elefante", tinha uma memória de elefante - e de ser - "è un colabrodo", é um "recipiente cheio de furos", um esquecido. As duas metáforas têm em italiano grande efeito e confirmam o que é antecipado no título: trata-se nesse conto de memória e de esquecimento. À memória infalível que Luca possuía num momento anterior àquele em que o narrador está falando contrapõe-se o "colabrodo" que ele é agora, "especialmente para nomes".

Essa contraposição faz pensar em Mnemosýne, a Memória, e em Léthe, o Esquecimento, que formam no panteão grego um par de forças religiosas. Jean-Pierre Vernant em Mito $e$ pensamento entre os gregos dedica um capítulo aos aspectos míticos da memória e retoma Platão, para o qual "saber não é outra coisa se não lembrar-se" (VERNANT, 1990: 127), além de referir-se à memória como objeto de veneração de que se exalta "ou a fonte de saber em geral, da onisciência, ou o instrumento de uma liberação em relação ao tempo" (VERNANT, 1990: 127). A memória, portanto, como saber e como força que realiza a saída do tempo, mas também como fonte de imortalidade (de vida), em contraposição à morte representada pelo esquecimento. 
Essas reflexões permitem-nos estabelecer uma relação entre os elementos presentes no texto: a memória (lembrar) se associa à vida, enquanto o esquecimento (esquecer) está relacionado à morte. Tudo isso pode ser mais claramente visualizado no seguinte quadrado semiótico, em que se evidenciam as relações de contrariedade, contradição e contraditoriedade, que poderão ser úteis ao longo da análise:

\begin{tabular}{|lr|}
\hline LEMBRAR & ESQUECER \\
Vida & Morte \\
& \\
& \\
NÃO-ESQUECER & NãO-LEMBRAR \\
Não-morte & Não-vida \\
\hline
\end{tabular}

Há mais duas referências trazidas por Vernant que podem ajudar na reflexão sobre o conto em pauta. Uma vem novamente de Platão e a outra encontra-se na Ilíada de Homero. Afirma Platão que as almas sedentas dos defuntos deviam evitar beber no rio da planície do Lethe a água do esquecimento "que nenhum recipiente poderá reter"" e, referindo-se ao mito das Danaides condenadas a esforçar-se em vão "para encher um tonel furado com a água que escorre de uma peneira cheia de buracos" (VERNANT, 1990: 117), acrescenta que esta peneira é "a alma desses infelizes, incapazes, por esquecimento, de não deixar escapar o seu conteúdo" (VERNANT, 1990: 117).

\footnotetext{
${ }^{19}$ Cf. Platão, República, Livro X.
} 
Julgamos, então, que a referência ao colabrodo escolhida pelo enunciador do conto não seja casual. Não encontramos em português uma metáfora que tenha o mesmo valor e decidimos, portanto, usar na tradução o termo "esquecido" no qual se garante a manutenção do primeiro significado, mas um colabrodo é literalmente um recipiente de cozinha crivado de buracos, usado para filtrar canjas e eliminar resíduos de carne, legumes, etc. O lexema possui em italiano um alcance metafórico amplo e imediato e indica também qualquer coisa "cheia de buracos", que não funciona (mais). A analogia com o "tonel furado" e com a "peneira cheia de buracos" mencionada por Platão é, sem dúvida, interessante.

E ainda falando de memória e esquecimento, Vernant cita Homero e a importância, na sua época, dos Catálogos, isto é, das enumerações de nomes. Há um exemplo de Catálogo no Canto II da Ilíada, onde mais de 400 versos são dedicados a inventários de nomes do exército aqueu, com os melhores guerreiros e os melhores cavalos, e depois do exército troiano. Vernant explica que os antigos gregos como Homero e, ainda mais, Hesíodo tinham predileção pelos nomes, porque para os gregos "é através deles que se fixa e se transmite o repertório dos conhecimentos que permite ao grupo social decifrar o seu "passado"' (1990: 111). Eis o valor essencial do nome que ajuda a classificar e a organizar e que estabelece uma ponte entre o presente e o passado.

Pensar nisso fornece uma explicação para o fato de o narrador insistir em dizer, desde o início, que Luca esquecia principalmente nomes. Mais para frente no texto é, de fato, um nome que ele quer lembrar, o nome do colega do ensino fundamental que figurativiza o resgate da memória. E são nomes que os "outros" querem saber perguntando: "Quem era...?” ou "Como chamava...?". 
Voltando ao início do conto, observamos que um hipérbato rompe a ordem direta dos elementos da primeira oração, de forma que o sujeito gramatical "Luca" se encontra no fim da frase e separado por uma vírgula do resto. Essa escolha dá ênfase ao ator do enunciado e cria o efeito de seu nome próprio pertencer também à segunda oração: se não olharmos para a fronteira que constituem a vírgula e o ponto, veremos que o antropônimo está exatamente no meio entre as duas orações, termina a primeira e inicia a segunda sem a necessidade de ser repetido. Além disso, ele enfatiza o sujeito e mostra desde o início que é a partir da sua perspectiva que a história será contada. É preciso dizer que o antropônimo e a idade são tudo o que sabemos do ator Luca, que não tem rosto, nem descrição física, vestimenta ou papel social. Isso basta, contudo, a criar a ilusão referencial e o simulacro de um referente externo ao texto que produz o efeito de sentido de realidade.

Ainda mais se pensarmos que esse sujeito em terceira pessoa marca também seu tempo e seu espaço. O tempo é colocado numa escala humana quantitativa e é medido em horas e minutos e o espaço é o das ruas de Milão, a cidade italiana símbolo, entre outras coisas, da modernidade e da eficiência produtiva, mencionada uma vez pelo nome do seu time de futebol e outra vez porque é lá que Luca está.

À questão da idade precisamos também dedicar atenção, já que contribui de maneira essencial para completar o sentido dessa primeira parte do texto: Luca tornou-se esquecido mesmo tendo "só trinta anos". "Eppure ha solo trent'anni" diz o narrador e o conector "eppure", com valor adversativo, pode ser interpretado como a constatação de uma falta inesperada, de algo que na idade na qual os seres humanos têm seus melhores desempenhos não se poderia prever. A 
juventude contrapõe-se, então, à falta de memória, como se o enunciador dissesse que Luca, sendo ainda tão jovem, não deveria esquecer.

Instala-se uma distância temporal entre os dois enunciados de estado que introduzem o conto: o pretérito imperfeito do primeiro enunciado coloca uma anterioridade durativa em relação ao ponto de vista estabelecido pelo enunciador, que, a partir do segundo enunciado, introduz o momento de referência presente com o presente do indicativo como tempo verbal e com o advérbio enunciativo "adesso" ("agora"), que contribui para o engate do texto à situação de enunciação e para a criação de uma ilusão de concomitância com o "agora" do co-enunciador (já que os advérbios enunciativos e os dêiticos se atualizam todas as vezes que são lidos).

A transformação acontecida é pressuposta: o início do conto mostra ao co-enunciador apenas os momentos que caracterizam o antes e o depois e não diz nada sobre o que aconteceu. Configura-se, mesmo assim, uma narrativa de privação pela mudança do estado juntivo do sujeito que passa da conjunção à disjunção com o objeto valor.

Luca perdeu a memória, ou melhor, a memória o abandonou, como nos faz saber o narrador algumas linhas depois, dizendo - na sua única outra afirmação relacionada ao passado - que Luca: "É certo che la memoria non l'ha davvero abbandonato”. Temos novamente uma negação para afirmar a si mesma e seu contrário, já que dizer que Luca “tem certeza de que a memória não o abandonou de verdade" significa, ao mesmo tempo, enunciar a disjunção (cujo efeito já foi mencionado na primeira linha, quando se diz que Luca agora é um colabrodo) e mostrar qual a reação do sujeito: a certeza de que a disjunção parece ter acontecido, mas não aconteceu. $\mathrm{Na}$ 
perspectiva de Luca, que o narrador transmite, a memória o deixou apenas no modo da mentira, parece assim, mas assim não é ${ }^{20}$.

O sentimento de falta que essa disjunção produz orientará o programa narrativo principal em direção a uma liquidação dessa falta e à recuperação do objeto valor: Luca se configura como um sujeito de busca, dominado pelo querer entrar em conjunção com o objeto valor "memória". A falta determina o seu desejo e guia-o em direção a um novo estado de equilíbrio. Mas vejamos como se configura no conto esse movimento de busca.

O destinador-manipulador aparece no texto na forma de um sujeito coletivo figurativizado pelas vozes dos "outros" que se "ouvem" nas duas debreagens enunciativas de segundo grau. O narrador assinala claramente pelas aspas e pelo verbo de dizer ("gli chiedono", "lhe perguntam") que está citando um discurso alheio e está reproduzindo "literalmente" uma fala que não é sua. Cria-se assim o efeito de sentido de realidade que faz imaginar que aquelas palavras tenham "realmente" sido pronunciadas. Trata-se de duas perguntas colocadas na evidente expectativa de que Luca lembre a resposta: os "outros" querem saber nomes de pessoas que fazem parte do passado (ambas as vezes os tempos verbais são tempos do "passado"). Esse destinador instalado no texto remete a um universo de valores em que são axiologizados euforicamente a memória, o sucesso, o saber e, ao contrário, disforicamente o esquecimento, o fracasso, o não-saber. Assim, a memória se associa à eficiência e, em última instância, à vida e o fato de Luca ter-se tornado um esquecido o faz ir em direção à morte, tanto que não quer acreditar que a memória o tenha

\footnotetext{
${ }^{20}$ Estamos aqui utilizando um dos termos complexos das modalidades veridictórias, que projetam no quadrado semiótico as noções de ser e parecer criando os seguintes resultados: mentira (parecer-não ser); falsidade (não parecer-não ser); segredo (ser-não parecer); verdade (ser-parecer).
} 
realmente abandonado e se declarará disposto a colocar em jogo sua própria vida na tentativa de recuperá-la. O resgate da memória representa, portanto, a aquisição de reconhecimento no âmbito social, mas ambas as vezes as perguntas não são respondidas: a primeira vez a busca pela resposta fica "sem êxito" ("senza esito") e a segunda vez Luca não consegue dizer "nada" (“Niente").

A partir dessas primeiras buscas sem resultado inicia-se o efetivo querer do sujeito que "não quer dar-se por vencido" ("non vuole darsi per vinto") e que, portanto, é o actante-sujeito do percurso de resgate da memória, cuja falta a transforma - como dissemos - em valor e objeto desejado. Luca é, portanto, modalizado pelo querer fazer e pelo não saber e não poder fazer. Falta-lhe a competência para conseguir realizar o seu querer e, portanto, a sua é uma "espera tensa" ${ }^{21}$, pois ele sabe que a conjunção com o objeto valor pode não se realizar ${ }^{22}$.

Há, porém, um percurso passional cuja intensidade varia conforme a história avança: as paixões mudam e passa-se diversas vezes da tensão à distensão para chegar ao relaxamento antes do clímax final. Vários indícios no texto permitem chegar a essa conclusão. Vejamos quais.

Um primeiro sinal de tensão é dado, quando, depois da primeira pergunta, Luca "rovista affannosamente" na memória à procura da resposta. Na tradução para o português utilizamos a expressão "procura desesperadamente", mas cabe observar que a definição de "rovistare" do dicionário Zingarelli revela muito mais. O lexema significa "procurar algo em todo lugar, especialmente fazendo barulho, trocando objetos de lugar, fazendo desordem". A referência é ao

\footnotetext{
${ }^{21}$ Cf. GREIMAS/COURTÉS, s/d : 235.

22 Referimo-nos aqui às sobremodalizações indicadas em BARRos (1990b: 63), pelas quais aflição (tensão) corresponde ao querer ser e ao saber poder não ser.
} 
caos, à confusão, ao barulho num espaço físico. Transferir essa idéia para a memória coloca a dimensão da ansiedade e da tensão, ainda intensificada pelo advérbio affannosamente que, além de indicar a respiração entrecortada pela pressa, remete a algo que provoca angústia e preocupação.

Após a tensão e a dupla "derrota" (Luca não consegue responder a nenhuma das duas perguntas), realiza-se uma primeira transformação no percurso passional. O sujeito percebe o fracasso, "mas não quer dar-se por vencido" ("ma non vuole darsi per vinto"). Como vimos, o narrador diz também que ele "tem certeza de que a memória não o abandonou de verdade" (" $E$ sicuro che la memoria non l'ha davvero abbandonato") e isso provoca no desenvolvimento modal a representação da segurança, que significa distensão: Luca está convencido de que existe uma maneira de fazer sua memória voltar a "funcionar" e que para isso ele precisa inventar um sistema de prêmios e castigos, procurar um meio para alcançar sua meta.

Volta a tensão da espera que se confirma em seguida com a expressão "alla svelta", isto é, "rápido", sem perder tempo; e depois ainda quando o narrador afirma que Luca "da due ore si tormenta" ("há duas horas atormenta-se"), com o explícito aparecimento do tormento, que se apresenta como termo tenso e remete, portanto, ao efeito patêmico da aflição ${ }^{23}$.

Segue mais um momento de distensão: vemos Luca andando lentamente pelas ruas de Milão e acompanhamos uma possível aproximação da realização do objetivo. Ele não quer deixar cair o nome que está quase lembrando "mas que cada vez tropeça" ("ma che ogni volta

\footnotetext{
${ }^{23}$ Cf. BARROS, 1990b: 63-64.
} 
incespica"), não permitindo a realização da ação e criando as condições para mais um sinal de tensão: “è ossessionato” (“está obsessivo").

Vale a pena notar que o percurso tensivo-passional que acabamos de observar é marcado também pelo uso do conector argumentativo mas, que aparece duas vezes num conto que, no plano da textualização, é formado por orações curtas e geralmente assindéticas e em que se renuncia, portanto, aos conectores, criando um ritmo acelerado ${ }^{24}$. Se considerarmos que, segundo afirma Maingueneau, o conector mas antecede a proposição com a "força maior" e segue aquela que deve ser considerada "negligenciável" 25 , podemos tirar algumas conclusões do duplo aparecimento de mas no primeiro parágrafo do conto. Para observar a primeira ocorrência do conector, será interessante iniciar pela pergunta feita por aquele que identificamos como destinador-manipulador coletivo, "Como chamava aquele teu colega bem gordo do ensino fundamental?", depois da qual se diz "nada", ou seja, nenhuma resposta: panorama totalmente negativo, falta de perspectivas. A frase seguinte começa com um "mas" que, permitindo "negligenciar" o "nada" que a antecede, muda o movimento da narração e a faz passar da tensão à momentânea distensão. É a hora em que o narrador diz que Luca não quer dar-se por vencido e cria, portanto, um movimento ascendente em direção a um alto eufórico: Luca quer "levantar-se", quer reagir.

\footnotetext{
${ }^{24}$ Além de mas, aparecem também o conector eppure e $e$. Sobre eppure dissemos que é adversativo e apresenta uma orientação argumentativa marcada. A conjunção $e$ é aparentemente um simples aditivo, mas, estando ela ambas as vezes no início de uma oração e após um ponto, sua função pode ser considerada diferente: podemos pensar que nessa posição $e$ tenha a função de projetar sobre a escrita a modalidade do pensamento. A conjunção pode representar a continuidade e a não-interrupção que são próprias do fluxo do percurso mental, no qual cada idéia está encadeada a outra, sem que haja uma efetiva ruptura.

${ }^{25}$ Cf. Maingueneau, 1997: 167.
} 
A segunda vez em que se utiliza o mas, acontece o contrário: o narrador descreve Luca andando pelas ruas de Milão e se atormentando na tentativa de lembrar o nome que lhe foi perguntado. Percebemos uma parada na tensão e na rapidez que caracterizaram o conto até esse momento e, pela primeira vez, fala-se em lentidão: agora Luca poderia pela lentidão conseguir entrar em conjunção com o nome que ele não soube encontrar na memória. Ele anda devagar porque não quer deixar cair "aquele nome que sente subir à soleira da mente". O verbo "subir" traz a idéia do alto eufórico, da esperança (como efeito de sentido de uma espera relaxada) de que a realização do objetivo esteja próxima, embora o "não querer deixar cair" já prenuncia a possível queda. E é justamente por meio de um mas que de novo se inverte a direção do conto e, desta vez, para o "negativo", deixando o baixo disfórico como última direção argumentativa e, portanto, levando a considerar essa afirmação como a mais forte. Poderíamos representar assim as duas ocorrências do conector: 


\section{$1^{\circ} M A$}

Come si chiamava quel tuo compagno delle medie grasso grasso?

[Como chamava aquele teu colega bem gordo do ensino fundamental?]

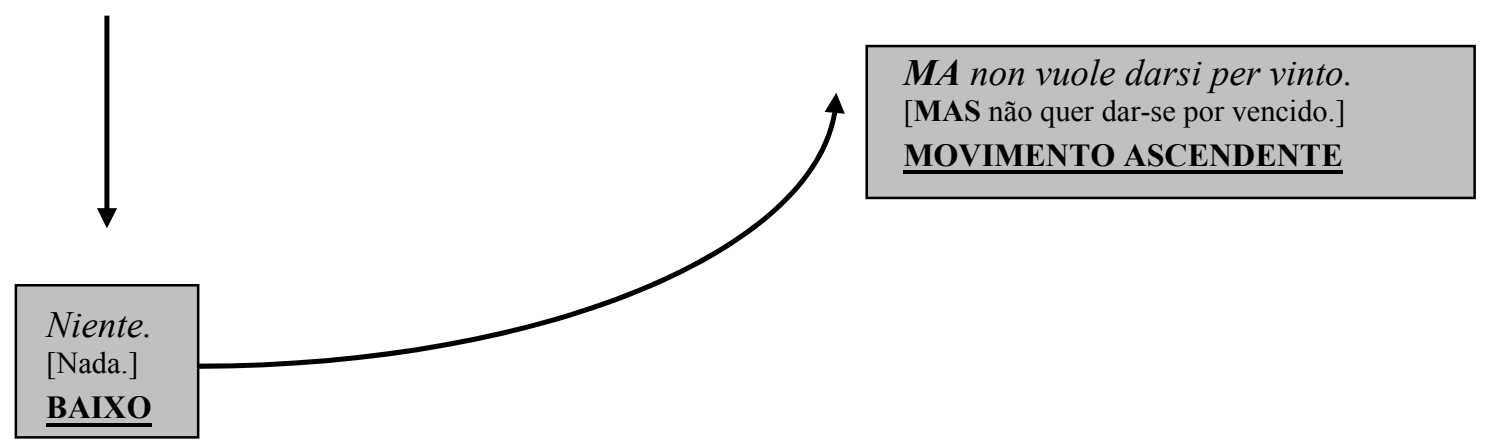

\section{$2^{\circ} M A$}

Cammina [...]. Lento, per non far cadere quel nome che sente salirgli alla soglia della mente. [Anda [...]. Devagar, para não deixar cair aquele nome que sente subir à soleira da mente.]

\section{ALTO}

MA che ogni volta incespica.

[MAS que a cada vez tropeça.] MOVIMENTO DESCENDENTE

A tendência geral pode, portanto, ser definida como de negatividade, por ser o movimento descendente o último que aparece e que, tendo força maior, predomina na construção do discurso. Essa negatividade junta-se, aliás, com vários outros elementos morfossintáticos e com construções discursivas que carregam a negação e atravessam o conto inteiro, a ponto de poder-se considerar que o conjunto forma uma isotopia temática que rege o texto, entendido como um todo de significação. 
Mas pensemos no momento em que lembrar o nome se torna para Luca uma "obsessão" (“È ossessionato"). Em seguida, ele olha para o relógio e faltam quinze minutos para as seis horas. Entra em cena o tempo crônico, definido e marcado pela precisão do relógio, que ganha um papel essencial na segunda parte do conto contribuindo para criar um efeito de sentido de realidade e para figurativizar a inexorabilidade da sucessão dos acontecimentos. Não se diz o que exatamente deixa Luca no estado descrito; fica em aberto para que o enunciatário acrescente o que falta. A obsessão é vista aqui como o tormento incessante, a angústia de quem procura alcançar algo sem conseguir, de quem persegue uma idéia de forma irracional e ainda o faz, sem um motivo aparente e de forma compulsiva. E aí a obsessão transforma-se na obstinação de quem persiste num propósito e numa atitude que não é nem razoável, nem oportuna ${ }^{26}$. É nessa descrição que há pontos de contato entre a obsessão e a obstinação e é aqui que se insere um programa de uso, criado pelo ator do enunciado, um sujeito que pode ser considerado obstinado, se entendemos que:

a obstinação caracteriza o sujeito que não somente quer fazer, mas quer ser aquele que faz, embora saiba que a conjunção a que ele visa pode não se realizar, ou mesmo pode não ser: ele quer apesar dos obstáculos, e a própria resistência alimenta sua vontade. (BERTRAND, 2003: 371)

E quanto mais Luca percebe que a conjunção com o "lembrar" pode não se realizar, mais a quer, tanto que já num momento anterior do texto, o narrador diz - em um dos freqüentes momentos de discurso indireto livre em que sua voz se mistura à voz do ator do enunciado - que Luca deve inventar uma maneira de fazer sua memória funcionar, um prêmio ou um castigo que a

\footnotetext{
${ }^{26}$ Fomos guiados aqui pelas definições de ossessione/ossessionato e ostinazione/ostinato do Dicionário Zingarelli para o italiano, mas consideramos também as definições em português e francês dos Dicionários Houaiss e Petit Robert, que correspondem aos citados lexemas italianos.
} 
induzam a voltar. E é exatamente o que acontece agora: não só ele quer "apesar dos obstáculos", mas "inventa" ele mesmo um novo obstáculo.

Considerando-se um sujeito insuficiente, o ator principal da narrativa cria um pacto com o destino: "Se non mi viene in mente prima delle sei, morirò entro un anno" ("Se não me vem à mente antes das seis horas, vou morrer em até um ano"). Ele se impõe limites a serem respeitados que possam ajudá-lo a alcançar a competência necessária para a realização da performance e se submete ao risco de perder sua própria vida: se ele não lembrar, vai morrer. É assim reforçada a idéia de que há uma oposição /vida/vs /morte/ instalada no texto, já que a morte é a punição pelo esquecimento e a vida o prêmio, caso a memória seja reconquistada.

No programa narrativo instaurado a manipulação é reflexiva e acontece por intimidação: colocando a morte como punição, o sujeito configura uma sanção pragmática que se substitui à simples sanção cognitiva que o teria levado ao reconhecimento social. Há também uma outra significativa transformação e o querer torna-se dever, visto que agora não lembrar significa morte. Luca está disposto a arriscar sua vida e a colocá-la em jogo para recuperar sua memória, assim poderá alcançar a competência necessária para a realização do programa principal, isto é, para entrar em conjunção com o nome, símbolo da memória, que, uma vez resgatado, traz a ele um poder ser (reconhecido pela sociedade) e um poder poder.

Ora, acontece que aquele que parece um pacto que o ator do enunciado faz consigo mesmo, é em seguida apresentado como uma convocação do destino. O co-enunciador descobre isso por meio do discurso indireto livre: o narrador penetra os pensamentos do ator do enunciado e, 
fundindo mais uma vez sua voz com a voz dele, diz: "D'accordo. Il patto con il destino è fatto." (“Combinado. O pacto com o destino está feito.”)

Se o pacto é com o destino, podemos dizer que o sujeito introduz também um novo destinador-julgador, que acaba por substituir o destinador coletivo identificado antes. Com esse destinador Luca fixa os termos da sanção, impondo rígidos limites de tempo (lembrar antes das seis horas / morrer em até um ano) e colocando a morte como castigo. Para a configuração tanto da condição colocada, quanto da conseqüência é essencial a questão da temporalização: as expressões usadas indicam um "tempo humano" medido com a precisão do relógio e do calendário. Esse tempo entra em cena imediatamente antes do pacto, quando Luca olha para o relógio e são quinze para as seis horas.

Como vimos, ao longo de todo o conto, a voz que constrói a história é a de um narrador que descreve Luca por "dentro", mostrando ao narratário o percurso de resgate da memória. No simulacro construído pelo enunciador, o que se passa no seu "cérebro" está exposto para que o enunciatário possa acompanhar os passos e os "movimentos" do ator. Tem um papel significativo na geração desse efeito que o principal tempo da narração seja o presente do indicativo que cria a ilusão de termos um acesso privilegiado aos pensamentos e às paixões do sujeito do enunciado $n a$ hora em que estão acontecendo, de "vê-los" se desenrolarem diante de nós.

Cabe destacar que, contrariamente ao que acontece no restante do texto, no momento em que são mostrados os termos exatos do pacto se realiza pela primeira e única vez um nítido distanciamento entre narrador e ator. Pela primeira vez, Luca diz eu, pois há uma clara debreagem enunciativa de segundo grau e a separação entre as duas vozes é mostrada e marcada 
pela presença das aspas, com as quais o enunciador cria a ilusão de que as palavras que lemos são exatamente aquelas que Luca "pensou".

Possui aqui grande importância a idéia do pacto fiduciário entre enunciador e enunciatário, pelo qual este aceita que aquele crie um narrador com a "capacidade" não só de conhecer os pensamentos do ator do enunciado, mas também as palavras exatas com que ele se deu.

Vale a pena olhar essas "palavras" um pouco mais de perto. Em primeiro lugar, a debreagem, por meio da qual Luca cria o pacto com o destino, é um ato de linguagem que provoca uma mudança imediata do estado das coisas, pois é pela própria linguagem, pela própria enunciação que o acordo se realiza. Trata-se de uma transformação que não requer o consentimento social para ser considerada válida ou não válida. Na verdade, o sujeito enuncia o pacto para ele mesmo e realiza pela força ilocutória uma primeira transformação que é acionada pelo interlocutor, apesar de não estar a cargo exclusivamente dele. Luca não diz "vou me matar", mas sim "vou morrer", sendo necessária para isso a intervenção de um agente externo, identificado logo após o fechamento das aspas com o destino, mas ausente como interlocutário na debreagem, através da qual tomamos conhecimento do pensamento do ator do enunciado e conhecemos os termos do pacto que ele cria $^{27}$. O discurso de Luca inclui - tanto na condição, quanto na conseqüência - apenas a primeira pessoa do singular, colocando em cena, portanto, o sujeito com ele mesmo e não com o outro. O "pensamento" de Luca é um dizer, mas também um fazer (estabelece os termos de um pacto) e um fazer fazer (persuasão que deve levar ele mesmo a lembrar o nome, símbolo da memória reconquistada) reflexivo.

\footnotetext{
${ }^{27}$ Para uma classificação dos atos ilocutórios, cf. MAINGUENEAU, 1996a:12.
} 
O pacto é expresso por meio de uma oração condicional, um período hipotético de tipo I ou della realtà (“da realidade”) para trazer a terminologia comumente usada para descrever a língua italiana $^{28}$. Esse período hipotético é factual e prevê que sejam usados os tempos do indicativo na formação de prótase (p) e apódose (q). As duas orações não são apresentadas como certamente e independentemente "verdadeiras", "mas dada a verdade de p deve seguir a verdade de q",29, isto é, caso a primeira se verifique, a segunda deve verificar-se também. No nosso caso, isso significa que, se Luca não lembrar o nome de seu colega antes das seis horas (se a primeira for verdadeira), ele vai morrer em até um ano (a segunda deve ser verdadeira).

Além disso, o período hipotético escolhido para expressar o pacto contém um presente do indicativo na prótase (condição), introduzida pelo conector condicional se, e um futuro do presente na apódose (conseqüência). Enquanto dêitico, porque indica uma ação posterior em relação ao momento da enunciação, o futuro contido no pacto de Luca, pode ser interpretado como indicando um acontecimento que possui valor puramente eventual (já que não se pode ter conhecimento certo dos eventos que pertencem ao domínio do futuro), segundo Bertinetto, “contudo, no falante existe muitas vezes uma certeza subjetiva da realização do evento indicado por meio do futuro." ${ }^{30} \mathrm{O}$ uso desse tempo no lugar, por exemplo, de um igualmente possível presente do indicativo na mesma posição, pode indicar uma maior certeza e conferir maior força ao enunciado.

\footnotetext{
${ }^{28}$ Cf. SERIANNI, 1997: 411.

29 "[...] ma data la verità di p deve seguirne la verità di q." (MAZZOLENI, 1991: 752).

30 "Tuttavia, nel parlante esiste spesso una certezza soggettiva, circa il verificarsi dell'evento indicato mediante il futuro semplice.” (BERTINETTO, 1991: 115)
} 
“O pacto está feito.” Depois disso, há mais uma mudança no estado tensivo. O estímulo que o pacto constitui faz com que a tensão da obsessão seja substituída pela distensão da frieza e da capacidade de análise ("Si sente più freddo. Analitico."), que contrasta, contudo, com o passar em revista as letras do alfabeto e, principalmente, com a manifestação do transcorrer do tempo, dada pela referência ao horário em intervalos cada vez menores e um ritmo cada vez mais rápido (faltam dez, cinco, dois minutos para as seis horas), que cria o efeito da aceleração. Os minutos que passam, enquanto Luca não consegue chegar ao fim de sua performance, aumentam a tensão. Se Luca não conseguir superar a barreira que ele mesmo criou, terá de morrer no prazo que ele estabeleceu. Une-se a isso uma série de negações (no, niente, neppure, nemmeno) que representam os sucessivos fracassos em busca do nome esquecido e que também contribuem para criar tensão.

Aparecem ainda as reticências, que representam semi-simbolicamente as interrupções no "percurso do cérebro" que procura lembrar, percorrendo caminhos que podem levar a reconquistar o objeto almejado. Faltam dois minutos para as seis horas. Há mais duas negações, até que finalmente ele começa a perceber que se está aproximando o momento em que pode conseguir recuperar a memória, o saber e o sucesso, enquanto se esgota também o prazo que ele mesmo se deu, mas que colocou nas mãos do "destino".

Finalmente lembra: "Tortello!!!"31. Os três pontos de exclamação são mais uma representação semi-simbólica do percurso que vai do esquecimento à memória, da angústia ao

\footnotetext{
${ }^{31} \mathrm{O}$ nome possui dois sentidos em italiano, ambos relativos a comida: pode indicar um enrolado de massa com recheio de ricota e espinafre ou outras verduras; ou pode também designar um doce típico de Milão feito com farinha de trigo, ovos e manteiga e frito em gordura de porco. A segunda definição, além de criar uma ligação com o resto do
} 
alívio. Luca "pára no meio da rua exausto e feliz" e há finalmente o relaxamento, a felicidade. Agora Luca sabe ser possível a conjunção com o objeto desejado e isso parece ser a conclusão do percurso narrativo. Olha para o relógio e são seis horas em ponto. Parece realizada a performance, mas não é assim. Mais uma vez o que parece, não é: Luca devia lembrar o nome antes das seis horas e quando ele lembra, o relógio já marca as seis horas em ponto. Tarde demais. O pacto (com o destino) não foi respeitado e chega o castigo: "Um carro o arrasta" ("Un'auto lo travolge”).

Sem conectores explicitados, essa última oração não elimina nenhuma das possíveis hipóteses de leitura: constata o que aconteceu. Sabemos apenas que chegamos ao momento da sanção e que a sanção é negativa: o atropelamento é inserido no conto como punição.

Trata-se, aliás, de uma das raríssimas ocorrências em que Luca aparece no texto como ser "agido", já que ele é actante sujeito desde a primeira linha que continua sendo sujeito da maioria dos predicados que aparecem no conto. Não é assim quando os "outros" perguntam ("gli chiedono", "lhe perguntam"), em que se explicita a primeira manipulação; não é assim quando se diz que "a memória não o abandonou de verdade" ("la memoria non l’ha davvero abbandonato"), em que há uma referência à competência; e não é assim agora que estamos na fase da sanção.

E essa sanção vem de "fora" figurativizada pelo automóvel que "arrasta" Luca. Pela maneira como é apresentada e como o enunciador procura jogar com os elementos narrativos, o

texto, por se tratar de um doce da cidade nele explicitamente mencionada, remete ao fato de o colega, cujo nome deve ser lembrado, ter sido caracterizado como gordo. 
co-enunciador é levado a crer que é o destino como uma espécie de grande destinador-julgador transcendente que intervém.

Voltar ao título pode ajudar a encontrar outros indícios: por que o conto foi intitulado “Luca não esquece”? O que ele não esquece? Luca não esquece o nome (no final lembra), não esquece o pacto, segundo o qual ele devia lembrar antes das seis horas, e não esquece de olhar o relógio e de verificar se conseguiu respeitar os limites de tempo que estabeleceu. É ele que liga o seu sucesso a prazos precisos, não conseguindo livrar-se nem do tempo e nem de si mesmo. Mas há uma coisa da qual Luca se esquece: da prudência, que o impediria de parar no meio da rua e de ser levado pelo carro. 


\subsubsection{OCCHI DI PAOLA}

Non può dormire. Qualcosa lo tormenta. Ma non riesce a capire cosa. Fatto sta che da due ore si rigira nel letto, lui che, come dice Paola, dorme a comando. La guarda, addormentata sul fianco. Dalla massa dei capelli scuri, ora tinti, emerge nella semioscurità il profilo della guancia, ancora piena e morbida. I suoi grandi occhi sono nascosti dalle palpebre, ma Duccio li immagina, azzurri, appena ingrigiti dagli anni. E d'improvviso capisce. É per quel pomeriggio. Esattamente vent'anni prima. Il pomeriggio in cui tradi Paola. Con la moglie di un suo caro amico, per giunta. Poi tornò a casa, si fece la doccia, mangiò con lei, scherzò, guardarono la tv. Quando andarono a letto, lui si addormentò subito. Dunque è così che vanno le cose, pensò, al risveglio: nessun rimorso, nulla cambia. Si può tradire e farla franca, anche con se stessi. Si può tranquillamente convivere con i propri peccati.

Non l'ha più fatto. Aveva perfino dimenticato che fosse accaduto. Ora ricorda. Guarda Paola e vorrebbe urlare. Lei si sveglia, lo vede seduto sul letto. "Cosa ti succede, come mai sei sveglio?» domanda. "Ho avuto un incubo» risponde lui. "Ho sognato che ti tradivo con Franca, sai, la moglie di Giorgio.» Lei si gira dalla sua parte. Gli accarezza la mano. "Grazie per averlo chiamato incubo» dice. Lui sorride, si sdraia nuovamente. Lei continua ad accarezzargli la mano e subito lui si addormenta. Si spengono i lampioni della piazzetta. Ora la stanza è buia. Nell'oscurità gli occhi di Paola sono aperti. Un po' meno azzurri, un po ' più grigi.

\section{OLHOS DE PAOLA}

Não pode dormir. Alguma coisa o atormenta. Mas não consegue entender o quê. O fato é que há duas horas se revira na cama, ele que, como diz Paola, dorme quando quer. Ele a olha, adormecida de lado. Da massa dos cabelos escuros, agora tingidos, emerge na semi-escuridão o perfil da bochecha, ainda cheia e macia. Seus grandes olhos estão escondidos pelas pálpebras, mas Duccio os imagina, azuis, levemente acinzentados pelos anos. E de repente entende. É por causa daquela tarde. Exatamente vinte anos antes. A tarde em que traiu Paola. Com a esposa de um querido amigo dele, ainda por cima. Depois voltou para casa, tomou banho, comeu junto a ela, brincou, assistiram tv. Quando foram para cama, ele dormiu logo. É assim, então, que são as coisas, pensou, ao acordar: nenhum remorso, nada muda. Pode-se trair e não ser punido, nem por si mesmo. Pode-se tranqüilamente conviver com os próprios pecados.

Nunca mais o fez. Esquecera até que tivesse acontecido. Agora lembra. Olha para Paola e gostaria de gritar. Ela acorda, o vê sentado na cama. "O que acontece com você, por que está acordado?" pergunta. "Tive um pesadelo" responde ele. "Sonhei que te traía com Franca, sabe, a mulher de Giorgio." Ela vira do seu lado. Faz um carinho na mão dele. "Obrigada por chamá-lo de pesadelo" diz. Ele sorri, deita de novo. Ela continua lhe fazendo carinhos na mão e logo ele adormece. Apagam-se os lampiões da pracinha. Agora o quarto está escuro. Na escuridão os olhos de Paola estão abertos. Um pouco menos azuis, um pouco mais cinza. 
O conto "Occhi di Paola" ("Olhos de Paola") apresenta no plano do narrado uma traição ou, mais especificamente, um adultério: um marido trai, violando a "obrigação" da fidelidade matrimonial. Há uma interdição (dever não fazer), imposta ao sujeito pelas normas sociais, morais e culturais ligadas ao vínculo do casamento e o texto é construído a partir dos conflitos gerados pela transgressão realizada.

O narrador começa com um tempo presente, criando uma ilusão de concomitância entre a situação narrada, a narração e o presente do co-enunciador. Ele usa uma terceira pessoa, mas sem explicitar um sujeito gramatical. Descobre-se que o ator do enunciado é de gênero masculino pelo pronome pessoal catafórico ("lo" em italiano, "o" em português), que antecede o nome próprio, citado só algumas linhas depois. A catáfora contribui para criar o efeito de suspense e motiva a prosseguir a leitura, modalizando o enunciatário pelo querer saber. Além disso, serve para introduzir o sujeito de cuja perspectiva é contada a história. Ele não recebe nenhuma qualificação descritiva: suas propriedades são determinadas pelas ações e pelas paixões.

Desde a primeira oração, o sujeito é apresentado ao co-enunciador como estando inquieto e agitado. "Non può dormire" diz o narrador no início do conto e configura assim uma tensão. A leitura do conto inteiro permite-nos formular a hipótese de que a imagem do não poder dormir dessa primeira oração seja a figurativização do "remorso" que se contrapõe ao adormecer logo que representa a consciência tranqüila e que aparecerá duas vezes ao longo do texto - uma vez no meio e uma no final -, estabelecendo relações que lhe fazem adquirir sentido. Além disso, sendo o sono (dormir) o momento de suspensão da vigília e das experiências conscientes, contrapõe-se 
à condição de quem está desperto (não conseguir dormir/acordar), que é a hora da consciência e, portanto, do julgamento das ações.

É interessante destacar que na contraposição entre o não conseguir dormir da consciência pesada e o adormecer logo da consciência tranqüila ecoa, também, a metáfora de proveniência religiosa do "sono dos justos", que remete à idéia do prêmio para o Bem e do castigo para o Mal. Há uma referência à religião e, portanto, à cultura, que evidencia a oposição semântica do nível fundamental /natureza/ vs /cultura/, que perpassa o conto e constitui o mínimo de sentido a partir do qual será possível construir o restante.

Na segunda oração do conto, o narrador diz: "Qualcosa lo tormenta” (“Alguma coisa o atormenta"), que confirma a tensão identificada na primeira frase e introduz o tormento lexicalizado no predicado. O tormento é aqui aflição, porque o sujeito não age, mas "é agido" por algo que não entende o que é. É acionado assim um percurso patêmico, cuja tensão aumenta por estar o sujeito em disjunção com o saber e por ser incerta a conjunção.

O enunciador constrói nesse início do texto uma "visível" perturbação e põe em cena um sujeito que sente seu corpo e manifesta uma paixão. Ainda mais que seu comportamento de agora contraria a "normalidade" explicitada logo em seguida: ele costuma ser alguém que "dorme a comando”, isto é, imediatamente após deitar, placidamente e sem dificuldade. Quem diz isso é Paola, cujo nome próprio parece introduzido quase "por acaso" e sem uma ênfase especial: "como diz Paola" afirma o narrador, que, na descrição da cena em que o ator do enunciado não consegue dormir, mostra e marca a heterogeneidade, separando seu discurso do discurso dela, 
que se constitui como a voz da familiaridade. Ela conhece Duccio e seus hábitos, sabe como ele é e o que ele faz na hora de dormir.

O aparecimento do antropônimo "Paola", apesar de não ter grande destaque, chama a atenção do enunciatário, porque já foi mencionado no título, que, aliás, antecipa que os "olhos de Paola" são um elemento essencial na narrativa. O nome próprio é mencionado ainda três vezes ao longo do conto: duas vezes como "objeto" de ações de Duccio ("Il pomeriggio in cui tradi Paola", “A tarde em que traiu Paola"; “Guarda Paola e...”, “Olha para Paola e...”) e uma vez, a última, em que constitui um conjunto com os olhos, exatamente como no título.

De Paola não sabemos muito, mas dela é dada uma descrição física do ponto de vista de Duccio, por sua vez filtrado pelo narrador, que sabe o que ele pensa e imagina. Paola está dormindo e seu marido observa na "semi-escuridão" do quarto a massa de cabelos morenos, a bochecha cheia e macia e os grandes olhos azuis imaginados atrás das pálpebras.

A descrição transmite uma avaliação euforizada de seu corpo caracterizada pela “abundância": seus cabelos são muitos (uma "massa”), sua bochecha é cheia e seus olhos são grandes. Há, porém, para cada um dos elementos uma referência ao tempo e à idade que atenua a euforização: os cabelos são "tingidos", a bochecha é "ainda" cheia e os olhos são "levemente acinzentados pelos anos". Paola é descrita, então, como não mais tão jovem e essa referência pode remeter ao campo semântico da experiência e da perda da inocente confiança própria da juventude. 
É introduzida nesse momento do conto uma figurativização cromática ligada aos olhos de Paola que é importante sublinhar, porque será utilizada, preenchida de outros elementos, também no final do texto. Aqui o enunciador usa as cores para referir-se ao transcorrer do tempo e o cinza tem a função de indicar, em contraposição ao azul, os anos que passam.

Após a descrição, duas frases: "E de repente entende. É por causa daquela tarde." ("E d'improvviso capisce. È per quel pomeriggio”) A primeira relação que se estabelece é entre o predicado entende e a oração "Mas não consegue entender [...]" do início, que se referia ao "tormento" que não deixava Duccio dormir, mas, na verdade, a posição em que o verbo é colocado faz com que ele possa ser referido também à cor dos olhos de Paola, indicando que talvez não foi apenas por causa do passar do tempo que "perderam o azul".

A ruptura causada por essas duas frases interrompe a seqüência cronológica da narrativa e introduz uma analepse, em que o efeito de sentido de realidade e de ancoragem temporal é dado pelo uso da expressão de tempo "Esattamente vent'anni prima". É evidente a intenção de criar o simulacro de um tempo "real" e de fazer crer numa "real" lembrança, já que o número preciso de anos é ainda acompanhado pelo advérbio "exatamente", como se o ator do enunciado voltasse no seu passado, da maneira como só quem viveu pode fazer, para recuperar na memória um acontecimento preciso. O conto, que começa in medias res, pode assim mostrar, através da reconstrução de um acontecimento anterior ao momento da enunciação, a razão pela qual Duccio não consegue dormir. É narrada a traição, o episódio central por meio do qual o co-enunciador entra em conjunção com o saber que lhe faltava no início, da mesma forma que faltava também ao sujeito do enunciado que no começo não conseguia "entender". 
O dêitico enuncivo "quel" ("aquele") e o advérbio de tempo também enuncivo "prima" ("antes"), contraposto ao advérbio enunciativo "da due ore" ("há duas horas") colocado pouco antes, também marcam a separação e antecipam a mudança para um tempo "distante" do momento da narração. Muda a perspectiva e é introduzido, para a descrição da traição, o "tempo da memória”. A performance narrada é anterior à tensão provocada pelo remorso de agora, a que o co-enunciador assiste, e o tempo verbal escolhido para a narração é o passato remoto. Analogamente ao passé simple do francês, o passato remoto (chamado também passato semplice) é o tempo da história, como foi definido por Benveniste ${ }^{32}$, ou seja, um tempo enuncivo, que "indica uma concomitância em relação a um momento de referência pretérito" (FIORIN, 1996:152), dada no nosso caso pelo marco temporal pretérito "exatamente vinte anos antes". A ação distancia-se assim do momento da enunciação, criando um efeito de sentido de afastamento do presente. Cabe ressaltar que esse afastamento não é provocado pela efetiva distância temporal, como a denominação do tempo (passato “remoto") poderia induzir a pensar: o que importa aqui é a eliminação - na perspectiva do enunciador - de qualquer relação com o momento da enunciação e o recuo do narrador que não mostra envolvimento com os fatos narrados.

Aspectualmente o passato remoto é um tempo perfectivo. Isso significa que é usado para falar de acontecimentos acabados, pontuais, limitados e dinâmicos: são assim os predicados usados para textualizar a traição ("Il pomeriggio in cui tradi Paola") e em seguida a série de ações do cotidiano (tornò a casa, si fece la doccia, mangiò con lei, scherzò, guardarono la tv, andarono a letto, si addormentò subito) que figurativizam a normalidade e, para além da

\footnotetext{
${ }^{32}$ Diz Benveniste: "Os tempos de um verbo francês não se empregam como os membros de um sistema único; distribuem-se em dois sistemas distintos e complementares. Cada um deles compreende apenas uma parte dos tempos do verbo; todos dois estão em uso concorrente e permanecem disponíveis para cada locutor. Esses dois sistemas manifestam dois planos de enunciação diferentes, que distinguiremos como o da história e o do discurso." (2005: 261-262).
} 
excepcionalidade representada pela traição que foi descrita, devem criar um parecer que oculte o ser: Duccio procura não parecer um "marido infiel", comportando-se como o marido de sempre.

O passato remoto é usado, também, para colocar num passado acabado e afastado do momento da narração o pensamento do ator do enunciado, que segue à cena descrita: "Então é assim que são as coisas, pensou, ao acordar (pensò, al risveglio): nenhum remorso, nada muda. Pode-se trair e não ser punido, nem por si mesmo. Pode-se tranqüilamente conviver com os próprios pecados." Esse momento de "intimidade" com o ator do enunciado, em que o coenunciador tem acesso a sua consciência de vinte anos antes, é essencial. Primeiro, porque põe em cena explicitamente tanto o "remorso", quanto os "pecados", assim julgados pelas coerções sociais estabelecidas pela semântica global do conto, que remetem a uma sociedade e a uma cultura. Em segundo lugar, porque expõe a possibilidade de não receber punições pelos pecados e de conviver "tranqüilamente" com eles. O pensamento de Duccio é a representação da razão fria e distante que analisa as paixões e as define depois de vivê-las e a tranqüilidade que o sujeito verbaliza mostra um relaxamento em nítido contraste com a aflição que foi apresentada no início do conto e com a qual ele agora precisa operar. No então relatado, essa paixão aparece como o momento final de um percurso implícito, no qual se pressupõe um sujeito à espera da sanção negativa por ter cometido o "pecado" da traição. Ele sabe poder ser sancionado, mas o julgamento não chega, nem do espaço social ligado à comunidade, nem dele mesmo como personalização de um sujeito coletivo produto da cultura ("Si può tradire e farla franca, anche con se stessi”). É nesse momento que ele manifesta um estado tensivo de alívio, porque crê não ser mais possível a sanção. 
Do ponto de vista da sintaxe discursiva, esse pensamento seria considerado discurso direto, se estivesse "fechado" por aspas, que delimitariam o espaço do eu e o distanciariam do espaço do outro, mostrando e marcando a heterogeneidade. A escolha de eliminar as aspas faz com que a voz do narrador e a voz do ator se misturem. Não colocando uma barreira gráfica para separá-las e indicar o início e o fim da "fala" do ator do enunciado, o narrador deixa que a voz do ator invada seu espaço e, desta forma, apropria-se dela e cria ambigüidade no discurso por meio da oposição entre debreagens de primeiro e de segundo grau, que fazem confluir duas vozes.

Poderíamos, então, pensar que o que lemos é um discurso indireto livre, não fosse o verbo de dizer no passato remoto ("pensò al risveglio"), que o narrador introduz, mostrando assim que, na verdade, está reportando o pensamento do ator do enunciado. Essa escolha do enunciador pode ser interpretada como uma forma de avaliar o sujeito do enunciado: se o enunciador não separa claramente narrador e ator do enunciado é porque quer que o co-enunciador receba as palavras e a reflexão enunciada como sendo de ambos e fazendo parecer que a voz que produz o texto endossa a opinião de Duccio.

É ainda interessante observar que o pensamento é expresso na forma impessoal: indetermina-se assim o sujeito, criando o efeito de generalização. Além disso, o tempo verbal usado é o presente do indicativo com valor de presente gnômico que exprime algo que vale para sempre, descrevendo estados considerados imutáveis (“É assim que são as coisas”). Constrói-se o efeito de "verdade absoluta", negado, porém, no enunciado: Duccio acreditava que os "pecados" pudessem não ser punidos e que se pudesse conviver com eles sem sentir "remorso", mas no agora mostrado no enunciado sente, de repente, que não é assim e a angústia do presente desmente essa afirmação. Parece e é verdade no conto, que o sujeito não sentiu "remorso" no 
momento em que cometeu o seu "pecado", já que na mesma noite da traição, quando o casal foi deitar, "ele dormiu logo" ("lui si addormentò subito"). Isso figurativiza - como já vimos - a tranqüilidade de então, que se contrapõe ao remorso de agora por causa do qual "não pode dormir" ("non può dormire"): o sujeito relaxado que emerge desse pensamento deu lugar a um sujeito tenso e atormentado.

A frase seguinte inicia um novo parágrafo que se abre com uma cisão: uma nova mudança do tempo verbal. Trata-se desta vez de um passato prossimo (dito também passato composto), que, analogamente ao passé composé do francês, é o tempo do discurso que "indica anterioridade em relação ao presente" (FIORIN, 1996a: 152) e é por isso um tempo enunciativo. Com ele o passado "irrompe" no presente: "Non l'ha più fatto" ("Nunca mais o fez"), diz o narrador ao narratário, acrescentando que "Aveva perfino dimenticato che fosse successo" ("Esquecera até que tivesse acontecido"), onde o trapassato prossimo (paralelo ao plus-que-parfait do francês) indica uma ação anterior a outra, também expressa num tempo do passado. Trata-se, portanto, de um tempo sempre enuncivo que não pode nunca estar diretamente relacionado ao momento da enunciação. Como afirma Bertinetto, “o acontecimento é assim relegado a um passado que, mesmo não sendo distante do momento da enunciação, é apresentado como desprendido dele". 33

Aqui a anterioridade de referência não está expressa, até porque o trapassato prossimo é o predicado da oração principal, mas pode ser reconstruída a partir do contexto: antes do agora em que o remorso volta, o distanciamento do "pecado" havia até produzido o esquecimento.

\footnotetext{
33 "L'evento viene così relegato a un passato che, anche se non è lontano dal momento dell'enunciazione, viene tuttavia presentato come sganciato da esso." (BERTINETTO, 1991: 105).
} 
Constatar que o sujeito nem saiba mais ter cometido o "pecado" contribui, então, para construir um percurso temático que o avalia com indulgência, mostrando ao co-enunciador que, mesmo tendo traído, ele não merece um julgamento negativo. De fato, enquanto o passato remoto, com o qual é contada a traição, produz o efeito de afastamento do momento da enunciação e, portanto, diminui a relevância do narrado, o passato prossimo escolhido para iniciar o segundo parágrafo e reintroduzir o agora aproxima o que é narrado do momento da narração. Vale para o passato prossimo, o que Benveniste afirma descrevendo o passé composé que:

É o tempo daquele que relata os fatos como testemunha, como participante; é, pois, também o tempo que escolherá todo aquele que quiser fazer repercutir até nós o acontecimento referido e ligá-lo ao nosso presente. (2005: 270)

Isso significa que o enunciador quer que chegue e permaneça com mais força no coenunciador a idéia que Duccio nunca mais traiu e revela uma tendência ao "perdão", argumentando em direção a uma visão benevolente do pecado cometido "uma só vez" e depois esquecido.

Volta o presente da narração: "Agora lembra" ("Ora ricorda"), diz o narrador, e essa frase faz voltar à tensão do primeiro parágrafo. O sujeito é agora modalizado pelo saber ("Agora lembra") e pelo dever fazer saber ("[...] e gostaria de gritar") atenuado e sobremodalizado pela presença de um futuro do pretérito que expressa o desejo não realizado (gostaria de gritar, mas não grita). 
A narrativa sofre um desdobramento polêmico e Duccio sincretiza papéis de um sujeito de fazeres contrários: por um lado, é o marido infiel do passado e, por outro, o marido arrependido do presente.

No passado, ele não sente remorso e chega a afirmar como verdade absoluta ser possível conviver "tranqüilamente" com os pecados. Há nesta fase um sujeito pragmático que $f a z$, porque trai e depois age com naturalidade, e um sujeito cognitivo, que sabe e chega a conclusões após o acontecido.

No agora (simulacro do momento da enunciação), o sujeito é pego de "surpresa" e manipulado pela consciência: lembra o pecado que até havia esquecido e é tomado pelo remorso; ele precisa contar, colocar em palavras, para libertar-se do pecado. Aqui também ele é um sujeito pragmático do fazer e cognitivo do [não] saber: "aveva perfino dimenticato che fosse accaduto" equivale a dizer que não sabia e se contrapõe a "adesso ricorda", ou seja, sabe. A contraposição entre saber e não saber, que afasta o pecado e reduz a culpa, é do mesmo tipo daquela que se delineia na primeira parte do texto quando Duccio, que no início "non riesce a capire" ("não consegue entender"), “d'improvviso capisce” (“de repente entende”).

Mencionamos várias vezes até agora dois elementos essenciais desse conto: o "pecado" e o “remorso". É preciso entender melhor o que representam.

Em primeiro lugar, dizer "pecado" remete imediatamente à já citada oposição categorial básica /natureza/ vs /cultura/ e refere-se à visão cristã ou, mais em geral, religiosa do mundo, em que há culpados e inocentes e, por conseguinte, as paixões contrapostas "remorso" vs 
“consciência tranqüila”. O pecado pressupõe uma violação das leis religiosas e das vontades divinas, que - como diz o dicionário Zingarelli - é "livre ou voluntária" e, portanto, um ato consciente. É exatamente a partir do saber relacionado à culpa cometida que nasce o "remorso", que o dicionário define assim: "tormento, aflição provocada pela consciência de ter feito o mal". Trata-se, portanto, de uma paixão de falta, que no conto surge pelo aflorar de uma lembrança dolorosa (justamente a lembrança da culpa cometida) e pede uma liquidação, uma ação que a resolva: há, por um lado, uma projeção no passado do pecado e, por outro, um movimento em direção ao futuro, em que a falta pode ser resolvida.

É a memória, então, que traz de volta a traição e a lembrança de que não ocorreu uma sanção para encerrá-la: o "pecado" não foi punido nem perdoado. Realiza-se dessa forma um reviver e vem à tona a necessidade de que a performance acontecida no passado seja sancionada. O sujeito é um sujeito em falta por não ter sido submetido a uma sanção e busca uma liquidação dessa falta, que só uma nova sanção pode dar-lhe.

Com a manipulação do remorso instaura-se um programa narrativo. Duccio deve contar. A sua competência é, porém, incompleta, porque sabe contar a traição, mas não pode, porque não tem coragem, tem medo de contar e não crê mais na possibilidade de não ser punido se o pecado for revelado. Por isso, a performance não se realiza "completamente". Duccio confessa a traição, mas como se tivesse sido um sonho, aliás, um pesadelo, como diz à mulher. Ele, que no passado manteve a tranqüilidade por ter deixado a traição no segredo do ser e não parecer, usa agora de novo o jogo entre o parecer e o ser para alcançar o alívio. 
O remorso é aqui aspectualizado pela duratividade, já que há um momento incoativo, em que o sujeito se mostra inquieto sem saber por quê, descobre que é por causa da traição e começa a sentir a culpa; logo em seguida, observamos uma fase cursiva durante a qual o sujeito opera com o remorso; e, por fim, um desfecho, aspectualmente terminativo, no qual pela linguagem, pela verbalização ele se libera da culpa e recupera a tranqüilidade.

A cena em que acontece essa "libertação da culpa" une-se à primeira: de novo vê-se o casal na cama dormindo ou tentando dormir. De novo Duccio está acordado. Desta vez Paola acorda também, vê o marido sentado no meio da cama e pergunta o que está acontecendo.

Observa-se aqui uma verticalidade no conto. A única outra ocorrência dessa dimensão verifica-se quando Duccio volta para casa depois da traição. Ambas as vezes percebemos o ator do enunciado que está pensando na traição acontecida e se relaciona com Paola sem revelar-lhe a "verdade" sobre o seu pecado. E ambas as vezes temos, portanto, um momento de consciência contraposto ao resto da narrativa que se desenvolve no eixo da horizontalidade da cama e do sono e remete à isotopia do dormir que, como vimos, pode ser entendido como "suspensão das atividades da consciência".

O recurso discursivo usado para fabricar a ilusão de verdade nessa parte do texto em que se realiza o "encontro" entre Duccio e Paola é a delegação da palavra do narrador aos atores do enunciado: por meio de uma debreagem enunciativa de segundo grau, há um diálogo entre eles, através do qual se obtém um efeito de sentido de objetividade. Cria-se, assim, no co-enunciador a ilusão de estar assistindo a uma cena, de estar ouvindo as exatas palavras pronunciadas por eles. 
Depois da "confissão" da traição por meio do suposto pesadelo, a sanção parece positiva, porque Paola se mostra carinhosa com Duccio e até o agradece por ter chamado o sonho de pesadelo. Receber o carinho dela, após colocar o pecado em palavras, embora ele o conte como se tivesse sido um sonho, significa para ele aprovação. O sujeito permanece conjunto com o saber do seu pecado, mas tendo-o verbalizado, mesmo que sob a forma de um pesadelo, transforma seu estado tensivo: ele entra em conjunção com o alívio e logo dorme. Repete-se assim mais uma vez a figurativização do poder dormir para representar o abandono e a tranqüilidade.

Duccio adormece e "sai de cena". Ficam o quarto, onde toda a "cena" teve lugar, Paola com seus olhos e o narrador. Este descreve a pracinha "fora" do quarto e mostra como as luzes apagadas "fora" têm o efeito de deixar escuro o quarto "dentro": na escuridão apenas o narrador "vê" (e, portanto, pode descrever) os olhos de Paola que estão abertos e são "um pouco menos azuis" e "um pouco mais cinza".

Assistimos nessa última parte do texto a um deslocamento da perspectiva e o narrador, que até então viu e relatou, do ponto de vista de Duccio, numa focalização parcial interna, agora narra do ponto de vista de Paola e sabe muito mais do que antes parecia saber. O co-enunciador, num clássico exemplo em que é relevante pensar no seu contrato fiduciário com o enunciador, aceita as condições estabelecidas e recebe como "verdadeiro" esse saber que o narrador em terceira pessoa compartilha com ele.

Contar o pesadelo instaura uma manipulação que visa a obter um fazer crer: a traição é dita como se não fosse verdade com o objetivo de alcançar o convencimento. Paola aceita a 
manipulação apenas no modo do parecer e não no modo do ser. Instala-se a dúvida, representada metonimicamente pela cor "mais cinza" dos olhos, de que o pesadelo o seja apenas no modo do parecer, isto é, pode parecer um pesadelo, mas ser a verdade. É uma vez mais no jogo entre o parecer e o ser que a narrativa se constrói.

Passa-se, portanto, da confiança (crer ser) sobremodalizada pela categoria modal da certeza à dúvida e à insegurança (crer não ser): Paola, que antes acreditava na fidelidade de Duccio, agora não tem mais a mesma certeza: há a suspensão da possibilidade de qualquer juízo "verdadeiro" e elimina-se qualquer posição segura ou definitiva no plano do conhecimento. Com efeito, a dúvida situa-se numa posição intermediária entre a adesão fiduciária do crer e a adesão lógica do saber. Paola não crê mais na fidelidade de Duccio, porque o pesadelo poderia não ser o que parece (isto é, poderia ser uma traição "real”), mas também não sabe, ou seja, não adquire um efetivo saber porque a traição não foi confessada: a confiança e a relação fiduciária foram quebradas, mas a elas não se substituiu um claro e evidente conhecimento do "pecado" cometido pelo outro.

A quebra da confiança não produz como reação a revolta, ou seja, a ação de um sujeito que reage, mas, ao contrário, a tristeza e a decepção: o sujeito permanece na inação e na elaboração interior da "ofensa" recebida.

O conto começa e termina com a figura dos olhos que remetem a um "ser" que sente e que eles transformam. Presentes desde o título, são vistos apenas pelo filtro da imaginação: no início, Duccio imagina-os atrás das pálpebras, enquanto Paola está dormindo; no final, é o narrador que consegue vê-los abertos na escuridão do quarto. A figura dos olhos abre o caminho para que se 
depreenda a isotopia do "olhar", que atravessa o texto e lhe dá sentido. Em primeiro lugar, o conto é construído como se o narrador estivesse no mesmo lugar que os atores do enunciado e contasse uma cena que está "vendo", permitindo assim que o co-enunciador a "veja" também. Por outro lado, a recorrência de elementos ligados ao campo semântico do "visual" vai desde a repetição do verbo olhar (Duccio "olha" para Paola), até as contraposições visível vs invisível (ver o que não se pode ver e não ver o que está evidente) e /claro/ vs /escuro/.

Quanto à contraposição /claridade/ vs /escuridão/, observa-se uma redução progressiva da luminosidade (da semi-escuridão do primeiro parágrafo à escuridão do final) que representa uma "realidade" não decifrável porque não visível. Há, aliás, na luz do quarto e no azul dos olhos do final do conto um movimento análogo que é interessante observar: tanto num caso, quanto no outro a mudança parte do externo e vai em direção ao interno, ao espaço íntimo. É assim que o quarto "perde" a luz após a praça ficar escura, enquanto os olhos "perdem" o azul após saber do pecado.

Tanto a oposição entre claro e escuro, quanto a figurativização cromática, dada pelo azul e o cinza dos olhos de Paola, refletem as paixões de forma visual. Ao azul, que é a cor de um céu ensolarado e da água límpida e que representa serenidade e liberdade, contrapõe-se o cinza da tristeza e da decepção, criada pela "escuridão" do pecado, já que a cor cinza é do céu num dia chuvoso, mas também da melancolia e da indeterminação de algo que não é nem branco, nem preto. Aliás, por meio dessas duas cores podem ser resumidas todas as oposições significativas do conto: de um lado, o azul que remete à natureza, mas também à inocência, à claridade e à confiança e, do outro, o cinza com a referência à cultura, à culpa, à escuridão e à dúvida. 


\subsubsection{L'ONOREVOLE DOPPIACHANCE}

Buffo. Buffo essere nella stanza di un albergo di Palermo e vedersi in tv, mentre risponde alle domande dei giornalisti e degli spettatori. Un privilegio, in fondo. Come se il tempo e lo spazio offrissero sempre a quelli come lui una scappatoia. La possibilità, addirittura, di vivere una doppia vita. "Onorevole, come vicepresidente della commissione antimafia, cosa ritiene di aver realizzato, oltre a un rapporto di mille pagine che fotografa Cosa Nostra ma non la scalfisce?» Sorseggia un'aranciata amara e sorride ascoltandosi rispondere: sicuro di sé, sguardo deciso, ciuffo kennediano sulla fronte. "Innalzamento della guardia." "Denuncia senza rumore." "Faremo i nomi dei collusi." Funziona. Rielezione assicurata. Specialmente se $i$ voti glieli ha garantiti la famiglia. "Trentamila preferenze se ti presenti a Palermo con la patente di nemico numero uno delle cosche e ci cacci fuori dalle palle D'Ottavio.» Affare fatto. E adesso, qualche presenza di rito. Cena al Rotary, stasera. Si alza. Stringe il nodo della cravatta nera. In tv ne ha una rossa. Stacca di più. Doppia vita, anche tripla magari. Forse in questo momento una radio privata trasmette una sua intervista. E certo il capofamiglia non sa che lui $e$ D'Ottavio hanno un accordo.

«Onorevole, non teme per la sua vita?» sta chiedendo un giornalista. Esce dalla stanza lasciando la tv accesa per mantenere l'ubiquità. Un sicario gli spara nei corridoi dell'albergo e fugge.

La voce dallo schermo non si incrina: «Temo di più per le sorti dei valori che rappresento».

\section{O DEPUTADO DUPLA CHANCE}

Gozado. Gozado estar no quarto de um hotel de Palermo e assistir-se na tv, enquanto responde às perguntas dos jornalistas e dos espectadores. Um privilégio, no fundo. Como se o tempo e o espaço oferecessem sempre aos como ele uma escapatória. Até a possibilidade de viver uma vida dupla.

«Deputado, como vice-presidente da comissão antimáfia, o que o senhor pensa ter realizado, além de um relatório de mil páginas que fotografa Cosa Nostra ${ }^{34}$, mas não a arranha?» Ele toma lentamente uma laranjada amarga e sorri ouvindo-se responder: seguro de si, olhar decidido, cabelos na testa estilo Kennedy. "Aumento da defesa." "Denúncia sem barulho." "Vamos dar os nomes dos envolvidos." Funciona. Reeleição assegurada. Especialmente se quem garantiu os votos foi a famiglia. «Trinta mil votos, se você se apresenta em Palermo com o reconhecimento público de inimigo número um da cosca e tira D'Ottavio do nosso caminho.» Negócio fechado. E agora, algumas presenças obrigatórias. Jantar no Rotary, hoje à noite. Levanta. Aperta o nó da gravata preta. Na tv tem uma vermelha. Destaca mais. Dupla vida, até tripla, quem sabe. Talvez nesse momento uma rádio privada transmite uma entrevista dele. E com certeza o capofamiglia não sabe que ele e D'Ottavio têm um acordo.

«Deputado, o senhor não teme por sua vida?» está perguntando um jornalista. Ele sai do quarto deixando a tv ligada para manter a ubiqüidade. Um assassino de aluguel atira nele nos corredores do hotel e foge.

A voz do vídeo não se altera: «Temo mais pela sorte dos valores que represento».

\footnotetext{
${ }^{34}$ Lexemas ligados ao mundo da máfia foram deixados em italiano, pois em português eles são geralmente mantidos quando se fala desse tema.
} 
Pensemos, de início, nas possíveis leituras do título do conto: "L'onorevole doppia chance”. Joga-se nele com a justaposição do lexema onorevole e do grupo nom7inal doppia chance. Onorevole permite, ao menos, duas realizações semânticas: pode ser interpretado como adjetivo com o sentido de algo que dá, merece ou não prejudica a honra, ou então como substantivo na sua acepção de apelativo, também derivado de honra (onore), usualmente utilizado para interpelar os deputados do Parlamento Italiano ${ }^{35}$. Considerando, entre outras coisas, que onorevole ocupa a primeira posição, somos levados a dar-lhe o valor de núcleo principal e, portanto, de substantivo. Nessa leitura o grupo nominal "doppia chance" teria a função de modificador do elemento central e o significado do conjunto seria, então, "o deputado com duas chances" ou "o deputado que tem/teve/terá duas chances", querendo especificar mais. Está baseada nessa leitura a escolha da tradução "O deputado dupla chance", na qual se perde, no entanto, uma outra igualmente aceitável interpretação.

Com efeito, é plausível também considerar que o núcleo fundamental seja o substantivo chance e que o lexema onorevole deva ter a função de adjetivo modificador que junto com doppia constituiria uma dupla qualificação para o lexema chance. Lendo dessa forma, pode-se chegar a uma interpretação do título que levaria à seguinte tradução: “A honrosa dupla chance”.

É óbvio que a polissemia do lexema onorevole é a base para que se crie a possibilidade dessa dupla leitura, mas há, além disso, duas características próprias do sistema da língua italiana que permitem a ambigüidade e impedem que ela se verifique em português também: por um lado,

\footnotetext{
${ }^{35}$ As definições foram formuladas a partir dos dicionários Zingarelli e De Mauro.
} 
que o artigo definido para palavras que começam por vogal possui a mesma "aparência"36 para o masculino e para o feminino e, por outro, que o lexema onorevole, além de ser polissêmico, não possui uma terminação que imponha uma definição do gênero masculino ou feminino. É por isso que na tradução fomos obrigados a selecionar uma das duas leituras e decidimos por aquela que nos pareceu mais imediata, e também, porque menciona o ator principal do enunciado.

Será, contudo, na realidade contextual do discurso que as duas interpretações adquirirão sentido. Por enquanto, concentrar-nos-emos num aspecto que pertence a ambas: o duplo e a “dupla chance". Tanto pelo que diz, quanto pelo como o diz, toda a primeira seqüência do texto (antes da primeira debreagem enunciativa de segundo grau) introduz a isotopia da duplicidade, que será mantida até o final, assegurando coesão semântica ao discurso enunciado.

Comecemos pelo adjetivo com o qual se inicia o conto: buffo. Uma elipse, ou até mais que uma elipse: uma redução a um único adjetivo a partir do qual o co-enunciador é chamado a reconstruir o resto. A tarefa é facilitada pela reutilização do mesmo adjetivo no início da oração seguinte, que repete o lexema e o coloca num contexto. Há uma "reprodução" do pensamento de um ator, ainda não identificado, que "diz" duas vezes a mesma palavra, referindo-se à situação que está prestes a ser descrita. Na tradução usamos o adjetivo "gozado" que, como o lexema buffo do italiano, remete a algo estranho e curioso, mas recupera, ao mesmo tempo, a idéia do riso e do ridículo contida na palavra italiana. É nesse sentido que tê-la escolhido já é uma referência à duplicidade, se se considera que o riso contém duas faces e a contraposição de dois elementos: é justamente o inesperado que faz rir, aquilo que contraria as expectativas.

\footnotetext{
${ }^{36}$ Os artigos de partida são diferentes ( $L O$ para o masculino e $L A$ para o feminino), mas na elisão antes de palavras com vogal inicial chega-se em ambos os casos ao resultado $L^{\prime}$. A elisão não é sempre obrigatória, mas é sempre possível.
} 
É o riso popular rabelaisiano retomado por $\mathrm{Bakhtin}^{37}$ e é a relativização do cômico, a que se une o detalhe de que buffo indica também o ator ou o cantor que recebe um papel cômico na opera buffa, por antonomásia a obra popularizada e cômica, que se contrapõe, com sua força subversiva, ao tom sério. E é, ao mesmo tempo, o "riso ambivalente" de quem ri não só dos outros, mas também de si mesmo, que representa a segunda vida citada mais para frente no texto, quando se menciona explicitamente a possibilidade de viver uma "dupla vida" ("La possibilità, addirittura, di vivere una doppia vita").

É interessante observar, antes de concluir as reflexões sobre essa escolha do enunciador, que tanto o semema relativo ao riso e ao hilariante, quanto o que remete à representação teatral estão conservados também em português em palavras como bufonear ou bufão, que indicam a falta de seriedade, a representação cômica e ridícula e o fazer rir.

O conto abre-se com essas referências e continua sem indicar claramente um sujeito do enunciado, já que os dois verbos a seguir estão no infinitivo, que desobriga da necessidade de utilizar uma marca de pessoa e que posterga, dessa forma, a explicitação do ator principal. Além disso, o emprego do infinitivo confere vagueza ao enunciado e ressalta a ação em si, pois não dispensa apenas a indicação de pessoa, mas também a de tempo e de modo.

Temos dois predicados - "essere" ("estar", nesse caso) e "vedersi" ("ver-se") - e dois lugares - o quarto de um hotel em Palermo e a televisão. Descobre-se que os dois lugares são "paralelos" no texto, porque o que acontece é que alguém assiste a si mesmo numa entrevista

\footnotetext{
${ }^{37}$ Cf. BAKHTIN, 1987: 1-50.
} 
gravada e transmitida pela televisão: uma perfeita figurativização do desdobramento, do sair de si para se ver de fora.

A possibilidade de estar contemporaneamente em dois lugares e em dois tempos é manifestada explicitamente pouco depois quando se diz: "come se il tempo e lo spazio offrissero sempre a quelli come lui una scappatoia" ("como se o tempo e o espaço oferecessem sempre aos como ele uma escapatória"), ou seja, como se tivesse sempre para os "privilegiados" um outro tempo e um outro espaço, uma maneira de fugir, de percorrer caminhos alternativos. O lexema scappatoia que, como diz o dicionário, significa "expediente sutil e astuto para sair de uma situação difícil, perigosa ou embaraçosa" prenuncia a necessidade de "escapar" de um apuro por meio do tempo e do espaço. Nesse contexto discursivo, isso é mais uma referência ao desdobramento do sujeito: a solução é dada pela duplicidade espaço-temporal. Além disso, o uso de uma oração hipotética introduzida por "come se" diz e, ao mesmo tempo, nega, transferindo a leitura para o jogo entre o parecer e o ser e evitando afirmar claramente.

Quem fala nesse momento é o narrador em terceira pessoa que aqui se distancia do ator do enunciado, após ter no início apresentado sua voz fundida com a dele. Há, na verdade, movimentos de aproximação e afastamento do narrador em relação a esse ator do enunciado, introduzido ainda só vagamente, já que a impessoalidade do infinitivo esconde inicialmente o sujeito realizador. Um verbo em terceira pessoa dá o primeiro indício de sua presença, mas só com o aparecimento do pronome pessoal masculino "lui" é desvelado que se trata de um homem. Tudo isso produz um efeito de sentido de indeterminação e de suspense e estimula a prosseguir a leitura. 
O presente do indicativo introduzido e mantido como tempo principal da narração, além de criar a ilusão da fala em presença e o simulacro de que o narrado acontece simultaneamente à narração sendo atualizado a cada leitura, possui nesse texto específico una função peculiar: reforça a impressão de que tudo o que é contado esteja acontecendo ao mesmo tempo ou de que haja sempre, ao menos, duas ações realizadas contemporaneamente em dois lugares diferentes e paralelos.

Maiores detalhes sobre a 'identidade' do ator do enunciado chegam com a debreagem enunciativa de segundo grau, por meio da qual aparece na cena enunciada uma voz que faz uma pergunta ao ator principal. Não é possível determinar se a voz que questiona o deputado é de um jornalista ou de um espectador: nas primeiras linhas do conto ambos são mencionados e agora não há nada que especifique. O que sabemos é que essa "voz", referindo-se a ele, usa dois títulos: "onorevole" ("deputado") e "vicepresidente della commissione antimafia" ("vice-presidente da comissão antimáfia"). Nesse momento da narrativa é, então, revelado o papel social do sujeito, ou melhor, o duplo papel de representante eleito e de responsável pela luta contra a máfia. O sujeito camuflado no início pela forma infinitiva do verbo entra lentamente no espaço narrativo, mas se apropria dele e domina-o.

É necessária aqui uma "retroleitura" espacial, já que a introdução de referências relativas à máfia faz com que o topônimo Palermo mencionado no início adquira um novo sentido. Trata-se, com efeito, da cidade da Sicília considerada o centro da máfia, o lugar em que a máfia nasceu e não é, portanto, casual que tenha sido escolhida como cenário dos "acontecimentos". Palermo é mencionada duas vezes: no início diz-se que o ator do enunciado se encontra num hotel de 
Palermo e mais adiante, numa debreagem enunciativa de segundo grau que analisaremos a seguir, que nessa cidade o deputado vai se candidatar à reeleição.

Após a pergunta que aproxima o âmbito semântico da política e a esfera relativa à máfia, o lexema "onorevole" contido no título torna-se ainda mais significativo e manifesta-se como conector de isotopias. São realmente ao menos dois os sememas atualizados pelo contexto: confirma-se que "onorevole" é o deputado, mas, ao mesmo tempo, introduz-se uma isotopia temática e figurativa ligada à máfia (que será retomada ao longo do texto). A partir disso, justifica-se a interpretação proposta no começo, segundo a qual "onorevole" seria no título também o adjetivo derivado de "onore". Essa é, de fato, uma palavra-chave do universo de significação da máfia, como se pode facilmente concluir pensando em expressões como uomo d'onore, codice d'onore ou delitto d'onore, que a caracterizam e que remetem a aspectos essenciais de seu funcionamento.

Existem definições muito diversificadas de "honra". Considerá-la como "sentimento de merecer consideração e de manter o direito à própria estima", utilizando uma definição escolhida por Greimas (1983: 239), pode ajudar a entender melhor o que representa nesse contexto. Principalmente acrescentando a explicação que o mesmo Greimas dá desse sentimento, que “repousa numa avaliação positiva da própria imagem, isto é, afinal de contas, sobre uma ‘confiança em si’” (GrEIMAS, 1983: 239).

Pode-se dizer, então, que o núcleo isotópico do duplo, identificado anteriormente, rege e conecta as duas isotopias temáticas da máfia e da política e evidencia, aliás, um ponto essencial: 
o que importa aqui não são os dois âmbitos separados, mas sim as relações - duplas - entre eles, figurativizadas em primeiro lugar pelo ator do enunciado.

Observemos agora a pergunta feita ao deputado durante a entrevista a que ele está assistindo na tv. É reconhecível uma manipulação por provocação: constrói-se uma imagem negativa do deputado, que na função de vice-presidente da comissão antimáfia não realizou nada além de um longo relatório sem nenhum resultado concreto. A manipulação persuade o sujeito a responder justificando seu trabalho e ele, enquanto sujeito manipulado, passa a dever fazer. Deve desfazer a avaliação negativa enunciada na pergunta e defender-se da acusação de ineficiência.

Logo após a indagação e antes que o co-enunciador saiba como o programa narrativo vai continuar, isto é, se o deputado terá a competência necessária para a performance da "autodefesa", percebe-se a construção do sujeito como indivíduo consciente do "poder" que tem e acredita poder manter. A descrição mistura suas ações com sua aparência e transmite um efeito tensivo de relaxamento criado por elementos que constroem as paixões da segurança e da autoconfiança do indivíduo que quer e crê ser. O narrador descreve-o "seguro de si” e com um “olhar decidido", que em si já mostram a iteração do traço semântico da segurança, ainda reforçado pela descrição do que ele faz: bebe lentamente uma laranjada amarga como quem não tem ou não trai qualquer preocupação. O narrador diz ainda que ele "sorri ouvindo-se responder". Com essa cena de auto-regozijo do sujeito satisfeito de si mesmo e até exteriormente feliz com o que fez e com o que disse, completa-se o quadro da absoluta autoconfiança, do domínio da situação, do controle pleno do mundo dentro e fora de si. 
Vale a pena destacar que, enquanto no início é o infinitivo a forma nominal do verbo que dá o efeito de indeterminação, aqui é o gerúndio que se encarrega de conferir uma certa vagueza à oração, já que a uma frase gerundiva podem ser atribuídos vários sentidos com tempos, modos e valores diferentes. Nesse caso, a escolha do gerúndio "ascoltandosi" ("ouvindo-se"), que pode ser entendido como oração subordinada adverbial com o valor temporal de contemporaneidade (sorri enquanto se ouve responder), é muito menos determinado que a forma finita, pois esta última não deixaria espaço para outras interpretações, enquanto com o gerúndio se pode admitir também uma explicitação de tipo causal ou modal.

Mais um aspecto interessante é o uso dos verbos reflexivos. Tanto aqui (ascoltandosi, ouvindo-se), quanto no início (vedersi, ver-se) trata-se de verbos reflexivos de percepção que descrevem a atitude auto-referencial do sujeito percebendo a si mesmo: ouvindo sua própria voz gravada e vendo sua própria imagem na tela da televisão, ele reforça a figurativização da duplicidade, tendo, além disso, o duplo papel de quem "pratica" e de quem "sofre" a ação.

Antes de observar como o onorevole reage à manipulação, cabe fazer uma reflexão sobre um detalhe, que é parte da sua descrição. Para definir os cabelos na testa do deputado o enunciador escolhe o adjetivo "kennediano", instigando um leitor atento a uma reflexão sobre a razão que o levou a fazê-lo. Sem dúvida, é apropriado pensar que o adjetivo, proveniente do âmbito político, porque se refere ao ex-presidente norte-americano, se insira já por isso na isotopia da política reconhecida no texto. Mas há outros aspectos que a presença desse lexema traz para o texto: se é, por um lado, verdade que se associa a Kennedy o mito da juventude, da 
vitalidade e da abertura política, por outro, estudos mais recentes ${ }^{38}$ mostraram lados menos positivos da postura do político, definindo-o corrupto, mentiroso e sem senso moral, por terem descoberto seu envolvimento em guerras secretas e planos de invasão, além de seu contato com líderes do crime organizado. É com grande probabilidade justamente essa duplicidade que interessa no conto que estamos analisando, levando a traçar paralelos e similitudes entre Kennedy e a figura do deputado que ocupa o lugar central na narrativa.

Depreende-se, então, um sujeito que crê saber e poder responder ao questionamento feito e livrar-se de qualquer acusação que possa prejudicar sua imagem. As palavras da sua resposta são mostradas no texto por meio de um estratagema gráfico que garante um efeito específico: enquanto a pergunta está entre aspas angulares que são o sinal mais freqüentemente utilizado em italiano para identificar o discurso direto, as partes explicitadas da resposta estão entre aspas altas, o que manifesta uma diferenciação entre as duas debreagens. Pode-se interpretar a escolha do enunciador supondo a seguinte explicação: a voz que faz a pergunta é transcrita da maneira como a reproduz o simulacro da gravação televisiva no texto e, portanto, com o objetivo de criar a ilusão de que está colocada no texto "exatamente" como foi formulada e de que pode ser “ouvida" pelo co-enunciador; a resposta do deputado, ao contrário, é mostrada através do filtro de sua memória: trata-se de um sujeito que faz uma sorte de citação de si mesmo, repensando o que disse e selecionando as partes da sua resposta que considera mais relevantes. $\mathrm{O}$ co-enunciador pode "penetrar" nesse processo por meio do narrador que tem acesso a sua lembrança e pode acompanhar seu "fluxo mental”. Cria-se, dessa maneira, uma manifestação bastante peculiar de discurso indireto livre, em que aparece um narrador que se mistura com o pensamento do ator do

\footnotetext{
${ }^{38}$ Cf. REEVES, 1991.
} 
enunciado, mas também pode pôr entre aspas trechos do que ele está "pensando", separando, portanto, a sua voz da voz do outro.

Os três recortes selecionados mostram não só o tom da defesa, mas também quais elementos o deputado considera "estratégicos" para convencer o destinador-manipulador, isto é, para fazer crer. Eles tocam, de fato, em três aspectos essenciais para a opinião pública: a defesa da população "inocente", a denúncia e os nomes dos "culpados". Há uma reminiscência bélica na expressão "Innalzamento della guardia" (“Aumento da defesa”), que evoca a idéia de proteção e luta a favor da população; em seguida, é mencionada a "Denuncia senza rumore" ("Denúncia sem barulho") para indicar um fazer da Comissão antimáfia que denuncia, mas sem estardalhaço, sem mostrar; e, finalmente, diz-se "Faremo i nomi dei collusi" ("Vamos dar os nomes dos envolvidos"), com uma referência específica a quem fechou acordos secretos e ilegais com o crime organizado, como diz o dicionário para o lexema "colluso", e também com o aparecimento de um "nós" inclusivo, por meio do qual o ator do enunciado sinaliza que está falando por um grupo e não apenas por si mesmo. A comissão antimáfia da qual ele é vicepresidente é chamada para o discurso por meio do "nós" para que sejam transferidas ou, ao menos, diluídas as acusações e para que seja construída a "impressão" de que a voz não fala apenas por si. Aliás, o deputado evita cuidadosamente dizer eu (utiliza nominalizações ou a primeira pessoa do plural) criando um efeito de sentido de objetividade e de afastamento de qualquer responsabilidade pessoal. Além do "nós", essa última parte da resposta inclui também o uso do futuro do presente. Relativamente a esse tempo verbal Bertinetto afirma que: 
O futuro do presente possui caráter fundamentalmente perfectivo. O acontecimento por vir é, de fato, proposto, via de regra, em sua globalidade, e então mediante visualização do ponto terminal. ${ }^{39}$

A partir dessa reflexão, podemos considerar que o futuro cria aqui o efeito de sentido de "promessa" porque indica a intenção por parte de quem fala de realizar a ação indicada pelo verbo e, portanto, em quem ouve a convicção de que aquilo que é dito será cumprido.

Uma vez concluído o relato da "performance" a que chamamos de autodefesa, encontramos no plano do narrado a explicitação de uma sanção cognitiva. Confirmando a paixão da segurança identificada antes, manifesta-se uma avaliação certamente positiva: "Funziona. Rielezione assicurata." (“Funciona. Reeleição assegurada.”). Difícil é saber se quem assume o papel de destinador-julgador é o próprio deputado ou o narrador ou ambos, já que agora o discurso indireto livre não deixa marcas que permitam identificar ou separar uma voz da outra. São justamente a segurança e a autoconfiança, que antes no texto já definiram o deputado, os únicos elementos que podem guiar o enunciatário e ajudá-lo a decidir a quem atribuir essa avaliação da performance.

Seja como for, acontece que aqui é explicitado o objeto do programa narrativo principal: a reeleição que se configura como o valor da desejada conjunção. Nesse programa a manipulação por sedução é reflexiva: o sujeito, que precisa confirmar a representação positiva de si mesmo, se delineia como sujeito do querer e, por conseguinte, de busca. Como veremos, não há espaço para o dever ético, apenas o querer guia as escolhas, levando o sujeito a ter como único objetivo a

\footnotetext{
39 "Il futuro semplice ha carattere fondamentalmente perfettivo. L'evento a venire viene infatti proposto, di norma, nella sua globalità, e dunque mediante visualizzazione del punto terminale." (BERTINETTO, 1991: 120)
} 
conquista de sua meta. Envolve-se ele, então, em dois programas de uso por meio dos quais quer adquirir a competência necessária a realizar a conjunção com o objeto valor. Em se tratando de reeleição, competência significa garantir votos e apoio e é justamente com essa finalidade que o sujeito participa de dois acordos paralelos e incompatíveis: um com a máfia e outro contra a máfia.

Mas vejamos o que significa do ponto de vista narrativo estabelecer um acordo. Em primeiro lugar, para que o acordo se concretize, devem existir dois sujeitos envolvidos (que chamaremos $S_{1}$ e $S_{2}$ ), cada um dos quais em conjunção com um objeto que o outro deseja ou dotado da competência necessária para fazer o outro entrar em conjunção com esse objeto. Dado esse ponto de partida, a manipulação para que o acordo venha a realizar-se pressupõe que ao menos um dos dois sujeitos participantes - digamos $S_{1}$ - tenha um saber relativo ao desejo do outro e se configure, em seguida, como destinador-manipulador para convencer $\mathrm{S}_{2}$, ou seja, para fazer crer na sua confiabilidade. Levando em consideração que, para que o acordo possa ser fechado, $\mathrm{S}_{1}$ também deve crer em $\mathrm{S}_{2}$, é necessário que o contrato fiduciário seja "bitransitivo", isto é, que haja um crer recíproco entre os dois sujeitos. Eles devem agora passar à persuasão mútua (ao fazer fazer), de forma que tanto $\mathrm{S}_{1}$ quanto $\mathrm{S}_{2}$ realizem o que o acordo estabelece: numa relação que se tornou paritária, cada um deve dar algo para receber em troca aquilo que quer. Ambos são sujeitos de estado e de fazer e ambos crêem que o outro deva fazê-los entrar em conjunção com o objeto valor desejado. Criam-se, portanto, as condições para a realização daquilo que Greimas chamou "espera fiduciária" (1983: 229-230), que no caso do acordo também é recíproca. Isso significa que se configura a seguinte situação:

$S_{1}$ crê $\left[S_{2}\right.$ deve $\left.\rightarrow\left(S_{1} \cap O_{v}\right)\right]$ e, ao mesmo tempo, $S_{2}$ crê $\left[S_{1}\right.$ deve $\left.\rightarrow\left(S_{2} \cap O_{v}\right)\right]$. 
A plena realização dos programas leva à satisfação, para usar ainda as palavras de Greimas, mas é suficiente que só um dos dois sujeitos participantes não faça o estabelecido e quebre a confiança do outro para considerar não-realizados os programas e poder ter conseqüências que vão da decepção, no caso em que o sujeito reaja sem querer realizar uma ação de compensação da falta, à revolta ou à vingança, quando se instala um programa de liquidação da falta ${ }^{40}$.

No conto que estamos analisando a existência de um acordo é mostrada por meio de uma analepse que faz penetrar na cena narrada uma debreagem enunciativa de segundo grau "pronunciada" num momento anterior ao da narração. Retomando as palavras de Ricoeur, que observa algumas das finalidades desse procedimento, podemos dizer que nesse caso sua função é a "de completar a narrativa de um acontecimento situando-o à luz de um acontecimento precedente" (1995: 140), essencial para entender as frases colocadas logo antes: "Reeleição assegurada. Especialmente se quem garantiu os votos foi a famiglia." Uma voz que atribuímos, então, a um expoente da máfia traz para o presente da narração as palavras exatas da proposta feita ao deputado: ele teria trinta mil votos e, portanto, a "reeleição assegurada" candidatando-se em Palermo e assumindo publicamente o papel de "inimigo-mor" da máfia para eliminar D’Ottavio, um terceiro ator introduzido por meio de um antropônimo não mencionado em nenhum momento anterior do conto. É evidente seu papel actancial de anti-sujeito: deve-se tratar do "verdadeiro" inimigo da máfia, que a incomoda e que precisa ser "tirado do caminho" porque ele é contra a máfia e representa um perigo para ela.

A máfia apresenta-se, em primeiro lugar, como destinador-manipulador porque tem votos a oferecer ao deputado e quer dele uma "luta contra a máfia" feita apenas no modo do parecer que

\footnotetext{
${ }^{40}$ Cf. BARROS, 1990b: 66-67.
} 
faça parar quem tenta destruir seu domínio no modo do ser; mas, uma vez aceito o acordo, assume também o papel actancial de sujeito operador "parceiro" do acordo.

A proposta é feita através de uma oração condicional, em que a prótase (introduzida por "se") contém dois predicados no presente do indicativo indicando a proximidade e a "realidade" da hipótese colocada. Como já dissemos anteriormente, esse tipo de período hipotético é chamado em italiano della realtà, o que indica justamente sua "factualidade": o interlocutor acredita na realização da hipótese que enuncia e quer que o interlocutário acredite também. A apódose é elíptica porque renuncia à explicitação de sujeito frástico e predicado verbal e é constituída apenas pelo "objeto" oferecido pela máfia e desejado pelo deputado ("trinta mil votos"); além disso, contrariando a ordem mais freqüente, é colocada antes da prótase, de modo que recebe maior ênfase e aparece como o elemento principal da proposta.

Não há sujeitos ou verbos de dizer para introduzir o discurso direto, nem é identificada de outra forma pelo narrador a voz que propõe o acordo, mas o co-enunciador não duvida que se trate de um dos chefes da máfia, provavelmente o capofamiglia em pessoa (mencionado explicitamente só algumas linhas depois), trazido para o "presente da narração" com o seu tom de voz e o seu "corpo". No conto ele "fala" utilizando um modo próprio de dizer que na construção da linguagem remete a um modo próprio de ser. O discurso direto do representante da máfia é, de fato, uma parte que se insere na totalidade (totus) dos discursos da máfia e de seus membros, assim como entraram no nosso imaginário especialmente pelo cinema e pela literatura. $\mathrm{O}$ totus supõe: 
o mais-de-um, mas considerado do ponto de vista da semelhança, que implica um efeito de unidade, unus [...]. Desse eixo, totus/unus desponta o efeito de individuação, base do estilo. Desse eixo desponta o éthos constituinte do efeito de sujeito de uma totalidade. (DISCINI, 2003: 34-35).

O que temos aqui é, então, um recorte que remete a essa totalidade de discursos e que, inserindose no totus com características semelhantes, permite depreender o estilo e, portanto, o éthos do chefe da máfia. Ele "fala" e o co-enunciador tem a impressão de "ouvir" suas palavras, assim como elas foram pronunciadas e com a mesma carga de subjetividade. O simulacro de autenticidade e o efeito de sentido de realidade são reforçados pelo tom inserido em seu discurso, mas também pelas escolhas tanto no plano da expressão quanto no plano do conteúdo. Para falar com o candidato o expoente da máfia usa a segunda pessoa do singular ("tu”), que indica em italiano familiaridade e intimidade ou uma posição de superioridade, se interlocutor e interlocutário por seus papéis sociais deveriam usar o pronome de tratamento formal ("Lei”). Ele fala como quem não teme e não se submete a ninguém, como mostra o tom peremptório e autoconfiante que confirma também a imagem de quem exige e não pede; respeita os pactos porque defende sua própria honra e não tolera que os outros não façam o mesmo. Outro detalhe interessante é a frase "ci cacci fuori dalle palle D’Ottavio", que traduzimos com "você tira D’Ottavio do nosso caminho", por não termos encontrado uma expressão igualmente "forte" e chula em português para reproduzir a usada em italiano. Assim o chefe mafioso manifesta o que ele quer em troca dos votos: que o deputado se eleja e que D’Ottavio fique "fora” para não incomodar mais a máfia e os que dela participam. Aliás, o pronome na primeira pessoa do plural "ci" ("nos") indica justamente que o expoente da máfia representa o grupo e fala só por ele: é com a famiglia que o deputado faz o acordo. 
Após o fechamento das aspas, lê-se a confirmação de que o acordo foi aceito e a manipulação funcionou como demonstra a expressão: "Affare fatto" ("Negócio fechado"), mais uma vez num movimento de aproximação entre narrador e ator que não permite separá-los e atribuir o enunciado a um só dos dois. Há, portanto, um querer que, uma vez fechado o acordo, passa a ser também dever, pois existe uma "espera fiduciária" recíproca entre o deputado e a máfia, em que - como dissemos antes - cada um se compromete a um fazer para receber algo em troca e crê, portanto, que o outro o deva fazer entrar em conjunção com o objeto desejado.

A cena narrada volta agora para o quarto do hotel em Palermo, no qual o deputado se prepara para compromissos da sua agenda apresentados como rotineiros. "Qualche presenza di rito" diz-se no texto: presenças "obrigatórias", determinadas pelo "ritual" da campanha eleitoral à procura de apoio e votos.

Nessa parte do conto, as marcas "adesso", "stasera" e "in questo momento" ("agora", "hoje à noite" e "nesse momento") acusam uma debreagem enunciativa temporal e contribuem para ligar o texto à situação de enunciação, que se confirma com o uso difuso do tempo presente que, como já vimos, recupera o texto para o plano da enunciação e cria um simulacro de fala em presença.

Faz-se aqui também uso de elipses e frase curtas que criam um efeito de sentido de rapidez e indicam a presença de um enunciador de fôlego curto, que diz sem aparentemente deixar espaço para comentários. A voz do narrador parece imparcial: ele não toma partido e não se pronuncia a favor de nenhuma atitude ou contra elas, descrevendo "simplesmente" o que acontece e 
recuperando elementos anteriores à cena narrada apenas para completar o quadro e dar ao coenunciador o saber necessário para que ele possa entender os acontecimentos.

Há, porém, disseminados no texto, vários elementos que sinalizam uma avaliação do enunciador. Nesse trecho pode-se observar, por exemplo, a escolha de inserir um jantar no Rotary, para o qual o deputado foi evidentemente convidado e se prepara para ir. Mais uma vez, a decisão não pode ser considerada casual. O Rotary é um dos mais conhecidos clubes de serviço, que existe no mundo inteiro e reúne as elites das cidades com uma finalidade oficialmente filantrópica. Até aqui não reconheceríamos elementos associáveis às isotopias e às tematizações desenvolvidas no nosso texto. Acontece, porém, que é também notória outra função de clubes desse tipo, no interior dos quais se criam relações hierárquicas e de poder, além de um "natural" apoio aos associados, publicamente não declarado, que acaba muitas vezes decidindo o destino das cidades, de modo a influenciar a política e as decisões públicas. ${ }^{41}$

Chama a atenção também o detalhe da gravata do deputado. Ele levanta e, preparando-se para ir ao jantar do Rotary, aperta uma gravata preta, enquanto na imagem da televisão que é

\footnotetext{
${ }^{41}$ Os estudos sobre a máfia acabaram investigando suas relações com a maçonaria e também com os ditos clubes de serviço, como o Rotary. Um desses estudos publicou a opinião do ex-juiz de Palermo, Agostino Cordova, hoje procurador em Nápoles: "[...] É de todo óbvia a legalidade e a benemerência dos vários clubes de serviço, alguns dos quais reúnem as elites das cidades, ou seja, aqueles que ocupam os postos mais elevados da sociedade. Mas se de tal associação elitista, com objetivos perfeitamente lícitos e apreciáveis, passa-se àquela, pela qual parte dos membros utilizem, de forma oculta, suas funções a fim de concentrar o poder em suas mãos, cooptando para essa finalidade outras pessoas do mesmo meio e favorecendo em cada atividade aqueles que estão em volta do grupo, não me parece que se possa duvidar de estar em presença de uma associação secreta. No sentido de que são conhecidos os associados, mas desconhecidas as finalidades e as atividades." '[...] E' del tutto ovvia la liceità e la benemerenza dei vari club di servizio, taluni dei quali radunano le élite cittadine, e cioè coloro che occupano i posti più elevati della società. Ma se da tale associazione elitaria, avente scopi perfettamente leciti ed apprezzabili, si passa a quella forma di essa per cui parte degli aderenti usino occultamente le loro funzioni al fine di accentrare il potere nelle loro mani, cooptando allo scopo altre persone dello stesso giro e favorendo in ogni attività coloro che gravitano nel gruppo, non mi pare si possa dubitare che si sia in presenza di un'associazione segreta. Nel senso che ne sono noti gli associati, ma ignote le finalità e le attività." (FORGIONE/MONDANI, 1993: 242)
} 
transmitida ao mesmo tempo está usando uma gravata vermelha. Há até espaço para uma justificativa: "Stacca di più", "Destaca mais", como se a decisão de usar vermelho no programa de televisão tivesse sido tomada por razões unicamente "estéticas", ou seja, pelo parecer e não pelo ser. Tanto que agora a gravata pode ser preta, sem maiores problemas. Aparentemente. Não se pode, porém, evitar que entre em jogo a figurativização cromática ligada ao preto e ao vermelho, pois essas duas cores mobilizam redes associativas densas e contrapostas. Limitandonos ao campo da política, é impossível não pensar que, enquanto o preto remete, especialmente na Itália, aos camicie nere (camisas pretas) fascistas, o vermelho é a cor do socialismo e do comunismo.

Uma vez mais está claramente colocada a duplicidade, confirmada logo em seguida com a afirmação: "Doppia vita, anche tripla magari" ("Dupla vida, até tripla, pode ser") que até amplia a noção de duplo construída até esse momento, que agora se torna triplo. Para indicar essa hipótese de triplicidade é utilizada uma figura ligada à mídia. Até esse ponto, com o auxílio da imagem de um programa de televisão o enunciador construiu uma perfeita figurativização do desdobramento do ator do enunciado e agora ele coloca em cena também uma rádio, dizendo que “talvez" possa haver uma em algum lugar que esteja exatamente no mesmo momento transmitindo uma entrevista com o deputado, criando dessa maneira uma terceira voz que falaria no mesmo tempo em outro espaço.

É interessante notar que essa oração começa por "forse", "talvez" que é o único sinal de incerteza de todo o conto. Pela primeira vez, o narrador coloca-se como quem pode não saber tudo, fazendo duvidar de sua onisciência. Essa afirmação pode ser lida também como discurso 
indireto livre e, portanto, como se o onorevole também não soubesse ao certo de algo, mostrando uma primeira modalização pelo não saber.

Chegamos ao momento em que é revelado o segundo programa de uso. Isso acontece por meio de uma única frase: "E certo il capofamiglia non sa che lui e D'Ottavio hanno un accordo" (“E com certeza o capofamiglia não sabe que ele e D’Ottavio têm um acordo"). Essencial para entender e tentar analisar o desfecho do conto, esse elemento da "história narrada" aparece numa oração que inicia com "E certo" criando a ilusão de reproduzir o pensamento do deputado, inclusive por começar pelo conector coordenativo " $e$ " que gera a impressão de que aquilo que lemos está inserido no "fluxo" dos pensamentos do ator. Além disso, o efeito de sentido de certeza que esse início expressa se liga à imagem segura e autoconfiante do deputado que foi construída anteriormente.

Do pacto não são dados detalhes, mas mesmo sem explicitar seu conteúdo, nem como ou quando ele foi estipulado, a informação de que existe basta para pôr em cena uma estrutura polêmica. D'Ottavio que havia sido descrito e identificado como anti-sujeito, no acordo em que o deputado e a máfia se unem com um objetivo comum, passa agora a ter a posição de "parceiro" do deputado, enquanto a máfia é o anti-sujeito. Na perspectiva do deputado, o capofamiglia certamente não sabe e o acordo com D'Ottavio pode existir no modo do segredo: é, mas não parece. 
Os dois acordos podem ser visualizados da seguinte maneira:

\begin{tabular}{|l|l|l|l|}
\hline \multicolumn{2}{|c|}{$1^{\circ}$ ACORDO } & \multicolumn{2}{c|}{$2^{\circ}$ ACORDO } \\
\hline Sujeitos participantes & Anti-sujeito & Sujeitos participantes & Anti-sujeito \\
\hline Onorevole $\left(\mathrm{S}_{1}\right)$ & D'Ottavio & Onorevole $\left(\mathrm{S}_{1}\right)$ & Máfia \\
\hline Máfia $\left(\mathrm{S}_{2}\right)$ & & D'Ottavio $\left(\mathrm{S}_{3}\right)$ & \\
\hline
\end{tabular}

Vê-se que o onorevole aparece em ambos os casos como sujeito participante e, portanto, em situação instalada de "espera fiduciária" tanto com a máfia quanto com D’Ottavio, os quais, no entanto, ocupam posições contrapostas em cada um dos dois acordos: cada um desses sujeitos é participante de um acordo e anti-sujeito do outro. Isso implica, obviamente, a incompatibilidade dos dois pactos, especialmente se um dos outros dois sujeitos envolvidos souber da existência do "contrato rival".

A incompatibilidade é tanto maior se se considera que os dois sujeitos pertencem a universos axiológicos opostos e acreditam em valores que se anulam reciprocamente, já que um quer utilizar o poder da política para ser protegido nos seus negócios ilícitos, enquanto o outro quer usar os meios da política e da justiça para eliminar a ilegalidade da máfia.

Fica assim claro que, por um lado, há o sujeito onorevole fazendo um jogo duplo, na convicção de que os dois acordos poderão ser e não parecer e, portanto, coexistir. Afinal, seu objeto valor é a reeleição e para alcançá-lo está disposto a fazer tudo. Guiado pela intensidade do querer, que caracteriza o percurso passional da ambição, ele quer tanto ter quanto poder e não se põe limites para a realização de seu objetivo. Seu desejo, aspectualizado pelo excesso, não o faz 
ter medo. Mesmo agindo em não conformidade tanto com o dever fazer do grupo social dos políticos eleitos e dos candidatos a uma eleição democrática do qual faz parte, quanto com o dever fazer da máfia com a qual se alia, ele continua seguro de si e de suas escolhas, preocupado apenas com a realização do seu objetivo e não teme a sanção pragmática negativa que pode derivar do seu fazer.

O medo aparece explicitamente na última parte do texto numa pergunta ao deputado que desta vez sabemos ser de um jornalista: pergunta-se se ele teme perder a vida. É claro que nesse momento a referência é ao papel público de vice-presidente da comissão antimáfia, citado anteriormente. A indagação visa a conhecer o "estado de alma" do sujeito relativamente à eventualidade de ser "eliminado" pela máfia que sua atitude estaria incomodando. O medo de que se trata aqui é, portanto, diferente. Pode ajudar-nos novamente a já citada distinção feita por Fiorin entre o medo "derivado da possibilidade de uma sanção pragmática negativa (medo dissuasório)" e um outro tipo que é medo "de uma performance vista como ameaçadora" (1992b: $57)$.

Publicamente o deputado é o defensor da legalidade que está atacando a máfia e que, por isso, deveria temer suas represálias, ou seja, uma "performance ameaçadora" por parte dela. Isso é o que parece, mas o co-enunciador sabe que a situação é outra e que o deputado deveria ter medo de perder a vida como sanção pragmática negativa por não ter respeitado as regras impostas pela máfia (dever fazer) a partir do acordo feito com ela, que o obrigaria a respeitá-las.

Antes de ouvir a resposta do deputado, há mais uma descrição do que ele faz: sai do quarto e deixa a televisão ligada. Dizer que é o desejo de manter a "ubiqüidade" o motivo pelo qual o 
sujeito faz isso reforça mais uma vez a isotopia da duplicidade, essencial para identificar o sentido do final do conto.

Aliás, o percurso temático da duplicidade que se confirma no jogo duplo induz agora a uma leitura em direção ao duplo como falso, hipócrita e à duplicidade como "característica de quem se apresenta de maneira diferente do que realmente é; dissimulação, falsidade, fingimento", para defini-la com as palavras usadas pelo dicionário.

Entra em cena um matador de aluguel e atira nele nos corredores do hotel. A morte é o que a pergunta prenunciou e parece a conseqüência por ser ele oficialmente o candidato inimigo da máfia. O saber privilegiado do co-enunciador faz com que saiba que não pode ser esse o motivo da sua morte, que chega inesperada contra toda a segurança e a autoconfiança do deputado que crê nos acordos feitos e, principalmente, no seu poder fazer crer para construir o simulacro da confiança: ele acredita ter convencido e persuadido, isto é, levado ao crer e à confiança, todos os sujeitos dos quais "precisava”, do capofamiglia a D’Ottavio, dos eleitores aos jornalistas e, portanto, não prevê que poderia chegar uma sanção negativa.

No momento em que se diz “E certo il capofamiglia non sa che lui e D'Ottavio hanno un accordo”, a oração negativa escolhida pelo enunciador deixa transparecer o seu contrário, que é determinante para esse desfecho da história. Evidentemente o capofamiglia sabe do acordo com D’Ottavio e, portanto, a falta vem à tona e fere a honra da máfia. E a questão é que a incompatibilidade entre os dois acordos e a falta que disso resulta não são apenas de ordem juntiva, mas de ordem fiduciária que implica a relação de confiança entre dois sujeitos. $\mathrm{O}$ onorevole traiu a confiança da máfia com seu comportamento duplo e, portanto, terá de ser punido. 
Dissemos no início, que o código da máfia se baseia na honra, na "avaliação positiva da própria imagem" e na "confiança em si": ferir a honra da máfia ou tentar enganá-la, implica um castigo necessário, já que o homem de máfia e um uomo d'onore.

Após a falta fiduciária, instala-se, portanto, um programa de vingança com um querer e poder fazer para 'um PN 'humano', intersubjetivo, não concernente a um objeto de valor propriamente dito, mas a um outro sujeito" (GREIMAS, 1983: 240). Emerge um sujeito de fazer que procura a afirmação de si e a destruição do outro, para que seja defendida a honra ferida e instala-se a vingança como programa de reequilibração patêmica que deve compensar a falta provocada por meio de uma sanção pragmática, isto é, de um castigo, e de uma sanção cognitiva por meio da qual se possa mostrar quem é o verdadeiro herói.

A sanção pragmática é bem sucedida porque quem feriu a honra, morre. A sanção cognitiva não poderá realizar-se porque tanto o acordo, quanto a vingança acontecem, como já vimos, no modo do segredo porque não parecem, mas são. Ninguém além das duas partes envolvidas sabe dos acordos e, portanto, o deputado acaba morrendo como o herói que queria combater a máfia e foi morto por ela antes que pudesse começar. O deputado, que era o único que sabia, morre e os valores que ele representa estão salvos. A voz que, após ele ter sido assassinado, ainda se ouve sair pela televisão diz exatamente isso e confirma até o final sua imagem dupla.

É muito bem construída essa última parte do texto em que se "ouve" mais uma vez a voz que da televisão pergunta se o deputado não teme por sua vida. Sua resposta está desta vez entre aspas angulares, ou seja, com as palavras "exatas" que saem do aparelho televisivo. Quem fala agora é sua imagem duplicada: ele não pode mais "emprestar" e mostrar seus pensamentos. Sua 
voz gravada diz que ele não teme por sua vida, mas pelos valores que representa. De fato, ele não consegue salvar a sua vida, mas pode no modo do parecer proteger os "valores" da sociedade.

O assassinato interrompe o programa narrativo principal dado pela busca do sujeito de seu objeto valor e constitui um julgamento que tem o sentido de reforçar os valores e a orientação axiológica da comunidade na qual é praticado. A punição por ter feito um jogo duplo chega implacável e sanciona-o negativamente com a morte como instrumento de restabelecimento dos equilíbrios e dos valores

Aliás, a sanção pragmática que encerra o conto com a morte do onorevole pode ser lida como avaliação do enunciador que "mata" o vilão, mas também como a conseqüência necessária dos mecanismos e das "leis" da máfia, segundo os quais quem trai, precisa pagar com a morte.

Por mais que o enunciador não queira se expor nem por meio do narrador, nem por meio de julgamentos favoráveis ou desfavoráveis ao comportamento do deputado, o fato de ele concluir o conto com a sua morte é em si já uma avaliação e a manifestação de uma ideologia.

O deputado tem uma dupla chance no modo do parecer porque acaba como herói, mas não no modo do ser porque seu jogo duplo é descoberto e sancionado negativamente com a morte. Afinal, parece que os que são como ele têm sempre uma saída, mas não é assim. No entanto, mesmo não tendo escapatória, o castigo é ambíguo, porque é realizado, como se disse, no modo do segredo. 


\subsection{OSPOEMAS}

Os três poemas que analisaremos nas páginas seguintes são parte do cenário da poesia italiana contemporânea. Com essa "etiqueta" entendemos o que foi escrito em versos e em língua italiana nas últimas três ou quatro décadas, que é, portanto, um número bastante elevado de composições poéticas. Foram de grande ajuda as mais recentes publicações sobre a poesia italiana desse período $^{42}$, pois nos permitiram ter um panorama das principais vozes antologizadas e nos auxiliaram, portanto, na seleção dos textos a serem trabalhados em sala de aula e propostos aos alunos.

Os poemas escolhidos pertencem aos últimos trinta anos do século $\mathrm{XX}$ e os poetas são Giorgio Manacorda, Patrizia Cavalli e Sebastiano Vassalli, que escrevem e publicam poesia ainda hoje.

Muitos perguntam-se se é possível dizer que existe poesia na atualidade e essa preocupação não é de hoje: volta insistentemente pelo menos desde o início do século passado. Basta pensar que é, por exemplo, de 1929 uma entrevista com Giuseppe Ungaretti intitulada "A poesia contemporânea está viva ou morta?" ${ }^{43}$ publicada na revista L'Italia letteraria, na qual se discute justamente esse tema. A posição de Ungaretti, por mais que possa parecer crítica e dura em

\footnotetext{
${ }^{42}$ Utilizamos em especial as seguintes obras: o capítulo de atualização sobre a poesia italiana contemporânea escrito pelo crítico literário Alfonso Berardinelli e publicado em 2001 na Storia della letteratura italiana [História da literatura italiana] da editora Garzanti; a antologia poética organizada em 1975 pelo mesmo Berardinelli e por Franco Cordelli, reeditada com importantes atualizações em 2004 com o título Il pubblico della poesia. Trent'anni dopo [O público da poesia. Trinta anos depois]; e mais uma antologia poética preparada pelo crítico e poeta Giorgio Manacorda (também um dos poetas que escolhemos aqui) e publicada também em 2004 com o título La poesia italiana oggi [A poesia italiana hoje].

${ }^{43}$ A tradução para o português dessa entrevista foi publicada em 1994 no livro Razões de uma poesia, organizado por Lucia Wataghin.
} 
alguns momentos, revela o que o simples contato com os textos poéticos nos diz: a poesia existe pelo fato de que dela se fala e de que existem poetas que dão um "testemunho sincero e preciso do drama e da tragédia do nosso tempo" (1994: 85). O que aconteceu foi apenas que mudou. E continua mudando desde então.

A "regra" e a "transcendência", que durante séculos foram elementos essenciais da poesia, não a caracterizam mais. À regularidade do ritmo e da métrica substitui-se um aparente "caos" ao qual se dá o nome de verso livre, enquanto a cotidianidade dos temas e o prosaico tomam o lugar da "aura" da poesia do passado.

Há, ao mesmo tempo, tensões e projetos poéticos como reconheceu o mesmo Ungaretti, que, na mencionada entrevista, a propósito do seu tempo, afirma:

\begin{abstract}
Não lembro mais quem foi, mas alguém dizia, e dizia bem, que a poesia moderna se propõe pôr em contato o que está mais distante. Maior a distância, superior a poesia. Quando tais contatos produzem luz, atinge-se a poesia. Em poucas palavras, uso, e talvez abuso, de formas elíticas. Como o senhor vê, também a poesia hoje corre atrás da velocidade. Digo-lhe mais: Leopardi que sabia tudo com antecedência, em algumas reflexões exatamente sobre a velocidade, e sobre a música, não condena os esforços dirigidos para uma libertação musical da palavra. Chegará a poesia a possuir algum dia um instrumento que permita ao espírito manifestar-se como quiser? Mas não chamaria de estultos os esforços de quem têm tanta ambição (UNGARETTI, 1994: 81-82).
\end{abstract}

Por um lado, então, o desejo e a necessidade de elipses e metáforas que possam aproximar elementos aparentemente separados; por outro, a questão da "libertação" da palavra. Voltamos assim ao assunto do já citado verso "livre". 
Geralmente usa-se essa definição para indicar uma maneira de fazer poesia em que predomina justamente a liberdade, a possibilidade de não seguir rígidos esquemas métricos e rítmicos, de não se submeter a um verso, cujo comprimento e cujo ritmo são pré-estabelecidos. Agora o fato é que um verso realmente "livre" não existe. Talvez possamos falar de verso irregular, no sentido de que não são reconhecíveis regras rítmicas e métricas, mas não de falta total de "regras". Percebemos que um poema respeita sempre um ritmo musical porque este corresponde a um "projeto sonoro" do poeta, o qual cuida dos efeitos de sentido que o jogo com a sonoridade produz.

Embora a questão seja enfrentada e resolvida de maneiras distintas, notamos, de fato, nos três poemas analisados que a preocupação com a sonoridade, com o ritmo e com aquela parte do sentido que é construída no plano da expressão, gerando significativas transformações, continua ocupando um lugar de relevo. Os acentos tônicos com seu lugar essencial na métrica italiana, mas também as assonâncias, as aliterações e até a rima desempenham um papel importante no processo de constituição do sentido do texto, ao qual os poemas não renunciam.

Observa-se uma tendência à condensação - particularmente evidente em alguns casos, menos em outros - de forma que se mostra um éthos que ao dizer pouco e ao concentrar figuras num "espaço restrito", obriga o co-enunciador a preencher as elipses predicativas graças a sua competência discursiva e interdiscursiva, restituindo mesmo as informações específicas que o texto não dá. O leitor deve, portanto, ocupar um lugar e realmente "co-construir" o sentido do texto, cuja "falta" pode ser compensada pela sua presença. 
Eis o outro aspecto de que fala Ungaretti: a poesia procura aproximar universos e palavras aparentemente tão distantes que não poderiam encontrar-se, mas o fazem no texto poético, o lugar em que são permitidos "saltos" e rupturas e em que a língua pode manifestar o seu “excedente" de sentido.

Vejamos agora por que citamos a "transcendência". Partimos da idéia segundo a qual tradicionalmente se considera que a poesia, embora mantenha uma relação com a "realidade" sensível e com a experiência humana, as ultrapassa, conseguindo representar significados tão universais que superam todas as categorias dadas e que lhe conferem uma sacralidade e uma aparência "superior".

Acontece que isso parece inconciliável com a "cotidianidade" presente na poesia contemporânea e com o "rebaixamento" dos temas tratados, até explicitamente tematizado no terceiro poema, cujo tema é justamente o "lugar" da poesia. Pode a poesia permanecer tal mesmo preenchendo seus versos com uma lista de produtos do supermercado? E pode afirmar-se que é poesia aquela que não usa palavras misteriosas e enigmáticas, baseando-se, ao contrário, no simples e no aparentemente prosaico?

A experiência do indivíduo continua sendo transmitida e se transforma em universal, mesmo na aparente banalidade.

Os efeitos de distanciamento e de ironia obtidos por meio do "rebaixamento" do registro são maneiras para mostrar a frieza do mundo atual. Esse é, aliás, um aspecto que os três poemas têm em comum: a representação da falta de emoções fortes, da ausência da intensidade. Por meio 
de uma relação amorosa (concretizada no primeiro poema e imaginada no segundo) ou por meio de um poema, cujo tema é a própria poesia, os textos descrevem a sociedade de massa e as relações regidas pelas leis do consumo. O quadro que revelam é de uma presença generalizada da paixão da indiferença, do "não querer nem bem nem mal", que se delineia como característica da contemporaneidade.

Quem diz tudo isso é sempre uma primeira pessoa, já que, respeitando-se as coerções do gênero lírico, há sempre um $e u$ que fala. $\mathrm{O}$ enunciador constrói a ilusão de coincidir com o $e u$ que aparece no texto e mostra-se, portanto, na forma típica do poema que é a debreagem enunciativa, por meio da qual se cria o simulacro da enunciação. No entanto, deve-se considerar sempre que:

a reprodução das condições do ato da enunciação no interior do discurso terá sempre um valor de metáfora em relação à enunciação de fato (que, por sua vez, será sempre pressuposta). (TATIT, 2001: 104)

O eu domina o discurso poético tanto que para Authier-Revuz:

Dois tipos de discurso [...] não apresentam, tendencialmente, marca alguma de heterogeneidade mostrada: o discurso científico e a escritura poética. De maneira oposta, ambos testemunham uma ruptura com essa modalidade "normal" do discurso, que articula a heterogeneidade mostrada à heterogeneidade constitutiva, no modo da denegação ${ }^{44}$.

A estudiosa diz ainda em seu texto que se trata de discursos "monológicos" que eliminam por conta disso todas as marcas do outro, denegando a realidade da heterogeneidade constitutiva

\footnotetext{
44 "Deux types de discours [...] ne presentent, tendanciellement, aucune marque d'hétérogénéité montrée: le discours scientifique et l'escriture poétique. De façon opposée, ils témoignent tous les deux d'une rupture avec cette modalité 'normale' du discours, qui articule l'hétérogénéité montrée à l'hétérogénéité constitutive, sur le mode de la dénégation" (1982: 146).
} 
presente em todos os discursos - já que, como sabemos, nenhuma palavra é neutra - e dissimulando no discurso qualquer manifestação explícita da sua efetiva heterogeneidade.

Interessante é, porém, que, contrariando desta vez as coerções de gênero, os três poemas que apresentamos aqui não seguem essa "norma" citada por Authier-Revuz. Todos incluem o outro no corpo do texto e apresentam ao co-enunciador de forma mostrada e marcada a consciência de sua não-homogeneidade. O discurso direto, assinalado por meio de aspas ou travessão, estimula no enunciatário uma leitura que procure não apenas no texto, mas também fora dele, as referências necessárias para que sejam construídos sentidos. A voz do outro "ouvese" separada da voz do eu, que permite que ele penetre seu espaço e que participe da construção do sentido, mas ao mesmo tempo relega sua fala a um lugar isolado e nitidamente distanciado, marcando a ruptura entre ele e o mundo exterior. 


\title{
1.2.1. HA PARTORITO-Giorgio Manacorda
}

\author{
Ha partorito, \\ sono partito, \\ sono andato all'ospedale: \\ "Come va?» \\ «Non c'è male» \\ L'ho sposata. \\ "Come è andata?» \\ «E andata \\ via». Allora \\ l'ho sposata ancora. \\ "Come va?» \\ «Va». Ma \\ ho lasciato anche lei, \\ parto alle sei.
}

Pariu,

parti,

fui ao hospital:

"Como vai?"

"Nem bem, nem mal."

Casei com ela.

"Como foi?"

"Foi

embora." Então

casei com ela de novo.

"Como vai?"

"Vai". Mas

deixei ela também,

parto às seis.

(Giorgio Manacorda, Soldato segreto, 1999) 
Desde a primeira leitura do poema, chamam a atenção a brevidade no dito e a condensação no modo de dizer. O enunciador escolhe dizer pouco e com versos breves e prefere a rapidez e o implícito, não mostrando as relações, renunciando quase sempre aos conectores e reduzindo ao mínimo a "narração". Cabe ao enunciatário explicitar liames só indiretamente apontados e completar o texto, utilizando o implícito que ao dizer pouco diz muito.

O poema é, de fato, constituído por uma única estrofe de catorze versos heterométricos. Pode ser reconhecida uma prevalência de pentassílabos ${ }^{45}$, mas os pequenos versos chegam a ter apenas duas sílabas (verso 12) não propiciando que o conteúdo seja desdobrado em todas as suas conexões, tal como o permitiria, por exemplo, o soneto, bastante apto ao jogo intelectual. Numa composição poética como essa ocorre, ao contrário, uma "simplificação do conteúdo" e o sentido é obtido por meio da força das palavras, selecionadas de modo que possam conter e indicar caminhos de leitura.

Não há sempre "rimas perfeitas" no poema que estamos analisando, mas podemos identificar uma atenção para com as sonoridades que contribui para uma leitura rítmica e cria o efeito de ligar as partes da composição. É assim que o texto, não tendo outras segmentações evidentes, manifesta sua estruturação. Os versos estão quase todos ligados dois a dois por rimas ou assonâncias. O jogo de "duplas" não é, porém, regular. Enquanto o primeiro e o segundo verso são ambos particípios passados dos verbos partorire e partire que produzem partorito e partito dos quais resulta uma rima, o mesmo não acontece com os versos que seguem, já que o terceiro se une ao quinto (ospedale/male), mas a mesma coisa não se realiza com o quarto e o sexto: o

\footnotetext{
${ }^{45}$ Note-se que, em italiano, para determinar o tipo de verso, se considera também a sílaba átona final.
} 
quarto fica isolado e o sexto cria um conjunto com os dois seguintes, todos particípios passados de primeira conjugação (sposata/andata/andata), dois dos quais idênticos entre eles. Os últimos seis versos jogam de novo com a união de "duplas" e temos assim allora/ancora; va/ma; lei/sei.

Comecemos observando os primeiros dois versos que introduzem elementos essenciais para a nossa análise: Ha partorito, / sono partito. Há uma terceira pessoa no verso 1 (um outro) e uma primeira no verso 2 (um eu), de forma que identificamos logo de início a oposição semântica fundamental /identidade/ vs /alteridade/, que é completada pelas categorias /masculinidade/ vs /feminilidade/, reconhecíveis a partir da "semântica" e da "gramática" contidas nos versos. O feminino (ela) do primeiro verso é determinado pela própria natureza do verbo partorire (dar à luz, parir), que pressupõe um sujeito operador mulher; enquanto o masculino do $e u$ do segundo verso é definido gramaticalmente, já que o tempo verbal do predicado (passato prossimo) requer em italiano que seja explicitada na desinência do particípio passado a concordância em gênero e número com o sujeito, caso o verbo seja - como acontece com partire - do tipo que, nos tempos compostos, deve ser conjugado com o auxiliar essere $^{46}$. Sono partito indica, então, com certeza um sujeito masculino, que se reafirma no verso a seguir em que se diz sono andato, utilizando mais uma vez a mesma estrutura.

Além disso, observamos o paralelismo na colocação dos verbos partorire e partire, pois ambos estão no passato prossimo e em versos constituídos por apenas auxiliar e particípio passado. Isso contribui para que seja evidenciada desde o início a analogia entre os dois lexemas

\footnotetext{
${ }^{46}$ Não é muito fácil indicar regras precisas sobre o uso do auxiliar nos tempos compostos em italiano, tanto que há gramáticos que, não conseguindo outra maneira de resolver a questão, elaboraram listas com os verbos a serem conjugados com essere ou avere. O que se pode dizer é que com os reflexivos e intransitivos pronominais e com quase todos os impessoais é preciso usar o auxiliar essere, assim como com a maioria dos verbos intransitivos, em particular aqueles que indicam movimento e permitem que seja indicado o destino ou a proveniência, bem como com os inacusativos e os ergativos. (Cf. SERIANNI, 1997: 276-277 e SALVI, 1988: 47-49)
} 
que será utilizada, como veremos, no final do texto. Com efeito, percebe-se não só sua parcial homofonia dada pela repetição das mesmas consoantes (as oclusivas surdas /p/ e / $/$ e a vibrante /r/) e das mesmas vogais - com exceção do /o/ - , mas também a possível proximidade semântica entre partorire, que indica o nascimento, mas também a separação entre a mãe e o recémnascido, e partire, que se refere à separação de algum lugar ou de alguém, mas pode instituir analogia com o renascer, se pensarmos que a mudança de lugar e a viagem podem ser momentos em que a vida de um indivíduo recomeça.

Está assim posta também a oposição categorial /união/vs /separação/, confirmada a seguir pelo aparecimento dos lexemas sposare e lasciare que convocam a oposição /conjunção/ vs /disjunção/ ligada ao campo das relações homem-mulher, figurativizadas aqui na vida de casal e nas fases de sua evolução assim como são estabelecidas pela sociedade e pelos vínculos que ela impõe. Não são mencionados os "sentimentos", mas sim o casamento, a separação e o nascimento de um filho, manifestando-se assim somente o lado "exterior" de um relacionamento amoroso.

Por meio da contraposição /união/ vs /separação/, são inseridos no texto também os movimentos de aproximação e afastamento e, por isso, as categorias perto e longe, dadas pelos predicados partire e andare (via), que indicando a distância e o afastamento implicam também seus contrários, além de remeter à direcionalidade, constituindo assim o elemento espacial do poema, que se desenvolve praticamente "sem lugar" (o único espaço expressamente citado é o hospital) e poderia então acontecer em "qualquer lugar". 
O poema inicia, como vimos, com o discurso embreado do $e u$ que introduz em primeiro lugar uma terceira pessoa (ela) e se mostra depois como eu narrador e ator principal do enunciado. Começa desde o primeiro verso uma sorte de "narração", ou melhor, a descrição de performances reduzidas, na maior parte das vezes, a apenas um predicado. O poema segue nessa narração sempre as mesmas características, mostrando performances de um eu sujeito operador com um tempo que é sempre o passato prossimo. As exceções são dadas apenas no primeiro e no último verso: o primeiro verso mantém o tempo verbal e muda o sujeito (ela), enquanto o último continua com o mesmo sujeito operador, que age, porém, num tempo presente.

Já dissemos nas análises anteriores que o passato prossimo possui em italiano características parecidas às do passé composé do francês, com tanta perspicácia estudado por Benveniste (2005: 260-276). O que nos interessa aqui é, por um lado, que a escolha desse tempo verbal implica uma perfectividade, ou seja, diz que, na perspectiva a partir da qual se vêem, as ações são colocadas como já terminadas, com um início e um fim determinado, sem extensão durativa e fazendo a narração "andar para frente". Por outro lado, o passato prossimo indica que o passado do texto é anterior em relação ao momento da enunciação, o que significa que está ligado ao presente implícito e atualiza as ações, mostrando-as como tendo relevância para o momento presente e dizendo, portanto, de que maneira se posiciona o narrador em relação a elas.

As ações acontecem sem aparente manipulação: é "a razão que não tem razões" e parece movida pela paixão da indiferença, que não quer fazer nem bem, nem mal (cf. BARROS, 1990b: 68-69). São narradas várias performances (pariu, parti, fui ao hospital, casei, casei de novo, deixei-a, parto): trata-se, por um lado, das performances físicas do sujeito manifestadas na transferência para um outro espaço (partire/andare) e, por outro, das transformações juntivas 
(sposare/lasciare) que mostram as mudanças na relação com o objeto-valor. São todas ações pragmáticas do eu apresentadas de modo a transmitir a predominância de uma a-foria, isto é, de uma neutralidade, que, não mostrando a tensão do sujeito nem para o bem, nem para o mal, confirma a sua “paixão sem paixões”. Não há euforia ou disforia, não há axiologização positiva ou negativa, não há - aparentemente - nenhuma ligação com um mundo de valores. As pessoas (aqui um homem e uma mulher) agem (têm um filho, casam, se separam), mas sem que se manifestem "estados de alma".

O mundo ordenado e categorizado deu lugar a um mundo sem orientação, nem finalidade: os atores agem com indiferença e a indiferença está no poema como representação da contemporaneidade, na qual a efemeridade das relações entre sujeitos produz relações amorosas que se quebram facilmente e sem razão aparente.

Interessante a esse respeito é a maneira como são colocados o "segundo" casamento e a sucessiva separação. O texto diz "Allora/l'ho sposata ancora” ("Então/casei com ela de novo") e, após uma troca interlocutória, "Ma/ho lasciato anche lei" ("Mas/deixei ela também"), não deixando claro se se está falando do mesmo ou de um outro sujeito, apresentado aqui como objeto-valor. Esse modo de dizer é escolhido para mostrar que:

[...] não há mais espaço para as diferenças individuais: o outro não pode ser verdadeiramente considerado como um objeto-valor, pois o que é valorizado, é a própria situação, o fato que o mundo gratifica o sujeito, reduzindo-se o outro a esse mundo funcional.

E ainda: 
o outro não faz diferença, ele participa de um estatuto imaginário no qual o seu comportamento é previsível e previsto; é um simulacro interno ao programa do sujeito indiferente. ${ }^{47}$

Esse sujeito indiferente é um sujeito competente do fazer, um eu que sabe e pode ir e vir, juntar-se (casar) e separar-se (deixar): é o eu masculino que determina os movimentos do texto e é o sujeito operador de quase todas as performances.

Acontece, por exemplo, que para indicar o casamento não foi escolhido o verbo reflexivo sposarsi (casar-se), cujo uso é sem dúvida dominante hoje em dia para sublinhar a relação paritária que existe entre o homem e a mulher, mas sim a versão transitiva sposare (casar) + objeto direto. Essa alternativa, certamente mais rara, a menos que não se queira obter um específico efeito de sentido, produz o resultado "l’ho sposata", em que se deduz a relação do sujeito-operador-homem com o objeto-mulher colocada no texto. Como no início, a oposição /masculino/ vs /feminino/ é dada tanto pela semântica, quanto pela gramática: o eu masculino casa com um ela (feminino), cujo gênero transparece claramente explicitado por meio da desinência do particípio passado, já que em italiano, quando o passato prossimo é precedido por um pronome direto, precisa concordar com ele em gênero e número.

Consideramos até agora apenas a parte do texto que chamamos "narração", mas, após os três primeiros versos que expressam, como vimos, performances acontecidas num passado do

\footnotetext{
47 "[...] il n'y a pas non plus de place pour les différences individuelles: l'autre ne peut être véritablement considéré comme un objet-valeur car ce qui est valorisé, c'est la situation elle-même, le fait que le monde gratifie le sujet, l'autre se réduisant à ce monde fonctionnel."

"[...] l'autre ne fait pas différence, il participe d'un statut imaginaire dans lequel son comportement est prévisible et prévu ; il est un simulacre interne au programme du sujet indifférent." (MARSCIANI, 1984: 30)
} 
discurso que é, portanto, enunciativo, é introduzida por meio dos dois pontos e das aspas uma debreagem enunciativa de segundo grau.

Percebemos a partir desse ponto que o texto pode ser dividido em duas partes, separadas até graficamente de forma muito clara: três vezes ao longo do poema as performances são interrompidas pelo discurso direto, mostrando e marcando por meio das aspas angulares a intervenção de uma voz que fala e se faz ouvir.

Não há verbos de dizer que dêem indicações sobre quem fala. Há apenas uma voz que pergunta três vezes, jogando com a polissemia do verbo andare. Esse verbo, utilizado no terceiro verso no sentido de deslocar-se de um lugar para o outro (no caso em questão "ao hospital"), indicando movimento, afastamento e separação, assume nas duas perguntas colocadas no presente do indicativo ("Come va?") o sentido de proceder, desenrolar-se referido às coisas da vida (estado de saúde ou de espírito, trabalho, etc.) e é usado quando alguém mostra interesse por outrem, enquanto colocado no passato prossimo ("Com'è andata?”) indica que se quer saber o êxito de alguma coisa, como algo "acabou". Isso implica que o mesmo lexema pode pressupor tanto um movimento, quanto um estado e contrapõe, portanto, /dinamicidade/ vs /estaticidade/.

Os questionamentos introduzidos no texto são, na verdade, pedidos de sanção cognitiva: após o parto, após o primeiro casamento (pergunta no passato prossimo), após o segundo casamento. $\mathrm{O}$ interlocutor solicita uma sanção cognitiva positiva ou negativa e recebe uma sanção neutra que quebra a expectativa. Na primeira e na terceira ocorrências, nas quais as perguntas são feitas no presente do indicativo, as respostas são respectivamente "Non c'è male" e " $V a$ ", ambas indicando uma avaliação dos acontecimentos que não é nem eufórica, nem 
disfórica. Confirma-se dessa maneira que não se diz nem para o bem, nem para o mal, já que a resposta em negativo ("Non c'è male") põe em cena ambos e nenhum dos dois, fazendo novamente referência à indiferença.

As três perguntas em discurso direto presentes no poema instalam uma interlocução entre um $e u$ e um $t u$ pressupostos que, porém, não aparecem (o $e u$ dá a voz a um segundo $e u$ que não diz eu), já que tanto a pergunta quanto a resposta utilizam a terceira pessoa (falam de situações e/ou de terceiros) e assim o eu e o tu não se mostram. Aliás, é justamente o jogo entre o impessoal e o pessoal um dos elementos mais interessantes nessas debreagens.

A impessoalidade dos predicados das perguntas colocadas não necessita da explicitação do $e u$ e deixa indefinido o interlocutor, que no primeiro caso poderia ser o eu dos dois versos anteriores em relação direta com ela também citada no início, embora nada exclua que possa ser também um terceiro sujeito que pergunta sobre a situação (talvez o narratário transformado em interlocutor), ou ainda o mesmo eu que sai de si e pergunta como se fosse um outro.

A segunda interrogação está mais claramente definida pelo contexto e é mais evidente que entra em cena um outro sujeito. Podemos pensar que se trata de um segundo interlocutor ou então do mesmo, que novamente solicita uma sanção cognitiva. De imediato lê-se, como no primeiro caso, uma sanção aparentemente neutra, que se transforma depois em sanção negativa, indicando uma ruptura (é andata/via, foi/embora). O jogo com a polissemia do verbo andare, iniciado nos versos anteriores, amplia-se aqui pelo uso da locução verbal formada pelo verbo andare e pelo advérbio via, que altera o valor sêmico do predicado. Isso fica ainda mais evidente se considerarmos que "é andata/via" está aqui como resposta à pergunta "Com'è andata?" ("Como 
foi?"). De fato, a essa interrogação pode-se responder dizendo simplesmente " $E$ andata” ("Foi") para indicar algo que não teve um desenvolvimento ou um final nem particularmente satisfatórios, nem especialmente decepcionantes. Isso significa que a resposta poderia terminar aqui e o final do verso, provocando uma pausa no ritmo da leitura, além de uma interrupção na linearidade do texto, induz num primeiro momento a pensar que seja assim. No verso seguinte aparece, no entanto, a ruptura inesperada e a resposta transforma-se, mudando tanto o sentido, quanto o sujeito operador e tornando-se, entre outras coisas, inadequada à pergunta colocada. Aparece o inesperado que subverte a fixidade e a "lógica" e o "fim do casamento" é representado também semi-simbolicamente pela quebra dos versos. Trata-se de ironia e auto-ironia e de uma situação em que o duplo, o inesperado, o jocoso parecem esconder o mal-estar do sujeito.

Chegamos à terceira inserção de discurso direto que repete o mesmo esquema. Utiliza-se mais uma vez o presente do indicativo que, como dissemos, leva a uma interpretação da pergunta pela qual se quer saber como está se desenvolvendo algo que ainda não terminou - nesse caso, o segundo casamento - e a resposta é mais uma vez neutra.

Vale a pena observar que as performances narradas após os três questionamentos não se apresentam como tendo relação com o que é perguntado, mas, se no primeiro caso não é estabelecida uma relação de causa e efeito entre o discurso direto e verso subseqüente, nos outros dois a presença dos únicos dois conectores de um poema predominantemente assindético faz com que fique ainda mais evidente uma conexão que não segue a lógica do nosso conhecimento de mundo e que cria uma interdependência apenas aparente entre os versos, reforçando a idéia de que não há razão para que aconteçam as performances. 
Vejamos o que provoca a presença do conector allora (então). Paralelo a alors do francês, estudado por Maingueneau (1997: 175-179) junto com donc e ainsi (em italiano respectivamente dunque e cosi), o conector argumentativo allora liga a segunda inserção discurso direto à performance narrada logo em seguida. Ele aparece no mesmo verso em que termina a resposta e são fechadas as aspas (verso 9), iniciando uma oração que continua no verso seguinte (verso 10). Cria-se assim um enjambement que permite uma momentânea separação entre o conector conclusivo que introduz uma conseqüência e a conseqüência em si:

\begin{tabular}{|l|l|}
\hline $\begin{array}{l}\text { (P) } \text { È andata } \\
\text { via. (Q) } \text { Allora }\end{array}$ & $\begin{array}{l}\text { (P) Foi } \\
\text { embora. (Q) Então } \\
\text { l'ho sposata ancora. }\end{array}$ \\
& casei com ela de novo. \\
\hline
\end{tabular}

Afirma Maingueneau que, quando são usados conectores conclusivos, se pressupõe uma relação necessária entre $(\mathrm{P})$ e $(\mathrm{Q})$, sendo que $(\mathrm{P})$ é apresentado como fato definitivo. A diferença entre donc e alors é que, no primeiro caso, (Q) “aparece legitimado por princípios geralmente admitidos, não por motivos pessoais", enquanto

geralmente, "P alors Q" aparece como um processo de dedução dotado de tonalidade mais subjetiva, menos ligada à existência de uma norma reconhecida. [...] Enquanto donc liga de maneira necessária, alors contenta-se em validar a transição de um a outro, de colocar Q como a finalidade do dizer. (1997: 176) ${ }^{48}$

\footnotetext{
${ }^{48}$ Nessa afirmação de Maingueneau reconhece-se a influência dos estudos realizados por Anna Zenone e publicados nos Cahiers de Linguistique Française $\mathrm{n}^{\circ} 4$ e 5 que contêm um ensaio, dividido em duas partes, dedicado aos conectores argumentativos donc, par consequent, alors, ainsi, aussi. Concentrando-se nos conectores donc e alors, Zenone contrapõe, por um lado, as orações (1) Socrate est un homme, donc il est mortel e ( $\left.1^{1}\right)$ Socrate est un homme, alors il est mortel; e, por outro, (2) Il pleut, donc je ne vais pas me promener e (2 ${ }^{1}$ ) Il pleut, alors je ne vais pas me promener, e conclui que (1) e $\left(2^{1}\right)$ "semblent bien plus naturels." ["parecem bem mais naturais."] Continua a estudiosa afirmando, depois, que "en effet alors je ne vais pas me promener apparaît comme une décision personnelle, subjective, que l'énonciateur a prise à cause de la pluie. En revanche il est plus difficile de faire le même raisonnement avec $\left(1^{1}\right)$, aussi figée que soit l'expression, car la relation entre 'humanité' et 'mortalité' $n$ 'est pas propre à sa conception du monde." ["de fato, alors je ne vais pas me promener aparece como uma decisão
} 
O enunciador serve-se, então, do conector para criar uma justificação "subjetiva" para a enunciação de (Q), que aparece legitimada pela premissa (P), mesmo não sendo ela um efetivo pressuposto para a sua realização.

Uma estrutura semelhante repete-se após a terceira interrogação. Como dissemos, à pergunta "Come va?" responde-se "Va". No mesmo verso aparece o conector argumentativo "ma" que introduz um argumento em direção contrária. Aqui também o “ma”, colocado no fim do verso e separado da conclusão que introduz, cria um efeito de suspense, já que insere uma pausa antes de chegar ao momento em que se revela a conclusão argumentativa a que ele vai levar. Como no caso de allora, observa-se assim um enjambement:

\begin{tabular}{|l|l|}
\hline & \\
Come va? & Como vai? \\
(P) Va. $(\boldsymbol{Q})$ Ma & (P) Vai. $(\mathbf{Q})$ Mas \\
ho lasciato anche lei. & deixei ela também. \\
\hline
\end{tabular}

Retomemos Maingueneau e suas reflexões sobre os diferentes tipos de "mas". Afirma ele que quando está presente um conector desse tipo "assiste-se [...] ao confronto entre dois pontos de vista sucessivos que argumentam em direções opostas." (1996: 68) Se lembrarmos então que, pela posição ocupada, a interrogação pode ser interpretada como relacionada a um casamento, o que se esperaria, após uma resposta neutra e sem nenhuma avaliação negativa, seria a decisão de o sujeito permanecer conjunto com o objeto-valor: a premissa $(\mathrm{P})$ deveria levar a uma

pessoal, subjetiva, que o enunciador tomou por causa da chuva. Ao contrário, é mais difícil fazer o mesmo raciocínio com $\left(1^{1}\right)$, por ser tão fixa a expressão, porque a relação entre 'humanidade' e 'mortalidade' não é própria da sua concepção de mundo.”] (1982: 117). 
conseqüência (r). Acontece, contudo, que a escolha argumentativa do " $m a$ " nos faz entender que o eu diz concordar com a premissa contida na debreagem, mas afirma, ao mesmo tempo, que quer distanciar-se dela para sugerir uma outra conseqüência inesperada e "injustificada" (Q), que é no nosso caso a decisão de deixar o objeto-valor.

O uso do " $m a$ ” leva, portanto, a pensar com Ducrot que:

[...] de fato, a única coisa constante é que o locutor declara negligenciar o primeiro [enunciado] da argumentação que está construindo, para apoiar-se apenas no segundo - a força argumentativa superior atribuída a este não passa de uma justificação desta decisão. ${ }^{49}$

De novo, a performance acontece "sem razões" e a partir da neutralidade.

O poema continua reforçando a idéia de separação e distanciamento e termina com o verso parto alle sei, isto é, com a decisão de "ir embora".

É interessante a introdução do presente do indicativo, tempo enunciativo que cria a ilusão da concomitância entre o momento em que o enunciador enuncia e o momento em que o enunciatário lê o poema, atualizando a cada leitura a partida e o parto, embora se deva considerar que aqui, na verdade, o presente possui valor de futuro porque prefigura uma ação que está por vir, pois é indicado o tempo crônico, o horário em que a performance se realizará (às seis horas). Cria-se assim o simulacro de uma ancoragem temporal que se renova a cada leitura e que provoca

\footnotetext{
49 “[...] en fait la seule chose constante, c'est que le locuteur déclare négliger le premier [enoncé] dans l'argumentation qu'il est en train de construire, et s'appuyer seulement sur le second - la force argumentative supérieure accordée à celui-ci n'etant qu'une justification de cette décision." (DUCROT, 1983: 9).
} 
no co-enunciador a ilusão de transferir sempre para o futuro a realização da performance anunciada.

Observa-se uma dupla tematização da figuratividade que, fundada por uma série de identidades semânticas parciais, estabelece duas isotopias paralelas: a da partida desdobra-se nos predicados sono partito, sono andato, è andata via, enquanto a do parto permanece limitada ao primeiro e ao último verso. Poderia-se, portanto, dizer que a isotopia do partir rege a do parto, evidenciando o traço da separação e do afastamento.

Esse último verso pode ser interpretado como conseqüência dessa separação ou como início de um novo ciclo. De fato, o lexema parto em que se apóia o verso é legível em dois níveis semêmicos diferentes: por um lado, é o substantivo parto que vem de partorire e, por outro, é parto como primeira pessoa singular do presente do indicativo do verbo partire. Poderia, portanto, estar marcada uma partida para as seis horas, mas também um parto, um nascimento que, como vimos, também é separação. 


\subsubsection{SE ORA TUBUSSASS ALLAMIA PORTA-Patrizia Cavalli}

Se ora tu bussassi alla mia porta e ti togliessi gli occhiali

e io togliessi i miei che sono uguali

e poi tu entrassi dentro la mia bocca senza temere baci disuguali

e mi dicessi: "Amore mio,

ma che è successo?», sarebbe un pezzo

di teatro di successo.

Se agora você batesse à minha porta e tirasse os seus óculos

e eu tirasse os meus que são iguais

e depois você entrasse dentro da minha boca

sem medo de beijos desiguais

e me dissesse: "Meu amor,

mas o que se passou?", seria uma peça

de teatro de sucesso.

(Patrizia Cavalli, Poesie (1974-1992), 1992) 
Ungaretti costumava dizer que o hendecassílabo é o metro da língua poética italiana e afirmou num artigo intitulado "Defesa do hendecassílabo" que "todo verdadeiro poeta italiano o tem no sangue" porque "é a ordem poética natural das palavras italianas" (1994: 56), que oferece enormes potencialidades expressivas e permite articulações surpreendentes.

É justamente esse o metro (do grego métron, medida) que predomina no poema de Patrizia Cavalli: embora haja, também, variações métricas que aumentam ainda mais suas possibilidades musicais, são os hendecassílabos que guiam a composição. Constituído por uma só estrofe e por apenas oito versos, o poema transmite, entretanto, a impressão de que a versificação é quase "espontânea" reproduzindo o fluxo da oralidade sem a necessidade (aparente) de um trabalho minucioso com o número de sílabas e com o acento tônico marcado que com sua função "de agente melódico e de agente rítmico" (UnGARETTI, 1994: 71) é o alicerce da poesia italiana contemporânea.

A rima (occhiali/uguali/disuguali), a assonância (porta/bocca) e as aliterações são outros elementos essenciais no jogo com as sonoridades que fundamenta o poema, conferindo-lhe unidade e regularidade fônica. É interessante nesse sentido a alternância entre as vogais abertas /a/ e /o/ e as vogais fechadas /i/ e /u/, que evoca a oposição entre abrir e fechar reconhecível no texto. Desempenha um papel central, também, a evidente aliteração dada pela repetição da constritiva alveolar /s/, quase sempre em sílaba tônica, que estabelece uma "isotopia sonora"50

\footnotetext{
${ }^{50}$ A expressão "isotopia sonora", que tomamos de Greimas, refere-se à possibilidade de transferir o conceito de isotopia do plano do conteúdo para o plano da expressão. "Parece ser possível postular um nível fonêmico que dê margem a uma leitura isotópica" afirma Greimas e acrescenta: "Desenrolando-se sobre o plano da expressão, o discurso poético poderia assim ser concebido sob forma de uma projeção de feixes fêmicos isotópicos, onde seriam reconhecidas as simetrias e as alternâncias, as consonâncias e as dissonâncias e, finalmente, as transformações significativas dos conjuntos sonoros." (1975b: 22).
} 
aparecendo, com uma única exceção, em todos os versos e produzindo o efeito de acentuar o caráter intimista do texto e de lembrar uma fala em voz baixa, como um sussurro.

Cinco vezes o som /s/ está em início de palavra - se, senza, successo (duas vezes) e sarebbe -, enquanto nas outras ocorrências é em posição intervocálica e graficamente representado pela dupla consoante "ss". Isso acontece oito vezes, cinco das quais são reiterações do pretérito imperfeito do subjuntivo. Trata-se dos predicados das cinco orações subordinadas regidas pelo conectivo condicional "se" que inicia o texto introduzindo o longo período hipotético com que é formado o poema.

Antes de deter-nos nas implicações que esse tipo de construção traz consigo, cabe dirigir brevemente a atenção ao "Se", que por ser a primeira palavra do poema, é escrito com letra maiúscula. Trata-se da única maiúscula em posição inicial (aliás, da única maiúscula de todo o poema, excetuando a palavra "Amore" que abre a debreagem de que falaremos a seguir) e isso tem por conseqüência que o conectivo não somente determina a estrutura morfológica e sintática do texto, mas também domina e "sustenta" graficamente o "espaço físico" ocupado pelo poema, que ele rege sem interrupções até a inserção do discurso direto. Somente após a vírgula, que marca o fim da debreagem enunciativa de segundo grau, começa a oração principal, que completa o período hipotético - ao qual ainda faltava uma conclusão - e todo o poema.

O período hipotético, também chamado condicional, é composto por uma ou mais prótases (são cinco no caso do poema que analisamos aqui) que indicam a condição da qual depende ou poderia depender aquilo que se afirma na apódose, que é a oração principal. Existem diferentes classificações de período hipotético, mas em italiano ele é tradicionalmente chamado real (ou 
della realtà) quando é construído com as diferentes formas verbais do indicativo; possível (ou della possibilità) quando se caracteriza por ter na prótase um pretérito imperfeito do subjuntivo (em italiano chamado congiuntivo imperfetto) e na apódose um futuro do pretérito (em italiano, condizionale presente); e irreal (ou dell'irrealtà) quando os modos são os mesmos do tipo anterior, mas há também a construção com o pretérito mais-que-perfeito do subjuntivo (congiuntivo trapassato) e o futuro do pretérito composto (condizionale passato) com resultados que pressupõem algo que já aconteceu e, por isso, não pode mais realizar-se ${ }^{51}$. Completam a classificação os períodos hipotéticos mistos que são constituídos por contaminações entre modos reais e modos possíveis ou irreais (DARDANO/TRIFONE, 1997: 413).

Até aqui a descrição gramatical. Ora, a questão interessante é que, segundo Serianni,

contudo, uma partição desse tipo é insatisfatória. Tanto porque contamina critérios tipológicos diferentes (um formal: o modo verbal usado; e um lógico: o caráter real, possível ou irreal na hipótese), quanto - e principalmente - por causa da impossibilidade de se traçarem barreiras nítidas. Dizendo: "Se eu fosse rico, viajaria muito", formulo uma hipótese possível ou irreal $?^{52}$

A diferença entre possibilidade e irrealidade dar-se-ia, portanto, pela lógica, ou seja, as frases logicamente realizáveis seriam colocadas no campo da possibilidade e as irrealizáveis como, por exemplo, "Se avessi le ali, volerei da te” ("Se tivesse asas, voaria até você”) no campo da irrealidade. Por mais que, como vimos, essa distinção seja, segundo admite o próprio Serianni, difícil de considerar confiável pela dificuldade de distinguir entre o possível e o irreal, o

\footnotetext{
${ }^{51}$ Estamos falando de casos em que, como no exemplo Se fossi venuta, sarei stata felice, é claro que a ação indicada na prótase pertence ao passado e, portanto, não existe mais possibilidade alguma de que se concretize.

52 "Tuttavia, una partizione del genere è insoddisfacente. Sia perché contamina criteri tipologici diversi (uno formale: il modo verbale usato; e uno logico: il carattere reale, possibile o irreale dell'ipotesi), sia - e soprattutto per l'impossibilità di tracciare confini netti. Dicendo «Se fossi ricco, viaggerei molto», formulo un'ipotesi possibile o irreale?" (1997: 411).
} 
que temos no caso do poema em pauta é justamente essa situação, que nos faz oscilar ao longo da leitura entre o considerar possível e realizável ou, então, impossível e irrealizável a situação figurativa que nos é apresentada.

Para as finalidades da análise e da compreensão do poema o que importa é que, pela escolha do tempo verbal e, portanto, do tipo de período hipotético, a ação nele descrita é colocada numa espécie de entre-lugar, no qual a possibilidade e a irrealidade se cruzam: o enunciador joga justamente com a impossibilidade de uma nítida definição e separação e prepara para a apódose que conclui a manifestação de um plano imaginário no qual transitam valores provavelmente considerados inalcançáveis. Podemos então depreender, especialmente pelo final do poema, que a hipótese imaginada se apóia em antecedentes pouco favoráveis que fazem o eu concluir que aquilo que está "visualizando" provavelmente não se concretizará, mas sem que se elimine, contudo, a "esperança" de uma realização.

De qualquer forma, contrapõem-se aqui uma ausência (realizada) e uma presença (imaginada) que interpretamos como desejo, considerando que o período hipotético pode estar imbuído da modalidade do querer, com o qual se propõe um programa narrativo que permanece em estado virtual exatamente por ser dotado apenas de um querer por parte do enunciador.

Mas voltemos agora ao primeiro verso: percebemos que nele já são instalados indícios de temporalização, actorialização e espacialização.

Logo depois do conectivo "se", aparece, de fato, um advérbio de tempo "ora" ("agora") como instância enunciativa a partir da qual se introduz a situação hipotética, de forma que o “ora”, lido junto com o "poi” (“depois") colocado alguns versos adiante, reforça a idéia de uma 
hipótese projetada num futuro indefinido do qual nada se sabe e que indica um tempo suspenso explicitado por meio do congiuntivo imperfetto desde a primeira prótase do período hipotético.

A enunciatividade do texto é confirmada pelo aparecimento de um $t u$, logo em seguida, que instala automaticamente um $e u$, pois só o $e u$ pode dizer $t u$. É esse $e u$ que atravessa como sujeito do enunciado todo o poema, mostrando-se e mostrando o $t u$ por meio de pronomes pessoais e possessivos da primeira e da segunda pessoa do singular que, por aparecer sempre lado a lado, figurativizam um entrelaçamento entre o $e u$ e o $t u$.

É interessante notar a recorrência das escolhas nesse sentido: enquanto os possessivos são todos de primeira pessoa (mia, miei, mia, mio), o sujeito das ações "imaginadas" é, com uma única exceção, o tu ao qual é atribuído pelo enunciador o papel de actante-sujeito: é o tu que bate à porta, tira os óculos, entra na boca e fala com o eu.

Manifesta-se, então, a oposição semântica fundamental /identidade/ vs /alteridade/, mas, contrariamente ao que acontecia no primeiro poema analisado, não temos aqui indicação alguma de gênero: nem a gramática, nem a semântica são apresentadas de uma maneira que faça necessária uma especificação. Todavia pode ser interessante pensar que na comparação e no “encontro imaginário" entre os dois sujeitos são utilizadas as categorias igualdade (os óculos são iguais) e desigualdade (beijos desiguais) que são a única definição da "relação" entre o ator que enuncia e o ser amado imaginado, que ocupa o lugar da segunda pessoa.

Não há dimensão pragmática: tudo se realiza no espaço imaginário do enunciador que cria para o co-enunciador a ilusão de coincidir com o eu que aparece no texto. $\mathrm{O} e u$ é um sujeito 
passional que não age, mas gostaria de "ser agido", ou seja, gostaria de ser desejado e se configura no nível narrativo como sujeito em espera e no nível modal como sujeito do desejo. Trata-se também de um sujeito em falta que quer a conjunção com o objeto-valor "pessoa amada" e busca na imaginação essa conjunção com o outro, cuja ausência parece desta forma temporariamente compensada, por mais que a situação seja concebida exclusivamente na instância do eu. Aos aspectos eufóricos trazidos pela imaginação contrapõe-se, portanto, a disforia, a descontinuidade de quem já sabe que aquilo que imagina provavelmente não poderá realizar-se. A axiologia subjacente reconduz à idéia do sonho do amor romântico, no qual o objeto desejável é o outro, o tu que representa o amor de outros tempos, isto é, um amor sem limites em que um se lança ao outro sem medo do julgamento exterior.

Pelo que concerne às figuras relacionadas ao espaço, temos no primeiro verso a menção de um "lugar": "alla mia porta" ("à minha porta") que, pondo metonimicamente em cena a casa, chama para o texto a idéia de espaço doméstico, além de indicar não só a contraposição espacial entre o aberto e o fechado, já citada anteriormente, mas também uma direcionalidade de fora para dentro, que inicia no primeiro verso e percorre todo o poema.

Continua essa isotopia a figura da boca ("e poi tu entrassi dentro la mia bocca"). Se "minha porta" remete à casa como metáfora do espaço privado, "minha boca" convoca a idéia do corpo como espaço ainda mais íntimo, ainda mais privado. A respeito de sua figurativização, cabe lembrar que a "boca" é a única parte explicitamente citada, mesmo estando o corpo muito presente no texto: podemos "ver" mãos que batem à porta e que tiram os óculos; olhos atrás desses óculos; e uma boca em que se entra, mas também que beija e que fala. Pode-se observar uma referência aos sentidos, à percepção sensorial do mundo por parte do sujeito e, direta ou 
indiretamente, os sentidos entram no texto: o tato pelas mãos; a visão pelos olhos; o paladar pela boca; e a audição, se imaginarmos ouvidos que escutam a voz que fala. A corporalidade e a sensorialidade que estão no enunciado enunciado constroem o espaço discursivo do encontro entre o eu e o tu: é, pois, através do corpo que se estabelece o contato entre os dois sujeitos como mostram as ações "imaginadas" indicando, na maioria dos casos, um movimento do tu em direção ao $e u$ e, portanto, a aproximação desejada.

Voltando agora à "porta" e à "boca" como lugares de transição entre o fora e o dentro e como representação da barreira que separa a exterioridade e a interioridade, que aqui se opõem, vale a pena acrescentar mais algumas observações. No primeiro caso, o sujeito imagina o outro à sua porta, pedindo licença para poder entrar: a penetração do espaço doméstico é controlada pelo $e u$ e a porta à qual se bate pode abrir-se ou pode permanecer fechada. No caso da boca, repete-se a imagem do "lugar" que se abre e se fecha, mas o entrar é explicitado ("e poi tu entrassi" diz o poema), além de ser também enfatizado pelo uso preposicional de "dentro" e pela reiteração do possessivo de primeira pessoa "mia", por meio do qual se sublinha a idéia do espaço íntimo do eu.

Há, entre as duas figuras citadas, dois versos construídos a partir de uma outra imagem, a dos óculos, representando mais uma vez uma ligação entre a exterioridade e a interioridade. A direção é desta vez de dentro para fora, já que os óculos são o instrumento por meio do qual um sujeito enxerga a partir de dentro o mundo fora dele.

O elemento essencial aqui é que tanto o $t u$ (no verso 2) quanto o $e u$ (no verso 3) são imaginados na performance de tirar óculos (iguais) e de livrar-se, portanto, do "filtro" através do qual vêem o mundo externo, das lentes por meio das quais se deveria enxergá-lo "melhor". 
A imagem do "tirar os óculos" pode, entretanto, ser lida também como "tirar a máscara" com a qual o eu e o tu olham de dentro para fora, mas pela qual, ao mesmo tempo, são vistos por fora. Essa interpretação dos óculos como máscara desencadeia a leitura isotópica da teatralidade relacionada tanto à exterioridade de que já falamos, quanto ao teatro em si que será citado explicitamente só no final do poema.

A seqüência de figuras e de performances imaginadas (bussare alla porta, entrare dentro la bocca, togliere gli occhiali, etc.) faz com que possa ser identificada uma narrativa que se concretiza justamente na passagem de uma figura a outra. Embora tudo aconteça evidentemente no campo da imaginação, depreende-se uma impressão de realidade, cuja coerência discursiva é dada por uma isotopia comum que tece uma ligação entre cada uma das figuras.

Uma performance sucede a outra e elas formam um conjunto também porque estão todas ligadas pela repetição do conector aditivo "e" no início de quatro dos sete versos. O poema é, portanto, um polissíndeto que une sintaticamente as orações subordinadas iniciadas por " $e$ " mostrando, assim, que são coordenadas entre si, que criam um paralelismo e que têm uma função de prótase idêntica à da primeira oração introduzida pelo conectivo condicional "se" que constitui a condição da conseqüência enunciada após a última vírgula ("sarebbe un pezzo di teatro di successo").

O polissíndeto contribui para a criação da cadência, marcando pausas no ritmo e criando um efeito de lentidão, já que separa as ações prefiguradas e as imagens que elas constroem uma se encaixando na outra e uma pressupondo a outra para poder acontecer. Nesse contexto, o uso do advérbio de tempo "poi" sublinha a seqüencialidade e reforça o efeito de sucessão de 
acontecimentos criado pelo polissíndeto junto com a idéia da necessidade de que a performance anterior seja feita para que a subseqüente possa ser feita também.

Merece atenção o verso 5, o único que não baseia na sonoridade sua força e sua “integração" na composição poética, já que contém só no início do verso o som /s/ ("senza”), mas não a citada consoante dobrada. "Senza temere baci disuguali" diz o verso, "sem temer beijos desiguais" dissemos na tradução. O infinitivo "temere" é introduzido pelo conectivo "senza" que contém, por sua própria natureza negativo-modal, uma dupla função: por um lado, expressa o desejo do $e u$ de que o $t u$ não tenha medo e, por outro, deixa transparecer a constatação de que esse medo existe. Se não fosse assim, não seria necessário incluir essa oração na situação imaginada. O medo é definido pela presença do "não querer estar em conjunção com algo disfórico", representado aqui pelos "beijos desiguais". A imagem pressupõe um contato íntimo entre os dois sujeitos e a possibilidade de que haja uma disparidade entre seus sentimentos figurativizados pelos beijos. É essa a situação disfórica que pode produzir aquela "intensa perturbação misturada com preocupação e inquietude" que o dicionário chama "medo".

Após essa afirmação, o eu imagina uma fala, palavras que delimitam a presença do outro, mostrando e marcando a heterogeneidade e fazendo "audível" a voz do $t u$. A debreagem enunciativa de segundo grau pertence ainda à prótase do período hipotético e é, portanto, apenas "representação" que entra no esquema criado pelo texto. O tu "imaginário", que desde o primeiro verso atravessa o poema, ganha voz e concretude por meio do discurso direto, que, embora imaginário, cria a ilusão de estarmos ouvindo uma voz, de estarmos lendo palavras que foram pronunciadas por alguém exatamente como as estamos lendo. 
Além disso, a escolha de utilizar o discurso direto pode ser lida como tendo também a função de imitar a fala teatral, o papel da "personagem" e assim ser considerada parte da isotopia da teatralidade e da exterioridade que, como dissemos, se completa e se torna evidente no último verso, quando é diretamente mencionado o teatro, o palco que é exterioridade, mas que constrói o efeito de sentido de verdade, já que na ficção do teatro há personagens e falas que agem "como se fosse na vida real".

A debreagem começa com um vocativo: "Amore mio" diz o tu e isso elimina qualquer dúvida quanto ao tipo de relação existente entre os dois sujeitos, confirmando que se trata de uma relação amorosa.

Prossegue-se com um “ma”, que nesse caso não possui a clássica função de conector argumentativo, mas contrapõe-se a tudo o que foi colocado antes da inserção da voz do $t u$, ligando duas "entidades" heterogêneas. O papel do " $m a$ " pode, então, ser aqui o de mostrar a reação do sujeito em relação a algo inesperado, que o faz iniciar sua fala como se fosse um comentário sobre o que acabou de ser descrito ${ }^{53}$.

A continuação "ma che è successo?" ("mas o que aconteceu?”) confirma essa interpretação e também implica a percepção do outro, o interesse em relação ao outro, já que faz pensar numa contraposição entre amor e indiferença, usual e insólito, esperado e surpreendente.

Vimos que o discurso direto se encerra com o lexema "successo", que tem aqui a função de particípio passado do verbo succedere (acontecer). Um lexema homófono e homógrafo aparece

\footnotetext{
${ }^{53}$ Para outras considerações sobre esse tipo de "mas” não argumentativo, ver também MAINGUENEAU, 1996a: 63-71.
} 
no verso seguinte e fecha o poema. Na segunda ocorrência seu valor semêmico é, porém, outro: "successo" é desta vez substantivo e é usado em conjunto com a preposição "di" adquirindo o valor de locução adjetival que define a peça de teatro a que se compara toda a situação descrita e indica que ela conquistaria o consenso e a aprovação do público, que ganharia popularidade.

Realiza-se, portanto, uma antanáclase, dada pela repetição de dois lexemas idênticos na aparência, mas utilizados em acepções diferentes. Aqui, ademais, os lexemas possuem distinta função gramatical, acentuando ainda mais o contraste entre a "aparência" e o "conteúdo". Obtémse assim um efeito de surpresa ressaltado pelo contraste entre aquilo que se esperaria a partir da seqüência de performances imaginadas e o inesperado que toma seu lugar e provoca ironia.

Acontece, além disso, que tanto a prótase quanto a apódose terminam com a palavra successo o que enfatiza a bipartição do texto, já que o lexema fecha as duas unidades lógicas. Na ocorrência do verso 7 successo - colocado no final da pergunta - conclui não só a série de prótases iniciada no primeiro verso, mas também o discurso direto que é, portanto, duplamente "fechado" pelas aspas angulares e pela vírgula que indica o fim de uma parte e o começo da outra.

Essa posição de relevo que o lexema ocupa influi também na sonoridade do poema, pois pode considerar-se que, apesar das diferentes posições ocupadas, forma um conjunto equiparável a uma rima, embora, pela primeira vez, não apareça no fim do verso.

Isso cria um efeito interessante também do ponto de vista da sonoridade do texto, já que se insere na "isotopia sonora" da consoante /s/ que mencionamos no início, reforçando o efeito de unidade. 
Chegamos ao final do poema. A apódose que o termina se apresenta como sanção cognitiva do eu que adquire o papel de destinador-julgador de todas as performances narradas e diz: "sarebbe un pezzo di teatro di successo" mencionando o teatro e, em particular, uma peça de sucesso.

Desaparecem nessa parte do poema todas as marcas actanciais enunciativas e sobra uma terceira pessoa, cujo sujeito gramatical é a peça de teatro, que confere à apódose um efeito de sentido de objetividade, além de dar mais força à conclusão que parece dizer que o amor romântico da tradição não existe mais e pode, portanto, apenas ser sonhado e imaginado com a consciência de que não se realizará, ou de que sua realização é tão improvável quanto uma peça de teatro de sucesso, onde acontece aquilo de que a massa gosta, mas apenas como representação, geralmente diferente da vida "real". O período hipotético é imaginado e não "real" assim como o teatro e a representação teatral que também são somente "imitação" da realidade. 


\subsubsection{LA POESIA OGGI-Sebastiano Vassalli}

Ci sono persone ovunque, anche in questo paese,

Che siedono attorno a "tavole rotonde",

Che prendono e danno premi, che scrivono

"La poesia oggi" oppure "la funzione del poeta".

Della funzione del poeta non saprei dire nulla;

La poesia oggi - questa sì, io la posso indicare,

Sta nei grandi magazzini, nei settimanali illustrati,

Nella pubblicità al cinema, nelle facce della gente

Che vede le famose cortigiane, gli animali lussuosi e splendidi,

Che instillarono nel cuore del "poeta" l'Ideale lontano,

per cui in milioni morirono o delirando vissero,

Passare dalla saponetta al vinello toscano

All'abito già pronto, imprimersi in suggello

D'un amore lontano su birra o su profumo

Risciacquar pavimenti o sturare un lavabo

- La gente guarda e tace, entra al supermercato.

Há pessoas em todo lugar, também nesse país,

Que sentam em volta de "mesas redondas",

Que recebem e dão prêmios, que escrevem

"A poesia hoje" ou "a função do poeta"

Sobre a função do poeta não saberia dizer nada;

A poesia hoje - essa sim, eu posso indicá-la,

Está nas lojas de departamento, nas revistas ${ }^{34}$ ilustradas,

Na publicidade no cinema, nos rostos da gente

Que vê as famosas cortesãs, os animais luxuosos e esplêndidos,

Que instilaram no coração do "poeta" o Ideal distante,

Pelo qual milhões morreram ou delirando viveram,

Passar do sabonete ao vinhozinho toscano

Ao vestido já pronto, imprimir-se em sigilo

De um amor distante sobre cerveja ou perfume

Enxaguar pisos ou desentupir uma pia

- A gente olha e cala, entra no supermercado.

(Sebastiano Vassalli, Ant.Ed., 1971)

\footnotetext{
${ }^{54}$ Os "settimanali" são, na verdade, hebdomadários. Optamos por traduzir simplesmente por "revistas" por achar mais importante manter a cotidianidade e o registro não marcado.
} 
La poesia oggi é um poema que aparentemente não se deixa atrair pelo fascínio da métrica regular, da rima evidente, das assonâncias e das aliterações facilmente reconhecíveis. Existe, contudo, um cuidado com a sonoridade, que contribui para o efeito rítmico do texto, mas precisa ser descoberto a cada leitura nos acentos tônicos e na observação das recorrências presentes mesmo na irregularidade.

O poema está dividido em quatro estrofes de quatro versos cada uma, que criam segmentações, intervalos e pausas internas. Pode parecer que essa divisão não corresponda a uma partição interna "necessária", mas derive de uma decisão "arbitrária". De fato, só a primeira estrofe termina com um ponto e fecha uma unidade, enquanto as outras três são ligadas entre si por enjambement e formam sintaticamente um conjunto, no interior do qual apenas o último verso pode considerar-se separado do resto.

Há, entretanto, várias outras segmentações possíveis: seguindo aquela que nos parece mais produtiva para a leitura e a análise do texto, poderíamos dividi-lo em três partes, cada uma representando um "universo" diferente. Uma primeira parte, que podemos considerar constituída pelos seis versos iniciais, descreve o universo dos poetas e dos críticos literários. Uma segunda que faremos iniciar no sétimo verso - refere-se ao mundo do consumo, enquanto a terceira se encaixa dentro dela, ocupando em particular do verso 9 ao verso 11 , e tem como universo de referência o da "poesia do passado".

O título do poema indica desde o início que a poesia é o tema central ao redor do qual o texto se constrói. É a poesia que fala de si mesma e se torna então "metapoesia". Prova disso é 
também que os lexemas "poesia" e "poeta", repetidos três vezes cada um (considerando tanto o título, quanto o corpo do texto), ocupam posições estratégicas, veiculam sentidos e estabelecem conexões.

Pertence ainda ao título o advérbio de tempo enunciativo "oggi" ("hoje"), que delimita o tema e introduz a idéia da contemporaneidade da poesia com um "agora", atualizado a cada leitura e preenchido sempre de novos significados.

Vejamos como o poema continua. Na primeira estrofe há uma debreagem actancial enunciva: fala-se de uma terceira pessoa do plural, identificada num genérico "persone" ("pessoas"), que constitui um grupo do qual o eu se exclui. Como dissemos, o grupo que se apresenta é o dos poetas e dos críticos literários. São enumeradas performances que o caracterizam: os debates (siedono intorno a "tavole rotonde"), as entregas de prêmios (prendono e danno premi), os ensaios sobre a função do poeta e sobre a poesia (scrivono "La poesia oggi" oppure "la funzione del poeta"). Não há aparentemente julgamentos por parte do enunciador, mas se observarmos a maneira como as ações são apresentadas, percebemos que se manifesta nela mais do que uma simples descrição. Acontece, de fato, que em todas as performances as mesmas "pessoas" desempenham tanto o papel de actante-destinador, quanto o papel de destinatário: poetas e críticos literários são as "mesmas pessoas" e debatem entre si, decidem entre si quem dá e quem recebe prêmios, escrevem sobre eles mesmos. O resultado é que se põe em cena um universo fechado, sem abertura e sem diálogo com o mundo externo, que vive alimentando-se de si mesmo, numa sorte de "auto-referencialidade" vazia, à qual o enunciador, como se verá também depois, atribui uma avaliação disforíca. 
Em consonância com o advérbio enunciativo oggi presente no título, o tempo verbal utilizado nessa primeira parte do poema é um presente do indicativo durativo e iterativo: durativo, porque o momento de referência é certamente mais longo do que o momento da enunciação; e iterativo, pois o momento de referência e o momento do acontecimento não são explicitados, mas a partir do agora do momento da enunciação as performances citadas são apresentadas como reiteradas e habituais ${ }^{55}$.

O presente do indicativo também possui o poder de atualizar o que é dito e de criar a ilusão de o momento da enunciação e o momento da "recepção" do poema serem idênticos, de modo que o enunciatário remete o que lê ao seu "agora", criando-se assim um efeito de sentido de aproximação. Como afirma Fiorin:

[...] a temporalidade do enunciador é aceita como sua pelo enunciatário. O agora do enunciador é o agora do enunciatário. [...] O tempo do discurso não é, assim, reportado às divisões do tempo crônico nem fechado numa subjetividade solipsista. A interação lingüística, que pressupõe uma troca intersubjetiva, transforma o tempo lingüístico de unipessoal em omnipessoal (1996a: 143).

Completa a enunciatividade o pronome demonstrativo espacial "questo" de "in questo paese" ("nesse país"), por meio do qual se cria o efeito de também o espaço do enunciador coincidir com o espaço do enunciatário, que o aceita como seu, independente do lugar "real" em que foi enunciado e do lugar "real" em que é lido, já que ele "é reinventado cada vez que alguém toma a palavra, porque, em cada ato enunciativo, temos um espaço novo ainda não habitado por ninguém” (FIORIN, 1996a: 263).

\footnotetext{
${ }^{55}$ Cf. FIORIN, 1996a: 149-150.
} 
Estamos ainda no primeiro verso e essa já é a segunda referência ao espaço, que mostra assim sua centralidade no poema. O sintagma citado é o elemento "do meio" na seqüência formada por ovunque, in questo paese, attorno a "tavole rotonde" (em todo lugar, nesse país, em volta de "mesas redondas") que começa mencionando um espaço praticamente sem limites e vai restringindo a parte dele a ser levada em consideração, como se o olhar começasse a ver de longe e fosse aproximando-se cada vez mais, num efeito parecido ao da focalização progressiva de um zoom. Podemos imaginar círculos concêntricos, um englobando o outro de maneira que de todo lugar se passe a esse país e do país às várias mesas redondas que nele (também) acontecem.

É usado três vezes nessa primeira estrofe o recurso gráfico das aspas (ao qual o enunciador recorrerá de novo mais adiante). Em geral, usa-se esse recurso para manter-se à distância de determinadas expressões que o eu não quer assumir como suas ou cujo significado e origem ele, por meio dessa escolha, quer evidenciar. As aspas parecem assinalar tanto uma utilização, em certa medida, imprópria de determinadas palavras, quanto também que as palavras usadas pertencem a outro discurso, que "chamado" por meio desse sinal gráfico, acaba acrescentando sentidos. De fato, elas são suficientes para mostrar que uma palavra pode ter duas (ou mais) interpretações, mas podem também manifestar dois pontos de vista e revelar duas vozes.

Nesse poema elas têm, além disso, a função de induzir a pensar na relação entre o mundo que está se descrevendo e um outro mundo ao qual se faz referência. Escrever entre aspas "tavole rotonde" ("mesas redondas"), por exemplo, pode ser interpretado tanto como uma depreciação dessas "mesas redondas" e do que nelas é discutido, quanto como uma referência às mesas redondas das sagas do rei Artur, onde se procurava o que não era possível encontrar. A convocação do universo mítico do rei Artur e de sua "Távola redonda" é evidentemente paródica 
e é provavelmente uma maneira para falar por contraste da pouca importância dos debates em torno do tema da poesia e da função do poeta. De fato, são de novo usadas as aspas tanto para "La poesia oggi", quanto para "la funzione del poeta" (escrito assim, com letra minúscula). Pode-se pensar que o uso desse recurso gráfico tenha aqui "apenas" o objetivo de assinalar que se trata de títulos, mas há provavelmente também a intenção de mostrar um afastamento do enunciador, que quer mostrar e marcar a heterogeneidade e dar mais indícios de que considera esses "temas" pouco relevantes.

O jogo entre maiúscula e minúscula é uma primeira possível demonstração dessa suposição, já que títulos deveriam iniciar com uma letra maiúscula, que aparece aqui só no primeiro caso, que coincide também com o começo do verso (e todos os versos desse poema são escritos com letra maiúscula). Mas é nos versos a seguir que encontramos uma ainda mais confiável confirmação dessa interpretação.

Antes de mais nada, na segunda estrofe o eu se mostra. São os únicos dois versos em primeira pessoa de todo o poema, que recuperam o plano da enunciação integrando-se ao tempo do agora e ao espaço do aqui, que já apareceram na estrofe inicial preparando a debreagem actancial enunciativa.

Vê-se depois que o quarto verso, dividido em duas partes, é retomado com uma inversão nos dois seguintes (o quinto cita "a função do poeta" e o sexto "a poesia hoje") e que ambos são concluídos com uma "manifestação" do eu que declara sua posição em relação aos dois "temas" citados. No primeiro caso, modalizado pelo não saber, afirma "Della funzione del poeta non saprei dire nulla" ("Da função do poeta não saberia dizer nada"). A sobremodalização dada pelo 
uso do futuro do pretérito, criando um efeito de sentido de atenuação da falta de competência do sujeito, parece ter sido escolhida para gerar um efeito de ironia e, desta forma, dizer indiretamente que o poeta não tem função nenhuma e talvez nem deva e possa ter ${ }^{56}$.

No verso seguinte, modalizado pelo poder e dotado, portanto, da competência necessária, o eu diz: "La poesia oggi - questa sì io la posso indicare” (“A poesia hoje - essa sim, eu posso indicá-la").

A poesia, citada no início do verso e retomada anaforicamente tanto por meio do demonstrativo "questa" como do pronome "la", ocupa evidentemente um lugar central. O verso conclui-se com o verbo "indicare" e aqui se revela que o poema está essencialmente baseado na categoria da espacialidade: o eu não define a poesia, indica-a; não diz o que é, mas onde ela está. Com efeito, são mencionadas a partir do verso seguinte figuras, que se sucedem como "lugares" nos quais a poesia está e vão constituindo a imagem do mundo moderno como mundo do consumo: grandi magazzini (lojas de departamento), settimanali illustrati (revistas ilustradas), pubblicità al cinema (publicidade no cinema) e facce della gente (rostos das pessoas, da gente ${ }^{57}$ ), todos precedidos pela preposição in alterada em função da contração com os respectivos artigos definidos, reforçam e confirmam seu papel referido ao espaço.

\footnotetext{
${ }^{56}$ Vários escritores - de Álvares de Azevedo ao futurista Aldo Palazzeschi - falaram da "inutilidade" do poeta e da poesia. Interessante nesse sentido é, por exemplo, a posição de Georges Bataille, que num texto de 1944 intitulado "La littérature est-elle utile?", diz que a literatura se recusa a ser útil e não o pode ser, pois é expressão da parte essencial do ser humano, que não é redutível à utilidade.

Além disso, no mundo do consumo, ao qual o poema que estamos analisando se refere, cada vez mais guiado pelo valor absoluto da mercadoria e do dinheiro, parece óbvio que a poesia se revele cada vez mais "inútil".

${ }^{57} \mathrm{Na}$ tradução preferimos usar "gente" e não "pessoas" para podermos manter a diferença entre "persone" utilizado no início e "gente" do oitavo e do último verso, além de poder preservar o uso da terceira pessoa do singular.
} 
A estrofe termina com a imagem das pessoas, da gente, sujeito coletivo participante, que, pelo pronome relativo que a ele se refere, se torna sujeito operador da oração subordinada seguinte ("gente/che vede"; "gente/que vê"), por meio da qual se realiza a união por enjambement entre os dois versos e também entre as duas estrofes.

$\mathrm{O}$ verbo vedere que introduz a isotopia do olhar (no último verso "a gente olha") rege sintaticamente todo o resto do poema, excetuando-se o último verso, e é completado pelo infinitivo passare do verso 12 ("che vede [...] passare"; que vê [...] passar) paralelo aos outros três infinitivos da quarta estrofe: imprimersi, risciacquar e sturare, todos dependentes do mesmo verbo conjugado. A construção utilizada aqui é chamada em italiano percettiva ${ }^{58}$-porque baseada num verbo de percepção como vedere, sentire, etc. - e requer obrigatoriamente uma oração infinitiva. Uma característica dessa construção é a de ser completada por um objeto direto (aqui: "le famose cortigiane”; "as famosas cortesãs"), que possui ao mesmo tempo também a função semântica de sujeito da oração infinitiva. Outra peculiaridade é a de permitir entre o verbo conjugado e o primeiro infinitivo o "encaixe" de um número indefinido de elementos.

É justamente essa a possibilidade da qual o enunciador se serve aqui, introduzindo antes do infinitivo, não só o objeto direto, mas também um aposto ("gli animali lussuosi e splendidi"; "os animais luxuosos e esplêndidos") e duas orações relativas ("che instillarono [...]"; "que instilaram [...]" e "per cui in milioni [...]”; "pelo qual milhões [...]"). Isso já provoca o efeito de complexificar a estrutura do texto, mas há ainda, na segunda oração relativa, um predicado colocado no final da oração e uma inversão entre gerúndio e verbo conjugado que, mostrando reminiscências do latim clássico, contribuem para aumentar a complexidade sintática do

\footnotetext{
${ }^{58}$ Cf. SKYTtE/SALVi/MANZINI, 1991: 509-522.
} 
enunciado, principalmente se comparada à linearidade e à simplicidade das duas primeiras estrofes.

Essa mudança é um dos sinais que mostram a guinada que se verifica nessa parte do texto, na qual o enunciador "se desloca" do universo da mercadoria, da publicidade e do consumo para o mundo do "passado". Concentra-se, de fato, em poucos versos uma bagagem figurativa que remete ao mundo poético de um passado "distante" por meio de lexemas pertencentes a um registro que se distancia da figurativização prosaica dos versos anteriores. Aparecem aqui: “cortigiane”, “lussuoso”, "splendido”, “Ideale”, "suggello”, além do adjetivo "lontano” que se repete na quarta estrofe e também forma, junto com "toscano", a única rima "clássica" de todo o poema. Esses elementos criam um conjunto de referências e constroem uma contraposição entre o outrora e o hoje, na qual se funda o seu sentido.

Marca também a distância entre os versos que se referem à poesia do passado e os que representam o mundo contemporâneo a escolha do tempo verbal. A contraposição entre o presente do indicativo da primeira, segunda e última estrofe e o passato remoto ("instillarono", "morirono", "vissero") da terceira, que concentra o maior número de referências à poesia do tempo que se foi, descreve semi-simbolicamente a distância entre o "atual" e o "antigo". Sendo, de fato, o passato remoto um tempo enuncivo que afasta do momento da enunciação, por ter como referência apenas um momento pretérito e por se separar de quem o enuncia, ele contribui para descrever a distância e para reforçar a idéia de que se está falando de uma poesia que não pertence mais ao "mundo" concomitante com o momento da enunciação, mas a um passado “lontano", separado do enunciador. 
A repetição do adjetivo "lontano" (distante, longínquo) também remete à distância no tempo e no espaço, à inalcançabilidade do "Ideal" do poeta, e também ao "amore lontano", citado explicitamente na estrofe seguinte. Típica da poesia cortês ou provençal iniciada por Jaufré Rudel, a idéia do "amore di lontano" 59 chegou pela escola siciliana e pela corte de Frederico II até os poetas do Dolce Stil Novo, em cujos poemas o tema do delírio e da morte por amor, que vimos no texto, era muito freqüente. Com a referência às "famosas cortesãs" ("le famose cortigiane”) permanece a idéia da corte, mas é inserida no poema a figura da cortesã, típica do Renascimento. Mostra-se assim que o que importa não é tanto a exata proveniência das figuras utilizadas, quanto contrapor modernidade e antiguidade para que se possam delinear as diferenças e para que apareça, por meio delas, a posição do enunciador.

O passado euforizado contrapõe-se a um presente percebido como banal e vazio: este não conhece a intensidade das paixões que levam à poesia e que para aquele eram a base da expressão poética. O Ideale, escrito com letra maiúscula para que seja afastado dessa banalidade e lido como "verdadeiro", "grande" e "elevado", era motivo suficiente para o poeta morrer ou viver delirando, isto é, tomado pelo desejo desenfreado, pela violência explosiva de sensações, pela excitação dos sentidos e da imaginação. Valoriza-se aqui o excesso, as paixões intensas, o ardor sublime da poesia clássica que se contrapõe à indiferença do sentir contemporâneo, mencionada mais claramente no final do poema.

\footnotetext{
${ }^{59} \mathrm{O}$ poema que estamos analisando foi publicado em 1971. Em 2005 Vassalli mostra que ainda não abandonou essa idéia. Publicou, de fato, o romance Amore lontano. Il romanzo della parola attraverso i secoli [Amor distante. O romance da palavra através dos séculos] que trata do amor pela poesia por meio de breves retratos biográficos de sete personagens: Homero, Qohélet (o Eclesiasta), Virgílio, Jaufré Rudel, François Villon, Giacomo Leopardi e Arthur Rimbaud.
} 
Deixamos por último uma observação essencial para entender esses três versos, nos quais importa, é verdade, a maneira como se diz, mas há espaço também para uma referência explícita ao tema em questão: o poeta. $\mathrm{O}$ enunciador menciona-o nessa estrofe pela terceira e última vez e é interessante notar que nesta ocorrência o lexema aparece entre aspas. Dissemos antes que este sinal gráfico cria efeitos de distanciamento e sublinha a intenção por parte do enunciador de utilizar a expressão colocada entre aspas numa acepção às vezes imprópria. Ora, a impressão aqui é que as aspas têm a função de mostrar a diferença entre o poeta contemporâneo citado anteriormente e o poeta que sente intensamente, delira e morre mencionado agora, como se se quisesse dizer que este é poeta num sentido diferente em relação ao que foi mencionado antes e que é o "verdadeiro" poeta.

Contribui para a representação da intensidade passional o fato de que do "poeta" se menciona o "coração", ou seja, como diz o dicionário, a "sede dos sentimentos, das emoções, do afeto, do ânimo, da coragem”. Isso fala do seu ser diferente e, portanto, capaz de expressar o "amore lontano" que pode ser a mesma poesia, misteriosa e potente, que se insinua na vida cotidiana, mas está sempre além.

Após a "incursão" no passado, há o "retorno" ao mundo contemporâneo do consumo: o elevado e áulico mundo de outrora contrasta nitidamente com a lista de "produtos de supermercado", abundante seqüência de figuras do cotidiano: "saponetta" ("sabonete"), "vinello toscano" ("vinhozinho toscano"), "abito pronto" ("vestido pronto"), "birra" ("cerveja"), "profumo" ("perfume"), "risciacquar pavimenti" ("enxaguar pisos") e "sturare un lavabo" (“desentupir uma pia”), metonímias do mundo do consumo, que convocam o universo da propaganda. 
Sobram, contudo, nessa última estrofe alguns poucos sinais do "passado" como a apócope que transforma risciacquare em risciacquar (sem a vogal final /e/): um "pequeno" detalhe que contribui de forma determinante para dar um efeito "poético" lá onde na seleção dos lexemas não há mais poesia.

Guarda-se também um lugar para mencionar mais uma vez o "amore lontano” que dessa vez é, porém, produto: as lindas cortesãs, as mulheres bonitas, que no passado provocaram amor e instilaram ideais nos corações dos poetas são agora imagens das etiquetas da publicidade, símbolos da "mercantilização" do ser, em frente às quais as pessoas passam com indiferença.

"- La gente guarda e tace, entra al supermercato" ("- A gente olha, se cala, entra no supermercado") diz de fato o último verso que o travessão separa do resto do poema.

Observando-o com atenção, percebe-se que, apesar da presença do sinal gráfico que poderia indicá-lo, não podemos afirmar com toda certeza que se trata de discurso direto. O travessão, colocado no início do verso, poderia simplesmente sinalizar uma mudança de tom.

Todavia, se optarmos por considerar o verso como a inserção de uma debreagem enunciva de segundo grau, com o eu que delega a fala a um "outro", também temos mais de uma possibilidade de interpretação: podemos pensar que a voz deva ser atribuída a um sujeito externo que observa e descreve a cena para a qual o poema inteiro nos preparou, mas é plausível também considerar que a "fala" poderia ser do mesmo eu que sai de si para assumir um outro tom de voz 
e para poder tecer um comentário sobre as pessoas que observa impassíveis enquanto olham, se calam e entram no supermercado.

O que chama a atenção nesse verso é a síntese na representação da indiferença, do distanciamento emocional de ações "automatizadas". As três performances, as três transformações "narradas" resumem a atitude do indivíduo moderno que olha, mas não vê e não reage (se cala). A imobilidade representada por esses dois predicados é interrompida por uma "ação" só quando as pessoas entram no "reino" do consumo, do produto, da publicidade que é o supermercado, o lugar onde se compra e onde não é preciso pensar, nem perceber se há poesia.

Confirma-se nesse final a contraposição entre o "hoje" enunciativo e o "outrora" enuncivo: o "hoje" e o "aqui" representam o que temos, que é descrito disforicamente como banal e indiferente à poesia; o "outrora" e o "alhures" são o que não temos mais, que é euforizado porque é o sublime e elevado lugar da poesia.

O eu fala então de si mesmo e do enunciatário - que junto com ele constrói o sentido do texto e se apropria do mesmo tempo e do mesmo espaço - como sujeitos em falta, privados da “verdadeira” poesia substituída pela publicidade e pela comercialização dos indivíduos.

É essa a grande transformação da qual o texto fala: a poesia mudou de lugar e não está mais onde deveria estar. O poema coloca-se, então, como a fala de um destinador-julgador, que sanciona cognitivamente a transformação que aconteceu no lugar e, portanto, no sentido da poesia. 


\section{OCURRÍCULOE AS ATIVIDADES DIDÁTICAS}

Após ter visto exemplos dos textos e das análises semióticas que constituíram a base do nosso curso experimental, podemos esclarecer os pressupostos teóricos, com base nos quais foi elaborado o currículo, além de discutir como foram desenvolvidas e realizadas as atividades didáticas, que nos permitiram pô-lo em prática.

\subsection{AS "TAREFAS" NUM CURRÍCULOMULTIDIMENSIONAL}

Retomando a proposta de Serrani $(2005,2007)$ mencionada na introdução, definiremos o currículo adotado como "multidimensional", por não se pautar por apenas uma "dimensão", mas incluir no ensino da língua estrangeira e da análise dos textos literários diferentes caminhos, que apontam para confluências e se unem para a construção da integração.

É preciso ressaltar que o nosso curso se diferencia em alguns aspectos da proposta feita por Serrani $^{60}$. Contudo, ela nos inspirou na idealização de um percurso que pudesse abranger todos os componentes trazidos pelos textos literários e por suas análises. Além disso, tanto a ênfase dada

\footnotetext{
${ }^{60}$ Como já dissemos, Serrani propõe um currículo multidimensional formado por três componentes: 1) intercultural; 2) de língua-discurso; 3) de práticas verbais. Pelo menos, o primeiro desses três componentes não foi incluído com a mesma ênfase na nossa proposta, embora ele seja obviamente (mas indiretamente) considerado. Outra diferença importante é que no estudo de Serrani a concepção psicanalítica da subjetividade em relação ao processo de aprendizagem de línguas ocupa um papel central. Na nossa proposta operamos muito mais com a concepção de sujeito do discurso. Há mais uma questão relevante que diferencia nossos estudos baseados na semiótica francesa dos estudos de Análise do Discurso, nos quais se apóia Serrani: trata-se da questão da história e do contexto sóciohistórico, em que o discurso é produzido (cf. SERRANI, 2005: 29-37). Como já dissemos, a semiótica concentra a análise no(s) texto(s) e analisa a historicidade do sentido por meio de relações entre discursos, pois o modo de funcionamento real do discurso é que ele se constitua não sobre a realidade, mas sobre outros discursos (FIORIN, c.p.).
} 
aos aspectos discursivos da língua, quanto a importância conferida ao tratamento não dicotômico de língua e literatura são, sem dúvida, pontos de contato entre a nossa visão e as idéias dessa estudiosa.

Certo é que, na situação de ensino que estamos descrevendo, se torna impossível seguir um currículo baseado numa única progressão tal como acontece, por exemplo, no enfoque estruturalista, que procede por estruturas morfossintáticas; ou no nocional-funcional, que utiliza noções e funções semântico-pragmáticas; ou ainda no comunicativista, que reúne funções e noções para criar situações comunicativas da vida "cotidiana".

Os textos literários, que são o núcleo central das aulas e do curso, implicam, em primeiro lugar, que sejam abordados "temas" e estruturas lingüísticas, vistas em seu funcionamento discursivo, pelo qual se evidencia o componente "língua-discurso", no sentido da relação entre a materialidade lingüística, o sistema da língua e o discurso.

Isso significa, ademais, que, embora a seleção dos textos literários utilizados leve em conta também as estruturas lingüísticas neles presentes, a progressão não deriva da "gramática", que está nos textos, inclusive aparecendo com funções diferentes, que são observadas e confrontadas, enriquecendo a cada nova análise e a cada novo texto os conhecimentos dos aprendizes.

Ocuparam um lugar importante também as reflexões sobre os gêneros, que o texto literário introduz, e a maneira como eles podem ser identificados e estudados, a partir da observação de recorrências, analogias e diferenças nos mecanismos lingüísticos e nos traços distintivos que caracterizam as construções textuais dando vida às formas dos discursos. 
Além de tudo isso, há o percurso que os alunos realizam em direção à construção autônoma do seu saber e da sua relação cada vez mais independente com os textos, a leitura, a descrição, a interpretação e o sentido e, portanto, com a língua estrangeira como um todo, pensando na funcionalidade discursiva da "gramática", na comunicação como descoberta das possibilidades dos atos lingüísticos, que acontece paralelamente à tomada de consciência dos mecanismos que regem o funcionamento da língua.

A análise de textos literários permite trabalhar simultaneamente todos esses aspectos, sem privilegiar nem negligenciar nenhum, ainda mais porque foi entendida como "tarefa" (task), isto é, como uma atividade, cujo objetivo não se limita à aprendizagem da língua estrangeira, prevendo, ao contrário, finalidades mais amplas que contribuem para uma formação integral do aluno.

O conceito de "tarefa" nasce no âmbito das pesquisas sobre aquisição, aprendizagem e ensino de línguas estrangeiras e já foi tema de inúmeros ensaios e livros ${ }^{61}$. No entanto, não há uma definição unívoca e válida para todos os contextos, pois muitas vezes os pesquisadores acabaram acrescentando ou eliminando aspectos estabelecidos em outros estudos e privilegiando as características que julgavam mais relevantes para suas reflexões.

O que importa é que o task-based approach ("ensino por tarefas") se opõe às formas tradicionais de ensino/aprendizagem de línguas estrangeiras, nas quais, muitas vezes, a prática

\footnotetext{
${ }^{61}$ Ver, entre outros, NunAN, 1989; PARRott, 1993; Willis, 1996; SKEHAN, 1998; ByGATE/SKEHAN/SWAIN, 2001; ROBINSON, 2001b.
} 
descontextualizada de estruturas lingüísticas ou de situações artificiais (inclusive as ditas “comunicativas") acabava prevalecendo, transformando o aluno num mero repetidor de formas gramaticais, de expressões fixas e de um léxico pré-estabelecido, por meio dos quais deveria chegar ao domínio da língua estrangeira.

Numa direção contraposta a isso, os estudiosos que refletem sobre a "tarefa" no ensino de línguas enfatizam, antes de mais nada, que toda atividade realizada em sala de aula precisa ser executada para alcançar um "resultado concreto" (outcome) ao qual se chega utilizando a língua estrangeira. Em outras palavras, a aquisição/aprendizagem da língua estrangeira não acontece só por meio da prática de estruturas e funções (como quando, por exemplo, o aluno faz um exercício para praticar uma determinada estrutura gramatical ou elabora um "diálogo" para treinar uma específica função lingüística), mas é inserida num processo mais abrangente e múltiplo de construção de objetivos.

A primeira conseqüência disso é que toda a língua que os alunos "produzem" será $a_{\text {autentica }}^{62}$, isto é, criada para uma efetiva comunicação de conceitos e conteúdos e não apenas para reproduzir situações artificiais. Assim a língua estrangeira é praticada enquanto se desenvolvem competências e habilidades muito mais amplas, em atividades exigentes, mas que os alunos têm condições de levar a termo, inclusive porque motivados por um contexto em que o

\footnotetext{
${ }^{62} \mathrm{O}$ conceito de autenticidade é um dos mais debatidos e polêmicos no âmbito do ensino/aprendizagem de línguas estrangeiras. Fala-se em autenticidade em primeiro lugar para definir um insumo (input) que não é, como já dissemos, criado para fins didáticos nem alterado para eliminar dificuldades. Aqui estamos entendendo autenticidade, no sentido de "língua utilizada para uma finalidade não artificial", ou seja: os alunos falam e comunicam para obter algo real, diferente do que pode acontecer quando o aluno "finge" uma determinada situação para treinar uma estrutura lingüística. Nesse sentido, embora concordemos com os que afirmam que língua é intrinsecamente cultura (ver VEDOVELLI, 2002: 118), acreditamos que a língua para comunicar "de verdade" possa criar uma efetiva motivação.
} 
óbvio é substituído pelo desafiador; o artificial pelo "autêntico"; o facilitado, pelo complexo, estimulando-os a participar ativamente.

O Quadro europeu comum de referência para as línguas (QECR) introduz o conceito de "tarefa", dizendo que sua execução

envolve a activação estratégica de competências específicas, de modo a realizar um conjunto de acções significativas num determinado domínio, com uma finalidade claramente definida e um produto (output) específico (2001: 217).

Os aprendizes são, portanto, envolvidos na "tarefa" em nível pessoal e sua contribuição é altamente significativa para o desenvolvimento das atividades em sala de aula. Por causa disso, as atividades realizadas não serão nunca duas vezes idênticas a si mesmas, já que a cada execução a participação dos discentes irá produzir mudanças e reinterpretações do que foi proposto pelo professor.

Mais uma característica da "tarefa" é que o sentido está no centro do processo e possui uma relevância primordial (ver SKEHAN, 1998: 95). Os aprendizes devem compreender, negociar e expressar sentidos - e não reproduzir sentidos de outros - de modo a apropriar-se da língua e vivenciá-la em uso.

No entanto, embora o sentido seja essencial, chega-se a ele através da forma (veremos isso com detalhes mais à frente) e, portanto, é preciso manter “um equilíbrio instável entre a atenção 
prestada ao sentido e à forma ${ }^{63}$ [...]" (QECR, 2001: 218). Em outras palavras, espera-se que os aprendizes descubram o sentido dos textos (do insumo, do input) e de suas próprias produções lingüísticas, levando em conta como e por quais estruturas lingüísticas eles foram realizados.

Essencial num currículo em que o ensino/aprendizagem é baseado em "tarefas" é, então, que sentido e formas lingüísticas, plano do conteúdo e plano da expressão, sejam elaborados contemporaneamente, superando e integrando abordagens que privilegiam ora um, ora outro aspecto (aspectos só lexicais, ou só morfossintáticos, ou só culturais e interculturais, ou só escritos, áudio-visuais, orais, etc.). A idéia-guia é que o objetivo final de todo o percurso de aquisição/aprendizagem de uma língua estrangeira é a autonomia do aprendiz, que deverá desenvolver cada vez mais suas potencialidades, para poder usar fora da sala de aula não só a língua, mas também todas as competências e os conteúdos que fazem parte do seu percurso de formação.

Há mais um aspecto que é considerado característica constitutiva de uma "tarefa" e que precisa ser lembrado para completar sua definição: é essencial que ela tenha relações com atividades da "vida real", diferentemente do que muitas vezes acontece nas atividades lingüísticas na sala de aula de língua estrangeira, que, no lugar de trazer para a "escola" o mundo, se afastam dele, transformando-se em repetições, cujo sentido não ultrapassa a prática de um aspecto limitado da língua.

\footnotetext{
${ }^{63}$ Em semiótica, não se opõe sentido a forma, pois há forma e substância da expressão e do conteúdo. O que aqui se chama "forma" é a materialidade lingüística, a expressão que veicula os sentidos.
} 
Cabe aqui uma observação sobre o que entendemos por "vida real", pois, hoje, ainda na esteira do que foi propagado pelo "comunicativismo", se considera muitas vezes que aspectos da “vida real" são apenas os que dizem respeito a situações de comunicação corrente e utilitária. Entretanto, nossa "vida real" não é constituída apenas por situações desse tipo e não são raras as ocasiões nas quais nossas "necessidades lingüísticas" vão muito além das fórmulas ou das estruturas fixas por meio das quais podemos, por exemplo, pedir algo ou falar do que fazemos durante o dia.

O caso dos alunos de um curso de Letras pode bem exemplificar isso: para eles a atividade de ler e analisar textos é certamente parte do "cotidiano", já que está presente nas aulas de várias disciplinas, se estende a outros momentos de sua formação e provavelmente de sua vida particular e continuará presente em sua futura vida profissional, em que os textos e a literatura serão essenciais.

Diversas vezes até aqui mencionamos as competências e as habilidades lingüísticas indispensáveis na aquisição/aprendizagem de uma língua estrangeira. Com efeito, são várias as competências de que precisamos para produzir (e interpretar) enunciados e que nos permitem "fazer" e "ser" linguisticamente por meio de textos e de discursos.

"Saber", "saber fazer" e "saber ser" na língua estrangeira são, de fato, as finalidades últimas da educação em língua estrangeira assim como foram definidas na terminologia adotada 
pelo $\mathrm{QECR}^{64}$, que prevê a aprendizagem de um “saber" relativo à (inter)cultura e às estruturas da língua alvo, para poder garantir a realização do indivíduo.

O QECR dedica um capítulo inteiro ${ }^{65}$ à questão das competências que devem ser adquiridas ao aprender uma língua e menciona desde as mais propriamente lingüísticas (que denomina “comunicativas”) até as competências sócio-lingüística e pragmática.

Descrevendo o que são as “competências lingüísticas”, o QECR detalha seus componentes lexical, gramatical (morfológico e sintático), semântico, fonológico, ortográfico e ortoépico, e mostra, dessa forma, que leva em conta a importância do sistema da língua e de suas "regras", indispensáveis para produzir enunciados gramaticais e aceitáveis para a realização da "comunicação".

Há depois a competência "sócio-lingüística" que inclui, ainda segundo o QECR, as normas sociais, as diferenças de registro e de variedades lingüísticas, além do conhecimento de fórmulas fixas da "sabedoria popular", que "exprimem e reforçam as atitudes correntes" (QECR, 1991: $170)$.

Explica-se em seguida o que é competência "pragmática" dizendo que é relativa ao conhecimento dos princípios básicos de como as mensagens são organizadas, estruturadas e adaptadas ao contexto ("competência discursiva"); de como são usadas para realizar funções

\footnotetext{
${ }^{64}$ De uma forma parecida, também a UNESCO define as finalidades da educação em geral como "aprender a conhecer", "aprender a fazer", "aprender a viver (junto)" e "aprender a ser". Cf. DELORS (1996).

${ }^{65}$ Trata-se do capítulo 5 do QECR (2001: 147-184).
} 
comunicativas ("competência funcional"); de como são seqüenciadas de acordo com esquemas de interação ("competência de concepção") (QECR, 1991: 174).

Essa descrição das competências deixa transparecer que a idéia subjacente ao QECR, em sua interpretação do aspecto "discursivo" da língua, ignora a dimensão enunciativa, concentrando-se, ao contrário, em características da comunicação muito mais ligadas às necessidades "práticas" e cotidianas. Também, ao relacionar as competências, o QECR parece desconsiderar aquelas necessárias para ler, descrever, analisar, interpretar e produzir textos (não só literários).

Acontece, porém, que num percurso no qual a aprendizagem da língua se une à aprendizagem da leitura e da análise de textos literários, as competências citadas deverão ser integradas com outras competências, que julgamos essenciais.

Com efeito, se entendemos que, conhecendo uma língua, podemos "criar" mundos através dela e se queremos estar no mundo do discurso e poder "agir" produzindo e interpretando a língua que o constitui, precisamos também considerar a relevância de uma acepção de competência discursiva diferente da citada acima, além de acrescentar também as competências interdiscursiva, textual e intertextual.

$\mathrm{Na}$ definição que adotamos aqui, a competência discursiva inclui uma competência narrativa, por meio da qual se identificam as transformações no texto, que são utilizadas também na construção das próprias narrações, além de uma competência discursiva propriamente dita, que diz respeito ao saber reconhecer e usar no discurso, por um lado, temas e figuras e, por outro, 
as categorias de pessoa, tempo e espaço. Faz parte ainda da competência discursiva saber reconhecer os mecanismos argumentativos como, entre outros, a citação dos discursos alheios e a individuação e criação dos efeitos de sentido.

A competência interdiscursiva é a competência relativa à heterogeneidade constitutiva do discurso. A consciência dessa característica que faz parte de todos os discursos é essencial para a elaboração de discursos próprios e para a compreensão e interpretação dos alheios. A competência interdiscursiva inclui também as competências cultural, intercultural e ideológica, próprias de uma determinada língua e de um determinado país e, portanto, essenciais quando se aprende uma língua estrangeira, cuja "cultura" se constrói lingüisticamente.

Há também a competência textual, que concerne ao saber utilizar as estruturas de manifestação (no nosso caso, em primeiro plano, a língua natural estudada), enquanto a competência intertextual é aquela pela qual se aprende a identificar as relações de um texto com outros textos, num diálogo a partir do qual nascem novos sentidos plausíveis e novas interpretações possíveis. ${ }^{66}$

O objetivo do (per)curso planejado foi a aquisição dessas competências, tanto para a sala de aula, quanto - e principalmente - para fora dela. Procuramos assim criar as condições para uma educação, simultaneamente, lingüística e literária que pudesse propiciar a formação de leitores conscientes das possibilidades da linguagem e motivados a sempre interrogar-se sobre o sentido dos textos; que pudesse treinar a capacidade de os alunos reconhecerem as maneiras como se dá a significação entendida como produção de sentido; que pudesse ajudá-los a desvelar o

\footnotetext{
${ }^{66}$ A referência para essa visão das competências encontra-se em FioRIN (1996a: 32-33; 56-57).
} 
funcionamento da língua e as peculiaridades da língua literária, que podem ser encontradas também em outros tipos de texto; que pudesse também permitir que os alunos aprendam a descobrir a poeticidade nos textos e como está relacionada com as potencialidades da língua; que pudesse preparar para o desenvolvimento de uma relação cada vez mais autônoma com a língua e com os textos.

\subsection{AS ATIVIDADES DIDÁTICAS: UM PERCURSO DA LEITURA À ESCRITA}

Vejamos agora de que maneira os pressupostos citados entraram concretamente na sala de aula e como, nas atividades didáticas, procuramos considerar a complexidade que a aquisição/aprendizagem de uma língua estrangeira constitui, especialmente se estiver unida à aquisição de competências e habilidades específicas que levem os discentes a saber ler, descrever, analisar e interpretar textos poéticos.

Como antecipamos na introdução, as análises semióticas dos textos literários apresentadas no capítulo 1 serviram como base para a elaboração das atividades didáticas ${ }^{67}$. Nelas foi construído um percurso da recepção à produção, do input ao output, da leitura à escrita, passando pela compreensão e pela descoberta das estruturas organizadoras dos textos e dos mecanismos próprios do funcionamento da língua, graças aos quais se percebe não apenas o que os textos significam, mas como eles significam.

\footnotetext{
${ }^{67}$ As atividades didáticas utilizadas para os seis textos examinados neste trabalho foram reproduzidas integralmente (ver anexo I).
} 
Nesse contexto, "ler" possui um sentido muito mais amplo do que aquele que lhe é normalmente atribuído e, para defini-lo, é útil relembrar, como faz Julia Kristeva, os significados que esse verbo tinha para os Antigos, para os quais “'ler' era também 'recolher', 'apanhar', 'espiar', 'reconhecer as pegadas', 'tomar', 'roubar'”, indicando “uma participação agressiva, uma ativa apropriação do outro"68. Era assim que se configurava o percurso realizado nas aulas, nas quais a partir dessa leitura vista como "apropriação" se chegava à escrita.

O ponto de partida, o insumo inicial (input) era sempre o texto literário (poético) e o "resultado", ao qual a execução da "tarefa" devia levar, era a análise oral e escrita desse mesmo texto, que se concretizava na produção escrita final (output) de cada um dos alunos. Para fazer isso, o insumo devia transformar-se em "insumo absorvido" (intake) e isso acontecia também por meio de "instruções" que, guiando o olhar e a escuta, permitiam que os alunos "notassem" (noticing) as peculiaridades daquele texto e as estruturas lingüísticas por meio das quais se construía o sentido.

O contato com textos literários favorece em si uma "demora" na forma do conteúdo, pois, como afirma Lopes,

ao lidar com o estético em qualquer de suas manifestantes, somos forçados a desacelerar nossa atenção para com o plano da expressão, contrariamente ao que costumamos fazer na comunicação corriqueira e utilitária do dia-a-dia (2003: 67).

68 “'Lire' était aussi 'ramasser', 'cueillir', 'épier', 'reconnaître les traces', 'prendre', 'voler' [...] dénote, donc, une participation agressive, une active appropriation de l'autre.” (KRISTEVA, 1969: 120). 
Acresce a isso que, por meio de atividades dirigidas, o ensino formal pode contribuir para o desenvolvimento das competências do aprendiz, indicando-lhe como e $o$ que observar nos textos. Dessa maneira, o sentido continua sendo a finalidade última, que se alcança, porém, por meio da análise das formas lingüísticas pelas quais o sentido se manifesta.

Reflexões dessa natureza são as que guiam os teóricos do "foco na forma" (focus-onform $)^{69}$, que se afirma em reação, por um lado, à concepção de um ensino/aprendizagem baseado em estruturas gramaticais isoladas ("foco naS formaS" - focus-on-formS), e, por outro, a uma organização das aulas que, procurando reproduzir o ambiente de aquisição da língua materna, dirige-se apenas ao sentido, ignorando de todo a gramática, a aparência lingüística e sua observação no interior do texto ("foco no sentido" - focus on meaning).

Está em jogo acreditar ou não na aprendizagem explícita da língua, isto é, no papel que possui nesse processo a tomada de consciência (consciousness-raising) dos mecanismos de funcionamento da língua, para os quais pode ser dirigida a atenção dos aprendizes por meio de instruções específicas, próprias do contexto de ensino formal, que é o contexto ao qual nos referimos e que perderia sua função ou deveria ser completamente reformulado, se a aprendizagem acontecesse apenas em condições "naturais".

De fato, enquanto Krashen $(1982,1985)$ e seus seguidores negaram a interface entre a aquisição implícita e a aprendizagem explícita, declarando que a gramática se aprenderia

\footnotetext{
${ }^{69}$ Sobre essa questão, ver LONG (1991, 1997), LONG/ROBINSON (1998) e DOUGHTY/WiLliAMS (1998) e ORTEGA (2001). A maior parte desses estudos foram publicados em inglês e, portanto, a terminologia específica acabou fixando-se nessa língua. Como já dissemos, para a tradução para o português nos baseamos no Glossário de Lingüistica Aplicada (AlmEIDA Filho/SCHMITZ, 1998), o qual, porém, não contempla todos os termos utilizados, indicando que eles ainda não possuem uma tradução consolidada. Decidimos, portanto, para maior clareza, que as traduções seriam seguidas pela designação em inglês.
} 
unicamente de forma incidental e que a aquisição de uma língua deveria ser "natural"70, outros estudos comprovaram que existe uma ligação entre as duas formas de apropriação da língua estrangeira, de modo que, se é verdade que uma parte do insumo pode ser percebida independentemente de qualquer indicação vinda de fora, é também verdade, que a instrução formal leva os aprendizes a atentar para determinados fenômenos lingüísticos ${ }^{71}$, especialmente quando esses serão necessários para realizar a "tarefa", o que significa, no nosso caso, entender melhor o texto de partida e poder expressar as próprias hipóteses interpretativas em relação ao próprio texto.

Defender o "foco na forma" significa, em suma, crer que gramática e estruturas lingüísticas precisam estar presentes na organização de aulas e cursos, sem, contudo, ser o único elemento que guia docentes e discentes. As formas surgem a partir do insumo inicial (o texto) e das necessidades dos alunos, os quais para entender os textos e para formular suas idéias em língua estrangeira precisarão de determinadas estruturas lingüísticas, que serão levados a "procurar" e a "querer aprender" durante as aulas.

Assim como a entendemos aqui, a "tarefa" induz, portanto, a perceber a forma e leva ao noticing (ELLIS, 2003), por meio de uma atenção dirigida a determinados aspectos lingüísticos. Realiza-se assim um processo cognitivo que implica a conscientização da co-relação entre forma e sentido e a reflexão sobre a funcionalidade discursiva dos fatos gramaticais, de modo que a

\footnotetext{
${ }^{70}$ Referimo-nos aqui à abordagem chamada "Natural Approach" que se funda no aparato teórico elaborado por Krashen. Para uma revisão das principais características dessa abordagem, ver LONGO (1998: 253-266).

${ }^{71}$ Long (1983) é um dos primeiros a defender a superioridade da aquisição/aprendizagem em sala de aula, que inclusive aceleraria o processo de aproximação da segunda língua, sem alterar a "ordem natural”, mas permitindo chegar a níveis que seria difícil, se não impossível, alcançar de outra forma. Long acrescenta, porém, que é preciso distinguir entre os diversos tipos de instrução. Eles não são equivalentes e o "foco na forma" é, segundo ele, o tipo de organização das aulas que mais pode ter sucesso.
} 
"gramática" acaba tendo relevância não apenas em si, mas pelos efeitos de sentido que produz, além de contribuir para a realização de uma busca das relações significativas no interior do texto.

Ao mesmo tempo, tanto na recepção cada vez mais consciente do texto literário, quanto na produção cada vez mais motivada dos aprendizes, a língua estrangeira é aprendida, descoberta e desenvolvida e são adquiridas competências e habilidades em vários níveis.

Há mais uma questão sobre a qual precisamos deter-nos um pouco mais. Trata-se da já citada questão da passagem do insumo (input) ao insumo absorvido (intake) e desse à produção dos discentes (output). Concentrar-nos-emos agora principalmente na última parte do movimento, isto é, na produção.

Já dissemos acreditar no contato com os textos poéticos em conjunto com atividades didáticas específicas como meio que propicia a elaboração do input lingüístico num nível profundo e, portanto, a sua "absorção" (intake), num movimento em que o conhecimento explícito e consciente da língua estrangeira se une ao conhecimento implícito e incidental.

Ora, cabe dizer que esse é apenas o primeiro passo, pois acreditamos ser a produção em língua estrangeira o principal instrumento por meio do qual o aprendiz pode reorganizar e integrar tudo o que foi observado e adquirido porque a produção pode ter a função de "mola que força o aprendiz a prestar atenção aos meios de expressão dos quais precisa para transmitir com sucesso o sentido pretendido". ${ }^{72}$

\footnotetext{
72 "[...] trigger that forces the learner to pay attention to the means of expression needed in order to successfully convey his or her own intended meaning." (SWAIN, 1985: 249)
} 
A produção funciona, portanto, como mecanismo para interiorizar os elementos presentes no processo de aquisição/aprendizagem. Com efeito, foi demonstrado em vários estudos (ver, entre outros, SWAIN, 1985 e 1998) que a exposição à língua significativa, por muitos considerada suficiente para a aquisição/aprendizagem de uma língua estrangeira, de fato não o é e, embora necessária, não basta a assegurar um desenvolvimento da língua estrangeira que possa aproximarse de competências e habilidades complexas.

Assim, diferente da idéia defendida por Krashen (1981, 1985), julgamos que a língua não possa ser aprendida apenas por meio do "insumo compreensível” (comprehensible input), representado pela conhecida fórmula $i+1$, que resume a convicção segundo a qual, no insumo proposto ao discente, poderia haver só uma dificuldade por vez.

Também consideramos que essa afirmação contém ao menos dois problemas sobre os quais é preciso refletir. Por um lado, se Krashen defende, como dissemos antes, que a aquisição é implícita, torna-se praticamente impossível saber qual é o nível de conhecimento dos aprendizes para poder acrescentar apenas uma dificuldade de cada vez e evitar, portanto, que o texto obrigue o aluno a um "esforço excessivo"; por outro lado, mesmo se fosse possível identificar exatamente qual o nível de cada um dos aprendizes, para poder propor toda vez um insumo que não exceda um "aceitável” nível de dificuldade, seria provavelmente necessário modificá-lo e adaptá-lo, contrapondo-se dessa forma à idéia da aquisição "natural”, defendida pelo próprio Krashen.

Mais uma questão merece ser mencionada: trata-se das diferenças individuais e dos estilos cognitivos de aprendizagem que se manifestam de formas peculiares em cada indivíduo e impedem generalizações adaptáveis a todos os aprendizes (cf. SKEHAN, 1994: 19-38). Um docente que queira saber qual o nível de dificuldade para o qual o seu grupo de alunos está 
preparado e que, portanto, pode propor em sala de aula, estará provavelmente fadado a nunca encontrar uma resposta satisfatória e uma solução realmente eficaz, pois haverá sempre no grupo um elevado número de variáveis e divergências entre os indivíduos que o constituem.

Na nossa prática de ensino o insumo é cuidadosamente selecionado, mas, contrariamente a quanto postulado por Krashen, consideramos que o "natural" é, por sua própria natureza, complexo e que, portanto, poderá/deverá conter mais do que uma única dificuldade de cada vez.

Importante é que os aprendizes construam em seu percurso estratégias e conhecimentos suficientes para enfrentar essas dificuldades, preparando-se assim para a autonomia lingüística necessária e para a complexidade que é da língua, dos textos, dos discursos e da vida e integrando a compreensão e a produção, a exposição à língua e seu uso, a interpretação das estruturas e sua utilização para alcançar seus objetivos.

A produção (o output) é considerada, nessa maneira de ver, não só como a manifestação daquilo que os alunos já aprenderam, mas sim como um instrumento para ativar a aquisição/aprendizagem da língua estrangeira:

Ela [a produção] constitui não só o produto da aquisição ou o meio para praticar a língua e conseguir maior fluência, mas também um potencial fator causador do processo de aquisição ${ }^{73}$.

$\mathrm{Na}$ hora de "produzir língua" os alunos podem, de fato, utilizar os conhecimentos adquiridos, interiorizando-os e fortalecendo sua base de conhecimento para receber novos

\footnotetext{
73 "It [the output] constitutes not only the product of acquisition or the means to practice one's language for greater fluency, but also a potential causal factor in the acquisition process" (IZUMI, 2002: 545).
} 
conteúdos (cf. SWAIN/LAPKIN, 1995). Ademais, a experiência de escrever e falar em língua estrangeira proporciona aos aprendizes a possibilidade de notar onde há incertezas ou elementos faltantes no conhecimento da língua e de seu uso e de perceber, portanto, onde e como agir para tornar-se mais “competentes" na língua estrangeira.

É preciso, porém, deixar claro que não há simetria entre o insumo e a produção. Muitos estudos, inclusive pertencentes às linhas de pesquisa mais diversas, concordam em afirmar que não é possível verificar a existência de uma ligação direta entre o que é proposto em termos de insumo e o que é realmente aprendido ${ }^{74}$ e que, portanto, é ilusório pensar em prever exatamente o que os alunos poderão adquirir.

As instruções e as indicações dadas em sala de aula, numa situação em que os alunos são ativos e motivados, aceleram a aprendizagem e aumentam as possibilidades de percepção de determinados aspectos da língua que podem posteriormente entrar no repertório ativo do aprendiz, sem que se possa, todavia, garantir quando e de que maneira isso acontecerá.

Além disso, a aquisição/aprendizagem de uma língua estrangeira é instável, pois novos elementos lingüísticos não são simplesmente adicionados aos já presentes, mas provocam, ao contrário, uma alteração e uma reestruturação de todo o sistema interlingüístico, que pode inclusive desembocar num momentâneo decréscimo da performance lingüística, depois do qual

\footnotetext{
${ }^{74}$ Cf. D’Addio Colosimo (1996: 99).
} 
se realiza geralmente uma assimilação do(s) elemento(s) novo(s) e uma estabilização do sistema, de modo que a produção pode voltar a subir ${ }^{75}$.

De qualquer maneira, como já explicamos, uma das convicções que nos guiou na hora de elaborar as atividades foi que elas deviam propiciar o contato entre o texto de partida e os alunos, privilegiando a produção destes últimos e permitindo o reconhecimento "consciente" dos mecanismos da língua e dos textos, pois tomar consciência do funcionamento das estruturas lingüísticas favorece sua entrada na expressão oral e escrita, vista como o momento em que se concretiza a aprendizagem da língua estrangeira (cf. SCHMIDT/FrOTA, 1986).

Levando isso em consideração, as atividades foram planejadas de modo a oferecer ao menos dois diferentes momentos para a produção:

1. durante as aulas previu-se o que chamamos output parcial, algumas vezes individual, com mais freqüência em duplas ou grupos e depois com a classe, para oferecer aos alunos a possibilidade de realizar uma primeira verificação de sua capacidade de "produzir língua" tanto por escrito, quanto oralmente;

2. no final de cada ciclo de aulas, a produção escrita individual representava uma sorte de output global, em que cabia ao aprendiz realizar uma produção escrita, dirigida pelas atividades já executadas em sala de aula, às quais o aluno podia, todavia, acrescentar novos elementos.

\footnotetext{
${ }^{75}$ Fala-se em geral de uma curva em U para definir esse processo. Para um aprofundamento dessa questão, ver, entre outros, o artigo de MCLAUGHLIN (1990).
} 
Voltaremos com mais detalhes às diferentes fases em que se articulava o trabalho em sala de aula, mas, antes de descrever sua execução, precisamos definir quais eram os objetivos da análise e os conceitos sobre os quais foram baseadas as atividades didáticas, além de indicar mais algumas características gerais a partir das quais se deu sua elaboração concreta e sua estruturação.

Em primeiro lugar, cabe relembrar que cada atividade foi proposta aos alunos como "tarefa" (task), isto é, ligada ao (saber) fazer língua, que não visa apenas à prática de um ou vários aspectos da gramática da língua estrangeira, mas sim a alcançar um objetivo "concreto" e "verdadeiro" - o resultado do qual falamos ao explicitar o que é uma "tarefa" - baseando-se sempre no sentido como elemento essencial e utilizando as formas lingüísticas e o seu funcionamento discursivo como meios para chegar ao sentido.

Foram assim elaboradas atividades, cuja finalidade era guiar os alunos a perceber, no interior do texto, as relações e tudo aquilo que poderia ser significativo, ajudando-os, portanto, a ver os aspectos relevantes do texto que estavam analisando e assim a perseguir caminhos de leitura e interpretação.

$\mathrm{Na}$ formulação das questões de nossas atividades didáticas evitamos nomear diretamente uma estrutura lingüística determinada pedindo que os alunos a individuassem no texto ${ }^{76}$.

\footnotetext{
${ }^{76}$ Em diversas metodologias ainda hoje muito utilizadas, os textos são selecionados porque contêm uma determinada estrutura gramatical que o professor quer apresentar. Acontece, portanto, que, após algumas atividades de "compreensão de texto", se passa a buscar nele aquela específica estrutura que os alunos deverão sublinhar ou evidenciar de alguma maneira, para poder depois procurar regularidades e chegar à definição de uma regra. Parecenos que o texto, em situações de ensino como essa, acaba sendo apenas um "pretexto", pois o objetivo principal da aula de língua estrangeira continua sendo a "regra gramatical".
} 
Procuramos, ao contrário, orientá-los em direção à busca de uma função discursiva, de um efeito de sentido, de uma categoria de organização do texto, de relações que permitissem identificar, entre outras coisas, como se constroem a temporalização, a espacialização e a actorialização, ou como se reconhecem, pelas recorrências no texto, os temas e as figuras.

Por isso, preferimos em geral formular nossas perguntas utilizando, por exemplo, a categoria tempo ou mencionando a temporalização sem maiores especificações e pedir que os alunos encontrassem elementos significativos nos textos ainda sem saber seu "nome", de modo que viesse deles a "necessidade" de nomeá-los e de entender seu funcionamento, para poder apreender melhor o sentido do qual essas estruturas lingüísticas eram portadoras e expressar com mais propriedade suas interpretações.

Permanecendo ainda no exemplo do tempo, é preciso dizer que citá-lo genericamente e deixar que os alunos observassem por meio de quais elementos se construía implicou também não conduzi-los em busca de um tempo verbal pré-determinado ou de uma específica estrutura, impondo assim limites ao olhar, mas levá-los a notar as relações entre os diversos planos temporais e desses com outros elementos relativos ao tempo (advérbios de tempo, cronônimos, aspectualização, etc.), que contribuem para a organização da temporalidade do texto e para a constituição de efeitos de sentido.

Uma outra característica das atividades didáticas é que elas foram elaboradas de modo a apresentar recorrências na estruturação, para permitir que os alunos adquirissem familiaridade com um determinado modelo de organização do trabalho de análise do texto. Nessa escolha apoiamo-nos em estudos segundo os quais conhecer o tipo de "tarefa" facilita o papel do discente 
e permite que ele se dedique melhor ao desenvolvimento das diferentes fases do trabalho (cf. Bygate, 2001; RoBinson, 2005; KUIKEN et al., 2005). Não obstante, cada atividade possuía suas peculiaridades que refletiam as particularidades do texto, pois "o texto, na realidade, dita sua lei" (BERTRAND, 2003: 72).

Procuramos também avançar gradativamente, introduzindo a cada nova análise elementos desafiadores e acrescentando a observação de mais algum aspecto do texto, embora a base permanecesse essencialmente a mesma e os alunos pudessem dessa maneira orientar-se na execução de uma "tarefa" conhecida.

Pelo que concerne à semiótica, os instrumentos de análise e a metalinguagem específica também foram incluídos paulatinamente, conforme se faziam necessárias definições mais precisas e conforme, ao longo dos semestres, os alunos iam apropriando-se tanto dos instrumentos de análise, quanto da língua estrangeira, podendo construir e afirmar seu lugar no momento da realização das análises dos textos.

O uso da metalinguagem da semiótica não estava entre os objetivos principais do curso. No entanto, diversas vezes percebemos que a introdução de conceitos mais exatos poderia trazer proveito e contribuir para tornar mais claras as referências teóricas e possibilitar, portanto, um “diálogo" sobre os textos a partir de um repertório comum.

Como já dissemos na introdução, no desenvolvimento das atividades didáticas foi privilegiado o nível das estruturas discursivas, que é o nível complexo da superfície do texto e, portanto, o mais estritamente ligado às diferenças entre as línguas naturais, além de ser "aí que o 
enunciador fixará as grandes oposições que atravessarão toda a obra e garantirão sua homogeneidade [...]" (FLOCH, 2001: 15).

De fato, o nível discursivo mostra, tanto sintática quanto semanticamente, marcas mais explícitas das escolhas do sujeito da enunciação, especialmente nas categorias de pessoa, tempo e espaço e, também, nos temas e nas figuras que apontam para determinações sociais e históricas e permitem descobrir as formações ideológicas que estão por trás do texto, mostrando aspectos da cultura que o produziu (essencial quando se está em contato com uma língua e uma literatura estrangeiras).

Uma das perguntas recorrentes dizia respeito ao tema, termo muito "prático", pois cobre uma ampla gama de conceitos. Como escreve Bertrand, “a comodidade dessa noção está assentada decerto no caráter difuso de sua definição", o que, por outro lado, torna instável a delimitação de sua abrangência, que "oscila entre os topoi (a paisagem, por exemplo, como signo cultural da Natureza) e os motivos axiológicos (como 'a decadência')" (2003: 212).

Pedir aos alunos que reconhecessem e procurassem definir o "tema" do texto significava desencadear um processo de busca das recorrências e das isotopias mais abstratas que percorrem os conteúdos figurativos.

Aparecia assim o conceito-chave de isotopia, essencial quando se pensa em como descrever o sentido de um texto e em estabelecer progressivamente as condições de uma interpretação plausível, pois a isotopia garante a coesão do texto e do enunciado e comanda a significação global. 
É preciso dizer que, embora tenhamos privilegiado o nível discursivo, reservamos um espaço também à identificação das oposições categoriais do nível fundamental, a partir das quais surge o sentido, e utilizamos os conceitos de euforia e de disforia porque neles se articula a categoria tímica, que transforma microuniversos em axiologias, nas quais a valorização positiva (eufórica) se contrapõe à negativa (disfórica), fornecendo a base para uma reflexão sobre termos contrapostos e sobre diferenças.

Mais uma constante nas atividades consistia na proposta de segmentação do texto, que, fundada em diferentes critérios, visava a facilitar a verificação dos mecanismos de sua construção e a mostrar com maior clareza procedimentos de organização textual. Com efeito, segmentar um texto e dividi-lo em seqüências permite relevar até visualmente mudanças temáticas, espaciais, temporais, etc. e perceber a partir de quais estruturas lingüísticas elas podem ser identificadas.

Já citamos a categoria tempo, que teve um papel central em nossas atividades didáticas. As outras duas categorias que fundam a sintaxe do nível discursivo (espaço e pessoa) também foram parte importante da análise, tendo, contudo, maior ou menor relevância conforme sua produtividade para o texto que se estava considerando.

De qualquer maneira, havia sempre questões dedicadas à espacialização em que se pedia aos alunos que observassem, descrevessem e interpretassem, não só como aparecia o "espaço" no texto, mas também qual era o ponto de vista escolhido pelo enunciador que se "posicionava" por meio do observador e, sobretudo, para quais efeitos de sentido essas escolhas apontavam. 
Por outro lado, considerar a actorialização, além de possibilitar a análise do ator no texto e da maneira como se configurava e se mostrava, levava também a reflexões sobre o narrador e o enunciador. Eram assim introduzidas questões que procuravam sensibilizar os discentes para com a relação entre enunciado e enunciação, indispensável na leitura e na compreensão não só de um texto literário, mas de qualquer tipo de texto.

A conscientização de que há sempre um enunciador, isto é, um eu expresso ou não, por trás de todos os textos, mas que esse eu não corresponde ao autor em carne e osso, ao escritor que assina a obra, fez com que os alunos olhassem com mais distanciamento para os mecanismos de construção dos textos e dos discursos.

De fato, a semiótica não se interessa pelo autor ontológico, mas procura dentro do texto os indícios que permitem reconstruir um enunciador, visto que, na análise semiótica, "não se levará em conta nenhuma informação sobre o autor, sua ideologia ou sua competência que não esteja contida no texto" (FLOCH, 2001: 16) e que o texto será considerado como objeto que garante em si sua legibilidade, no qual, como já mostramos na introdução, o sentido se alcança por meio de uma análise interna.

A partir daí, ganha relevância estudar as diversas instâncias que participam da organização e da disposição do espaço enunciativo e que, ligadas à dimensão do discurso, guiam o acesso do leitor aos modos de produção de sentido.

Ao observar como está organizado no texto o aparecimento de ator(es) e narrador(es), a atenção dirige-se também às debreagens e às embreagens, à perspectiva, ao observador, além de 
tornar-se fundamental refletir sobre a citação no texto realizada por meio de discurso direto (em que o narrador marca a separação entre a sua voz e a voz do interlocutor), indireto (onde o narrador se apropria do outro e suprime as marcas que o identificam) e indireto livre (em que não há barreiras nítidas entre as vozes do narrador e do interlocutor). Todos esses mecanismos que orquestram a estruturação do texto levam a perceber efeitos de sentido essenciais, revelam as intersecções entre os vários elementos que se entrecruzam e fazem com que ele se apresente naquela maneira determinada.

Vimos que a construção do sentido independe, em si, dos elementos exteriores ao texto. O que se considera essencial é, ao contrário, a relação que, por meio do texto, se estabelece entre enunciador e enunciatário. A propósito disso, tiveram um papel importante nas atividades didáticas e nas aulas as reflexões a respeito do contrato fiduciário entre enunciador e enunciatário (ou co-enunciador), que levam a observar nos textos o fazer persuasivo e o fazer interpretativo e a problematizar a contraposição entre o verdadeiro e o veridictório, o real ontológico e a realidade do texto.

Introduzia-se assim o conceito de veridicção, isto é, de uma "verdade" dada pelos jogos da linguagem instalados no interior do texto, que se apreende estudando e analisando as combinações entre o parecer e o ser e suas negações ${ }^{77}$. Como escrevem Greimas e Courtés: "Não mais se imagina que o enunciador produza discursos verdadeiros, mas discursos que produzem um efeito de sentido "verdade"” (s/d: 487).

\footnotetext{
${ }^{77}$ Cf. nota 20 do presente trabalho.
} 
Ilustramos aqui alguns dos elementos essenciais que foram levados em conta na elaboração das atividades didáticas, por meio das quais procuramos construir um percurso que permitisse aos alunos alcançar uma autonomia de análise cada vez maior, podendo, de posse de ferramentas teóricas mais articuladas, refinar sua capacidade de descrição e interpretação dos elementos contidos no texto e aproximar-se dele preocupados não só com o que diz, mas com a maneira como diz.

Com efeito, partimos do pressuposto de que a sensibilidade na leitura de um texto não é um dom inato, mas uma capacidade que pode ser adquirida e que é fundamental não só na formação de um bom leitor, mas também de um bom produtor de textos na língua materna e na língua estrangeira. Assim, a interpretação de um texto (literário) não é epifânica e intuitiva, mas fruto de um trabalho minucioso e do hábito de "procurar" o sentido nas palavras, na "gramática" e na maneira em que os textos são construídos.

Temos observado que ao pedir aos discentes que analisassem um texto literário sem darlhes indicações ou mesmo sem que eles tivessem interiorizado determinados mecanismos de análise, raramente eles iam além de uma repetição parafrástica dos enunciados ${ }^{78}$, pois os alunos não possuem geralmente instrumentos e prática suficientes para iniciar uma leitura individual e o professor também não dispõe de material pedagógico que lhe permita criar estratégias a partir das quais se possa estimular uma leitura criadora de sentido.

\footnotetext{
${ }^{78}$ Chegamos a essa conclusão após ter realizado trabalhos com textos literários em classes nas quais os alunos eram chamados a analisar textos sem receber indicações específicas. Cf. a respeito também MAURAND/NAUDE (1987: 40) que referem de casos parecidos.
} 
O instrumental de análise da teoria semiótica possibilita realizar justamente esse tipo de conexão: fornece a docentes e discentes caminhos de análise e, dirigindo a atenção para as estruturas que organizam os textos e para os aspectos lingüísticos que as manifestam, permite que se obtenham interpretações, que se reflita sobre efeitos de sentido, que se leia o texto em profundidade.

AS FASES DO TRABALHO EM SALA DE AULA

Passemos agora à descrição da execução das atividades em sala de aula, onde os alunos liam, ouviam, falavam e escreviam a língua estrangeira, isto é, eram chamados a "fazer (com a) língua", realizando movimentos tanto na recepção, quanto na produção, enquanto observavam os textos e procuravam identificar os mecanismos de construção e as estruturas organizadoras que contribuem para a criação do sentido e do próprio texto visto como "aquilo que a leitura atualiza e o que a análise constrói” (BERTRAND, 2003: 55).

Embora algumas das atividades fossem realizadas individualmente, o trabalho em sala de aula acontecia principalmente em duplas ou pequenos grupos, pois isso, além de favorecer a interação e, portanto, o componente "social” do processo de aquisição/aprendizagem, propicia uma "negociação" entre os participantes da atividade (cf. WILLIS, 1996: 13-14). De fato, todas as fases da "tarefa" requeriam que as idéias fossem comparadas e que as opiniões de cada um fossem defendidas, antes de chegar a um resultado compartilhado pela dupla ou pelo grupo, que pudesse depois ser apresentado ao resto da classe para ser discutido por todos. 
Nesse momento os aprendizes podiam, portanto, simultaneamente pôr à prova tanto as argumentações que sustentavam sua leitura do texto, quanto as habilidades lingüísticas, pois deviam tanto compreender as manifestações dos outros membros do grupo, quanto se fazer compreender pelos outros.

A organização em grupos era essencial também porque permitia que cada aluno tivesse mais espaço para expor suas idéias, pois na classe é mais difícil que todos tomem a palavra. Além disso, no trabalho em grupo há um "tempo de planejamento" (planning time) para a preparação da atividade, definido em conjunto entre todos os participantes, que contribui para melhorar o nível da performance (SKEHAN/FOSTER, 2001; ELLIS/YUAN, 2004), além de diminuir a ansiedade $^{79}$, pois num grupo pequeno e sem ainda a necessidade de se expor a toda a classe e ao professor, os alunos podiam concentrar-se no desenvolvimento da "tarefa" com maior tranqüilidade e chegar mais "seguros" ao momento do debate por ter já comparado suas idéias com um ou mais colegas.

Numa estruturação da aula desse tipo, não há um professor que ocupa o centro e irradia o saber. Os grupos de alunos constituem o elemento principal e eles não só trocam informações no interior do próprio grupo criando movimentos construtivos, mas também transmitem essas informações para os outros e recebem-nas deles, dando vida a produtivas trocas de idéias. Da monodirecionalidade das aulas tradicionais com o professor como única fonte de conhecimento, passa-se assim à multiplicação dos fluxos comunicativos que aumentam a densidade de

\footnotetext{
${ }^{79}$ Reduzir a ansiedade e estimular a autoconfiança e a motivação pode, segundo a hipótese do filtro afetivo, propiciar a aquisição da língua estrangeira. De fato, o filtro afetivo seria uma espécie de bloqueio que impediria a "entrada" de novos conhecimentos. A hipótese foi difundida por Krashen (1982: 30-32) a partir da proposta de Dulay e Burt (1977) e é desde então amplamente aceita pelos estudiosos da área.
} 
informação dentro da classe e dão a todos a possibilidade de ser tanto emissores quanto receptores de língua ${ }^{80}$.

O papel do professor é o de "mediador", que procura estimular a participação de todos, e de “orientador", pronto a fornecer suporte quando necessário. A posição do aprendiz é sempre participativa, ativa e construtiva: ele toma a palavra, pode falar em primeira pessoa e ter espaço para expor suas idéias, pode dizer "é isso para mim" (BARTHES, 1974: 48), afirmando sua posição individual e confirmando sua própria leitura e interpretação do texto. Assim, o conhecimento constrói-se a partir da contribuição de cada um, que é discutida em grupo com a orientação do professor, sem a necessidade de chegar a uma única interpretação válida para todos, mas, ao contrário, admitindo várias leituras.

Para o percurso realizado em sala de aula e, em especial, para as atividades com os seis textos escolhidos para fazer parte do presente trabalho, foi elaborada a seqüência que esquematizamos na página seguinte. Na tabela indicamos cada um dos momentos da "tarefa", os objetivos que nos propusemos para as diversas fases do trabalho e as habilidades lingüísticas que os alunos precisavam utilizar para a realização de cada parte da "tarefa":

\footnotetext{
${ }^{80}$ Cf. Vedovelli (2002: 119-126).
} 


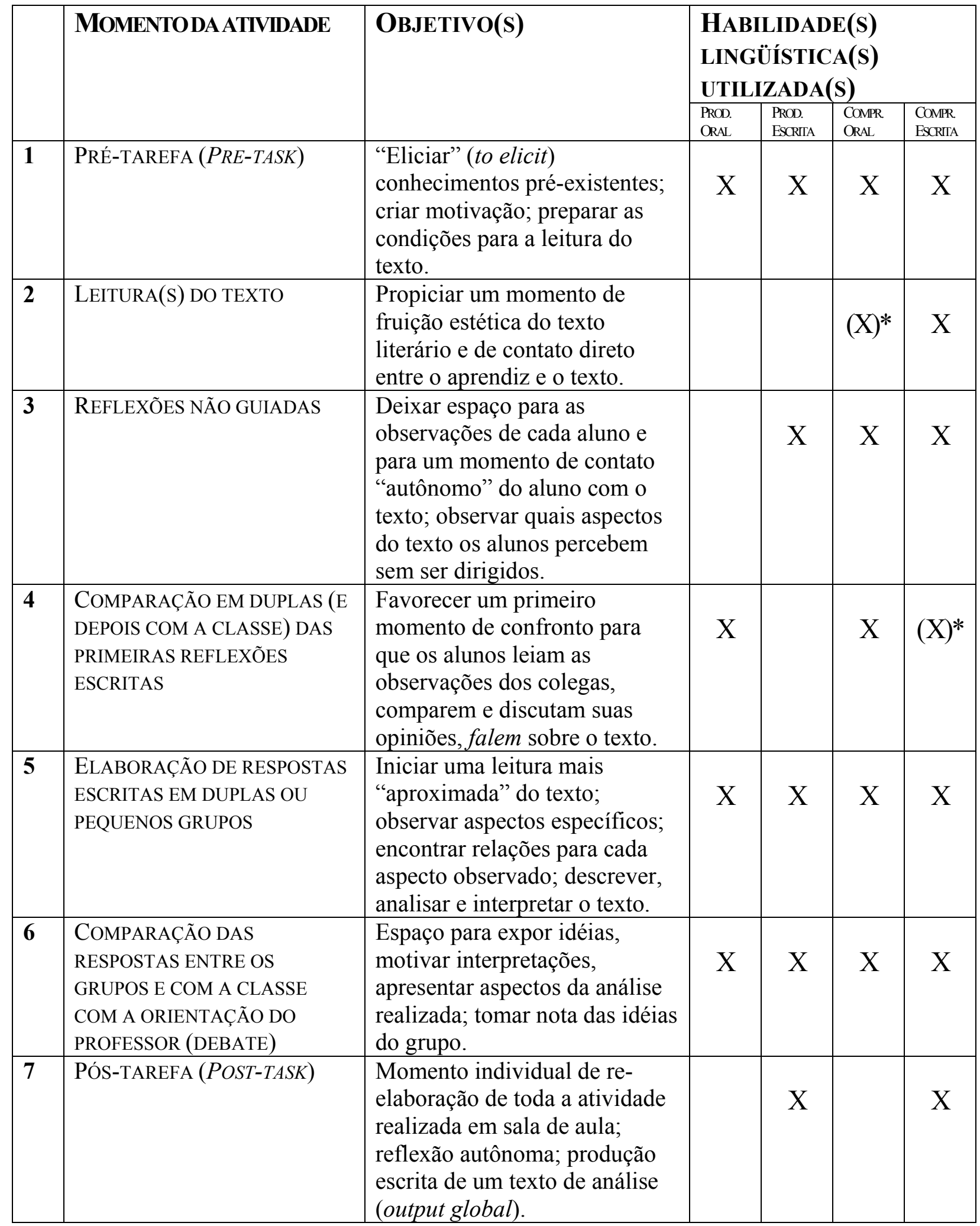

* Os parênteses indicam que a habilidade era incluída eventualmente e não necessariamente. 
Vejamos agora com mais detalhes as características de cada uma das etapas do percurso de análise realizado em sala de aula:

(1) PRÉ-TAREFA

A primeira etapa, que chamamos "pré-tarefa" (pre-task), é o conjunto de atividades que antecede o trabalho com o texto literário em si. Foram, em geral, momentos de "eliciação" conhecimentos pré-existentes relativos a aspectos ligados de algum modo ao próprio texto, que preparavam tanto para a leitura quanto para o desenvolvimento da "tarefa".

"Eliciar" (do inglês to elicit) significa nesse contexto "trazer à tona", "fazer aflorar", “evocar”, mas também conduzir alguém para que chegue pela lógica a alguma conclusão, faça inferências, utilize um elemento do presente para "chamar" - e poder depois utilizar conhecimentos de outra maneira não imediatamente "acessíveis".

O primeiro objetivo desse tipo de atividade é o de criar "motivação" no aluno para a leitura do texto e para a execução da atividade prevista.

O termo "motivação", embora amplamente utilizado nos estudos sobre ensino/aprendizagem de línguas estrangeiras, não é de tão simples definição. No nosso entendimento e para as finalidades que nos propomos aqui, "motivação" diz respeito à direção e à magnitude de um determinado comportamento (cf. DÖRNYEI, 2001: 7-17). Isso significa que dizendo "motivação" fazemos referência a situações que levam os aprendizes a "querer fazer" algo, a ter persistência nesse "fazer" e a mostrar "empenho" em sua realização. 
A "pré-tarefa" serve, então, para estimular o desejo de saber e a curiosidade e, portanto, para suscitar o interesse dos alunos em relação ao texto. Essa não é, contudo, sua única finalidade. A atividade ajuda também a preparar um campo comum a toda a classe, isto é, a estabelecer um repertório de conhecimentos prévios compartilhados, com o qual todos possam contar na hora da leitura e da interpretação do texto.

Além disso, o momento da "pré-tarefa" pode também "eliciar", isto é, trazer para o aqui e agora, conhecimentos lingüísticos específicos que podem ser utilizados no desenvolvimento da "tarefa". Pode tratar-se de estruturas lingüísticas presentes no texto e que os aprendizes podem entender com mais competência após uma (re)utilização ou então de elementos lingüísticos que podem ser usados na exposição das próprias interpretações relativas ao texto.

Para "introduzir" o texto literário foram escolhidas atividades de diferente natureza, como, por exemplo, a análise de elementos pré-textuais, entre os quais a capa do livro do qual haviam sido extraídos os textos ${ }^{81}$ ou o título do próprio conto ou poema que seria analisado. Nesse caso o intuito foi reconstruir um possível movimento da "vida real", na qual, antes de ler um conto, um romance ou um poema, freqüentemente paramos para observar a capa do livro e os elementos que ela contém ou então refletimos sobre o título do texto que estamos prestes a ler.

No caso da capa do livro foi aproveitado o sincretismo entre verbal e não verbal nela contido e foram analisados, antes em pequenos grupos e depois com toda a classe, os elementos

\footnotetext{
${ }^{81}$ Para introduzir o conto do primeiro semestre foi utilizada, por exemplo, a capa do livro reproduzida na página 46 deste trabalho.
} 
presentes, sendo que os alunos foram incentivados a fazer previsões sobre o conto que leriam a partir dos indícios observados e dos efeitos de sentido identificados.

Em alguns casos foram realizadas leituras que antecipavam o tema tratado pelo texto ou atividades de grupo a partir de material preparado pelo professor, cujo objetivo era uma reflexão prévia sobre assuntos que seriam trazidos pelo texto.

Com o objetivo de "gerar" e coletar idéias na classe, foi também proposto às vezes o dito brainstorming, uma atividade de grupo durante a qual, a partir de um determinado conceito, de uma imagem ou de uma frase (no nosso caso, por exemplo, o título de um dos textos), todos os participantes podem expor suas "associações", que são escritas e projetadas para tornar-se "disponíveis" para todos.

Essa atividade foi proposta, por exemplo, antes da leitura do poema La poesia oggi, analisado no sexto semestre, cujo título foi utilizado para que os discentes pudessem refletir sobre “o que é" e "onde está" a poesia hoje e trazer para o presente da sala de aula idéias sobre esse tema, de modo que, depois disso, se pudessem confrontar as opiniões vindas da classe com as contidas no poema.

(2) $\operatorname{LEITURA}(S)$ DO TEXTO

A fase da(s) primeira(s) leitura(s) do texto foi concebida como momento de fruição estética e previa sempre uma leitura silenciosa individual, que podia ser seguida por outras leituras em 
voz alta ou por gravações. Sempre que possível o texto era projetado para que na sala a atenção de todos fosse dirigida às palavras do texto e a como eram dispostas graficamente, de modo que o olhar deslizasse por elas e os sons ecoassem, deixando acontecer a "emoção estética", que Greimas define como a fusão de sujeito e objeto (cf. 1987: 99), que rompe com o cotidiano e se configura como evento extraordinário.

Durante essa fase ainda é difícil perceber a complexidade que os textos literários “escondem” e, no entanto, ela é indispensável, porque é a mais descomprometida e desinteressada, assim, garante o contato prazeroso com o texto literário, permitindo intuições iniciais, que, embora possam ser confirmadas ou não, constituem um primeiro importante passo em direção a sua análise e interpretação.

Esse momento dedicado ao "prazer do texto" é também essencial para que seja confirmada a motivação, para que o "querer saber" seja estimulado pelo contato direto dos alunos com os textos poéticos, que, longe de trazer para a sala de aula de língua estrangeira situações fictícias e artificiais, evocam de "verdade" e criam ligações a partir das quais se prepara o terreno para o desenvolvimento do conhecimento.

\section{(3) REFLEXÕES NÃO GUIADAS}

Após a(s) leitura(s), o percurso previa um momento individual de produção escrita, que levava a um retorno ao texto e a uma nova leitura (ou mais que uma). Pedia-se aos discentes que 
escrevessem suas primeiras "intuições" sobre o texto em italiano, transferindo para o papel suas idéias sem nenhuma restrição.

De fato, nesse momento era permitido qualquer tipo de observação sobre qualquer um dos aspectos do texto que tivesse chamado a atenção do aluno, numa fase ainda muito incipiente do contato com o texto. Acontecia que às vezes as anotações diziam respeito ao aspecto gráfico, às vezes a uma determinada palavra que se repetia em posições estratégicas, outras vezes a sons recorrentes, outras vezes ainda a uma ligação entre o título e um trecho do texto, só para citar alguns exemplos.

Essa fase do trabalho tinha o objetivo de permitir um primeiro contato "global" com o texto, antes de iniciar uma análise que ia depois cada vez mais em direção ao "detalhe", seguindo um movimento do global ao analítico, da percepção geral ao particular. Ademais, era útil observar quais elementos os alunos percebiam sem ser dirigidos e para onde ia “espontaneamente” sua atenção.

Vale a pena ressaltar que com o passar dos semestres essa atividade revelou-se mais bemsucedida e proveitosa. Isso pareceu-nos um sinal de que, possuindo mais ferramentas de análise e tendo se apropriado de um determinado repertório de "instrumentos operativos", os alunos conseguiam ter, desde o começo, intuições produtivas sobre o texto e estavam preparados a confirmá-las ou desmenti-las nas leituras posteriores e na troca de idéias com o grupo. 
(4) COMPARAÇÃO EM DUPLAS OU PEQUENOS GRUPOS (E DEPOIS COM A CLASSE) DAS PRIMEIRAS OBSERVAÇÕES ESCRITAS

Em seguida, cada aluno comparava suas anotações com as anotações de um ou dois colegas. Esse momento da atividade proporcionava uma primeira ocasião de confronto entre os discentes que podiam, assim, dar início a um movimento de troca na interpretação do texto. De fato, eram lidas e/ou ouvidas as observações de outros e, a partir delas, nasciam intercâmbios, de modo que cada um pudesse compartilhar com o(s) outro(s) como havia chegado a determinadas "conjecturas".

A mesma coisa podia ser repetida com outros colegas para que todos pudessem ter acesso a percepções diferentes sobre o mesmo texto e já iniciar a traçar hipóteses de leitura e a refletir sobre o sentido de aspectos do texto problematizados por eles mesmos ou pelos colegas.

Tudo isso acontecia sempre em italiano, inclusive porque, após a comparação em duplas ou pequenos grupos, essa primeira "experimentação de idéias" que cada aluno fazia com os colegas explicando o que havia observado ou por que acreditava num determinado caminho de leitura era compartilhada com o resto da classe e realizava-se o primeiro momento coletivo para expor as conclusões resultantes da comparação.

Todos podiam tomar a palavra, sugerir reflexões, explicitar como e por que enxergavam no texto a presença de determinadas leituras, criando assim na sala uma movimentação de idéias e preparando-se para a próxima fase. 


\section{(5) ELABORAÇÃO DE RESPOSTAS ESCRITAS EM DUPLAS OU PEQUENOS GRUPOS}

Ao primeiro momento individual em que cada aluno produzia livremente e por escrito uma primeira "reação" ao texto literário, seguia a análise dirigida pelas perguntas e pelas atividades propostas, que constituía o momento central do trabalho.

Como dissemos, as atividades foram elaboradas com o objetivo de servir como "guia" e de dirigir a atenção numa sorte de "focalização seletiva", no sentido de fazer com que os alunos refletissem em cada momento sobre um aspecto diferente do texto, sempre se perguntando quais eram os efeitos de sentido das escolhas do enunciador. Isso sugeria percursos de leitura possíveis e indicava como a língua no texto pode ser olhada com mais atenção para, a partir disso, desenvolver interpretações, descobrir construções no texto e elucidar mecanismos da língua e do discurso.

Para realizar essas atividades, os alunos deviam novamente voltar ao texto, lê-lo mais vezes e aprofundar-se nos aspectos menos evidentes. De fato, só debruçando-nos sobre os textos, podemos perceber relações realmente significativas e ler nos interstícios e só entregando-nos a uma leitura minuciosa, podemos conseguir chegar aos aspectos não imediatamente evidentes. Essa é, aliás, uma das características dos textos literários: eles podem ser relidos inúmeras vezes e, todas as vezes, revelam detalhes que antes não haviam sido notados.

Os alunos aprendem assim a reconhecer que na língua há indícios e associações, muitas vezes inesperados, que permitem descobrir sentidos e construir uma vivência profunda com a 
língua e com o texto, na qual conhecer a "regra" não tem valor em si, mas pelas relações que, a partir da "regra" e de suas subversões, é possível perceber.

Essa fase do trabalho também visava a manter viva a motivação, porque os alunos experimentavam o prazer da descoberta, o prazer de revelar, a si mesmos e aos outros, aqueles detalhes que, "escondidos" no início, acabavam manifestando sentidos insuspeitados.

Os aprendizes trabalhavam alternadamente em duplas ou pequenos grupos, resolvendo cada uma das questões que constituíam as atividades. Havia sempre nessa fase a leitura conjunta (compreensão escrita), realizada agora com um objetivo específico que mudava a cada pergunta e que levava à negociação oral e à interação entre os discentes (compreensão e produção oral), estimulando sua atenção, pois o grupo devia chegar a um único resultado escrito (produção escrita) que depois seria lido a todos e discutido com a classe e com o professor (compreensão e produção oral).

(6) COMPARAÇÃO DAS RESPOSTAS ENTRE OS GRUPOS E COM A CLASSE COM A ORIENTAÇÃO DO PROFESSOR

Terminada a elaboração de respostas escritas por parte das duplas ou dos grupos, procediase à comparação dos "resultados". Essa fase era realizada simultaneamente com toda a classe, enquanto o professor, por um lado, "coordenava" o trabalho e, por outro, incentivava a participação dos alunos. 
As idéias de todos eram ouvidas dando-se início ao debate num movimento que previa a instauração de mecanismos de argumentação para a defesa das convicções de cada grupo. O trabalho assim estruturado permitia, portanto, a participação de todos e uma produtiva troca de opiniões, em que tanto a "língua", quanto as propostas "vinham" dos alunos que, a partir das indicações dadas, construíam suas análises e interpretações, sempre buscando no texto a confirmação de suas hipóteses.

O papel do professor não era, assim, o de ter ou o de fornecer respostas prontas, mas o de debater com os alunos para que eles chegassem a suas conclusões, eventualmente mostrando como poderiam encontrar nos textos elementos que confirmavam ou desmentiam suas afirmações. Também não cabia ao professor decretar o "certo" e o "errado": sua função era, ao contrário, a de "orientar" deixando espaço para que os estudantes pudessem manifestar suas idéias, trabalhando com o "prazer" de descobrir os mecanismos de construção dos textos que permitem reconstruir o sentido e as maneiras como se dá.

De fato, as respostas eram sempre abertas e comportavam mais do que uma única "solução". Tudo o que se afirmava devia, porém, responder aos princípios da pertinência e da produtividade $^{82}$ e na complexa tarefa que é a análise de um texto literário (ainda mais se realizada em língua estrangeira e a partir de um texto escrito nessa mesma língua) a função do professor era a de ajudar os alunos a acostumar-se com o "rigor" e com a disciplina, que são próprios da atividade de análise.

\footnotetext{
${ }^{82}$ A formulação é de Andrea G. Lombardi (c.p.), com o qual muito refleti sobre textos, leitura e literatura. Essas reflexões foram uma contribuição decisiva no desenvolvimento do curso e das aulas que estamos descrevendo aqui.
} 
Isso significa que uma interpretação e uma idéia sobre o texto que está sendo analisado são aceitáveis e válidas, isto é, são pertinentes, só quando podem ser fundamentadas no próprio texto e nas relações nele contidas; e são produtivas, quando ajudam a enxergar possíveis campos de interpretação, às vezes não imediatamente visíveis e, contudo, presentes.

Para esclarecer qual era a postura que nos guiava no trabalho, tomamos emprestada uma afirmação de Umberto Eco, irônica, no estilo que o caracteriza, e ao mesmo tempo de grande clareza:

O leitor é livre de ousar todas as interpretações que quer, mas é, não obstante, obrigado a refrear-se cada vez que o texto deixa de aprovar suas elucubrações, um tanto quanto libidinais ${ }^{83}$.

Era esse o espírito que conduzia as aulas e nesse espírito todos eram levados a manifestarse e a debater na classe suas idéias.

As fases (5) e (6) eram repetidas várias vezes ao longo do ciclo de aulas em que se analisava o mesmo texto literário, pois as atividades previstas para aquele texto eram segmentadas conforme o tempo disponível e a ligação temática existente entre as questões.

A escolha derivava também da necessidade de criar etapas intermediárias, de mudar a configuração do grupo e da classe em geral, que, dessa maneira, não permanecia na mesma "posição" por muito tempo: dos pequenos grupos passava-se à classe inteira e depois a outros

\footnotetext{
83 "Le lecteur est libre de hasarder toutes les interprétations qu'il veut, mais néanmoins obligé de se réfréner chaque fois que le texte cesse d'approuver ses par trop libidinales élucubrations." (ECO, 1987: 23).
} 
grupos ou duplas e mais tarde de novo à classe, para que se pudesse propiciar uma multiplicação na troca de idéias e explorar as potencialidades da classe.

\section{(7) PÓS-TAREFA}

Uma vez encerrado o trabalho em classe ${ }^{84}$, chegava-se à fase conclusiva - a ser realizada fora da sala de aula - que consistia na elaboração de um texto escrito de análise por parte de cada um dos discentes. Denominamos essa fase "pós-tarefa", a partir do inglês post-task, pois era desenvolvida num momento posterior à "tarefa" em si, com o objetivo de re-elaborar o material e as hipóteses interpretativas sobre os textos literários que haviam surgido durante as aulas.

Nessa produção escrita final (que chamamos output global) eram retomadas e retrabalhadas tanto as respostas escritas pelos grupos para cada uma das perguntas da atividade, quanto as idéias anotadas durante os debates em sala de aula (o output parcial relativo a aspectos específicos do texto), mas não se esperava, que os alunos "reproduzissem" o que havia sido discutido na sala de aula, mesmo porque muitas vezes não se chegava a uma única conclusão, visto que várias interpretações eram plausíveis e aceitáveis e cabia a cada "leitor" escolher aquelas que compartilhava. Além disso, uma nova leitura do texto realizada individualmente, após as aulas, podia também acrescentar reflexões que, mesmo não discutidas com o grupo, podiam fazer parte da análise escrita individual.

\footnotetext{
${ }^{84}$ Cada aula durava entre 90 e 100 minutos (90 no noturno e 100 no matutino) e para a análise de um texto literário eram necessários de quatro a seis encontros.
} 
A indicação dada aos discentes para a execução da "pós-tarefa" era que redigissem sua própria análise do texto literário, utilizando as atividades desenvolvidas em sala de aula como roteiro de base.

A idéia era que os alunos (re)utilizariam nessa fase do trabalho o "repertório" de conhecimentos adquirido durante as aulas dedicadas àquele texto, isto é, as reflexões feitas e os argumentos preparados em grupo para responder às questões e debater com os colegas. Junto com isso, obviamente, a "língua" lida, ouvida, falada e escrita durante as aulas que serviria nesse momento para a redação do trabalho escrito.

De qualquer maneira, o objetivo era estimular a liberdade de leitura, deixar espaço para que em sua própria redação cada aluno tivesse a possibilidade de "tomar a palavra" - desta vez por escrito e individualmente - ainda mais livremente do que na sala de aula, escrevendo também aquilo que durante as aulas não havia tido ocasião de dizer e podendo desenvolver sua interpretação pessoal do texto em direção a uma autonomia cada vez maior.

Cabe ressaltar, porém, que para a produção escrita valiam os mesmos critérios de pertinência e produtividade utilizados nas aulas, ou seja, que as afirmações sobre o texto precisavam ser justificadas, motivadas e baseadas em elementos contidos no próprio texto, além de procurar levar em conta aspectos do texto relevantes para a análise.

Nossa convicção é que, analisando textos literários e refletindo sobre o alcance e as múltiplas interpretações da linguagem na literatura, a língua estrangeira é aprendida como língua em uso e em movimento e vai construindo-se no aprendiz como forma que dá indícios e pistas 
para chegar ao sentido, como gramática que é significado e transformação, como regra que precisa ser observada e analisada no texto para que possa ser apreendida e para que possam também ser entendidas suas subversões.

De fato, o objetivo último é formar leitores e produtores de textos competentes, que saibam ler, analisar e entender textos literários, mas também qualquer tipo de texto em língua estrangeira. Para esses alunos as aulas deviam servir para ganhar cada vez mais autonomia e consciência das possibilidades de leitura e a produção escrita individual devia ser um momento para “experimentar" simultaneamente a análise do texto e a língua estrangeira.

No próximo capítulo examinaremos essas redações - escritas como análise dos seis textos literários escolhidos para este trabalho - e procuraremos perceber como os alunos utilizaram a língua estrangeira, como se manifestou sua capacidade de análise, se e como houve um desenvolvimento e que tipo de recorrências e características é possível observar. 


\section{A AVALIAÇÃO DAS PRODUÇõES ESCRITAS DOS APRENDIZES}

Neste capítulo serão mostrados e comentados os resultados de nosso estudo longitudinal, referentes aos três anos do curso experimental que ministramos. Como já foi dito no início deste trabalho, o currículo, que integrava o ensino da língua italiana e a análise de textos literários, foi implementado nas disciplinas de graduação de Língua Italiana do curso de Letras da Universidade de São Paulo, em duas turmas (matutino e noturno) que começaram sua habilitação em Língua e Literatura Italiana no primeiro semestre de 2004 e concluíram as disciplinas de Língua Italiana no segundo semestre de 2006.

Os textos de análise produzidos pelos alunos são relativos aos três contos e aos três poemas escolhidos para fazer parte desta tese. Os trabalhos dos discentes foram escritos ao longo dos seis semestres de curso, sendo que a primeira redação foi elaborada nas semanas iniciais do primeiro semestre, a sexta foi a última antes das provas de final de curso e as outras quatro foram realizadas entre o segundo e o quinto semestre, uma por semestre, nas mesmas turmas e após ter desenvolvido em sala de aula atividades didáticas, tal como as descrevemos no capítulo anterior.

Os dados que resultam da avaliação de redações assim distribuídas ao longo do percurso podem ser considerados significativos para entender o desenvolvimento dos aprendizes, pois, além de mostrar qual era a situação no começo e no fim do curso, levam em conta também quatro momentos intermediários, importantes para evitar que a observação se concentre no nível de proficiência alcançado pelos alunos e para permitir que a atenção seja dirigida ao que “aconteceu" ao longo do processo de aprendizagem. 
De fato, nosso interesse maior esteve na busca de indícios que permitissem entender se houve uma evolução na aquisição tanto das competências lingüísticas, quanto da competência discursiva e, em caso afirmativo, observar características que pudessem revelar aspectos de como o processo ocorreu.

Para alcançar esse objetivo, foram aleatoriamente escolhidos dez alunos, em parte pertencentes à turma do curso matutino e em parte à do noturno, que iniciaram a habilitação em Língua e Literatura Italiana sem nenhum conhecimento prévio da língua.

Para identificar os alunos serão utilizadas aqui as letras de $\mathrm{A}$ a $\mathrm{J}$ e para cada aluno serão levadas em consideração seis redações discriminadas com números de 1 a 6 , correspondentes ao semestre em que foi realizado o trabalho e sempre precedidos pela letra atribuída ao aprendizautor. Teremos, portanto, para o aluno A as redações A1, A2, A3, A4, A5 e A6, para o aluno B as redações B1, B2, B3, B4, B5 e B6, e assim por diante, para todos os outros alunos e para todas as outras produções escritas.

Durante os três anos de habilitação os alunos selecionados não freqüentaram outros cursos de italiano, com exceção de dois (os alunos $\mathrm{F} \mathrm{e}^{85}$ ), que apenas no semestre inicial participaram do primeiro nível do curso de extensão de italiano organizado pela própria Área de Língua e Literatura Italiana da USP (o chamado Italiano no Campus $^{86}$ ). O aluno F declarou ter desistido

\footnotetext{
${ }^{85}$ Há entre os selecionados para participar da pesquisa tanto alunos quanto alunas. No entanto, após termos excluído os nomes e atribuído letras do alfabeto, eles se tornaram "anônimos". Usaremos aqui, portanto, sempre o masculino. ${ }^{86}$ Os cursos de língua e cultura italiana do Italiano no Campus são abertos à comunidade e recebem um público variado. São ministrados por graduados em Letras que possuem um vínculo com a Faculdade de Filosofia, Letras e
} 
desse curso de extensão antes do final e, portanto, só o aluno J freqüentou-o até o fim, mas, como dissemos, não continuou nos semestres seguintes $^{87}$. Nossa previsão foi que essa limitada experiência, ademais concentrada na primeira fase do processo de aprendizagem, não produziria mudanças significativas e isso foi confirmado pelos dados.

De fato, embora saibamos que existem diferenças individuais na aquisição/aprendizagem de uma língua estrangeira e que cada aluno possui um estilo cognitivo distinto, procuramos reduzir ao mínimo as variações tanto nas condições de partida dos discentes, quanto nos estímulos advindos de outros cursos com instruções explícitas. Foi por isso que procuramos os alunos para a pesquisa entre os que limitaram seu contato com a língua e a literatura italiana pelo menos no que diz respeito ao contexto de instrução formal - às disciplinas de sua habilitação, de modo que os dados colhidos pudessem dar indicações mais confiáveis e comparáveis sobre a relação entre o nosso curso experimental e os resultados da análise das produções escritas.

Quanto às disciplinas previstas para a habilitação em Língua e Literatura Italiana, vale lembrar que no período de 2004 a 2006 eram as seguintes:

Ciências Humanas por serem alunos de pós-graduação e, às vezes, de licenciatura e são organizados e coordenados por professores da Área de Língua e Literatura Italiana. Cabe aos professores orientar a prática pedagógica dos alunos ministrantes e as pesquisas ligadas aos cursos.

${ }^{87}$ Os dados sobre os alunos citados até agora e os que serão ainda ilustrados a seguir nos foram fornecidos pelos interessados por meio de um questionário. 


\begin{tabular}{|l|l|l|}
\hline SEMESTRE & $\begin{array}{l}\text { DISCIPLINAS DE } \\
\text { LíNGUA ITALIANA }\end{array}$ & $\begin{array}{l}\text { DISCIPLINAS DE } \\
\text { LITERATURA ITALIANA }\end{array}$ \\
\hline $1^{\circ}$ & LÍNGUA ITALIANA I (4H) & LITERATURA ITALIANA I (2H) \\
\hline $2^{\circ}$ & LÍNGUA ITALIANA II (4H) & LITERATURA ITALIANA II (2H) \\
\hline $3^{\circ}$ & LÍNGUA ITALIANA III (4H) & LITERATURA ITALIANA III (4H) \\
\hline $4^{\circ}$ & LÍNGUA ITALIANA IV (4H) & LITERATURA ITALIANA IV (4H) \\
\hline $5^{\circ}$ & LÍNGUA ITALIANA V (4+2H) & $\begin{array}{l}\text { LITERATURA ITALIANA V (6H) + } \\
\text { HISTÓRIA E CRÍTICA DA LITERATURA ITALIANA I } \quad \mathbf{( 2 H )}\end{array}$ \\
\hline $6^{\circ}$ & LÍNGUA ITALIANA VI (4+2H) & $\begin{array}{l}\text { LITERATURA ITALIANA VI (6H) + } \\
\text { HISTÓRIA E CRÍTICA DA LITERATURA ITALIANA II } \quad \mathbf{( 2 H )}\end{array}$ \\
\hline
\end{tabular}

Os dez alunos, cujos textos foram analisados para esta pesquisa, freqüentaram todas as disciplinas de Língua Italiana previstas, isto é, o nosso curso experimental. É preciso dizer que esse curso teve ao longo dos seis semestres sempre 4 horas semanais, pois as duas horas suplementares do quinto e do sexto semestre foram dedicadas à prática escrita e foram ministradas por um outro professor (o mesmo no curso matutino e noturno).

Todos os alunos selecionados para a pesquisa freqüentaram também as disciplinas de Literatura Italiana de I a IV. Entretanto, para estas últimas houve variações, pois nem todos os discentes as cursaram com o mesmo professor e no mesmo semestre. A disciplina "Literatura Italiana V" não foi freqüentada pelos alunos A, F, H e I; os mesmos - com exceção de $\mathrm{H}$ também não cursaram "Literatura Italiana VI". Outro dado a acrescentar é que, dos dez discentes, quatro não freqüentaram as duas disciplinas obrigatórias do quinto e do sexto semestre "História e Crítica da Literatura Italiana I e II" (alunos A, D, F e I). 
Para os fins que esta pesquisa se propõe importa ainda ressaltar que as disciplinas de Literatura Italiana, embora utilizassem sempre textos de estudo em italiano (às vezes com o auxílio de traduções em português), nem sempre foram ministradas na língua estrangeira da habilitação. Conforme afirmaram os próprios alunos, na maior parte dos casos, principalmente nos três primeiros semestres, utilizavam-se nessas disciplinas tanto o italiano quanto o português ou somente o português. A partir do quarto semestre reduziu-se o uso do português e deu-se cada vez mais espaço ao italiano, que nos últimos semestres foi a única língua das atividades desenvolvidas em sala de aula. As monografias, as provas e os outros trabalhos escritos podiam, contudo, ser realizados até o último semestre tanto em italiano quanto em português, sendo que a maior parte dos discentes os redigiu em português até o final do curso. A conseqüência disso é que os únicos trabalhos escritos em italiano por esses alunos eram aqueles redigidos nas disciplinas de Língua Italiana, entre os quais estão as produções que analisaremos aqui.

No que concerne às disciplinas da habilitação, um último detalhe a ser mencionado para que o quadro seja completo é que os dez alunos freqüentaram, em alguns raros casos, disciplinas optativas da Área de Língua e Literatura Italiana. Em especial, o aluno J cursou "Cultura e Sociedade da Itália Contemporânea I" e os alunos B, C e F freqüentaram "Cultura e Sociedade da Itália Contemporânea II" (ambas ministradas em italiano). O aluno J incluiu no currículo também a disciplina optativa "Tradução comentada do Italiano I".

Tudo isso significa que, na própria habilitação, o percurso dos discentes não foi absolutamente idêntico. $O$ único dado certo é que todos iniciaram e terminaram contemporaneamente e freqüentando o mesmo curso apenas as disciplinas de Língua Italiana, 
pois, como vimos, mesmo para as disciplinas de Literatura Italiana de I a IV - cursadas por todos os alunos participantes da pesquisa - as condições não foram exatamente as mesmas.

Dissemos que no exame das redações elaboradas por esses alunos a partir das atividades desenvolvidas em sala de aula sobre cada um dos seis textos literários selecionados, nossos principais objetivos visaram a verificar "tendências" tanto do ponto de vista da progressão mais estritamente lingüística, quanto de uma perspectiva mais ligada ao desenvolvimento da capacidade de análise.

Procuramos, portanto, por um lado, índices quantitativos que permitissem verificar o nível de interlíngua alcançado pelos alunos em cada um dos seis semestres e, por outro, numa análise de tipo qualitativo, observamos como os textos de análises produzidos se modificaram ao longo dos semestres e em que direção se manifestaram variações sobretudo na competência discursiva, no sentido de saber reconhecer temas e figuras, as categorias de tempo, espaço e pessoa, os efeitos de sentido e as relações portadoras de sentido no interior dos textos, isto é, de saber analisar e interpretar textos literários.

Consideramos relevante acrescentar mais algumas reflexões sobre o que está aqui associado à competência discursiva. Em primeiro lugar, cabe sublinhar que, observando como a competência discursiva se manifesta nas produções escritas dos alunos, estamos sempre pressupondo também as competências lingüísticas, pois são necessárias tanto competências receptivas para "entender" o texto, quanto competências produtivas para poder escrever a redação de análise. 
Ademais, as competências interdiscursiva, textual e intertextual também são implicitamente verificadas, pois na análise de um texto literário o aluno deverá, por um lado, levar em conta a heterogeneidade constitutiva dos discursos e mostrar as competências cultural, intercultural e ideológica, bem como que é capaz de reconhecer e usar as estruturas de manifestação da língua, além de identificar as relações de um texto com os outros textos, que, estabelecendo diálogos, criam novos sentidos.

\subsection{AVALIAÇÃo Da COMPETÊNCIA LINGÜÍ́STICA}

Como já foi dito, para avaliar o desenvolvimento das competências dos discentes, foram considerados os momentos inicial e final, além de quatro momentos intermediários de seu processo de aprendizagem. Isso é particularmente importante para o exame do desenvolvimento da competência lingüística, pois permite "fotografar", em intervalos regulares (no nosso caso uma vez por semestre), a produção dos aprendizes ao longo do percurso de construção de sua interlíngua.

Cabe relembrar que, na definição que utilizamos aqui, a interlíngua é um sistema lingüístico com normas próprias e em contínua transformação, que da língua materna vai em direção à língua alvo $^{88}$. Em se modificando de forma não necessariamente linear, nem

\footnotetext{
${ }^{88}$ A questão do movimento da interlíngua em direção à língua alvo é, na realidade, muito mais complexa do que essa definição deixa transparecer, pois há ao menos dois motivos com base nos quais se pode prever que a língua alvo poderia não ser alcançada nunca: em primeiro lugar, na maior parte dos casos o aprendiz não percebe a necessidade de emular o falante nativo até a "perfeição", já que pode entender e ser entendido, mesmo num estágio em que sua interlíngua ainda não se desenvolveu para chegar a esse ponto; em segundo lugar, não há, na verdade, uma única língua a ser imitada e uma única língua alvo que pode ser alcançada, sendo que a língua como sistema estático e
} 
regularmente gradual (cf., entre outros, LARSEN-FREEMAN, 2006), o desenvolvimento da interlíngua fornece sinais e possibilita inferir características referentes ao processo de aprendizagem, além de permitir verificar se houve um "progresso" dos aprendizes, com base no qual podem ser feitas avaliações sobre o efeito de um determinado tipo de instrução formal (WOLFE-QUINTERO et al., 1998: 3).

Há muitas dimensões para verificar o desenvolvimento numa língua. Existe, contudo, um consenso de que os critérios de precisão ${ }^{89}$, fluência e complexidade (accuracy, fluency e complexity) são os mais confiáveis, pois possuem um status independente na performance em língua estrangeira, em que os aprendizes podem ter objetivos diferentes em momentos distintos (LARSEN-FrEemAN, 2006: 592; ver também SKEHAN, 1998 e RoBINSON, 2001).

Além disso, a maneira como a "tarefa" é executada influencia essas medidas de várias formas, o que possibilita observar o resultado dos alunos a partir de diferentes pontos de vista. Com efeito, subsistemas lingüísticos, dimensões de proficiência e até elementos particulares da língua interagem e podem ou suportar-se reciprocamente ou competir entre eles, provocando assim resultados sempre distintos. O que temos são, em suma, meios de comparação através dos quais se torna possível uma avaliação global, que não depende de uma habilidade específica ou de uma estrutura lingüística pré-determinada (cf. LARSEN-FREEMAN, 1983: 287).

homogêneo é uma ficção normativa (cf. KLEIN, 1998). Não obstante, as normas e a gramática da língua alvo continuam sendo a referência e a idéia de uma produção cada vez mais próxima dela (target-like output) é a que guia a avaliação dos aprendizes.

${ }^{89}$ A dúvida entre as palavras precisão e correção para traduzir o substantivo accuracy do inglês foi resolvida em favor da primeira opção por acharmos que ela está menos ligada ao conceito muitas vezes polêmico de "erro" e que pode, portanto, ser utilizada com o valor de exatidão, rigor, escolha atenta, presente no original. Não obstante, por comodidade, decidimos usar a palavra "erro" para indicar as "agramaticalidades" presentes nos textos analisados. 
Nossa referência para a escolha dos critérios e das medidas foi em especial a publicação de Wolfe-Quintero et al. (1998) citada na introdução, em que, levando-se em consideração 39 estudos e mais de 100 medidas diferentes, procurou-se estabelecer quais são as variáveis e os cálculos mais confiáveis e, portanto, “melhores” (WOLFE-QUINTERO et al., 1998: 117-127) para obter valores numéricos que correspondam à fluência, à precisão e à complexidade dos trabalhos de aprendizes. No livro são dadas indicações sobre como se pode proceder na avaliação e na análise de textos escritos, para os quais devem ser consideradas características obviamente diferentes daquelas escolhidas para as produções orais. $\mathrm{O}$ estudo reflete sobre as conseqüências a que esse tipo de análise permite chegar para que se possam fazer afirmações tanto gerais quanto específicas acerca do desenvolvimento da escrita dos aprendizes envolvidos nas pesquisas e dos resultados alcançados por eles.

Um ponto importante é que o estudo realizado por Wolfe-Quintero e seus colaboradores se concentrou no exame de produções escritas vistas como atos comunicativos e contrapostas a exercícios escritos realizados pelos aprendizes privilegiando a atenção às formas ${ }^{90}$. Nesse sentido, a perspectiva adotada coincide perfeitamente com a nossa, já que as produções aqui analisadas foram elaboradas pelos discentes sem a focalização de um ponto gramatical ou de uma estrutura lingüística específica, mas com o objetivo comunicativo mais abrangente de analisar um texto literário.

\footnotetext{
${ }^{90}$ Seria esse o caso se, após uma aula de gramática explícita sobre, por exemplo, pretérito imperfeito, o professor pedisse aos alunos a elaboração de um texto sobre seus hábitos num momento do passado, ainda sugerindo explicitamente a utilização desse determinado tempo verbal. A atenção dos alunos estaria concentrada mais na utilização correta do tempo verbal estudado do que na "comunicação" produzindo certamente resultados diferentes daqueles alcançados numa produção centrada no sentido.
} 
Nos estudos em que são postas a prova a validade e a confiabilidade desses critérios de avaliação é utilizada como base da maior parte das medições a chamada $T$-unit, que decidimos tomar então como unidade de referência em quase todas as medidas escolhidas.

A T-unit é definida por Kellogg Hunt (1965) como uma "minimally terminable unit", isto é, uma unidade mínima, que pode ser considerada terminada e que se prefere à oração por ser mais precisamente identificável e mais objetivamente reconhecível. Num estudo posterior, o mesmo Hunt define as T-units da seguinte maneira: "as mais breves unidades nas quais pode ser dividido um trecho de discurso sem deixar fragmentos residuais"91 e explica que cada T-unit é constituída por uma única oração independente com todas as subordinadas a ela ligadas ou nela "encaixadas". As coordenadas não entram nessa contagem, por serem consideradas, por sua vez, unidades independentes. Tudo isso significa que no exemplo:

\section{Luca aveva una buona memoria, | ma ora non ce l'ha più.}

teremos duas T-units, por ser a oração, após a primeira independente, uma coordenada.

Se, ao contrário, dissermos:

Luca non ha più la buona memoria che aveva prima.

ou

Luca, che prima aveva una buona memoria, ora non ce l'ha più.

91 "[...] the shortest units into which a piece of discourse can be cut without leaving any sentence fragments as residue" (1970: 189). 
teremos apenas uma T-unit, já que, junto com a oração principal, há uma oração subordinada relativa, que no primeiro caso começa no final da oração principal, enquanto no segundo caso é “encaixada" na principal e separa sujeito e predicado.

Embora originariamente definida para acompanhar o desenvolvimento sintático do trabalho escrito de crianças no processo de aprendizagem de sua primeira língua, a T-unit foi amplamente usada em pesquisas desenvolvidas no âmbito da aquisição/aprendizagem de línguas nãomaternas, isto é, todas as línguas diferentes da primeira, tanto num contexto de língua estrangeira quanto num contexto de língua segunda, e serviu como base para uma grande variedade de medidas, criadas nos diferentes estudos, quer para determinar o nível de complexidade, quer para estabelecer valores para a fluência e a precisão.

Antes de definirmos de que maneira foram calculadas aqui a precisão, a fluência e a complexidade (tanto gramatical quanto lexical), precisamos fazer mais uma observação geral sobre a diferença entre medidas de freqüência (frequency measures) e de proporção (ratio measures).

Para medir a freqüência são contadas as estruturas de um determinado tipo (por exemplo, palavras, orações ou T-units) presentes nas produções de aprendizes e a comparação é feita com base no tempo à disposição dos discentes para a realização da "tarefa" ou, então, a partir do tipo de "tarefa" a ser executada. Esse tipo de cálculo dificulta, porém, a comparação entre um aluno e outro, entre vários momentos no percurso de aprendizagem de um mesmo aluno e entre um estudo e outro, pois, nessas avaliações, o ponto de partida é externo às produções dos discentes. 
As medidas proporcionais, que escolhemos aqui, eliminam esse inconveniente, já que, utilizando um elemento comparável como referência para o cálculo - em geral, a oração ou a $T$ unit -, podem ser obtidos valores "normalizados" e, por isso, mais facilmente equiparáveis. Assim, a extensão de uma redação não modifica os dados finais, quando o objetivo é, por exemplo, calcular a complexidade ou a variação lexical, que, em princípio, independem da "quantidade" de palavras; ou o fato de haver um maior ou menor número de T-units não altera a confiabilidade do resultado final no momento em que se calcula a precisão ou a fluência.

\section{FLUÊNCIA}

Passemos agora às medidas escolhidas e comecemos pela fluência (fluency). Essa característica das redações foi calculada dividindo o número total das palavras de uma redação pelo número de $T$-units de que era composta (W/T-words/T-units), obtendo assim a média de palavras por T-unit. Quanto maior o resultado, isto é, o número médio de palavras em cada $T$ unit, maior a fluência da redação.

Pode parecer estranho termos escolhido essa medida para produções escritas, já que geralmente o conceito de fluência se aplica a produções orais, nas quais se considera mais fluente o aprendiz que produz um maior número de palavras num determinado período de tempo e que não interrompe ou reformula com freqüência sua fala. No entanto, mesmo em produções escritas o critério da fluência pode ser um indicador importante do desenvolvimento do aluno. De fato, a maior fluência depende do maior número de palavras por cada unidade e isso demonstra "facilidade" na escrita por parte do aprendiz, que prova dessa maneira ser capaz de fixar a caneta 
no papel sem interrupções que poderiam caracterizar paradas e rupturas no pensamento e na produção coerente do discurso.

É óbvio que só o "escrever fluente" não implica necessariamente uma escrita de qualidade elevada, nem pressupõe precisão gramatical ou que o aprendiz esteja aproximando-se da língua alvo assim como é utilizada por falantes nativos. Com efeito, uma redação pode ser fluente e longa, mas conter apenas períodos vazios. Não obstante, a extensão da produção escrita e, em especial, sua fluência podem indicar o desenvolvimento da familiaridade com a língua estrangeira e o quão "confortável” o aluno se sente utilizando essa língua.

Além disso, escrever com fluência na língua estrangeira significa ser capaz de "recuperar" com tranqüilidade os elementos lingüísticos necessários para expressar sentido(s), privilegiando$\mathrm{o}(\mathrm{s})$ em relação à forma. Portanto, uma produção escrita fluente pode indicar que o aluno pôs a “comunicação" em primeiro plano, o que não implica necessariamente que cuidou em paralelo da precisão.

É também verdade que muitas vezes elementos lingüísticos aprendidos e estruturas fixas integradas contribuem para um crescimento da performance medida pela fluência (SKEHAN, 1998: 5). De fato, o tempo de contato com a língua e a conseqüente repetição de certas formulações permitem que os aprendizes as utilizem com uma naturalidade cada vez maior e que possam, portanto, desenvolver uma relação mais "desenvolta" com a língua, escrevendo com um menor número de interrupções e podendo assim produzir unidades mais longas. 


\section{PRECISÃO}

Para calcular a precisão dos textos (accuracy) foram contados todos os "erros" presentes nos trabalhos dos alunos, que foram depois divididos pelo número de T-units de cada redação, de modo a chegar à média de erros por cada T-unit $(\mathrm{E} / \mathrm{T})$. As produções mais "precisas" são aquelas em que os aprendizes procuraram usar seu sistema interlingüístico, independente do nível de proficiência já alcançado, para produzir na língua alvo um output possivelmente correto (SKEHAN, 1998: 5).

Cabe dizer que, no cálculo da precisão de uma produção escrita, a melhor performance é obtida quando o valor do resultado diminui. Em outras palavras: quanto mais próximo de zero for o resultado, melhor a performance do aluno, pois zero indica a ausência de agramaticalidades na produção, isto é, ausência de formas lingüísticas que não foram geradas pelas regras da gramática da língua estrangeira.

Estabelecer claramente o que se entende por "erro" não é tarefa fácil. Partimos aqui de uma definição de Lennon segundo o qual erro é "uma forma ou uma combinação de formas lingüísticas que, no mesmo contexto e em condições de produção parecidas, com toda probabilidade, não seriam produzidas por falantes nativos". ${ }^{92}$ A referência é, portanto, o falante nativo que nessa definição é considerado como produtor (erro é algo que o falante nativo naquela mesma condição não produziria) e que na nossa avaliação das redações dos alunos foi também

\footnotetext{
92 "A linguistic form or combination of forms which, in the same context and under similar conditions of production, would, in all likelihood, not be produced by the speakers' native speaker counterparts”' (LENNON, 1991: 182).
} 
considerado como receptor, de modo que consideramos agramatical aquilo que um falante nativo teria dificuldade de entender ou não entenderia.

Visando a ter valores mais precisos e informações mais detalhadas sobre a precisão nas produções dos discentes, os erros foram, num segundo momento, divididos em três níveis. Obtivemos assim o número de erros de primeiro, de segundo e de terceiro nível.

As manifestações escritas que se afastavam "levemente" da norma ortográfica e/ou morfossintática do italiano foram classificadas como erros de primeiro nível (E1). O critério utilizado para que um erro fosse julgado "leve" era que não interferiria na comunicação e poderia ser entendido sem dificuldade por um falante nativo. Os erros considerados de segundo nível (E2) eram, ao contrário, constituídos por formas lingüísticas que, distanciando-se em maior medida da ortografia, da morfologia, da sintaxe e do léxico do italiano, criariam "estranhamento" num falante nativo e poderiam representar obstáculos para o sucesso da comunicação. Por último, foram tratados como erros de terceiro nível (E3) aqueles que deram lugar a formas lingüísticas próximas da incompreensibilidade, sempre tomando como referência um falante nativo.

Vê-se que não teve peso na classificação dos erros sua categoria gramatical, nem a progressão de estruturas prevista pelos programas de cada um dos semestres. Foi considerado apenas o "efeito comunicativo" das agramaticalidades, inclusive porque era claro que o objetivo principal dessas redações era que os alunos "comunicassem" sua própria análise do texto literário, argumentando, com base no próprio texto, e explicando a pertinência e a produtividade de sua leitura. 
É óbvio que falar em "grau de agramaticalidade" de uma forma lingüística implica a participação da subjetividade de quem julga e pode, portanto, produzir resultados distintos, dependendo da competência lingüística do sujeito que emite seu parecer, da variedade da língua alvo escolhida como base, do registro tomado como referência, etc.

Sabendo dos limites desse tipo de avaliação, procuramos reduzir a margem de subjetividade discutindo os critérios para a classificação dos três níveis de "erros" com um corretor externo, falante nativo e professor de italiano para estrangeiros, ao qual foi deixada a palavra final nos casos dúbios.

De qualquer maneira, é importante sublinhar que foram levados em conta somente aqueles que podem ser denominados "erros absolutos", isto é, erros que dificilmente não seriam reconhecidos como tais por falantes nativos no mesmo contexto e/ou em situação de produção comparável.

A título de exemplo e para que se possa ter uma idéia mais clara do tipo de trabalho realizado, reproduzimos aqui em baixo a avaliação de um trecho da redação $\mathrm{H} 1$ (aluno $\mathrm{H}, 1^{\circ}$ semestre). O número entre parênteses indica o nível do erro e é seguido pela forma correta sugerida:

(1) In questo testo ci sono due elementi contrapposti che tormentano il protagonista: aveva una memoria molto bona $(1 ;$ buona $)$, però, adesso ha una pessima memoria.

(2) Con $(2 ; a d)$ appena trent' anni lui non accetta la perdita della memoria.

(3) Tenta inventare ( 2 ; tenta $d i$ inventare) un sistema che la induca a funzionare.

(4) Tenta vincere (2; tenta $d i$ vincere) lo tempo (2; il tempo), fa un patto con il destino. Tutto per ricordare un nome.

(5) Nel momento in che (2; in cui) ricorda il nome, Luca, felice e esausto, è morto (3; $\grave{e} /$ viene ucciso $)$ per $(3 ; d a)$ un'auto in mezzo alla strada. 


\section{COMPLEXIDADE}

Entende-se por complexidade (complexity) o nível de variação sintática que se manifesta na língua escrita por meio da riqueza de estruturas, graças às quais os aprendizes escrevem de forma mais elaborada. Considera-se, portanto, que um elevado nível de complexidade numa produção escrita significa que o aprendiz dispõe tanto de estruturas sintáticas básicas quanto de estruturas sofisticadas e que é capaz de escolher aquelas que melhor se adaptam às suas necessidades expressivas.

Há várias maneiras de medir a complexidade sintática de um texto escrito. Em alguns casos, a análise foi feita a partir do aumento no uso da voz passiva ou então de alterações na utilização do sistema pronominal (cf. WOLFE-QuinTERO et al., 1998: 74). Nesses estudos os elementos lingüísticos citados foram tomados como referência, pois se partiu do pressuposto de que indicariam um crescimento geral da complexidade das produções escritas.

Embora esse tipo de cálculo se tenha revelado útil para algumas medições específicas, chegamos à conclusão que não seria adequado para uma pesquisa como a nossa, na qual as redações são o resultado de um trabalho realizado em sala de aula, que não excluía instruções explícitas de gramática e poderia, portanto, estimular a utilização de uma determinada estrutura morfossintática, privando-a assim de sua função de índice de uma tendência. 
Após avaliar as medidas consideradas confiáveis no cálculo da complexidade sintática, julgamos que um bom indicador do desenvolvimento atingido numa produção em língua estrangeira escrita nas condições dadas poderia ser a subordinação e escolhemos, portanto, utilizar os seguintes critérios proporcionais:

1) o número de orações subordinadas em relação ao número total de orações $(D C / C$ = dependent clause/clauses);

2) o número total de orações subordinadas por $T$-unit $(D C / T=$ dependent clauses $/ T$ unit).

Embora o estudo de Wolfe-Quintero et al. afirme nos dois casos uma elevada confiabilidade (1998: 99), decidimos utilizar ambos os critérios de modo a poder comparar os resultados obtidos.

O que nos interessava era, em primeiro lugar, observar o desenvolvimento da subordinação, pois, especialmente as pesquisas que levam em consideração uma ampla escala de níveis, provaram que há uma correspondência entre o desenvolvimento da subordinação e o nível de proficiência. De fato, foi verificado que, em geral, os aprendizes passam da coordenação à subordinação à medida que se tornam mais proficientes na língua estrangeira, chegando, ao longo de seu percurso, a utilizar um número maior de subordinadas internas e de orações reduzidas de gerúndio, infinitivo e particípio (cf. WOLFE-QUINTERO et al., 1998: 73). No entanto, uma vez estabilizado o sistema sintático, todas as estruturas convivem e são utilizadas por aprendizes proficientes conforme o tipo de texto e as necessidades que ele apresenta. 
É por isso que, embora um estudo que considere as características da subordinação possa fornecer muitas reflexões produtivas (cf. IMAZU/VALERI, 2004), não diferenciamos entre os tipos de orações subordinadas às quais, na nossa contagem, reservamos sempre o mesmo tratamento.

Antes de concluir essas observações sobre o cálculo da complexidade sintática, precisamos dizer que, para poder dispor de mais um termo de comparação para os dados obtidos, além das medidas que levam em conta a subordinação, utilizamos também um terceiro cálculo proporcional realizado contando o número total de orações - tanto independentes quanto subordinadas - e dividindo-o pelo número de $T$-unit $(C / T=$ clauses $/ T$-unit $)$.

Nas três medidas utilizadas a performance do aluno é considerada melhor quando o valor numérico que resulta do cálculo sobe, pois a um número maior corresponde um maior grau de subordinação e, portanto, de complexidade.

VARIAÇÃOLEXICAL

Às medidas de fluência, precisão e complexidade sintática acrescentamos o critério, também citado no livro de Wolfe-Quintero (1998), de variação lexical, que indica uma complexificação e uma maior variedade na escolha de lexemas da língua estrangeira no momento da produção escrita e fornece, portanto, indícios sobre o repertório de vocabulário ativo do qual os aprendizes dispõem. 
Possuir um vocabulário amplo e adequado a registros e contextos diferentes é, sem dúvida, um requisito essencial para uma efetiva comunicação, isto é, para poder expressar idéias de forma precisa e "fazer-se entender". É, por isso, que resolvemos incluir também a medida da complexidade lexical das redações dos aprendizes, que pode ser calculada em termos de variedade e de sofisticação. Esta revela se os alunos aprenderam e usam também lexemas que não pertencem ao vocabulário cotidiano ${ }^{93}$, enquanto aquela procura identificar a variação no interior de um texto, isto é, se o aprendiz utiliza palavras diferentes e evita as repetições.

Na nossa avaliação das redações optamos pela variedade lexical, que foi medida segundo a proporção chamada type-token, na sua versão mais elaborada, ou seja, dividindo o número de palavras lexicais que não se repetiam no texto (types) pela raiz quadrada do dobro do número total dessas palavras, inclusive as repetidas (tokens). Preferimos essa fórmula porque permite corrigir as diferenças no resultado que seriam causadas pela extensão da redação. De fato, operando com ela, um maior número de palavras diferentes num texto mais curto conta mais do que a mesma proporção de palavras num texto mais longo. Por causa da utilização dessa fórmula, os resultados obtidos são comparáveis e podem ser cotejadas tanto as produções do mesmo aprendiz em momentos distintos, quanto as produções de aprendizes diferentes realizadas no mesmo momento.

\footnotetext{
${ }^{93}$ Para o cálculo da sofisticação lexical são geralmente utilizados dicionários de freqüência e programas informáticos que reconhecem as cerca de 2.000 palavras mais freqüentes nas diferentes línguas. Para o italiano pode ser utilizado o programa contido no disquete que acompanha o livro Guida all'uso delle parole de Tullio De Mauro a partir da $12^{\text {a }}$ edição (1997), embora ele seja já tecnicamente obsoleto. Outra possibilidade é o dicionário do próprio De Mauro (Il dizionario della lingua italiana) que sempre reproduz ao lado dos lexemas as ditas "marcas de uso". O dito vocabolario fondamentale identificado com a sigla FO inclui as 1.991 palavras mais freqüentes.
} 
CONSIDERAÇÕES SOBRE OS DADOS DE FLUÊNCIA, PRECISÃO, COMPLEXIDADE E VARIAÇÃO LEXICAL NAS PRODUÇÕESDOSAPRENDIZES

Examinemos agora os valores que resultaram da avaliação das produções escritas dos dez aprendizes escolhidos, começando pela média de todos os critérios que foi calculada e reproduzida nos gráficos da FIGURA 1, após medir a fluência, a precisão, a complexidade sintática e a variação lexical das seis redações de cada aluno.

Observando os gráficos, chama a atenção que em todas as medidas as linhas são ascendentes $^{94}$ e, se se levam em conta o primeiro e o último resultado, apontam sempre para um progresso dos alunos ao longo de seu percurso de aquisição/aprendizagem da língua estrangeira. Em geral, podemos afirmar então que, após os três anos de curso, os aprendizes escrevem de forma mais fluente e sintaticamente mais complexa e que diminui a repetição das mesmas palavras e o número de agramaticalidades.

No entanto, se olharmos com mais atenção as linhas dos gráficos e os números que as geraram, percebemos que a situação não é tão simples e linear como essa primeira observação pareceria indicar: é verdade que os resultados melhoram levando em conta o início e o fim do percurso, mas é também verdade que isso acontece para cada medida de forma diferente. Pode ser útil, portanto, refletir sobre as médias dos dados e observá-las mais detidamente.

\footnotetext{
${ }^{94}$ Note-se que para a precisão (tanto a "geral", quanto a dividida em "níveis de erro") os valores da média foram posicionados no eixo em ordem inversa, pois, como já dissemos, nessa medida uma redução do valor numérico indica uma melhor performance por parte dos alunos, que, ao aproximar-se do zero, chega mais perto de uma maior precisão. A inversão da ordem permitiu representar graficamente o progresso como subida e o retrocesso como queda, de modo que os dados da precisão fossem visualmente comparáveis com os outros valores, para os quais um número maior indica um resultado melhor.
} 
Além disso, sabemos que o cálculo da média pode achatar as variações individuais. De fato, o processo de aquisição/aprendizagem da língua estrangeira revela-se ainda mais complexo e irregular, se analisarmos os dados das redações de cada aluno, cujas diferenças se tornam evidentes nos gráficos realizados a partir dos valores individuais (FIGURAS 2-6).

Observando-os, percebemos que o uso e a aquisição da língua estrangeira não mostram um progresso sempre contínuo e gradual e que as mudanças se apresentam mais como uma adaptação dinâmica dos aprendizes ao sistema do que como um processo previsível. De fato, fluência, complexidade, variação lexical e precisão emergem de uma forma que não pode ser vista como o desdobrar-se de um plano controlável e integrado, mas como um sistema mutável no qual há instabilidades e transformações, às vezes, repentinas que podem anunciar a chegada de uma “ordem” qualitativamente diferente em relação aos momentos anteriores.

Essas reflexões são particularmente interessantes no nosso contexto, pois estamos analisando as produções de aprendizes que adquirem a língua num curso universitário e que, portanto, recebem instrução formal e seguem uma programação pré-determinada. Mesmo levados pela estruturação do curso e pelas indicações do professor a desenvolver específicas “necessidades lingüísticas”, esses alunos mostram que existem muitos caminhos no percurso de aquisição/aprendizagem de uma língua estrangeira e confirmam a hipótese da assimetria entre insumo lingüístico (input), instrução e produção (output).

Mas vejamos agora o que dizem os dados. 
MÉDIA GERAL: TODAS AS MEDIDAS

(FIGURA 1)

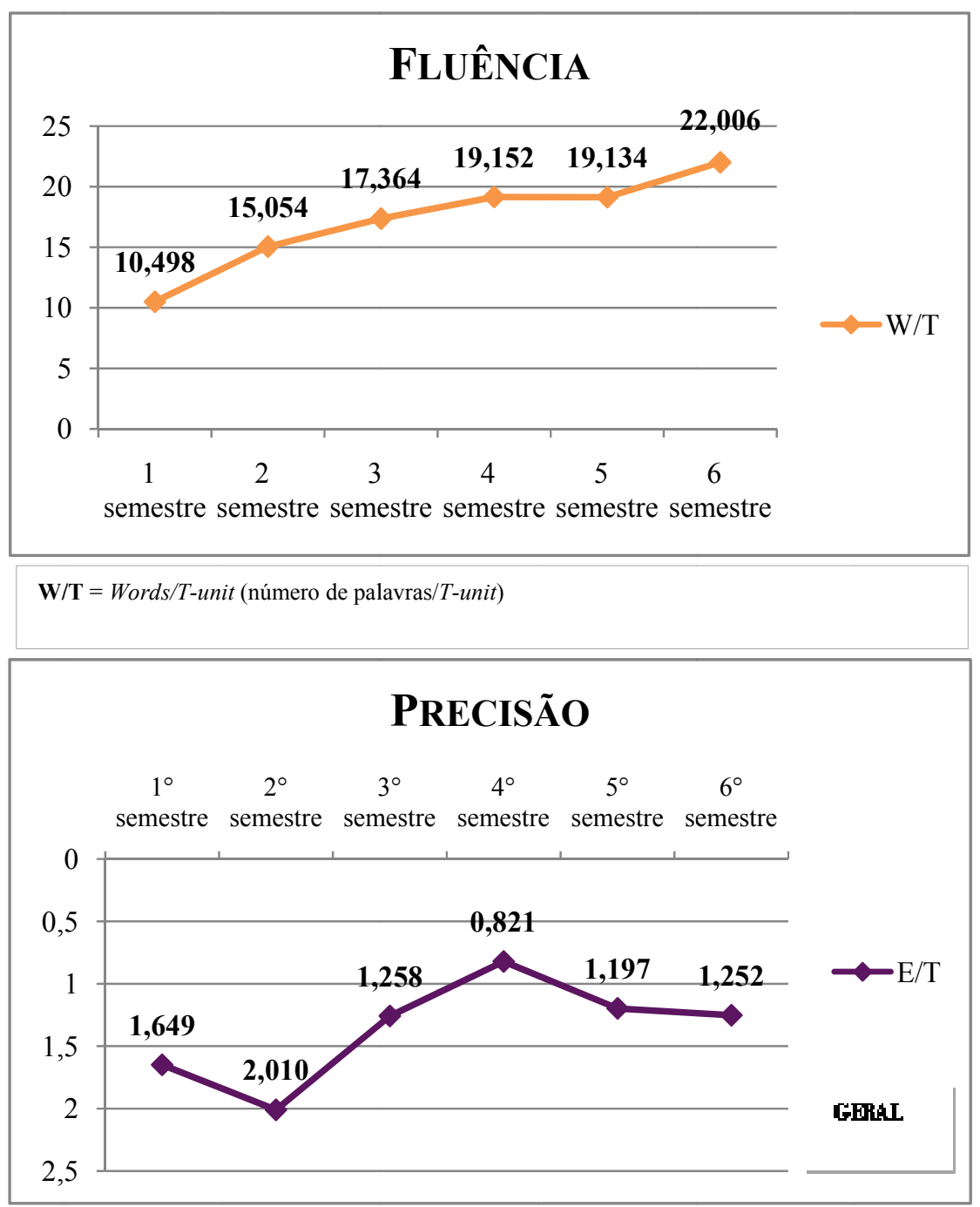

$\mathbf{E} / \mathbf{T}=$ número total de erros/T-unit

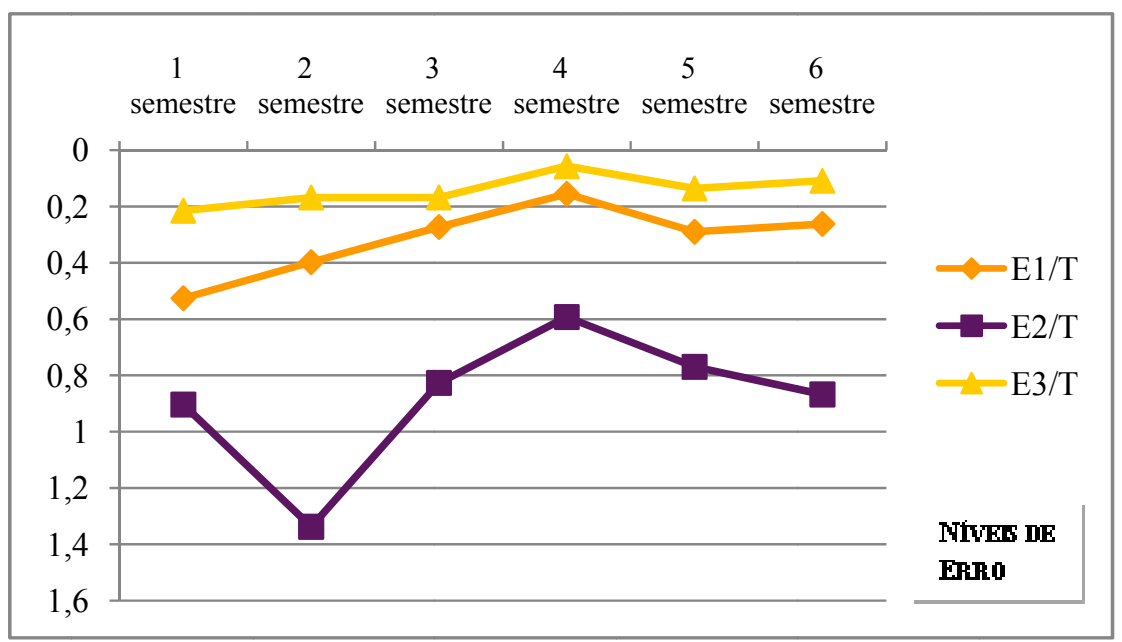

$\mathbf{E 1} / \mathbf{T}=$ número de erros de nível 1/T-unit; $\mathbf{E 2 / T}=$ número de erros de nível 2/T-unit; $\mathbf{E 3 / T}=$ número de erros de nível 3/T-unit 
MÉdia GERAL: TODAS AS MEDIDAS

(FIGURA 1 - parte 2)

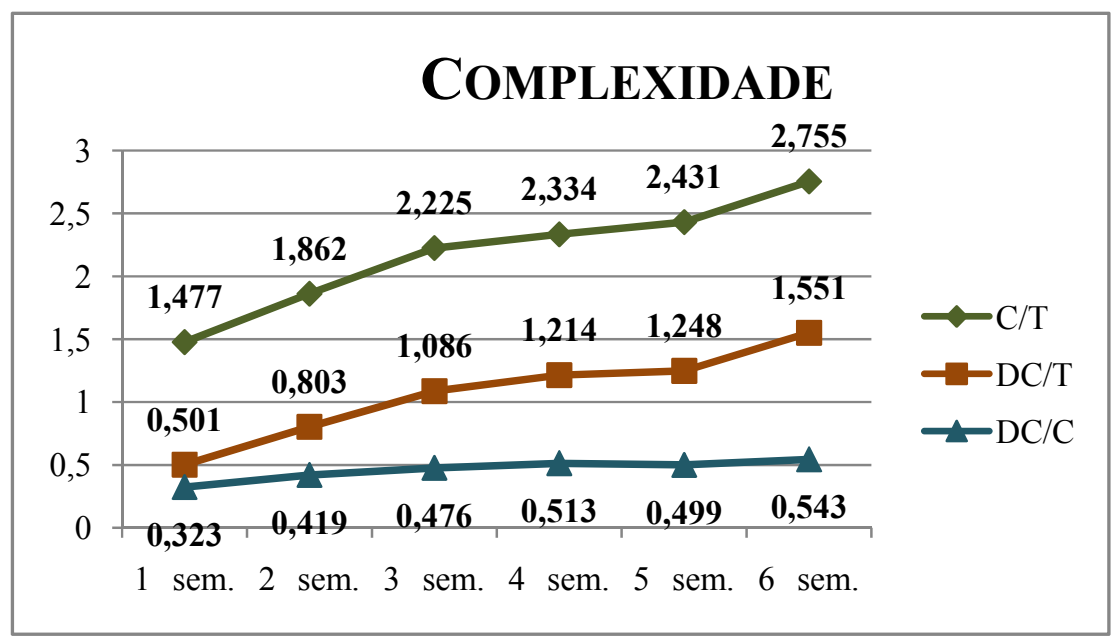

$\mathbf{C} / \mathbf{T}=$ Clauses $/$ T-unit (orações/T-unit); DC/T = Dependent Clauses $/ T$-unit (orações subordinadas/T-unit); DC/C = Dependent Clauses/Clauses (orações subordinadas/orações)

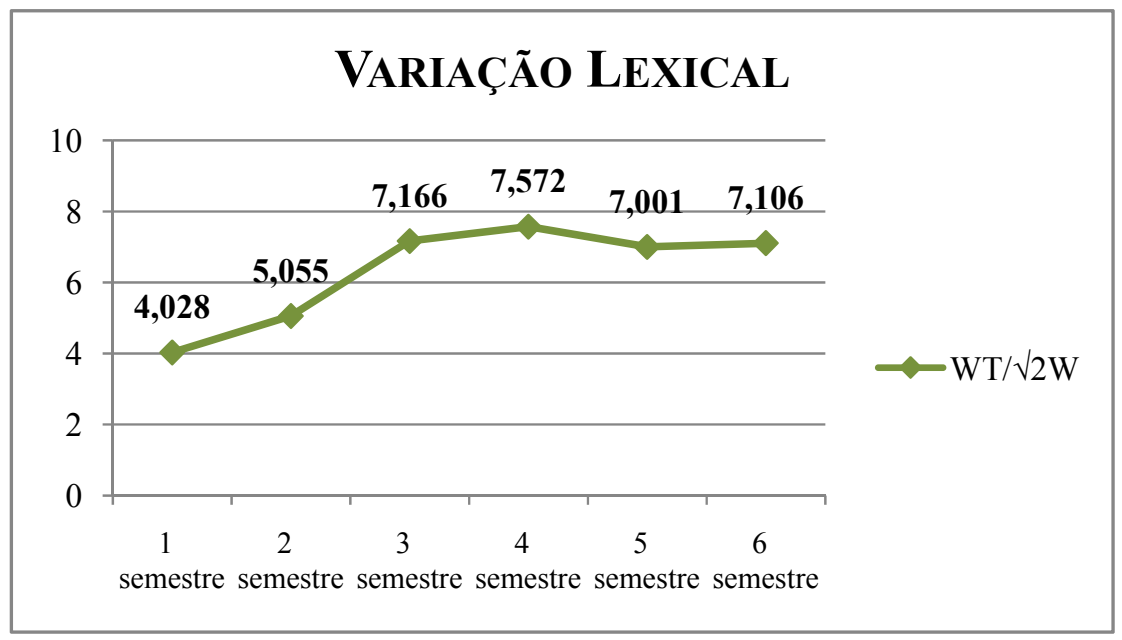

$\mathbf{W T} / \sqrt{ } \mathbf{2} \mathbf{W}=$ Words type $/ \sqrt{ } 2$ Words (número de palavras lexicais diferentes dividido pela raiz quadrada do dobro de todas as palavras lexicais) 
FLUÊNCIA - Figura 2

(número de palavras / T-unit)

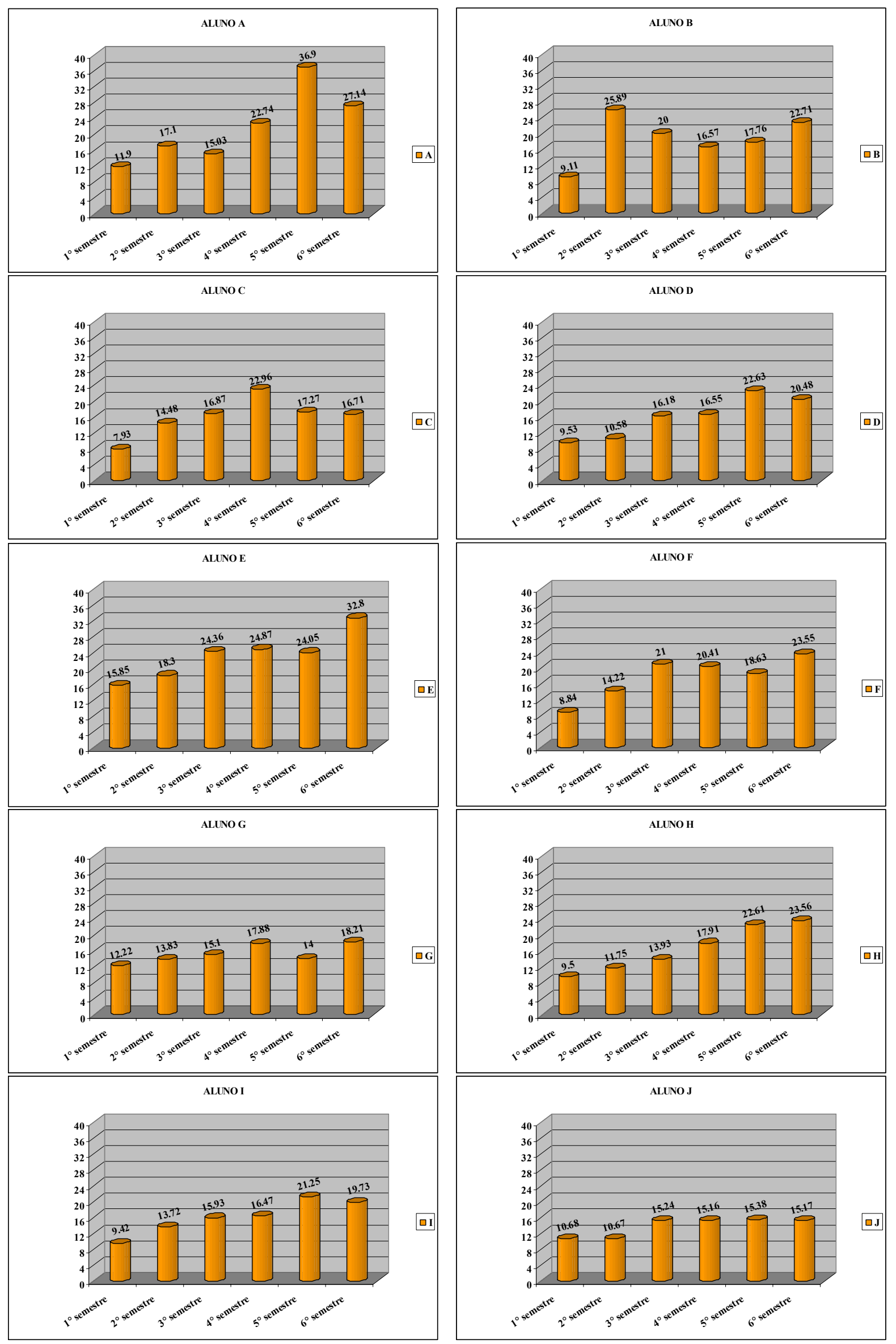


Precisão - Figura 3

(GERAL - número de erros/T-unit)

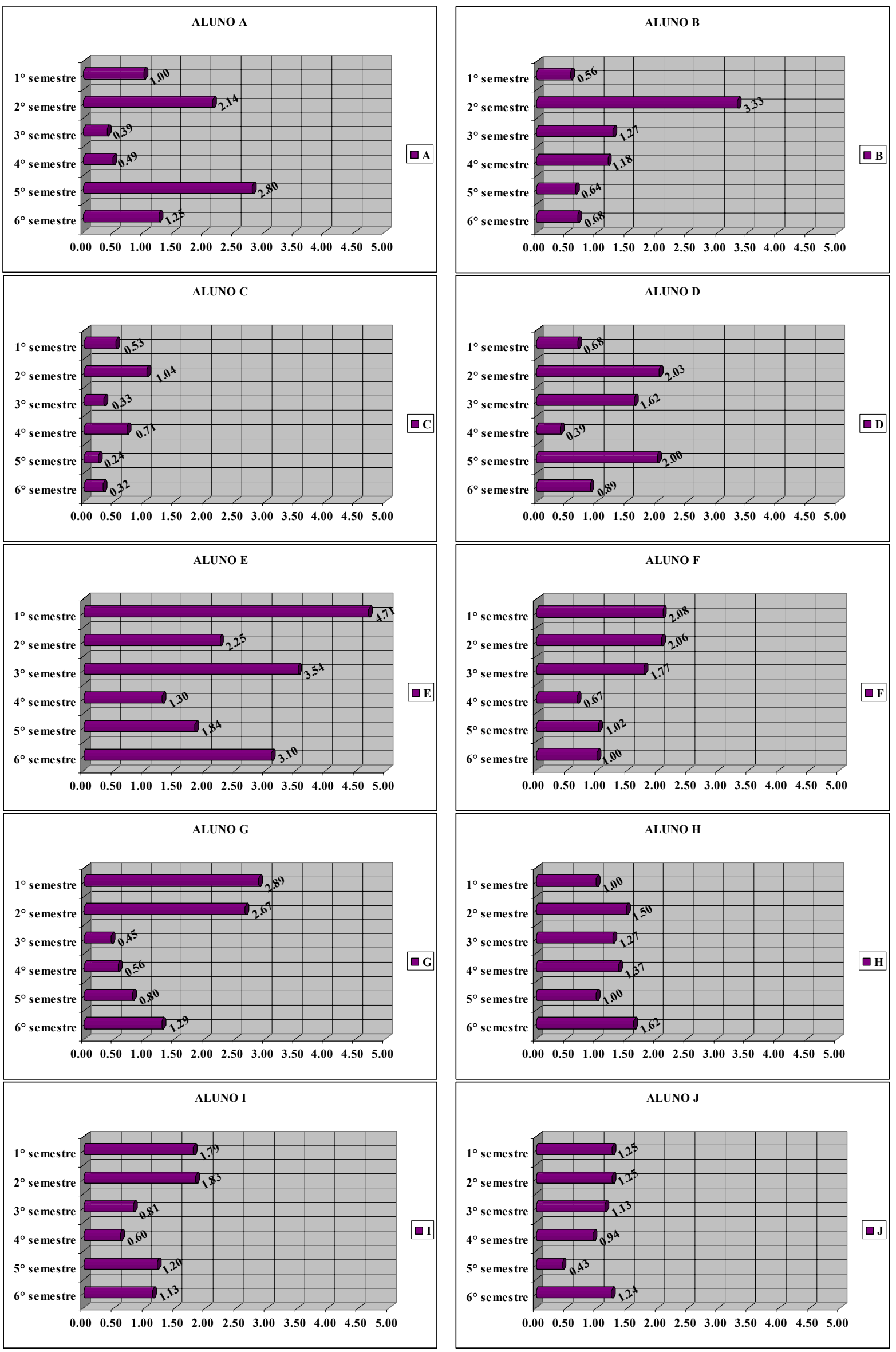


Precisão - Figura 4

(NíVEIS DE ERRo - número de E1, E2, E3/T-unit)
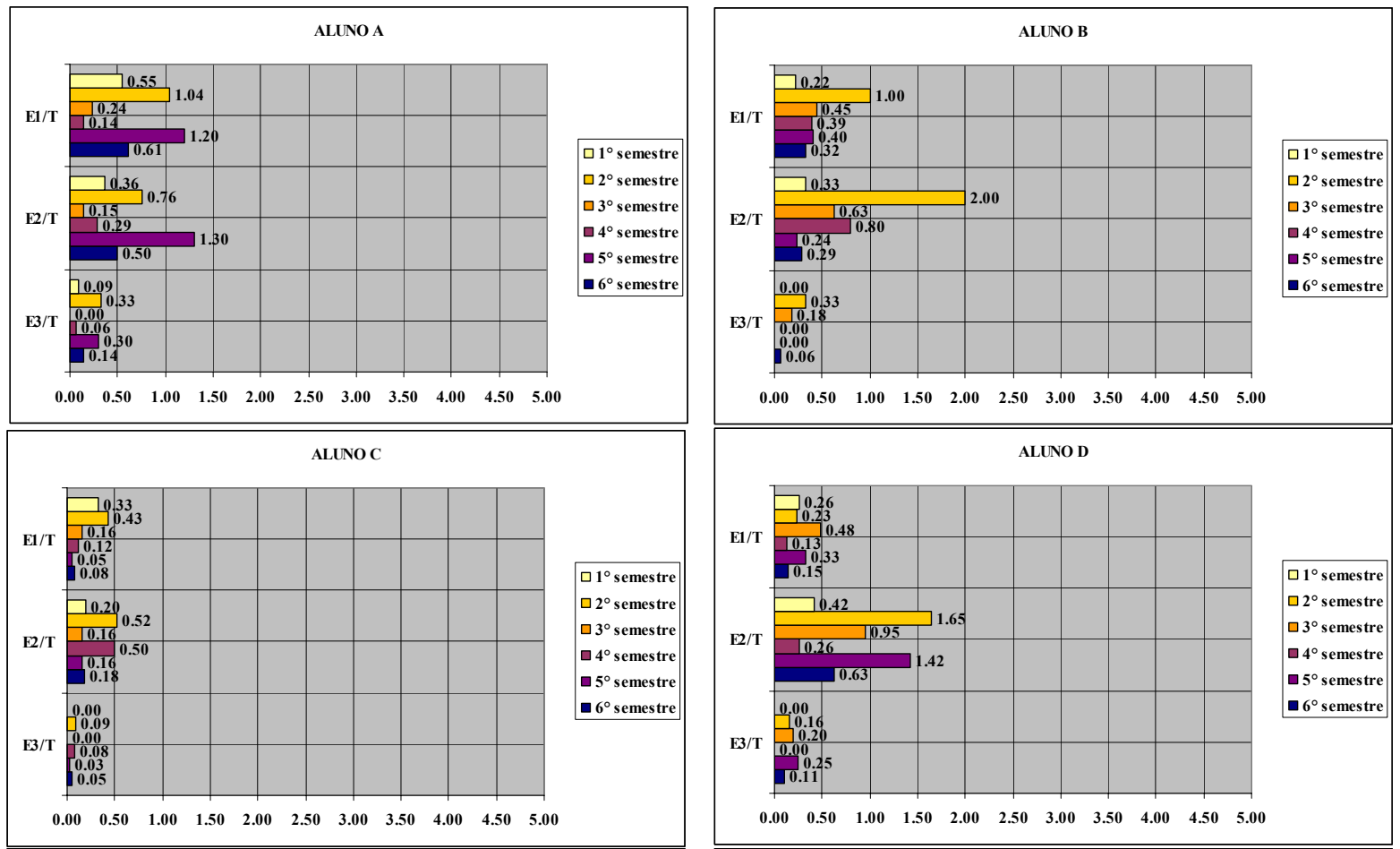

ALUNO E
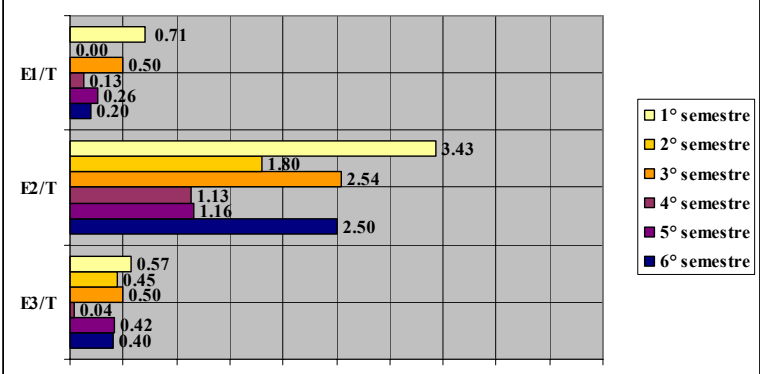
$\square 2^{\circ}$ semestre $\square 3^{\circ}$ semestre $\square 4^{\circ}$ semestre $\square 5^{\circ}$ semestre - $6^{\circ}$ semestre

$\begin{array}{lllllllllll}0.00 & 0.50 & 1.00 & 1.50 & 2.00 & 2.50 & 3.00 & 3.50 & 4.00 & 4.50 & 5.00\end{array}$

ALUNO G

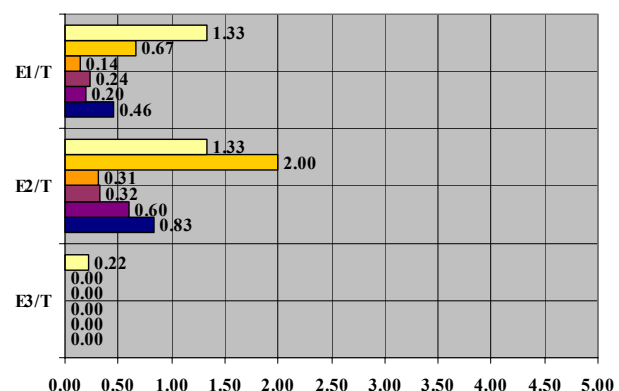

$\square 1^{\circ}$ semestre $\square 2^{\circ}$ semestre $\square 3^{\circ}$ semestre $\square 4^{\circ}$ semestre $\square 5^{\circ}$ semestre - $6^{\circ}$ semestre

$\begin{array}{lllllllllll}0.00 & 0.50 & 1.00 & 1.50 & 2.00 & 2.50 & 3.00 & 3.50 & 4.00 & 4.50 & 5.00\end{array}$

ALUNO I

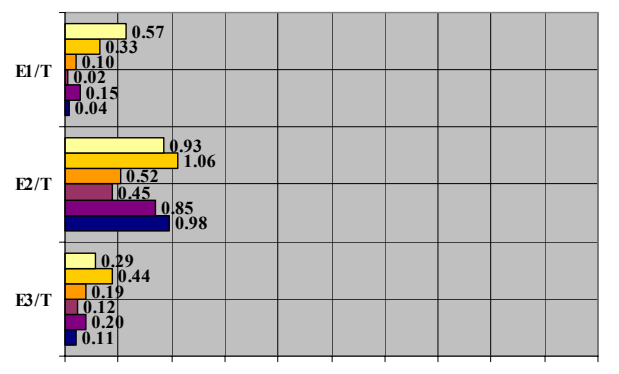

$\square 1^{\circ}$ semestre $\square 2^{\circ}$ semestre $\square 3^{\circ}$ semestre $\square 4^{\circ}$ semestre $\square 5^{\circ}$ semestre $\square 6^{\circ}$ semestre

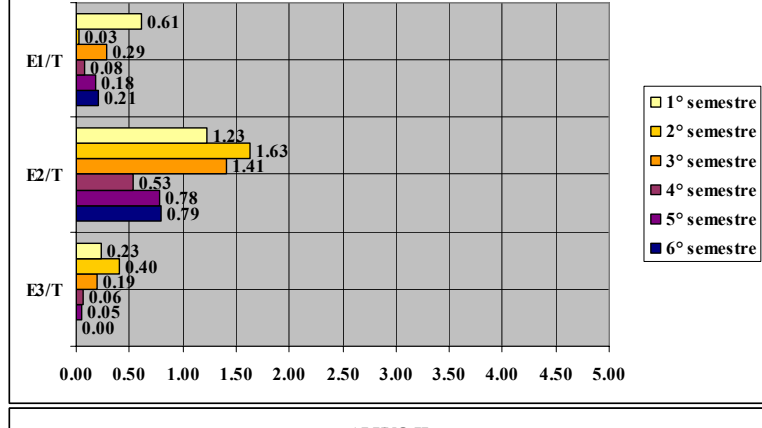

ALUNO H
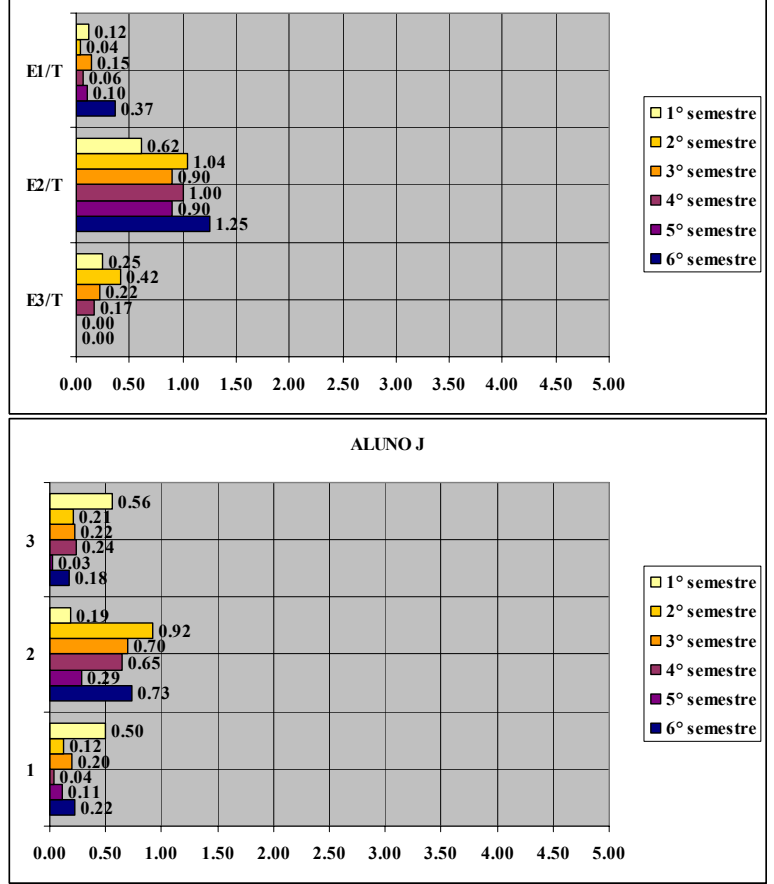
COMPLEXIDADE - FigURA 5

(DC $=$ dependent clause $=$ oração subordinada $; \mathrm{C}=$ clause $=$ oração $; \mathrm{T}=\mathrm{T}$-unit $)$

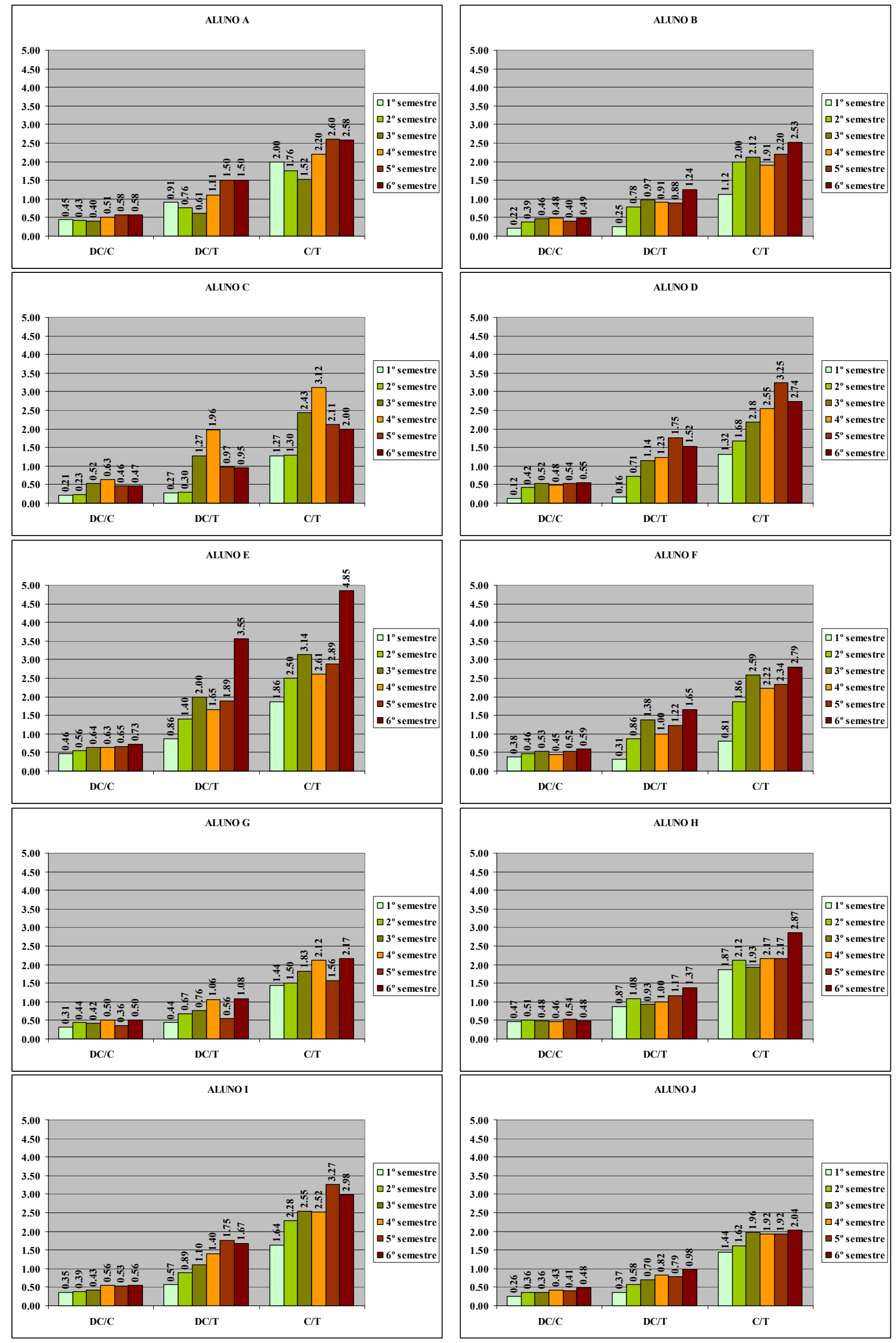


VARIAÇÃO LEXICAL - FIGURA 6

(WT $/ \sqrt{ } \mathbf{2} \mathbf{W}=$ Words type $/ \sqrt{ } 2$ Words $)$
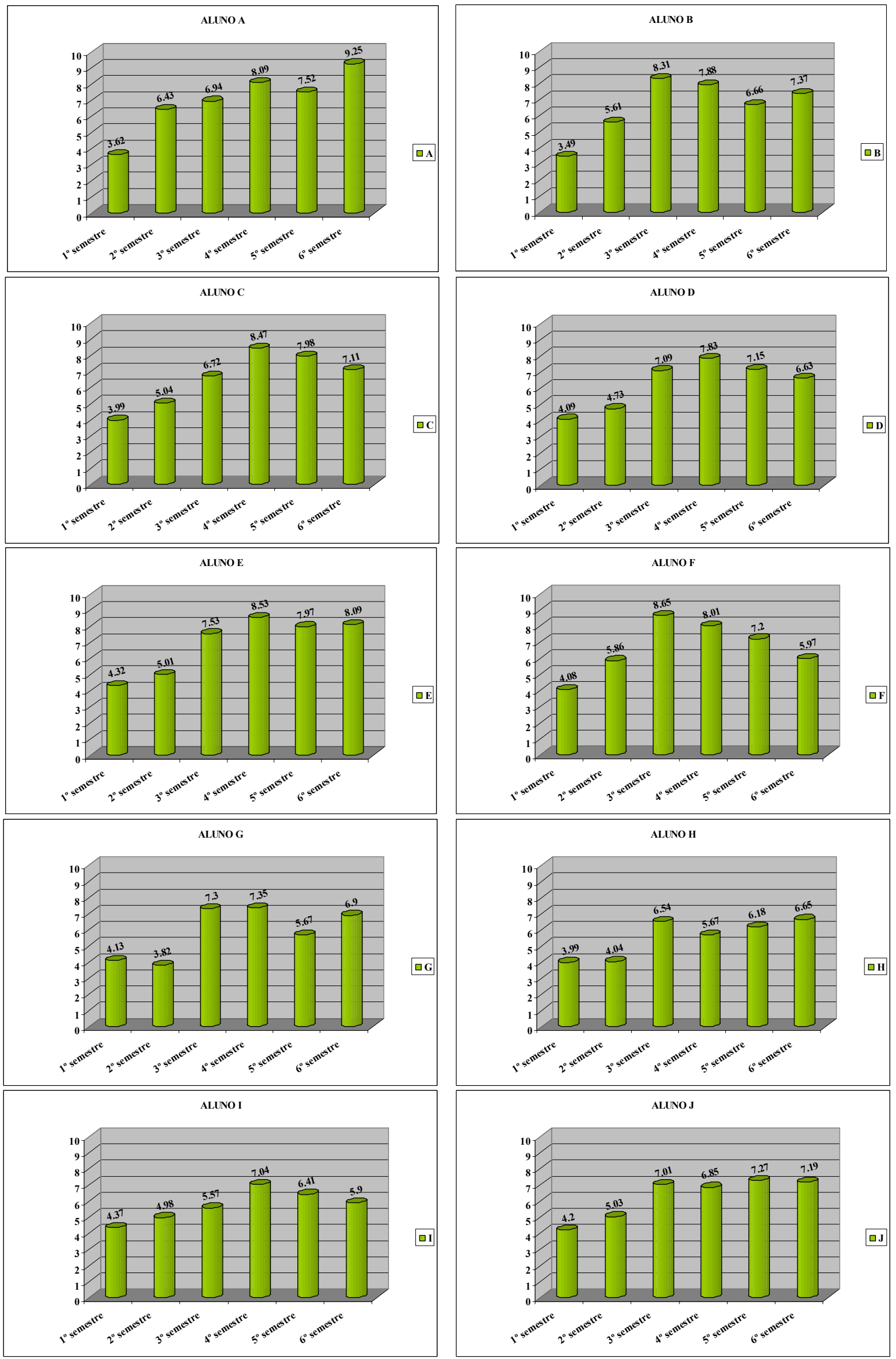
Uma vez examinados mais atentamente os gráficos - tanto da média, quanto das variações individuais -, podemos chegar a algumas conclusões sobre tendências e características do percurso de aprendizagem dos alunos que participaram do nosso curso experimental.

Comecemos pela média dos dados relativos à fluência, visualmente representada no gráfico por uma curva ascendente, que evidencia um aumento bastante regular do valor geral ao longo do curso. Somente entre o quarto e o quinto semestre há um quase imperceptível retrocesso (de 19,152 para 19,134 palavras por T-unit), após o qual o resultado volta a subir, de modo que no último semestre se alcança, em absoluto, o maior valor.

O aumento da média geral é confirmado também pela análise das variações individuais, visto que, embora haja nos gráficos de alguns discentes picos intermediários, a maioria apresenta os valores mais elevados entre o quinto e o sexto semestre. $\mathrm{O}$ andamento dos valores da fluência dos alunos tomados singularmente não se mostra regular como na média, já que se registram em alguns casos "idas e vindas" que manifestam a dinamicidade do processo de aquisição da qual falamos antes. Entretanto, a tendência ao desenvolvimento é confirmada.

Podemos, portanto, inferir dos dados que durante o percurso aumentou a familiaridade dos alunos com a língua. Eles passaram a escrever de forma cada vez mais autônoma, reduziram as interrupções e conseguiram utilizar a língua estrangeira para expressar suas idéias. Como dissemos nas páginas anteriores, a maior fluência pode indicar também que os alunos tenham automatizado certas estruturas e aprendido a usar mais fórmulas fixas. Isso pode levar a resultados positivos na comunicação, que precisam, porém, ser confirmados pela comparação 
com outros dados, pois apenas os valores da fluência não dizem se a um maior número de palavras em cada T-unit corresponde também uma maior expressividade, isto é, uma redação em que o aluno consegue "dizer bem" o que pensa e pretende dizer.

Uma primeira comparação deve ser feita com os dados relativos à complexidade sintática, cujos valores médios são representados em nossos gráficos por uma curva ascendente muito parecida com a da fluência. Em particular, os valores resultantes da aplicação da proporção orações/T-unit $(C / T)$ e orações subordinadas/T-unit $(D C / T)$ aumentam de modo gradual e mostram uma relativa linearidade, embora o crescimento maior se observe entre o segundo e o terceiro semestre e - após um intervalo - no último. Na realidade, nessa fase intermediária os resultados médios continuam subindo, mas de forma mais "suave", indicando uma momentânea estabilização.

Uma comparação entre dados gerais e dados individuais mostra que, no caso da complexidade, não há muitas diferenças dignas de atenção. Registram-se alguns raros casos de alunos que seguem individualmente um percurso diferente em relação à média geral, mas pode-se afirmar que todos mostram um crescimento constante e que a maioria (sete alunos de dez) chega ao valor mais elevado no último semestre.

Os resultados sugerem então que os alunos escrevem com um maior número de subordinadas à medida que avançam em seu percurso de aquisição/aprendizagem da língua estrangeira. Precisamos, porém, relembrar que escolhemos a subordinação como indicador de uma tendência. Isso significa que o aumento desse dado nos permite inferir que, ao longo do 
processo, os alunos se apropriam de estruturas mais complexas e se tornam capazes de escolher a maneira mais adequada de expressar-se.

Como afirma Skehan, a complexidade em textos de aprendizes implica perceber "uma vontade de correr riscos, de tentar novas formas mesmo que elas possam não ser completamente corretas." $"$ Por isso, um elevado índice de complexidade é certamente um sinal de "ousadia" nas redações em língua estrangeira, por meio do qual o aprendiz mostra que sabe reestruturar e dominar as possibilidades sintáticas da língua que está aprendendo e, portanto, exprimir e comunicar idéias de forma cada vez mais eficaz.

Esse primeiro cotejo entre os dados relativos à fluência e à complexidade confirma que identificamos uma tendência: as redações analisadas revelam o desejo de autonomia e a vontade de experimentar a língua. Através das estruturas que escolhem em suas redações, os aprendizes manifestam um desenvolvimento na dimensão expressiva e mostram que querem dizer e que têm "algo a dizer".

Passemos agora à variação lexical. Para essa medida observa-se também um progresso, mas - contrariamente ao que observamos para a fluência e para a complexidade - os valores crescem rapidamente até o terceiro semestre, mostram mais um pequeno aumento no quarto semestre e, a partir disso, evidenciam um retrocesso.

95 "A willingness to take risks, to try out new forms even though they may not be completely correct" (SKEHAN, 1998: 5). 
Cabe ressaltar que a queda não é substancial e poderia ser avaliada mais como uma forma de estabilização do que como retrocesso real. De fato, a análise dos dados pode levar a afirmar que os alunos, após alcançar elevados níveis de variação lexical logo nos primeiros semestres, permanecem praticamente no mesmo patamar.

Também os dados individuais, embora mostrem como sempre um maior número de "idas e vindas" e manifestem de forma mais clara o quão irregular é o percurso de aprendizagem de uma língua estrangeira, revelam que oito de dez alunos estão no valor máximo da variação lexical entre o terceiro e o quarto semestre, confirmando as indicações dadas pela média geral, já que a queda no quinto e no sexto semestre não é significativa e em nenhum caso os valores descem até um nível inferior ao registrado no terceiro e no quarto semestre.

Soma-se assim à evolução da fluência e da complexidade também uma tendência ao aumento da variação lexical, essencial para confirmar que as produções se movem em direção à maior expressividade. Os valores sobem e indicam a presença de uma propensão a privilegiar o sentido em relação à forma e a utilizar os instrumentos lingüísticos disponíveis para alcançar esse objetivo.

Além disso, esses dados permitem avançar a hipótese de que a interlíngua desses discentes tenha se estendido ao máximo, no sentido de que, em todos os momentos de seu percurso, a motivação e o desejo de escrever e de expressar as próprias idéias os tenha levado a utilizar até estruturas lingüísticas ainda não sedimentadas. De fato, ao crescimento de fluência, complexidade e variação lexical não corresponde um aumento da precisão que seja comparável em termos de regularidade. 
Embora, em geral, os textos analisados possam ser considerados bastante corretos (há mediamente 1,36 erros por T-unit), a média geral da precisão é a que mais evidencia irregularidades, que se tornam ainda mais evidentes, se olharmos os resultados individuais reproduzidos nos gráficos da Figura 3 (p. 231) em que a repentina descontinuidade ilustra a nãolinearidade do sistema complexo que é o da língua (cf. LARSEN-FrEEMAN, 2006: 592).

Mas vejamos primeiro como se desenvolve a linha que representa a precisão média, isto é, o número total de agramaticalidades por T-unit em todos os alunos (E/T). Observando-a percebemos que no segundo semestre o resultado piora em relação ao primeiro semestre e que, após uma melhora no terceiro e um pico positivo no quarto semestre, no quinto e no sexto semestre os valores voltam a piorar.

O que temos aqui é provavelmente a manifestação da instabilidade da aquisição/aprendizagem da língua estrangeira que pode originar o desenvolvimento da precisão em forma de U que mencionamos no capítulo anterior ${ }^{96}$. Acontece que a um estágio de precisão inicial segue uma queda, depois da qual há um aumento e mais uma queda e assim por diante. A explicação para esse fenômeno é a reestruturação do sistema interlingüístico, que é causada pela chegada de novas estruturas, as quais, antes de ser incorporada, criam uma alteração de todo o sistema e podem fazer registrar um maior número de agramaticalidades.

\footnotetext{
${ }^{96}$ Descrevemos o fenômeno na nota 75 deste trabalho, onde fizemos referência ao artigo de McLaughlin (1990), no qual é explicada essa hipótese hoje muito conhecida e citada.
} 
Entretanto, é importante ressaltar que a maior precisão registrada no momento inicial do percurso é, na verdade, apenas aparente. Parece precisão, mas não o é, pois se trata somente do resultado de um restrito repertório de formas aprendidas no início do percurso, que o aluno consegue "controlar". Essas formas não são "analisadas" pelo aprendiz, mas sim decoradas como se fossem lexemas ou sintagmas fixos, que não requerem, portanto, conhecimento das estruturas e do funcionamento da língua e permitem a produção de pequenos textos que não apresentam agramaticalidades.

Além disso, no caso dos textos que estamos analisando aqui, há mais um fator que deve ser considerado: os alunos estavam escrevendo um texto a partir de um outro texto e no primeiro semestre, ainda inseguros na língua estrangeira, mantiveram-se muito próximos do texto de partida, o que contribuiu para que evitassem de escrever formas agramaticais.

O consistente aumento no número de agramaticalidades que se verifica no segundo semestre é a demonstração do que estamos afirmando. Quando os estudantes começam a aprender mais sobre a língua e seu funcionamento e quando principiam a diferenciar entre estruturas regulares e irregulares, aparecem as agramaticalidades. Aquilo que no início se apresentava como precisão não dependia da estruturação cuidadosa de um sistema subjacente e, por isso, desmorona, assim que chegam as novas estruturas lingüísticas e que os aprendizes começam a criar um verdadeiro sistema.

A nova queda do quinto e do sexto semestre pode representar mais um momento de instabilidade ao qual seguiria provavelmente um novo aumento se a linha continuasse, isto é, se o curso tivesse uma duração maior. 
Mais uma observação interessante diz respeito aos três níveis de erros. Não surpreende que a maior parte dos erros se concentre no segundo nível, pois esses são, em sua maioria, erros morfossintáticos e, portanto, aqueles que os alunos cometem porque estão provavelmente testando hipóteses (conscientes ou inconscientes) sobre a língua estrangeira. De fato, se considerarmos a interlíngua como sistema autônomo em desenvolvimento, precisamos observá-la e estudá-la não apenas considerando o que contém de "errado", mas também o que os erros indicam sobre o processo de aprendizagem, transformando assim nossa maneira de olhar as produções dos aprendizes. As agramaticalidades podem sinalizar movimentos do aprendiz que, embora não tenha ainda alcançado a "correção", está caminhando em direção à língua alvo.

Cabe sublinhar também que os erros "leves" (de primeiro nível) e - em medida ainda maior - os erros "graves" (de terceiro nível) diminuem até chegar quase a zero, indicando que aumenta por parte dos alunos o grau de apropriação da língua e a sensibilidade em relação às possibilidades e às impossibilidades de seu sistema.

Uma última reflexão sobre os resultados da nossa avaliação da competência lingüística dos aprendizes concerne às relações entre a precisão e os outros critérios adotados, em especial a fluência e a complexidade. Há, com efeito, quem afirme que uma maior complexidade ou uma maior fluência poderiam afetar a precisão e que, portanto, geralmente produções mais fluentes e complexas seriam menos corretas (cf. entre outros SKEHAN, 1998: 5). Os nossos dados não confirmaram isso e não mostraram uma ligação direta entre os valores de fluência, complexidade ou variação lexical e a precisão. 
Vimos que fluência e complexidade manifestaram uma forte interdependência e que a variação lexical também revelou algumas analogias com as outras duas medidas. Ao contrário, a média geral da precisão e, mais ainda, os dados individuais dos aprendizes não evidenciaram nenhuma relação com os outros valores e seguiram um percurso aparentemente independente, mostrando que os recursos lingüísticos de cada indivíduo são transformados de maneira única por meio do uso.

\subsection{AVALIAÇÃo DA COMPETÊNCIA DISCURSIVA}

Para a avaliação da competência discursiva não pudemos obviamente servir-nos de medidas quantitativas tão precisas e testadas quanto aquelas utilizadas para a análise do desenvolvimento lingüístico e da progressão na aquisição/aprendizagem da língua estrangeira.

Decidimos, portanto, partir da definição de competência discursiva adotada neste trabalho e operar com alguns dos principais conceitos utilizados na elaboração das atividades didáticas, observando mais detidamente como cada aluno tratou - ao longo dos seis semestres e nas seis redações - a temporalização, a espacialização e a actorialização. Além disso, buscamos verificar como se desenvolveram suas observações em relação aos efeitos de sentido e se e como eles conseguiram perceber relações no interior dos textos que estavam analisando.

De fato, como vimos no capítulo 2, o trabalho realizado em sala de aula teve durante todo o curso a finalidade de estimular a reflexão sobre o sentido dos textos, o funcionamento da língua e 
a funcionalidade discursiva dos fatos gramaticais. Por meio de atividades didáticas dirigidas procuramos criar um percurso que pudesse desenvolver a sensibilidade em relação a uma leitura que apreendesse, de maneira cada vez mais fina, os sentidos do texto. Para esse fim utilizamos os princípios da semiótica que nos permitiram dispor de um instrumental metodológico preciso e criar material pedagógico específico para incentivar leituras cada vez mais autônomas e produtivas, "guiando" a visão e a escuta dos aprendizes em busca de relações nos textos e dirigindo-os para que "notassem" a maneira como são organizados.

Observaremos agora como se manifesta a competência discursiva nos textos dos alunos. Em especial, em nossa observação, relacionaremos os pontos principais das atividades didáticas de base e as produções dos alunos, com o objetivo de perceber se e em que medida as indicações fornecidas nas questões escritas foram seguidas pelos aprendizes e se e em que medida foram transformadas em considerações pertinentes e produtivas sobre o texto literário a analisar.

É importante relembrar que não pedíamos aos alunos que elaborassem um texto que reproduzisse exatamente o que havia sido discutido em sala de aula, nem que seguisse uma a uma as questões contidas nas atividades didáticas. Ao contrário, para a elaboração da tarefa indicávamos aos alunos que utilizassem as atividades didáticas como base para escrever seu próprio texto de análise. Observando as relações entre as instruções dadas e as redações dos discentes, teremos, portanto, um indicador expressivo do "efeito" do trabalho realizado, pois partimos do pressuposto de que entrou nos textos dos alunos apenas aquilo que eles conseguiram “absorver" e que lhes pareceu significativo. 
Como já dissemos, dedicaremos atenção especial às categorias de tempo, espaço e pessoa, pois se trata dos três elementos básicos da discursivização, que se apresentam de formas diferentes dependendo de como são utilizadas nos textos as debreagens, isto é, se os textos se configuram mais como textos enunciativos (em que aparece um eu, um aqui e um agora) ou enuncivos (em que aparece um ele, um algures/alhures e um então), produzindo efeitos de sentido de subjetividade e de objetividade. Na discursivização, empregam-se também embreagens, ou seja, neutralizam-se as oposições presentes nas categorias de tempo, espaço e pessoa, o que significa que se utiliza um tempo por outro, um marcador de espaço por outro, uma pessoa por outra, com vistas a criar determinados efeitos de sentido. Ademais, pode-se considerar o ponto de vista de um observador sobre as categorias da enunciação, que as aspectualiza. Tudo isso fez parte das aulas e das reflexões sobre os textos literários e é por isso que tentaremos recuperar esses elementos nas redações dos alunos para verificar o que "aconteceu" ao longo do processo de aprendizagem.

Comecemos pelas atividades didáticas relativas ao conto Luca non dimentica, analisado no primeiro semestre, e tentemos concentrar-nos em primeiro lugar na questão do tempo, que um dos pontos questionava diretamente. Pedimos que os alunos identificassem e transcrevessem todas as expressões referentes ao tempo contidas no texto e que procurassem perceber seus "efeitos". 97

\footnotetext{
97 Relembramos que nas atividades didáticas procuramos não mencionar exatamente os elementos lingüísticos específicos que deviam ser procurados, para deixar que os alunos pudessem escolher sobre quais aspectos concentrar sua atenção. Portanto, a questão da temporalização é introduzida por uma genérica pergunta sobre o "tempo" no texto, pedindo que os alunos busquem não só os elementos específicos que o professor já identificou, mas tudo o que lhes parece relevante para a interpretação do texto.
} 
Embora a pergunta tenha sido respondida e discutida em sala de aula, lendo as produções dos alunos, percebemos que eles notaram, em geral, apenas o tempo físico e não descreveram o tempo lingüístico explicitamente. Na maior parte dos casos recontam o enredo do texto proposto, identificando o antes e o depois, mas não se aprofundam em questões de organização textual e não usam a metalinguagem gramatical ou a dos elementos teóricos de análise discursiva.

Em apenas um caso um aluno identifica os tempos verbais utilizados sem, contudo, tentar uma análise de seus efeitos de sentido. Eis o que escreve:

c'è una contraposicione com preterito imperfeito e presente. [Há uma contraposição entre pretérito imperfeito e presente.] (G1) $)^{98}$

utilizando, como vemos, a metalinguagem gramatical do português.

Ainda nessa mesma redação e em outras duas (I1 e J1) podemos observar, no entanto, que, embora imprecisas, aparecem citações do efeito aspectual de aceleração produzido pelo aparecimento no conto do "tempo do relógio":

Le espressioni riferite al tempo provocano l'effetto che il tempo passa [...] [As expressões que se referem ao tempo provocam o efeito de que o tempo passa [...] ] (G1)

Nel testo ha exprissioni riferite al tempo che provocano l'effetto di fuga di tempo. [No texto há expressões relativas ao tempo que provocam o efeito de fuga do tempo.] (I1)

Le espressioni provocano un effeto di apressamento del destino. [As expressões provocam um efeito de apressamento do destino.] (J1)

\footnotetext{
${ }^{98}$ Note-se que as análises dos alunos serão sempre citadas sem alterações. A tradução foi realizada procurando respeitar ao máximo os textos de partida e é de nossa autoria.
} 
Somente essas três das dez produções analisadas incluem observações sobre alguns dos efeitos de sentido ligados ao tempo criados a partir da construção do conto, mas isso basta para concluir que o debate sobre o texto acontecido em sala de aula começou desde o início a estimular leituras e interpretações.

Perguntamos sobre o aparecimento no texto do discurso direto (debreagem enunciativa de segundo grau) e pedimos aos alunos que dissessem qual o efeito de sentido produzido por essa escolha do enunciador. Cinco dos dez discentes escreveram sobre esse efeito de sentido e mencionaram, ainda que com incertezas na formulação, a "ilusão" de estar ouvindo alguém que fala, a realidade e até o efeito de sentido de aproximação. Vejamos o que dizem os alunos:

Quando leggiamo il racconto, il discorso direto all'inizio del testo crea un effetto di vicinanza, crea le ilusione che siamo di fronte della persona che parla. [Quando lemos o conto, o discurso direto no início do texto cria um efeito de aproximação, cria a ilusão de que estamos diante da pessoa que fala.] (A1)

Il discorso diretto compare nel testo tre volte e questo crea l'effetto di realtà, di verità. $[\mathrm{O}$ discurso direto aparece três vezes e isso cria o efeito de realidade, de verdade.] (D1)

Il discurso diretto crea un effeto di illusione della realtá. [O discurso direto cria un efeito de ilusão da realidade.] (G1)

Altro effetto che ha nel testo è che stamo di fronte con persone che parla. Questo crea effetto di realità, che l'autore fa utilizzando la strategia del discorso direto. [Outro efeito que há no texto é que estamos diante da pessoa que fala. Isso cria um efeito de realidade, que o autor faz utilizando a estratégia do discurso direto.] (I1)

Il discorso diretto crea l'illusione della realità. [O discurso direto cria a ilusão da realidade.] (J1)

Entretanto, com exceção das redações e dos aspectos citados, na maior parte dos casos a produção escrita dos alunos acabou sendo pouco mais do que uma paráfrase e uma "redução" do conto original, com poucas ou nenhuma observação pessoal e com poucas tentativas de análise. 
Sem dúvida, nesse momento ainda muito inicial do percurso, os aprendizes careciam não só dos instrumentos de análise para poder analisar e interpretar o texto, mas também da segurança na língua estrangeira, na qual estavam ainda dando os primeiros passos. Não surpreende, portanto, observar a falta de "ousadia" por parte da maioria, que se limitou a reproduzir e citar partes do conto de partida e não para justificar uma interpretação ou uma leitura pessoal, mas para "re-contar" permanecendo somente no enredo, embora as atividades em sala de aula tivessem já procurado explorar aspectos do texto relativos principalmente às categorias de tempo e pessoa.

É interessante também observar como nesse momento se manifestam os estilos cognitivos e as diferenças individuais: há, de fato, desde alunos como aqueles que citamos antes que, sem preocupar-se com a possibilidade de "errar", tentam interpretações e se expõem, até discentes que preferem evitar o "erro" e por isso não se distanciam do enunciado do texto de partida.

Já a partir do segundo semestre a maior parte dos alunos manifesta os primeiros sinais de uma transformação. As redações foram escritas a partir do poema Ha partorito de Giorgio Manacorda e, como em todos os outros casos, após a análise realizada em sala de aula.

Percebe-se que os aprendizes começam a conquistar seu espaço e a construir sua autonomia tanto lingüística quanto de análise. Estão apropriando-se de conhecimentos da língua estrangeira e de alguns - embora ainda limitados - instrumentos de análise e isso se manifesta em produções 
escritas mais fluentes e distanciadas do texto de partida, nas quais identificamos a presença das primeiras leituras pessoais e percebemos que as "formas" começam a fazer sentido.

Lendo as formulações escolhidas nas respostas, nota-se que a pergunta sobre o tema do poema é aproveitada para procurar relações e recorrências no texto e entender como se constrói a significação. Os alunos mencionam a contraposição entre nascimento e morte e entre masculino e feminino; falam de abandono e separação e até de indiferença. Entretanto, embora houvesse uma questão direta que indagava deles a respeito dos elementos do texto a partir dos quais havia sido identificado o tema, em geral, os discentes não explicitaram seu movimento de busca, indicando apenas o resultado:

È possibile dire che il tema principale sia la nascita e la morte.[É possível dizer que o tema principal é o nascimento e a morte.] (A2)

Dopo da seconda lettura possiamo osservare che la poesia "parla" dell'abbandono, della separazione, della differenza del universo maschile e femminile. [Após a segunda leitura podemos observar que a poesia "fala" do abandono, da separação, da diferença do universo masculino e feminino.] (C2)

Il tema principale mi sembra essere l'universo maschile contro l'universo feminile, per ché la poesia parla di un uomo che è partirto doppo che una donna, probabilmente, sua moglie, ha partorito. [O tema principal parece-me ser o universo masculino contra o universo feminino, porque o poema fala de um homem que partiu depois que uma mulher, provavelmente sua esposa, deu à luz.] (D2)

Ormai il tema principale è l'amore tra due persone ed il rapporto non corrisposto. Il tema è anche l'indifferenza con l'amore e con le cose della vita. [Ora, o tema principal é o amor entre duas pessoas e a relação não correspondida. $\mathrm{O}$ tema é também a indiferença para com o amor e as coisas da vida.] (E2)

A desiluzione amorosa, nascita e separazione sembra essere il tema princiapale di questa poesia. [A decepção amorosa, o nascimento e a separação parece ser o tema principal desse poema.] (G2) 
Contudo, é interessante notar que é provavelmente a partir dessa leitura à procura de relações que praticamente todos os alunos fizeram referência desde o início à ironia e ao efeito de humor que o poema produz. Também nesse caso, a afirmação não é sempre adequadamente motivada, mas muitos percebem a ironia criada a partir do jogo com o duplo sentido do verbo andare contido nas três ocorrências de discurso direto (Come va?/Non c'è male. Come è andata?/ $\grave{E}$ andata/via. Come va?/Va.) e comentam esse aspecto do texto, como no caso do aluno C, que escreve:

Tutta la poesia ha un tono ironico. Quando l'amico domanda Come è andata?, il "io" gioca sul doppio significato del verbo "andare", È andata / via. Il verbo "andare" può essere usato come nel verso sono andato all'ospedale o come nel verso Come è andata? Il primo caso indica movimento e il secondo caso può essere sostituito per "Come stai?" [Todo o poema tem um tom irónico. Quando o amigo pergunta "Como foi?", o "eu" joga com o duplo significado do verbo "ir", "Foi /embora". O verbo "ir" pode ser usado como no verso "fui ao hospital" ou como no verso "Como foi?" O primeiro caso indica movimento e o segundo caso pode ser substituído por “Como está?”] (C2)

Refina-se também a reflexão sobre o tempo e os discentes, guiados pelas indicações das atividades didáticas, em que eram mencionados os planos temporais do presente e do passado contidos no texto, incluíram em suas análises observações sobre o tempo lingüístico para além das implicações disso nos "fatos" contados. Ainda não aparece a metalinguagem gramatical específica, mas nota-se que os tempos verbais foram adequadamente reconhecidos e que os discentes tentaram pôr esse aspecto em relação com outras características do poema, esboçando hipóteses sobre a funcionalidade discursiva da gramática e sobre a contraposição entre o então enuncivo da "narração" e o agora enunciativo do discurso direto e do último verso. Observe-se o que escrevem, por exemplo, os alunos B e C: 
I risposti sono ironici, l'io poetico gioca con il doppio significato del verbo andare ("Come è andata", nel senso di sentimento e "É andata via", nel senso di movimento), usa anche il doppio gioco dei due piani temporali del presente e del passato (ho lasciato anche lei/ parto alle sei). [As respostas são irónicas, o eu poético joga com o duplo significado do verbo "ir" ("Como foi", no sentido de sentimento e "Foi embora", no sentido de movimento), utiliza também o duplo jogo dos dois planos temporais do presente e do passado (deixei ela também/parto às seis).] (B2)

Lui usa diversi stratagemmi nella poesia per creare l'effeto di umore, come per esempio il doppio giocco dei due piani temporali, passato e presente, come nei versi Ma ho lasciato anche lei / parto alle sei. [Ele usa diversas estratégias no poema para criar o efeito de humor, como, por exemplo, o duplo jogo dos dois planos temporais, passado e presente, como nos versos Mas deixei ela também / parto às seis.] (C2)

Nas atividades didáticas foi dedicado espaço também à questão da pessoa e havia perguntas sobre atores e enunciador. Os alunos procuraram, portanto, observar no poema elementos significativos por meio dos quais se pudesse entender como os atores se manifestavam e como ia delineando-se a "imagem" do enunciador. Foi prevista - como no primeiro semestre - uma questão específica sobre a função do discurso direto à qual responderam desta vez sete dos dez discentes (A, D, E, F, G, I e H). Alguns deles, além de observar o efeito de sentido de realidade e de aproximação, procuraram também pôr as debreagens enunciativas de segundo grau em relação com a organização da temporalidade e da actorialidade do texto como fazem, por exemplo, estes alunos:

C'è tre attori nella poesia. L'io, che é un uomo, lei (la donna) e un'altra persona che parla due volte con l'io. Nel primo dialogo, l'io domanda lei come sta. Nel secondo dialogo, l'altra persona parla con l'io di lei. Nel scorso dialogo, l'altra persona domanda l'io come sta. Il discorso diretto provoca l'effetto di realtà, di che le cose sono sucessi. [Há três atores no poema. $\mathrm{O}$ eu, que é um homem, ela (a mulher) e uma outra pessoa que fala duas vezes com o eu. No primeiro diálogo, o eu pergunta como ela está. No segundo diálogo, a outra pessoa fala com o eu dela. No último diálogo, a outra pessoa pergunta ao eu como está. O discurso direto provoca o efeito de realidade, que as coisas aconteceram.] (D2)

L'enunciatore, quando decide di introdurre il discorso diretto, crea un effetto di realtà, come se questo può succedere veramente, nella vita reale. Crea anche, un effetto di prossimità con il lettore, che così, può capisce meglio sul che cosa si dice nella poesia. [O enunciador, quando decide introduzir o discurso direto, cria um efeito de realidade, como se 
isso pudesse acontecer de verdade, na vida real. Cria também um efeito de aproximação com o leitor, que, assim, pode entender melhor o que se diz no poema.] (F2)

Tutti i verbi sono usatti nella forma passata, però nei dialoghi sono usatti anche $i$ verbi nel presente. Questo stratagemma crea l'effetto della realtà ed aprossima il lettore della situazione narrata. Anche il discorso diretto aiuta nell'effetto della realtà. [Todos os verbos são utilizados no passado, mas nos diálogos são utilizados também verbos no presente. Esse recurso cria o efeito de realidade e aproxima o leitor da situação narrada. Também o discurso direto ajuda no efeito de realidade.] (J2)

Nas redações do terceiro semestre há uma evidente transformação. Vê-se que os alunos estão realizando um movimento em direção a uma maior independência lingüística e interpretativa e que começam, portanto, a produzir análises mais autônomas. O texto a partir do qual foram escritas as redações desse semestre é o conto intitulado Occhi di Paola.

Cabe observar que há uma correspondência entre a maior complexidade presente nas redações e as atividades didáticas relativas a esse texto, que foram planejadas e elaboradas prevendo que, nesse momento de seu percurso, os alunos poderiam ter êxito na realização de uma "tarefa" mais elaborada, que exigia deles uma "participação interpretativa" maior e habilidades lingüísticas mais sofisticadas, tanto na recepção quanto na produção em língua estrangeira.

Embora cada texto seja desenvolvido de maneira diferente, há interessantes recorrências evidentemente advindas das indicações didáticas utilizadas como roteiro para a elaboração da redação de análise. Isso mostra que os trabalhos em grupo e os debates realizados em sala de aula produziram "efeitos" mais visíveis. De fato, podemos pressupor que as questões propostas foram incorporadas às análises escritas pelos alunos porque foram "absorvidas", o que não havia ainda acontecido nos outros dois semestres. 
Observemos, por exemplo, o tratamento dado à categoria do tempo. No conto em pauta a temporalidade possuía um papel significativo e ocupou, portanto, um lugar central nas atividades didáticas. Isso se refletiu nos trabalhos dos alunos, que escreveram sobre suas estruturas organizadoras, mostrando que perceberam a funcionalidade discursiva e o alcance desses mecanismos para a construção do sentido do texto.

Uma primeira observação a que todos dedicaram atenção concerne à função do presente do indicativo utilizado pelo enunciador como tempo principal da narração. Como evidenciam os exemplos a seguir, os alunos avançaram hipóteses sobre os possíveis efeitos de sentido que essa escolha produz e buscaram explicar suas implicações:

Il narratore è un osservatore che vede e narra, lui usa il presente e sembra che include il lettore usando questo tempo verbale. Questa è una strategia dell'enunciatore per costruire l'effetto di senso della veritá e dell'oggettività nel testo. [O narrador é um observador que vê e narra, ele usa o presente e parece incluir o leitor usando esse tempo verbal. Essa é uma estratégia do enunciador para construir o efeito de sentido de verdade e de objetividade no texto.] (C3)

È usato nel testo, come tempo verbale principale, il presente che causa la concomitanza tra il momento in cui si parla con il momento di cui si parla, tra il momento dell'enunciazione e il momento dell'avvenimento. Quest'uso crea l'effetto di avicinamento, di realtà. [É utilizado no texto, como tempo verbal principal, o presente, que causa a concomitância entre o momento em que se fala e o momento de que se fala, entre o momento da enunciação e o momento do acontecimento. Esse uso cria o efeito de aproximação, de realidade.] (D3)

Il racconto è narrato in terza persona, com un narratore onisciente, che si uttilizza principalmente del tempo presente. Questo crea nel lettore la sensazione di che il narratore è un osservatore di tutto quello che succede, e il tempo presente crea l'illusione di simultaneità, come se il narratore raccontasse in presenza. [O conto é narrado em terceira pessoa, com um narrador onisciente, que utiliza principalmente o tempo presente. Isso cria no leitor a sensação que o narrador é um observador de tudo que acontece e o tempo presente cria a ilusão de simultaneidade, como se o narrador contasse em presença.] (F3)

L'uso del presente crea anche un effetto di simultanità (il narratore sembra essere un osservatore della scena che include il lettore alla storia, perché è come se il lettore vedesse la scena insieme al narratore). [O uso do presente cria também um efeito de simultaneidade (o narrador parece ser um observador da cena que inclui o leitor na história, porque é como se o leitor visse a cena junto com o narrador).] (I3) 
Em alguns casos, há referências também a um diferente uso do presente do indicativo, que aparece como presente gnômico no momento em que é citado um pensamento do ator do enunciado, mas sem que as aspas delimitem seu espaço em relação ao narrador, cuja voz se mistura, portanto, à voz dele. O presente do indicativo assume aqui uma função relevante e é notável que os alunos tenham incluído em suas análises essa reflexão:

C'è un momento nel testo in cui l'enunciatore interrompe la narrazione ed inserisce, senza usare le virgolette, un pensiero di Duccio, cosicchè la battuta del personaggio si confonde con quella dell'enunciatore. In questa frase il narratore parla al presente onnitemporale. [Há um momento no texto em que o enunciador interrompe a narração e insere, sem usar as aspas, um pensamento de Duccio, de modo que a fala da personagem se confunde com a do enunciador. Nessa frase o narrador fala no presente omnitemporal.] (C3)

C'è anche un unico caso di uso del presente gnomico o onnitemporale. Ocorre nel pensiero di Duccio: "Dunque, è così che vanno le cose, pensò, al risveglio: nessun rimorso, nulla cambia. Si può tradire e farla franca, anche con se stessi. Si può tranquillamente convivere con i propri peccati.". Quest'uso causa l'effetto di verità indiscutibile, di che non si pùo discordare di quel che è detto. [Há também um único caso de uso do presente gnômico ou omnitemporal. Ocorre no pensamento de Duccio: "É assim, então, que são as coisas, pensou, ao acordar: nenhum remorso, nada muda. Pode-se trair e não ser punido, nem por si mesmo. Pode-se tranqüilamente conviver con os próprios pecados.". Esse uso causa o efeito de verdade indiscutível, de que não se pode discordar do que é falado.] (D3)

Com uma única exceção, em todas as produções dos aprendizes aparecem também observações sobre a relação entre os tempos verbais passato prossimo e passato remoto e sua centralidade para a interpretação do texto. Selecionamos três alunos e reproduzimos a seguir os trechos das redações em que eles expõem suas considerações sobre esse aspecto do texto:

Il tempo verbale usato nella narrazione è il presente, però vengono usati anche il passato remoto e il passato prossimo creando un gioco tra il tempo di riferimento e il tempo della narrazione. Cosi quando il narratore usa il passato remoto riguardando al tradimento, il suo obiettivo è di allontanare quello che è successo in relazione al momento dell'enunciazione.("Il pomeriggio in cui tradi Paola") [O tempo verbal utilizado na narração é o presente, mas são usados também o passato remoto e o passato prossimo criando um 
jogo entre o tempo de referência e o tempo da narração. Assim quando o narrador usa o passato remoto falando da traição, seu objetivo é afastar aquilo que aconteceu em relação ao momento da enunciação. ("A tarde em que traiu Paola")] (A3)

L'enunciatore usa anche due tempi del passato, che sono molto importanti in questo testo perchè aiutano a spiegare quello che Duccio pensa del tradimento. Quando l'enunciatore usa il passato remoto - che è il tempo della storia - per raccontare un'azione, lui si riferisce ad un'azione "lontana" e che non è più rilevante per il presente. Lui usa questo tempo nel frammento in cui racconta il tradimento. Ma quando l'enunciatore usa il passato prossimo - che è il tempo direttamente legato al momento dell'enunciazione - significa che quello che il personaggio dice, è rilevante per il presente. Lui usa questo tempo nel frammento in cui Duccio parla del tradimento: "Non l'ha più fatto". [O enunciador usa também dois tempos do passado, que são muito importantes nesse texto porque ajudam a explicar o que Duccio pensa da traição. Quando o enunciador usa o passato remoto - que é o tempo da história - para contar uma ação, ele se refere a uma ação "distante" e que não é mais relevante para o presente. Ele usa esse tempo no fragmento em que conta a traição. Mas quando o enunciador usa o passato prossimo - que é o tempo diretamente ligado ao momento da enunciação - significa que aquilo que a personagem diz, é relevante para o presente. Ele usa esse tempo no fragmento em que Duccio fala da traição: "Non l'ha più fatto".] (C3)

Ci sono altre due tempi verbali nel testo: il passato prossimo e il passato remoto. Il passato remoto è meno frequente è è usato da raccontare le cose che sono successe quando Duccio ha tradito Paola, vent'anni fa. Così, allontana il fato del tradimento e crea l'effetto di non essere rilevante al presente e che deve essere dimenticato, mentre il passato prossimo è usato da raccontare le cose che sono rilevante al presente come o fato di cui non l'ha più tradito. [Há outros dois tempos verbais no texto: o passato prossimo e o passato remoto. $\mathrm{O}$ passato remoto é menos freqüente e é usado para contar as coisas que aconteceram quando Duccio traiu Paola, há vinte anos. Assimì, afasta o fato da traição e cria o efeito de que não é relevante para o presente e de que deve ser esquecida, enquanto o passato prossimo é usado para contar as coisas que são relevantes para o presente como o fato de que nunca mais a traiu.] (D3)

Pode-se perceber que as observações sobre a alternância dos dois tempos perfectivos do passado são bastante articuladas: os discentes citam o momento de referência, o momento do acontecimento e o momento da enunciação e são estabelecidas relações entre eles para que se expliquem seus efeitos de sentido. Assim, embora às vezes possam ainda ser constatadas algumas imprecisões, os alunos demonstram saber utilizar com boa propriedade tanto a metalinguagem gramatical do italiano quanto a da semiótica, o que havia sido apenas esboçado nos semestres anteriores. 
Nota-se, além disso, que os discentes foram capazes de apresentar as características da temporalidade em sua relação com outros componentes do texto e que, enquanto descreviam os fatos gramaticais, também lhes atribuíam sentidos. Na construção da argumentação aparecem, com efeito, outras instâncias importantes para a estruturação do texto e para a criação do sentido como os atores e o narrador, que são descritos em sua relação com os fatos narrados.

É mencionado nesse contexto também o enunciador. Citá-lo e analisar como se manifestam suas escolhas no enunciado significa ter consciência das relações entre enunciado e enunciação e saber que há uma instância por trás de todos os textos, um $e u$ que existe mesmo quando não diz $e u$.

Há mais um aspecto do conto que chamou a atenção dos discentes e que, portanto, está presente em quase todas as redações. Trata-se da catáfora que introduz o ator do enunciado: aparece, de fato, primeiro um predicado conjugado na terceira pessoa do singular, mas sem um sujeito explícito e depois um pronome direto masculino que indica um ator do enunciado do qual, no início do conto, ainda não se sabe nada. Foi prevista nas atividades didáticas uma pergunta específica sobre isso, mas merece atenção o fato de que oito dos dez alunos escreveram sobre a questão, acrescentando sempre observações relativas aos efeitos de sentido de suspense e à modalização pelo querer saber que isso cria. Reproduzimos abaixo alguns exemplos:

La narrazione è fatta in terza persona, il protagonista ci è presentato cataforicamente. All'inizio sappiamo pure che è un uomo dall'uso del pronome "lo" in "Qualcosa lo tormenta" alla prima riga. Questo stratagemma insieme ad altri elementi creano un'impressione di attesa, trattene il lettore. [A narração é feita em terceira pessoa, o protagonista nos é apresentado cataforicamente. No início sabemos também que é um homem pelo uso do 
pronome "o" em "Algo o atormenta" da primeira linha. Essa estratégia em conjunto com outros elementos cria uma impressão de espera, segura o leitor.] (A3)

L'inizio del testo è molto interessante, giacchè il protagonista, Duccio, è presentato cataforicamente attraverso l'uso del pronome diretto atono lo. Non si sa perchè lui non puó dormire e che cosa lo tormenta. Questo crea anche un effetto di curiosità ed aspettativa che trattiene il lettore e lo fa continuare a leggere. [O início do texto é muito interessante, pois o protagonista, Duccio, é apresentado cataforicamente por meio do uso do pronome direto "o". Não se sabe porque ele não pode dormir e o que o atormenta. Isso cria também um efeito de curiosidade e expectativa que segura o leitor e o faz continuar na leitura.] (C3)

L'uso della catafora, che permette soltanto nello sviluppo del testo sapersi che c'è un "lui" del quale si parla, è anche un ricorso per creare un clima di suspense e un sentimento di curiosità nell lettore. [O uso da catáfora, que permite somente no desenvolvimento do texto saber que há um "ele" do qual se fala, é também um recurso para criar um clima di suspense e un sentimento di curiosidade no leitor.] (E3)

Il protagonista maschile è introdotto cataforicamente con "lo" tormenta per creare l'effetto di curiosità e di attesa nel lettore. Questo è un stratagemma che permette un'anticipazione di elementi che non sono stati ancora citati. [O protagonista masculino é introduzido cataforicamente por meio de "lo" atormenta para criar o efeito de curiosidade e de espera no leitor. Essa é uma estratégia que permite uma antecipação de elementos que ainda não foram citados.] (G3)

Il racconto inizia con la frase: "Non può dormire", non si sa chi è la persona di chi si parla, $i$ dettagli sono rivelati a poco a poco, questo crea un effetto di sospense che si mantiene dell'inizio alle fine del racconto. [ O conto começa com a frase: "Não pode dormir", não se sabe quem é a pessoa da qual se fala, os detalhes são revelados pouco a pouco, isso cria um efeito di suspense que se mantém do início até o final do conto.] (H3)

Um último ponto que vale a pena ressaltar concerne às oposições presentes no texto que se revelam por meio da figurativização cromática, que rege uma composição de elementos contrapostos, que os alunos foram chamados a observar e comentar. O resultado foi uma elaboração, em alguns casos bastante produtiva, que, pondo em relação os elementos eufóricos e disfóricos contidos no texto, interpretou sua função no interior dele e a maneira como contribuíam para a criação do sentido como acontece no exemplo seguinte:

Si può osservare anche l'opposizione tra i colori (azzurro e grigio) che compare all'inizio e alla fine del racconto riguardando gli occhi di Paola. Gli occhi compaiono nel testo come elemento centrale che collegato con le altre parole chiave come rimorso e peccato, creano un gioco tra l'oscurità e il chiarore. Questo gioco è presente in tutto il racconto. All'oscurità 
si può collegare la colpa, il rimorso, il colore grigio degli occhi, l'incertezza, la possibilità della punizione, il pentimento, l'incubo, tra altre cose e al chiarore si può collegare il sogno, la concienza tranquilla, l'innocenza, ecc. All'inizio i colori (azzurro e grigio) creano un'opposizione tra vecchiaia e gioventù e alla fine questi colori rappresentano l'opposizione tra la certezza e il dubbio. [Pode-se observar também a oposição entre as cores (azul e cinza) que aparece no início e no final do conto e diz respeito aos olhos de Paola. Os olhos aparecem no texto como elemento central que, ligado a outras palavras chave como remorso e pecado, cria um jogo entre escuridão e claridade. Esse jogo está presente em todo o conto. À escuridão pode-se relacionar a culpa, remorso, cor cinza dos olhos, a incerteza, a possibilidade da punição, o arrependimento, o pesadelo, entre outras coisas e à claridade pode-se ligar o sonho, a consciência tranqüila, a inocência, etc. No início as cores (azul e cinza) criam uma oposição entre velhice e juventude e no final essas cores representam a oposição entre certeza e dúvida.] (A3)

As redações do quarto semestre analisam o poema de Patrizia Cavalli Se ora tu bussassi alla mia porta. Lendo-as percebemos que os alunos elaboraram textos nos quais há evidências de interpretações pessoais e sinais da capacidade de utilizar autonomamente as reflexões feitas em sala de aula. De fato, nota-se que todos os textos se referem aos elementos para os quais as atividades didáticas chamaram a atenção e que, portanto, todos repetem argumentações similares, usando-as, porém, de forma diferente para justificar sua própria análise.

Comecemos pelos procedimentos de temporalização, espacialização e actorialização que os alunos levaram em conta em suas redações, observando a maneira como apareciam no texto e as debreagens a partir das quais se organizavam. O primeiro verso do poema contém indícios relevantes sobre isso e uma das questões das atividades didáticas visava a dirigir a atenção dos estudantes para essa característica do texto que foi, de fato, incluída na maior parte de suas análises como nos dois casos a seguir: 
Possiamo osservare già nel primo verso della poesia di Patrizia Cavalli l'importanza degli elementi scelti che ci fanno pensare a vari riferimenti possibili come le persone, lo spazio e la situazione. La poesia comincia con un "Se" che introduce un periodo ipotetico - in questo caso della possibilità - guidando così la nostra lettura. Il verso continua con l'avverbio di tempo "ora" che indica un momento di riferimento presente proiettato in un'ipotesi futura e dopo con sequenza "tu bussassi alla mia porta", in cui appare un "tu" che pressupone un "io", un congiuntivo imperfetto che conferma la seconda persona e dà alla poesia un tono più soggettivo, il possessivo "mia" che esplicita l'io e il sostantivo "porta" che ci dà un'idea di spazio. [Podemos observar já no primeiro verso do poema de Patrizia Cavalli a importância dos elementos escolhidos que nos fazem pensar em várias referências possíveis como as pessoas, o espaço e a situação. A poesia começa com um "Se" que introduz um período hipotético - nesse caso da 'possibilidade' - guiando assim nossa leitura. O verso continua com o advérbio de tempo "agora" que indica um momento de referência presente projetado numa hipótese futura e depois com a seqüência "você batesse à minha porta", em que aparece um "tu" que pressupõe um "eu", um subjuntivo imperfeito que confirma a segunda pessoa e dá ao poema um tom mais subjetivo, o possessivo "minha" que explicita o eu e o substantivo "porta" que nos dá uma idéia de espaço.] (C4)

Osservando atentamente il primo verso, possiamo trovare molti elementi interessanti: c'è l'uso del pronome "tu"; se esiste un tu che ascolta, esiste anche un io che parla. Quest'uso esplicita la persona, che é rafforzata dall'uso del pronome possessivo "mia". C'è un riferimento alla porta che ci indica lo spazio; l'io è dentro la casa e il tu ne è fuori. C'è anche un riferimento al tempo con l'uso dell'avverbio "ora". [Observando atentamente o primeiro verso, podemos encontrar muitos elementos interessantes: há o uso do pronome "tu"; se existe um tu que ouve, existe também um eu que fala. Esse uso explicita a pessoa, que é reforçada pelo uso do pronome possessivo "minha". Há uma referência à porta que nos indica o espaço; o eu está no interior da casa e o tu está fora dela. Há também uma referência ao tempo com o uso do advérbio "agora".] (D4)

Note-se que o primeiro desses dois exemplos já menciona um elemento essencial para a leitura do texto: o período hipotético. De sua presença no poema e de suas implicações para a estruturação e a leitura falam todas as análises dos alunos. Eles perceberam que à prótase e à apódose do período hipotético correspondem as duas seqüências em que pode ser dividido o poema; notaram que a primeira é uma condição, enquanto a outra é uma conseqüência; escreveram de que tipo de período hipotético se trata e que tempos e modos verbais são utilizados (congiuntivo imperfetto-condizionale presente); fizeram também suposições relativas aos efeitos que poderiam advir dessa escolha: 
Dopo aver letto gli altri versi è possibile dire che la poesia può essere divisa in due parti a partire della congiunzione "Se": la protasi, che costituisce la condizione e l'apodosi che, invece, è la conseguenza di questa condizione. [Depois da leitura dos outros versos é possível dizer que o poema pode ser dividido em duas partes a partir da conjunção "Se": a prótase, que constitui a condição e a apódose que, ao contrário, é a conseqüência dessa condição.] (C4)

Il poema comincia con un "Se", l'unica parola scritta con la maiuscola nel poema e questo indica l'uso del periodo ipotetico della possibilità. Il periodo ipotetico in questo caso, può essere diviso in due parti: la prima è la protasi, che presenta una condizione, la seconda si chiama apodosi e costituisce una conseguenza. Il primo verso "Se ora tu bussassi alla mia porta", presenta un avvenimento proiettato verso un'ipotesi futura. [O poema começa com um "Se", a única palavra escrita com a maiúscula no poema e isso indica o uso do período hipotético da possibilidade. O período hipotético nesse caso, pode ser dividido em duas partes: a primeira é a prótase, que apresenta uma condição, a segunda chama-se apódose e constitui uma conseqüência. O primeiro verso "Se ora tu bussassi alla mia porta", apresenta um acontecimento projetado em direção a uma hipótese futura.] (F4)

La scelta di usare il periodo ipotetico mette in evidenza il tema del poema che è l'impossibilità dell'amore nel piano dell'arte (sia nella poesia sia nel pezzo di teatro). [A escolha de utilizar o período hipotético põe em evidência o tema do poema que é a impossibilidade do amor no plano da arte (tanto na poesia quanto na peça de teatro).] (G4)

Contribuem para a construção da temporalidade do poema os advérbios de tempo "ora"

(agora) e "poi" (depois). O segundo advérbio, por estar em relação com o dêitico "ora”, tem um

valor enunciativo e, portanto, ambos são atualizados todas as vezes em que são lidos:

L'altra osservazione importante é che l'avverbio "ora" presentifica il testo, in una contemporaneità con il lettore, mentre il "poi" rappresenta un momento successivo rispetto al momento dell'enunciazione, e questa successione viene rafforzata dalla congiunzione "e". [Outra observação importante é que o advérbio "agora" presentifica o texto, numa contemporaneidade com o leitor, enquanto o "depois" representa um momento posterior em relação ao momento da enunciação e essa sucessão é reforçada pela conjunção "e".] (E4)

I due avverbi di tempo "ora" e "poi" inseriscono nella poesia un legame con il momento di riferimento temporale presente, l'enunciazionalità, però questo "ora" non è effettivo visto che è in un periodo ipotetico. "Poi" indica una successione temporale confermata da "ora" e una continuità delle azioni ipotetiche che è anche enfatizzata dal connettivo "e". L'uso del connettivo " $e$ " nel secondo, terzo, quarto verso crea un effetto di attesa nel lettore che è eliminato dal "senza" e pois ripreso dall" "e" nel sesto verso quando culmina nel discorso diretto. [Os dois advérbios de tempo "agora" e "depois" inserem no poema uma ligação com o momento de referência temporal presente, a enunciatividade; todavia, esse "agora" não é efetivo visto que está num período hipotético. "Depois" indica uma sucessão temporal confirmada pelo "agora" e uma continuidade das ações hipotéticas que é também enfatizada pelo conectivo "e". O uso do conectivo "e" no segundo, terceiro, quarto verso cria um efeito 
de espera no leitor que é eliminado pelo "sem" e depois retomado pelo "e" no sexto verso quando culmina no discurso direto.] (G4)

Em seguida, propusemos nas atividades didáticas um aprofundamento da reflexão sobre actorialidade e espacialidade e pedimos aos alunos que observassem no texto por meio de quais elementos se manifestavam e a que conclusões era possível chegar após perceber esses elementos. Registram-se assim comentários sobre a relação entre o eu e o tu e sobre sua indeterminação, como nos exemplos a seguir:

Non si sa chi è l'io o il tu, non si riesce a sapere come sono, se chi parla è un uomo o una donna, sembra però che tra loro c'è un rapporto affettivo e l'io dipende dal tu, già che tutte le azioni sono praticate dal tu. [Não se sabe quem é o eu ou o tu, não se consegue saber como são, se quem fala é um homem ou uma mulher, parece, contudo, que entre eles existe uma relação afetiva e que o eu depende do tu, já que todas as ações são praticadas pelo tu.] (D4)

Gli elementi della persona e dello spazio non definiscono con chiarezza chi parla con chi, e questa è una caratteristica del genere poetico, ossia, creare un'immagine universale con diverse possibilità di interpretazione. [Os elementos da pessoa e do espaço não definem com clareza quem fala com quem, e essa é uma característica do gênero poético, isto é, criar uma imagem universal com diferentes possibilidades de interpretação.] (E4)

Há ainda reflexões sobre a espacialidade, cuja importância no poema contribui para a produção do sentido. A esse respeito era essencial que os alunos percebessem o valor metonímico das figuras "porta" e "bocca", que convocam respectivamente a casa e o corpo e separam o espaço de dentro, o espaço íntimo do eu e o espaço de fora, o espaço do outro:

La porta e la bocca simboleggiando uno spazio domestico e dell'intimità riguardano un movimento da fuori a dentro la vita dell'io. [A porta e a boca simbolizando um espaço doméstico e da intimidade dizem respeito a um movimento de fora para dentro da vida do eu.] (A4)

Ci sono molti riferimenti allo spazio e possiamo dividerlo in due: lo spazio della casa e lo spazio del corpo. Lo spazio della casa viene esplicitato attraverso la porta e ci indica dove è l'io. Lo spazio del corpo viene esplicitato attraverso la bocca ed oltre al rapporto tra $i$ personaggi ("e poi tu entrassi dentro la mia bocca"), mostra una relazione con la porta 
della casa: attraverso la porta, si riesce a entrare dentro la casa ed attraverso la bocca si riesce a entrare dentro il corpo, che è lo spazio più intimo. [Há muitas referências ao espaço e podemos dividi-lo em dois: o espaço da casa e o espaço do corpo. O espaço da casa é explicitado por meio da porta e nos indica onde está o eu. O espaço do corpo é explicitado por meio da boca e, além da relação entre as personagens ("e depois você entrasse dentro da minha boca"), mostra uma relação com a porta da casa: através da porta, consegue-se entrar dentro da casa e através da boca consegue-se entrar dentro do corpo, que é o espaço mais íntimo.] (D4)

A corporalidade explicitada pela figura da "boca" permeia todo o texto, embora seja muitas vezes mencionada indiretamente. A pergunta que foi formulada com o objetivo de fazer refletir sobre esse aspecto do texto produziu resultados e aparece em todos os textos dos alunos, como nos dois exemplos que reproduzimos a seguir:

Infine l'uso delle immagini di diverse parti del corpo umano ha un senso particolare di rapporto amoroso e erotismo. Per esempio, "bussare" rimanda a mano e dita. "Occhiali" rappresenta gli occhi, la visione del mondo, il tipo di rapporto. "Bocca" è quella parte usata per bere, baciare, parlare, e con la possibilità di "entrare" come dice il verso, dimostra uno spazio corporale e intimo. [Para concluir, o uso das imagens de diferentes partes do corpo humano possuem um sentido especial de relacionamento amoroso e erotismo. Por exemplo, "bater (à porta)" remete a mão e dedos. "Óculos" representa os olhos, a visão do mundo, o tipo de relacionamento. "Boca" é a parte do corpo utilizada para beber, beijar, falar e com a possibilidade de "entrar", como diz o verso, demonstra um espaço corporal e íntimo.] (E4)

Il poema è pieno di immagini che rimandano ai sensi umani come il tatto, il gusto, l'udito, e alle parti del corpo, che vengono suscitate attraverso i verbi e qualche sostantivo, come "bussare" e "togliere", per esempio, che rimandano alle mani; gli "occhiali" che rimandano agli occhi; la "bocca" che viene citata esplicitamente, ecc. Questo suggerisce al lettore l'idea di un amore carnale, vissuto prima di una possibile separazione. [O poema é cheio de imagens que remetem aos sentidos como o tato, o paladar, a audição, e às partes do corpo, que são evocadas por meio dos verbos e de alguns substantivos, como "bater (à porta)" e "tirar", por exemplo, que remetem às mãos; os "óculos" que remetem aos olhos; a "boca" que é citada explicitamente, etc. Isso sugere ao leitor a idéia de um amor carnal, vivido antes de uma possível separação.] (F4) 
Chegamos ao quinto semestre e ao quinto texto analisado que foi o conto L'onorevole doppia chance. Nas atividades didáticas há perguntas parecidas às dos semestres anteriores e há paralelamente a introdução de novos conceitos de análise, que podem produzir nesse texto específico reflexões geradoras de sentidos nem sempre evidentes.

Relembramos que a repetição da estrutura geral das atividades didáticas, além de certas perguntas específicas, fazia parte da nossa proposta pedagógica, pois, como já dissemos, acreditamos que conhecer a estrutura pode ajudar os aprendizes a concentrar-se mais na elaboração da "tarefa".

No caso desse conto iniciamos o trabalho de análise pedindo aos alunos que procurassem as iterações sêmicas no texto e tentassem, a partir disso, descobrir as isotopias presentes e definir o tema do texto. Todos perceberam que as recorrências do texto apontavam para a relação entre máfia e política e que o ator do enunciado reunia ambas as esferas temáticas. Vejamos o que escreve o aluno B:

I temi del racconto sono la politica e la mafia, ma non solo. Possiamo osservare dalle scelte lessicali dell'autore che compare nel testo il tema dei mass midia e, dietro tutto questo, la questione del doppio. La parola del titolo, "onorevole", è quella che scatena tutti questi temi. Da una parte significa deputato, dall'altra, viene dalla parola "onore", il che ci fa ricordare la mafia, a causa degli "uomini d'onore". [Os temas do conto são a política e a máfia, mas não só isso. Podemos observar, a partir das escolhas lexicais do autor, que aparece no texto o tema da mídia e, por trás de tudo isso, a questão do duplo. A palavra do título, "onorevole", é a que desencadeia todos esses temas. Por um lado, significa deputado, por outro, deriva da palavra "honra", o que nos faz lembrar da máfia, por causa dos "uomini d'onore".] (B5)

É interessante constatar que o aluno percebe a centralidade do lexema onorevole, que aparece tanto no título, quanto num passo em discurso direto presente no corpo do texto e possui 
uma função-chave no conto porque age como conector de isotopias, unindo o âmbito temático da máfia e o da política. Além disso, é a partir dos dois sentidos desse lexema que se reforça a isotopia do duplo, essencial para entender todo o texto, pois, na realidade, atravessa os outros campos temáticos e ajuda a entendê-los. Escolhemos mais alguns exemplos que, de formas diferentes, se referem a essas questões:

Dopo aver analizzato il racconto è possibile notare che il tema del doppio si manifesta in diversi modi, attraverso il protagonista, la voce del narratore, lo spazio, nelle isotopie e persino le scelte temporali dell'enunciatore. [Após analisar o conto é possível notar que o tema do duplo se manifesta de diferentes formas, através do protagonista, da voz do narrador, do espaço, das isotopias e até das escolhas temporais do enunciador.] (C5)

Una delle cose più palese ed interessante del racconto è la questione del doppio, che c'è inizio nel proprio titolo ed è presente in tutto il testo, dalla struttura alla vita dei personaggi. [Uma das coisas mais evidentes e interessantes do conto é a questão do duplo, que começa no próprio título e está presente em todo o texto, desde a estrutura até a vida das personagens.] (F5)

Nel titolo si vede la parola "doppia" vicino alla parola "onorevole" e questo collegamento fa venire in mente che l'onorevole ha qualcosa di doppio. Anche la parola "onorevole" ha qualcosa doppia perché fa riferimento alla professione del politico, ma fa anche pensare all'onore che riguarda il mondo della mafia. [ No título vê-se a palavra "doppia" ao lado da palavra "onorevole" e essa ligação me faz vir à mente que o "onorevole" tem algo duplo. Também a palavra "onorevole" possui algo duplo porque faz referência à profissão do político, mas faz pensar também na honra que concerne ao mundo da máfia.] (I5)

As atividades didáticas visavam a deixar mais espaço aos discentes e, portanto, perguntavam sem muitas especificações sobre pessoa, tempo e espaço. O objetivo era deixar que eles observassem com mais autonomia os elementos contidos no conto, buscando perceber como se organizavam essas três categorias. Nas interpretações dos alunos foi sempre mencionado o duplo, percebido pelos alunos como elemento central a partir do qual se constrói o texto. 
Para o espaço foram fornecidas indicações que guiavam mais claramente em direção à duplicidade. Com efeito, na formulação dessa parte da atividade evidenciou-se a divisão em dois do espaço no texto: por um lado, há a televisão e, por outro, o hotel e em ambos está o onorevole “duplicado", ator principal do enunciado.

Quest'ultimo tema, la doppia vita dell'onorevole, è rafforzato dal modo in cui l'autore costruisce il testo. La doppia vita del protagonista è rappresentata nel testo concretamente, atraverso lo spazio, anche lui, doppio: da un lato abbiamo l'albergo, dov'è l'onorevole. Dall'altro, la TV, dove lui parla con i giornalisti, facendo finta di essere onesto. E lui si vede in $T V$, poi si ascolta in una radio. [Esse último tema, a dupla vida do onorevole, é reforçado pela maneira como o autor constrói o texto. A dupla vida do protagonista é representada no texto concretamente, através do espaço, este também duplo: por um lado, temos o hotel, onde o onorevole está. Pelo outro, a TV, onde ele fala com os jornalistas, fingindo ser honesto. E ele se vê na TV, depois se ouve numa rádio.] (B5)

Rispetto alla spazializzazione che si riferisce allo spazio obiettivo dell'enunciato abbiamo l'albergo e la TV ed anche questi rappresentano il doppio. Nella stanza dell'albergo lui si vede e si ascolta, in TV risponde alle domande dei giornalisti; nella stanza lui usa una cravatta rossa, in TV ne usa una nera; nel corridoio dell'albergo lui viene sparato mentre in $T V$ sta rispondendo che teme di più per le sorti dei valori che rappresenta. [A respeito da espacialização que se refere ao espaço objetivo do enunciado temos o hotel e a TV e eles também representam o duplo. No quarto do hotel ele se vê e se ouve, na TV responde às perguntas dos jornalistas; no quarto ele usa uma gravata vermelha, na TV usa uma preta; no corredor do hotel atiram nele enquanto na TV está respondendo que teme mais pela sorte dos valores que representa.] (C5)

La questione dello spazio è molto importante per lo sviluppo dell'idea centrale del racconto, ossia, le cose doppie. Ci sono due spazi principali: la TV e la stanza di un albergo. Così c'è un uomo fisicamente vero nella stanza che osserva la sua immagine in TV [...] [A questão do espaço é muito importante para o desenvolvimento da idéia central do conto, isto é, as coisas duplas. Há dois espaços principais: a TV e o quarto de um hotel. Assim há um homem fisicamente verdadeiro no quarto que observa sua imagem na TV [...] (E5)

Na opinião de alguns discentes também a vagueza que caracteriza a introdução do tempo do conto corrobora a idéia de duplicidade. De fato, o uso de gerúndio e infinitivo, que possibilitam uma narração na qual não é necessário explicitar a pessoa e fixar momentos de referência ou de acontecimento, faz parte dessa sutil organização do conto na qual esses elementos possuem uma função para o sentido do todo. Os alunos notaram também que esse caráter duplo é ainda 
reforçado pela presença de verbos reflexivos de percepção, nos quais o sujeito é quem faz a ação, cujo efeito recai sobre ele mesmo:

[...] l'infinito e il gerundio, che rafforzano il carattere doppio del testo giacché possono creare ambiguità, possono indicare azioni concomitanti come nel frammento sorride ascoltandosi rispondere o possono rappresentare il doppio più simbolicamente con l'uso dei verbi riflessivi. [[...] o infinitivo e o gerúndio, que reforçam o caráter duplo do texto pois podem criar ambigüidade, podem indicar ações concomitantes como no fragmento "sorri ouvindo-se responder" ou podem representar o duplo mais simbolicamente com o uso dos verbos reflexivos.] (C5)

Un altro aspetto che riguarda il doppio è l'uso dei verbi riflessivi come "vedersi" ed "ascoltarsi". È interessante osservare che $i$ verbi riflessivi si riferiscono al personaggio principale e sono verbi senza desinenze diversificate per persona (non "mostrano" la persona alla quale si riferisce l'azione, per questo si potrebbe dire che non c'è in questo testo la vera e propria personalità dell'onorevole, il personaggio non sarebbe una persona determinata). [...] Viene usato anche il gerundio che crea l'effetto del doppio: "sorride ascoltandosi rispondere" può significare sia che sorride mentre si ascolta che sorride perché si ascolta. [Outro aspecto que diz respeito ao duplo é o uso dos verbos reflexivos como "veder-se" e "ascoltar-se". É interessante observar que os verbos reflexivos se referem à personagem principal e são verbos sem desinências diversificadas por pessoa (não "mostram" a pessoa à qual se refere a ação, por isso se poderia dizer que não há nesse texto a verdadeira personalidade do onorevole, a personagem não seria uma pessoa determinada). [...] É usado também o gerúndio que cria o efeito do duplo: "sorri ouvindo-se responder" pode significar tanto que sorri enquanto se ouve, quanto que sorri porque se ouve.] (I5)

Antes de passar ao sexto semestre, mencionamos uma última característica desse conto, que

foi notada por todos e também se inclui na isotopia do duplo. Trata-se da introdução catafórica do ator do enunciado que da indeterminação vai em direção a uma determinação cada vez maior.

Il nome del protagonista non viene detto. Lui è introdotto nel testo in modo cataforico. [O nome do protagonista não é dito. Ele é introduzido no texto de forma catáforica.] (B5)

Dal punto di vista dell'attorilizzazzione, possiamo osservare che il personaggio principale, l'onorevole, viene introdotto in una prima volta attraverso un verbo in terza persona (risponde) e poi, attraverso l'uso del pronome "lui" nella terza riga e poi appare la parola che lo descrive "onorevole". [Do ponto de vista da actorialização, podemos observar que a personagem principal, o onorevole, é introduzida uma primeira vez por meio de um verbo em terceira pessoa ('responde') e depois, por meio do uso do pronome "ele" na terceira linha e depois aparece a palavra que o descreve "onorevole".] (D5) 
Il personaggio attraverso il quale il testo mostra il tema della mafia viene presentato con un tono di mistero. La prima cosa che fa riferimento al protagonista è un verbo all'infinito. Poi c'è un pronome: lui. Soltanto alla quarta riga si sa una cosa un pò più concreta sul protagonista, che è il suo ruolo sociale. Questo stratagemma atraverso il quale si va dal più indeterminato al più determinato è denominato catafora (che annuncia, ma non specifica il personaggio). Questa strategia crea anche il tono di mistero che è molto presente nel testo. [A personagem por meio da qual o texto mostra o tema da máfia é apresentada com um tom de mistério. A primeria coisa que faz referência ao protagonista é um verbo no infinitivo. Depois há um pronome: ele. Somente na quarta linha sabe-se uma coisa um pouco mais concreta sobre o protagonista, que é seu papel social. Esse recurso por meio do qual se vai do mais indeterminado ao mais determinado é denominado catáfora (que anuncia, mas não especifica a personagem). Essa estratégia cria também o tom de mistério que é muito presente no texto.] (I5)

Il protagonista è introdotto in maniera cataforica e graduale. Così, prima c'è un infinito "Buffo essere nella stanza", dopo c'è un verbo alla terza persona singolare "mentre risponde" e nella terza riga appare il pronome personale "lui". La catafora annuncia il personaggio ma non lo specifica e così, piano piano, la sua introduzione va dal vago al determinato, uno stratagemma che ha come obiettivo quello di far crescere l'interesse di chi legge. [O protagonista é introduzido de forma catáforica e gradual. Assim, antes há um infinitivo "Gozado estar no quarto", depois há um verbo na terceira pessoa do singular "enquanto responde" e na terceira linha aparece o pronome pessoal "ele". A catáfora anuncia a personagem, mas não especifica e assim, pouco a pouco, sua introdução vai do vago ao determinado, um recurso que tem como objetivo o de fazer crescer o interesse de quem lê.] (J5)

No sexto e último semestre do curso os textos dos discentes foram elaborados a partir do poema La poesia oggi, escrito por Sebastiano Vassalli. Confirma-se o que foi observado nos semestres anteriores: os alunos ganham cada vez mais familiaridade com o trabalho de análise, com a metalinguagem específica e com uma descrição semiótica do texto na qual se baseia a interpretação e a leitura pessoal. Isso os leva a se distanciar mais do "roteiro" das atividades didáticas e a utilizar os elementos "notados" para construir textos autônomos.

O poema escolhido para esse semestre apresenta uma estrutura complexa que precisa ser observada, pois dá indícios significativos sobre o sentido e a maneira como se manifesta. A segmentação proposta nas atividades didáticas e incluída nos textos de análise por todos os alunos foi pensada para levá-los a perceber a construção e o entrelaçamento entre as categorias, 
sempre na perspectiva de deixar evidentes as relações que constituem a base para entender como nasce o sentido. A divisão em seqüências remete a "universos distintos" que os alunos deviam identificar, dizendo também a partir de quais elementos discursivos esses universos se constituíam. A maior parte das redações começa, portanto, descrevendo as seqüências como fazem estes dois alunos:

Anche se la poesia viene divisa in quattro strofe, si può fare una nuova divisione tematica la cui prima parte, dal primo al sesto verso, corrisponde all'introduzione del tema riguardo la poesia oggi e la funzione del poeta. La seconda parte corrisponde ai luoghi della poesia, dal settimo al quindicesimo verso, a eccezione del decimo, dell'undicesimo e del dodicesimo verso che corrispondono ad una terza parte, la quale possiamo intitolare la poesia classica. All'ultima parte corrisponde l'ultimo verso che tratta l'indifferenza delle persone. [Embora o poema seja dividido em quatro estrofes, pode-se fazer uma nova divisão temática cuja primeira parte, do primeiro ao sexto verso, corresponde à introdução do tema da poesia hoje e a função do poeta. A segunda parte corresponde aos lugares da poesia, do sétimo ao décimo quinto verso, com exceção do décimo, do décimo primeiro e do décimo segundo verso que correspondem a uma terceira parte, que podemos intitular a poesia clássica. À última parte corresponde o último verso que trata da indiferença das pessoas.] (A6)

Le quattro stofe che compongono questa poesia possono essere divise tematicamente in tre parti. Nella prima (dal primo al sesto verso) il poeta introduce il tema in maniera impersonale e dopo parla in prima persona, nella seconda (dal settimo al penultimo verso) dice dov'è la poesia e nell'ultima parte compare un unico verso che sembra staccarsi dagli altri. Possiamo osservare che questa suddivisione riporta ad universi diversi. L'universo della critica letteraria viene inserito attraverso gli elementi della prima parte in cui il poeta parla di persone ovunque che discutono la poesia attorno a "tavole rotonde" e che danno premi, mentre gli universi della poesia classica e della poesia contemporanea vengono inseriti nella parte in cui lui parla del luogo della poesia. [As quatro estrofes que compõem esse poema podem ser divididas tematicamente em três partes. Na primeira (do primeiro ao sexto verso) o poeta introduz o tema de modo impessoal e depois fala em primeira pessoa, na segunda (do sétimo ao penúltimo verso) diz onde está a poesia e na última parte aparece um único verso que parece separar-se dos outros. Podemos observar que essa subdivisão remete a universos distintos. $\mathrm{O}$ universo da crítica literária é inserido por meio dos elementos da primeira parte em que o poeta fala de pessoas em todo lugar que discutem a poesia em volta de "mesas redondas" e que dão prêmios, enquanto os universos da poesia clássica e da poesia contemporânea são inseridos na parte em que ele fala do lugar da poesia.] (C6)

Em seguida, procedem na análise e, acrescentando detalhes sobre tempo, espaço e pessoa procuram indícios, que justifiquem suas leituras e permitam identificar temas e figuras. Há no 
poema uma contraposição entre a indiferença do presente e o ardor do passado que se revela por meio de vários elementos.

Os tempos verbais, os temas, as referências, a sintaxe e os lexemas escolhidos indicam mundos que se opõem e da oposição fazem nascer o sentido, como notou este aluno:

\begin{abstract}
Quando comincia a indicare il luogo della poesia, l'io ci porta all'universo della poesia moderna. "Sta nei grandi magazzini, nei settimanali illustrati, nella pubblicità al cinema, nella face della gente". Quest'ultimo elemento, però, "faccia della gente", apre un taglio nella poesia: la gente vede le famose cortigiane passare dalla saponeta al vinello toscano, all'abito già pronto, ecc, e proprio quando cita le cortigiane, entra nell'universo della poesia classica: il lessico cambia: "instillarono nel cuore del 'poeta' l'Ideale lontano" e la sintassi cambia, avvicinandosi allo stile latineggiante: "milioni morirono o delirando vissero". [Quando comença a indicar o lugar da poesia, o eu nos leva até o universo da poesia moderna. "Está nas lojas de departamento, nas revistas ilustradas, na publicidade no cinema, nos rostos da gente". Esse último elemento, porém, "rosto da gente", abre um corte no poema: as pessoas vêem as famosas cortesãs passar do sabonete ao vinhozinho toscano, ao vestido já pronto, etc, e justamente quando cita as cortesãs entra no universo da poesia clássica: o léxico muda: "instilaram no coração do 'poeta' o Ideal distante" e a sintaxe muda, aproximando-se ao estilo latinizante: "milhões morreram ou delirando viveram".] (B6)
\end{abstract}

Essa divisão que põe em cena também movimento de aproximação e afastamento e que se refere à poesia contemporânea e à poesia clássica pode ser descrita também concentrando-se, descrevendo e analisando separadamente tempo, espaço e pessoa. Há então descrições da temporalização como essas:

Il tempo verbale sul quale è basata la poesia è il presente ma non per caso il passato remoto viene usato dall'autore in due versi. Nella parte in cui lui indica il luogo della poesia possiamo osservare una contrapposizione fra il mondo lontano e il mondo di oggi. Nella maggior parte della poesia il poeta usa il presente e compaiono alcuni elementi enunciazionali che si riattualizzano come l'avverbio di tempo oggi, ma il poeta usa il passato remoto - tempo enunciativo che indica concomitanza a un momento di riferimento, un'allontananza - quando vuole indicare il mondo lontano. [O tempo verbal no qual é baseada a poesia é o presente, mas não é por acaso que o passato remoto é usado pelo autor em dois versos. Na parte em que ele indica o lugar da poesia podemos observar uma contraposição entre o mundo distante e o mundo de hoje. Na maior parte do poema o poeta 
utiliza o presente e aparecem alguns elementos enunciativos que se reatualizam como o advérbio de tempo hoje, mas o poeta usa o passato remoto - tempo enuncivo que indica concomitância a un momento de referência, um afastamento - quando quer indicar o mundo distante.] (C6)

Sono anche interessanti gli elementi del poema che fanno riferimento al tempo, come gli avverbi di tempo "oggi" e "già", l'aggettivo "lontano" ed i tempi verbali usati, che sono: il presente (prima, seconda, terza e quarta strofa), il condizionale (seconda strofa), il passato remoto (terza strofa), il gerundio (terza strofa) e l'infinito (seconda, terza e quarta strofa). Si può dire adesso che nel poema abbiamo l'uso prevalente del tempo presente, che forse, riguarda al mondo contemporaneo e al posto della poesia oggi. Questo però, si contrappone all'uso del passato remoto che riguarda la poesia classica, ispirata negli ideali più lontani e irragiungibili. Altro elemento interessante da osservare è l'uso dell'avverbio di tempo "oggi", che può essere riatualizzato e quindi riguarda tanto l'epoca in cui è stato scritto il poema (1972) siccome $i$ giorni attuali. $\dot{E}$ anche um elemento enunciazionale perché si riferisce all'io che parla. [São também interessantes os elementos do poema que fazem referência ao tempo, como os advérbios de tempo "hoje" e "já", o adjetivo "lontano" e os tempos verbais utilizados, que são: o presente (primeira, segunda, terceira e quarta estrofe), o condizionale (segunda estrofe), o passato remoto (terceira estrofe), o gerúndio (terceira estrofe) e o infinitivo (segunda, terceira e quarta estrofe). Pode-se dizer agora que no poema temos o uso prevalente do tempo presente, que talvez diga respeito ao mundo contemporâneo e ao lugar da poesia hoje. Isso, contudo, se contrapõe ao uso do passato remoto que concerne à poesia clássica, inspirada nos ideais mais distantes e inalcançáveis. Outro elemento interessante de observar é o uso do advérbio de tempo "hoje", que pode ser reatualizado e portanto concerne tanto à época em que foi escrito o poema (1972) quanto aos dias atuais. É também um elemento enunciativo porque se refere ao eu que fala.] (F6)

Ci sono molti avverbi, aggettivi e tempi verbali che si riferiscono al tempo. Nella terza strofa, per fare una contrapposizione tra passato e presente, vengono usati il passato remoto morirono e vissero e l'aggettivo lontano. L'avverbo oggi che fa parte del titolo è uno stratagemma per ritualizzare la poesia tutte le volte che viene letta perché oggi è enunciazionale e, quindi, si riferisce al momento dell'enunciazione. I deitici Oggi e questo paese non vengono determinati, di conseguenza, lasciano interpretazioni varie ai lettori. [Há muitos advérbios, adjetivos e tempos verbais que se referem ao tempo. Na terceira estrofe, para fazer uma contraposição entre passado e presente, são usados o passato remoto morreram e viveram e o adjetivo lontano. O advérbio hoje que pertence ao título é um recurso para reatualizar a poesia todas as vezes que é lida porque hoje é enunciativo e, portanto, se refere ao momento da enunciação. Os dêiticos hoje e esse país não são determinados, por conseguinte, deixam interpretação variadas aos leitores.] (G6)

Notamos a presença de interessantes observações sobre a espacialidade do poema. Eles percebem, entre outras coisas, que o poema não diz o que é a poesia hoje, mas indica onde está. Além disso, há reflexões produtivas sobre a maneira como é apresentado o espaço no início do poema. Vejamos o que dizem os alunos: 
Dopo aver letto questa "metapoesia" possiamo osservare che il poeta non dice infatti cosa è la poesia, ma la indica: Sta nei grandi magazzini, nei settimanali illustrati, / Nella pubblicità al cinema, nelle facce della gente. Ma non lo fa in modo semplice, giacché contrappone il mondo di oggi e il mondo lontano. [Após ler essa "metapoesia" podemos observar que o poeta não diz de fato o que é a poesia, mas indica-a: está nas lojas de departamento, nas revistas ilustradas, / Na publicidade no cinema, nos rostos da gente. Mas não o faz de modo simples, já que contrapõe o mundo de hoje e o mundo distante.] (C6)

In questa poesia ci sono molti riferimenti allo spazio, come ovunque, questo paese, "tavole rotonde", nella prima strofa, che ci fa pensare a un effetto tipo "zoom", in cui passa da una cosa molto generale a un'altra molto especifica. Un altro spazio interessante è il cuore, che sta nel verso dieci, e che sta nella parte in cui si parla della poesia classica. Questa è un'opposizione agli altri spazi che appaiono nella poesia. Il cuore è l'unico spazio in cui non c'è l'idea di commercializzazione. E poi ci sono gli spazi in cui la poesia può essere trovata, come "grandi magazzini", "settimanali illustrati", "pubblicità al cinema", "saponeta", "vinello toscano", "birra", "profumo" e "supermercato". Questi sono gli spazi in cui si fa la commercializzazione della poesia contemporanea. [Nesse poema há muitas referências ao espaço, como em todo lugar, esse país, "mesas redondas", na primeira estrofe, que nos faz pensar num efeito tipo "zoom", em que passa de uma coisa muito geral a outra muito específica. Un outro espaço interessante é o coração, que está no verso dez e que está na parte em que se fala da poesia clássica. Essa é uma oposição aos outros espaços que aparecem no poema. O coração é o único espaço no qual não há a idéia de comercialização. E depois há os espaçosi em que a poesia pode ser encontrada, como "lojas de departamento", "revistas ilustradas", "publicidade no cinema", "sabonete", "vinhozinho toscano", "cerveja", "perfume" e "supermercado". Esses são os espaços em que se faz a comercialização da poesia contemporânea.] (D6)

Gli elementi che si riferiscono allo spazio sono anche interessante da analizzare. Nella prima strofa abbiamo "ovunque", "questo paese", "attorno a "tavole rotonde"; nella seconda strofa: "al cinema", "nei grandi magazzini" e nella "nella facce della gente"; nella terza strofa: "nel cuore del poeta" e nella quarta strofa "entra al supermercato". Dopo aver individuato ognuno di questi elementi si può dire che c'è una specificazione dello spazio, che comincia con "ovunque" e finisce con "entra al supermercato", in una specie di gradazione che va dal maggiore al minore e più specifico spazio. [Os elementos que se referem ao espaço são também interessantes de analisar. Na primeira estrofe temos "em todo lugar", "esse país", "em volta de "mesas redondas"; na segunda estrofe: "ao cinema", "nas lojas de departamento" e "nos rostos da gente"; na terceira estrofe: "no coração do poeta" e na quarta estrofe "entra no supermercado". Após identificar cada um desses elementos, pode-se dizer que há uma especificação do espaço, que começa com "em todo lugar" e termina com "entra no supermercado", numa espécie de gradação que vai do maior ao menor e mais específico espaço.] (F6)

Compaiono alcuni riferimenti allo spazio. Ci sono: "supermercato", "grandi magazzini", "pubblicità", "cinema", "settimanali illustrati". Questi si riferiscono agli spazi del mondo del consumo. Mentre invece ci sono altri elementi: "questo paese", "tavole rotonde", "cuore del poeta". È interessante vedere il movimento dallo spazio generale "questo paese" allo spazio specifico "supermercato". Poco a poco lo spazio viene specificato e delimitato.[Aparecem algumas referências ao espaço. Há: "supermercado", "lojas de departamento", "publicidade", "cinema", "revistas ilustradas". Esses se referem aos espaços 
do mundo do consumo, enquanto há outros elementos: "esse país", "mesas redondas", "coração do poeta". É interessante ver o movimento do espaço geral "esse país" ao espaço específico "supermercado". Pouco a pouco o espaço é especificado e delimitado.] (J6)

Também em relação à pessoa, as redações dos alunos contêm considerações que manifestam sua capacidade de procurar e perceber as relações no interior do texto. Eles descreveram e interpretaram a maneira como aparecem atores e enunciador, procuraram diferenciar as debreagens actoriais enunciativa e enunciva dadas pela alternância entre primeira e terceira pessoa e foram além da simples constatação na busca de possíveis efeitos de sentido:

L'altro elemento importante da osservare è la persona, chi parla e di chi. Nella prima e terza strofa abbiamo l'uso della terza persona; nella seconda strofa appare la prima volta un "io" in "saprei dire" e "io la posso indicare" e nella quarta strofa abbiamo l'ultimo verso che si stacca dagli anteriori perché pare un discorso diretto o una figura di linguaggio. Si può dire che l'uso della terza persona indica un allontanamento, mentre l'uso dell'io indica un avvicinamento di questo "io" del poema verso i lettori. [O outro elemento importante de observar é a pessoa, quem fala e de quem. Na primeira e na terceira estrofe temos o uso da terceira pessoa; na segunda estrofe aparece pela primeira vez um "eu" em "eu saberia dizer" e "eu posso indicá-la" e na quarta estrofe temos o último verso que se separa dos anteriores porque parece um discurso direto ou uma figura de linguagem. Pode-se dizer que o uso da terceira pessoa indica um afastamento, enquanto o uso do eu indica uma aproximação desse "eu" do poema em direção aos leitores.] (F6)

La poesia è predominantemente oggettiva però ci sono due versi in cui è la prima persona chi parla. La terza persona discrive il rapporto degli studiosi con la poesia nella prima strofa. Nella seconda strofa, la persona chi parla è un io che parla del suo rapporto con la poesia. Nelle altre strofe, c'è l'oggettività della terza persona che fa vedere la contrapposizione tra poesia del passato e contemporanea e il rapporto della poesia con il consumismo. [O poema é predominantemente objetivo, mas há dois versos em que é a primeira pessoa que fala. A terceira pessoa descreve a relação dos estudiosos com a poesia na primeira estrofe. Na segunda estrofe, a pessoa que fala é um eu que fala de sua relação com a poesia. Nas outras estrofes, há a objetividade da terceira pessoa que mostra a contraposição entre a poesia do passado e a contemporânea e a relação da poesia com o consumismo.] (G6)

C'è un gioco di persona nella poesia. La prima strofa è in terza persona, così come nella terza e quarta strofe. Però, nella seconda strofa c'è un "io" che viene inserito attraverso il verbo "saprei". Dopo c'è un "io" espresso direttamente "questa sì, io la posso indicare". Questo stratagemma crea l'effetto di senso di soggettività ed opinioni personale. L'alternanza di persona crea l'effetto di avvicinarsi alla poesia e allontanarsi. Alla fine c'è un discorso diretto perché la frase è introdotta da un trattino. E, secondo me, è una maniera di mettere in evidenza l'indiferenza delle persone verso la poesia: "- La gente guarda e tace, entra al supermercato". [Há um jogo de pessoa no poema. A primeira estrofe está na terceira 
pessoa, assim como a terceira e a quarta. Na segunda estrofe há, porém, um "eu" que é inserido por meio do verbo "saberia". Depois há um "eu" expresso diretamente "essa sim, eu posso indicá-la". Esse recurso cria o efeito de sentido de subjetividade e opinião pessoal. A alternância de pessoa cria o efeito de aproximação do poema e afastamento. No final, há um discurso direto porque a frase é introduzida por um travessão. E, na minha opinião, é uma maneira de pôr em evidência a indiferença das pessoas para com a poesia: "- A gente olha e cala, entra no supermercado.”] (J6)

Uma última consideração que merece ser citada é que a maior parte dos alunos foi capaz de perceber a indiferença da qual fala o poema e de mostrar a partir de quais elementos ela se manifesta. Os trechos que reproduzimos demonstram que as leituras e as interpretações foram muito além da simples execução das atividades didáticas dadas, já que seus textos se distanciam das indicações do professor e as aproveitam para fundamentar idéias próprias.

Terminada nossa leitura das redações dos alunos, podemos concluir que elas refletem o percurso de apropriação dos instrumentos de análise e nos permitem observar um movimento em direção a uma cada vez maior independência para "ousar" interpretações autônomas e não discutidas em sala de aula ou para elaborar autonomamente as análises feitas em conjunto.

A aquisição da competência lingüística, especialmente em termos de maior fluência e familiaridade com a língua estrangeira, possibilitou também a produção de textos mais complexos, nos quais fica claro que os aprendizes desenvolveram, em geral, uma sensibilidade em relação aos textos e foram cada vez mais capazes de incluir leituras próprias a partir das indicações dadas pelo professor. 
Cabe ressaltar que, após os primeiros dois semestres nos quais os resultados foram ainda bastante limitados, já no terceiro semestre os alunos souberam mostrar que se haviam apropriado dos instrumentos e da metalinguagem da análise, aprendendo a expressar com uma propriedade cada vez maior opiniões pessoais, sempre comprovando sua validade por meio do próprio texto. Nos semestres seguintes, percebemos uma continuidade nesse movimento em direção à autonomia. Os estudantes perceberam de forma mais refinada as categorias de tempo, espaço e pessoa nos textos, fizeram gradativamente progressos quanto à interpretação dos fatos gramaticais e textuais em perspectiva discursiva e se acostumaram a criar percursos interpretativos para os textos poéticos baseados nas relações e no sentido que nasce delas. 


\section{CONCLUSÕES}

Começamos o presente trabalho expondo nosso ponto de vista sobre a indissociabilidade entre o ensino de língua e o ensino de literatura, sublinhando que consideramos a integração especialmente indispensável para os estudantes de um curso de Letras e acrescentando que acreditamos ser a diluição dessa dicotomia essencial também no ensino das línguas e das literaturas estrangeiras.

De fato, é no período de formação que um estudante de Letras deve desenvolver a capacidade de compreensão e de interpretação, aperfeiçoando sua habilidade de ver e descobrir sentidos a partir dos elementos lingüísticos. Como futuro profissional das Letras ele precisa, ao longo de sua formação, aprender a ter olhos e ouvidos aguçados, que lhe darão uma perspectiva privilegiada na relação com os textos vistos como discursos, que partem da materialidade lingüística para alcançar significações que vão muito além do denotativo e transmitem valores, ideologia, formações históricas, sociais e culturais.

A proposta que apresentamos nesta tese partiu dessas considerações e foi desenvolvida na convicção de que ensinar uma língua estrangeira e a análise de textos poéticos de forma integrada poderia estimular a aprendizagem dos alunos e fornecer-lhe desde o início de seu percurso a possibilidade de um confronto com a "poesia", que é linguagem em sua funcionalidade plena, e, como tal, permite que eles possam aprender a descobrir seus mecanismos para tornar-se menos ingênuos e mais preparados receptores e produtores de textos. 
Como vimos, a experiência que realizamos em sala de aula, utilizando a literatura não como mero pretexto para introduzir a "gramática", mas como ponto de partida para analisar as estruturas organizadoras da língua e os mecanismos a partir dos quais se constrói o sentido, demonstrou-se eficaz e permitiu a ampliação da competência lingüística, por um lado, e das competências (inter)discursiva e (inter)textual, por outro.

O último capítulo mostrou que uma pesquisa atenta pode revelar generalizações interessantes sobre aspectos do uso da língua, que observamos a partir das medidas da fluência, da precisão, da complexidade e da variação lexical, por meio das quais pudemos avaliar tanto a performance lingüística, quanto o desenvolvimento da aquisição/aprendizagem da língua e perceber, que, ao longo dos três anos de curso, se verificou uma evolução na produção escrita dos discentes.

A partir do instrumental de análise da semiótica francesa preparamos e utilizamos material pedagógico específico que guiou o olhar dos aprendizes, levando-os a ler de forma cada vez mais autônoma e produtiva, e permitindo que eles pudessem apreender as relações e, portanto, o sentido dos textos, que, enquanto textos poéticos, ofereceram ao longo do percurso didático estímulos para profícuas reflexões sobre a linguagem e sua complexidade.

A avaliação qualitativa das redações de análise produzidas pelos alunos revelou um aprimoramento na capacidade de ler os textos, de perceber as relações no interior deles e de interpretá-los de forma cada vez mais autônoma. Demonstrou-se dessa maneira que o ensino da língua estrangeira pode ser integrado à análise de textos literários e que a função estética dos textos, suas potencialidades expressivas e sua abertura em relação a múltiplas interpretações 
podem ter nas aulas um papel de estímulo tanto para adquirir a língua estrangeira, quanto para aprender a analisar textos.

Os dados confirmaram assim nossa hipótese de partida, revelando que a língua estrangeira pode ser aprendida sem a necessidade de "preparar" os alunos, utilizando antes textos mais “fáceis" para que depois eles possam entender a literatura.

Terminado o curso, os alunos responderam a um questionário avaliando nosso curso experimental e refletindo sobre como se realizou seu processo de aprendizagem durante os três anos. As perguntas diziam respeito à relação entre as disciplinas de língua e de literatura e foram formuladas assim para que os alunos pudessem dar sua opinião sobre o curso de língua italiana, no qual a análise dos textos literários constituiu o núcleo central de todas as atividades didáticas. Em sua avaliação, os alunos mencionaram a importância de estabelecer relações entre a língua e a literatura, ressaltaram que foi produtivo poder "transferir" conhecimentos entre uma disciplina e outra no lugar de proceder por compartimentos estanques e fizeram referência à gramática da língua como "instrumento" de análise.

Em especial, agora que chegamos às conclusões, gostaria de deixar a palavra aos alunos para que possamos ouvir sua voz. Permito-me, portanto, neste momento usar a primeira pessoa e pedir a eles que falem por mim:

Não fazíamos um curso de língua simultaneamente ao curso de literatura, baseado em memorização de frases prontas, exercícios repetitivos, etc. Pelo contrário: no curso de língua analisávamos também contos, músicas, filmes, e a parte gramatical era dada através de muitas discussões quanto aos seus "comos" e "porquês". Aprendemos a língua fazendo 
perguntas a ela, "desmascarando-a" em muitos pontos, questionando-a em muitos outros [...] eu diria que aprendemos a "tomar consciência" da língua.

As aulas de Língua Italiana foram fundamentais tanto para a compreensão e participação das aulas de Literatura ministradas em italiano quanto para compreensão e análise dos textos originais que nos eram apresentados. À medida que nos exercitávamos nas aulas de Língua Italiana, trabalhando com textos literários (poesia, contos, trechos de livros, etc) e construindo freqüentemente análises desses mesmos textos, as aulas de Literatura e os textos literários abordados tornavam-se cada vez mais claros. Acredito que as aulas de Língua Italiana aperfeiçoaram a minha leitura crítica e aguçaram meus olhos... 


\section{REFERÊNCIAS BIBLIOGRÁFICAS}

ABREU, Márcia (2006). Cultura letrada: literatura e leitura. São Paulo: Editora UNESP.

ADAM, Jean-Michel (1991). Langue et littérature. Analyses pragmatiques et textuelles. Paris: Hachette.

Almeida Filho, José Carlos Paes de \& Schmitz, John Robert (1998). Glossário de Lingüistica Aplicada. Português-Inglês / Inglês-Português. Campinas: Pontes.

Anuário da Faculdade de Filosofia, Ciências e Letras 1934-1935 (1937). São Paulo: Revista dos Tribunaes.

Anuário da Faculdade de Filosofia, Ciências e Letras 1936 (1937a). São Paulo: Faculdade de Filosofia, Ciências e Letras.

Anuário da Faculdade de Filosofia, Ciências e Letras 1937-1938 (1938). São Paulo: Faculdade de Filosofia, Ciências e Letras.

Anuário da Faculdade de Filosofia, Ciências e Letras 1939-1949 (1953). São Paulo: Faculdade de Filosofia, Ciências e Letras, v. I e II.

Anuário da Faculdade de Filosofia, Ciências e Letras 1950 (1952). São Paulo: Faculdade de Filosofia, Ciências e Letras.

Anuário da Faculdade de Filosofia, Ciências e Letras 1951 (1952a). São Paulo: Faculdade de Filosofia, Ciências e Letras.

Anuário da Faculdade de Filosofia, Ciências e Letras 1952 (1954). São Paulo: Faculdade de Filosofia, Ciências e Letras.

Amossy, Ruth (org.) (1999). Images de soi dans le discours. La construction de l'éthos. Lausanne: Delachaux et Niestlé.

(org.) (2005). Imagens de si no discurso. A construção do éthos. Tradução de Dilson Ferreira da Cruz, Fabiana Komesu e Sírio Possenti. São Paulo: Contexto.

AuthIER-ReVuZ, Jacqueline (1982). Hétérogéneité montrée et hétérogéneité constitutive: éléments pour une approche de l'autre dans le discours. Paris: DRLAV 26, p. 91-151.

Campinas: Unicamp, 19 , p. 25-42.

(1990). Heterogeneidade(s) enunciativa(s). Cadernos Lingüísticos.

BAKHTIn, Mickail (1987). A cultura popular na Idade Média e no Renascimento. O contexto de François Rabelais. São Paulo: Hucitec. 
(1988). Marxismo e filosofia da linguagem. São Paulo: Hucitec.

BALBONI, Paolo Emilio (1994). Didattica dell'italiano a stranieri. Roma: Bonacci. (2002). Le sfide di Babele. Turim: UTET. (org.) (1995). Curricolo di italiano per stranieri. Roma: Bonacci. (org.) (1996). Educazione bilingue. Perugia: Guerra Edizioni.

BARKI, Pazit et alii (2003). Valutare e certificare l'italiano di stranieri. I livelli iniziali. Prefácio de Massimo Vedovelli. Perugia: Guerra Edizioni.

BArros, Diana Luz de (1990a). Teoria semiótica do texto. São Paulo: Ática.

(1990b). Paixões e apaixonados: exame semiótico de alguns percursos.

Cruzeiro Semiótico. Porto: Associação Portuguesa de Semiótica, 11-12, p. 60-72.

(2002). Teoria do discurso: fundamentos semióticos. $3^{\text {a }}$ edição. São Paulo: Editora Humanitas/FFLCH/USP.

BARTHES, Roland (1974). O prazer do texto. Tradução de Maria Margarida Barahona. Prefácio de Eduardo Prado Coelho. Lisboa: Edições 70.

Cultrix. (1980). Aula. Tradução e posfácio de Leyla Perrone-Moisés. São Paulo: Mário Laranjeira. $2^{a}$ edição. São Paulo: Martins Fontes.

Benveniste, Émile (1989). Problemas de lingüistica geral II. Tradução de Eduardo Guimarães et alii. Campinas: Pontes.

(2005). Problemas de lingüistica geral I. Tradução de Maria da Glória Novak e Maria Luisa Néri. $5^{\text {a }}$ edição. Campinas: Pontes.

BERARDINELLI, Alfonso (2001). "Le forme della letteratura: ultime tendenze. La poesia." In: Vários autores, Storia della letteratura italiana. Il Novecento: scenari di fine secolo, Milão: Garzanti, p. 152-182.

Roma: Castelvecchi.

\& CoRdelli, Franco (2004). Il pubblico della poesia. Trent'anni dopo.

Bertinetto, Pier Marco (1991). "Il tempo". In: Renzi, Lorenzo \& SAlvi, Giampaolo. Grande grammatica italiana di consultazione. II. I sintagmi verbale, aggettivale, avverbiale. La subordinazione. Bolonha: Il Mulino, p. 13-161.

Bertrand, Denis (2003). Caminhos da semiótica literária. Tradução do Grupo Casa Bauru: Editora da Universidade do Sagrado Coração. 
BetTONi, Camilla (2001). Imparare un'altra lingua. Bari: Laterza.

Bloom, Harold (2001). Como e por que ler. Tradução de José Roberto O’Shea. Rio de Janeiro: Objetiva.

BRAIT, Beth (2000). Língua e literatura: uma falsa dicotomia. Revista da Anpoll, n. 8, p. 187-206. (2001). "Alteridade, dialogismo, heterogeneidade: nem sempre o outro é o mesmo". In: BRAIT, Beth. Estudos enunciativos no Brasil. Histórias e perspectivas. Campinas: Pontes, p. 7-25.

(2003). "Estudos lingüísticos e estudos literários: fronteiras na vida e na arte”. In: Cunha de Freitas, Alice \& FÁtima F. G. DE CASTro DE, Maria (orgs.). Língua e literatura: ensino e pesquisa. São Paulo: Contexto, p. 13-23.

BRumfit, Chistopher \& Johnson, Keith (orgs) (1979). The Communicative Approach to Language Teaching. Oxford: Oxford University Press.

BRUNER, Jerome (1960). The Process of Education, Cambridge: Harvard University Press. (1990). Acts of Meaning. Cambridge: Harvard University Press.

BRUNI, Francesco \& RASO, Tommaso (orgs.) (2002). Manuale dell'italiano professionale. Teoria e didattica. Bolonha: Zanichelli.

BRUNOT, Ferdinand (1936). La pensée et la langue. Paris: Masson.

Bygate, Martin (2001). "Effects of Task Repetition on the Structure and Control of Oral Language". In: BYGATE, Martin; SKeHAN, Peter \& SwaIn, Merrill (orgs.). Researching Pedagogic Tasks. Second Language Learning, Teaching and Testing. Harlow: Pearson Education Limited, p. 23-48.

; SkeHAN, Peter \& SwaIn, Merrill (orgs.) (2001). Researching Pedagogic Tasks. Second Language Learning, Teaching and Testing. Harlow: Pearson Education Limited.

CANDIDO, Antonio (1975) Literatura e sociedade: estudos de teoria e história literária. $4^{\mathrm{a}}$ edição. São Paulo: Editora Nacional.

Cavalli, Patrizia (1992). Poesie (1974-1992). Turim: Einaudi.

Charaudeau, Patrick \& Maingueneau, Dominique (2006). Dicionário de análise do discurso. Coordenação da tradução de Fabiana Komesu. $2^{a}$ edição. São Paulo: Contexto.

CHOMSKy, Noam (1988). Linguaggio e problemi della conoscenza. Bolonha: Il Mulino. (2002). On Nature and Language. Cambridge: Cambridge University Press.

Ciliberti, Anna (1994). Manuale di glottodidattica. Scandicci-Florença: La Nuova Italia. 
COlLIE, Joanne \& SLATER, Stephen (1987). Literature in the Language Classroom. A Resource Book of Ideas and Activities. Cambridge: Cambridge University Press.

CONSElHo DA EUROPA (2001). Quadro europeu comum de referência para as línguas. Aprendizagem, ensino, avaliação. Tradução do inglês de Maria Joana Pimentel do Rosário e Nuno Verdial Soares. Porto/Lisboa: Asa Edições.

CONSIGLIO D'EuROPA (2002). Quadro comune europeo di riferimento per le lingue. Apprendimento, insegnamento, valutazione. Tradução do inglês de Franca Quartapelle e Daniela Bertocchi. Milão: RCS Scuola/Florença: La Nuova Italia.

COSERIU, Eugenio (1982). “Teses sobre o tema 'linguagem e poesia' ”. In: CoseriU, E. O homem e sua linguagem. Estudos de teoria e metodologia lingüística. Tradução de Carlos Alberto da Fonseca e Mário Ferreira. Rio de Janeiro: Presença/São Paulo: Editora da Universidade de São Paulo, p. 145-149.

(1992). Competencia lingüística. Elementos de la teoría del hablar. Versão espanhola de Francisco Meno Blanco. Madri: Editorial Gredos.

(1993). Do sentido da língua e da literatura. Confluência. Revista do Instituto da Língua Portuguesa do Liceu Literário Português. Tradução de Evanildo Bechara. Rio de Janeiro: Edições Lucerna, $n^{\circ}$ 5, $1^{\circ}$ semestre, p. 29-47.

COURTÉS, Joseph (1991). Analyse sémiotique du discours - de l'énoncé à l'énonciation. Paris: Hachette.

CuCCHI, Maurizio (1983). Dizionario della poesia italiana. I poeti di ogni tempo, la metrica, $i$ gruppi e le tendenze. Milão: Mondadori.

Culioli, Antoine (1973). Sur quelques contradictions em linguistique. Communications. Paris, $\mathrm{n}^{\mathrm{o}}$ 20, p. 80-92.

D'Addio Colosimo, Wanda (1996). Tra input e output... c'è di mezzo il mare. Italiano \& Oltre, 11/2, p. 98-103.

DARDANo, Maurizio \& TRIfone, Pietro (1997). La nuova grammatica della lingua italiana. Milão: Zanichelli.

DeKeyser, Robert M. (1998). "Beyond Focus on Form: Cognitive Perspectives on Learning and Practicing Second Language Grammar". In: Doughty, Catherine \& WiLliams, Jessica (orgs.). Focus on Form in Classroom Second Language Acquisition. New York: Cambridge University Press, p. 42-63.

DELORS, Jacques (org.) (1996). Educação: um tesouro a descobrir. Relatório para a UNESCO da Comissão Internacional sobre Educação para o século XXI. Lisboa: UNESCO/Asa Edições.

De MAuro, Tullio (1997). Guida all'uso delle parole. $12^{\mathrm{a}}$ edição. Roma: Editori Riuniti. 
DiscinI, Norma (2003). O estilo nos textos. São Paulo: Contexto. (2005). A comunicação nos textos. São Paulo: Contexto.

DÖRNYEI, Zoltán (2001). Motivation. Teaching and Researching. Edinburgh: Pearson Education Limited.

Doughty, Catherine J. \& Long, Michael H. (orgs.) (2003). The Handbook of Second Language Acquisition. Oxford: Blackwell.

Doughty, Catherine \& Williams, Jessica (orgs.) (1998). Focus on Form in Classroom Second Language Acquisition. New York: Cambridge University Press.

DuboIS, Jean et alii (1993). Dicionário de lingüística. São Paulo: Cultrix.

DuCROT, Oswald (1983). Operateurs argumentatifs et visée argumentative. Cahiers de Linguistique Française, n.5, Actes du $2^{\mathrm{eme}}$ Colloque de Pragmatique de Genève, p. 7-30. (1984). O dizer e o dito. Campinas: Pontes.

DufF, Alan \& MALEY, Alan (1990). Literature. Resource Books for Teachers. Oxford: Oxford University Press.

Dulay, Heidi \& BuRT, Marina (1977). Remarks on Creativity in Language Acquisition. In: BurT, Marina; Dulay, Heidi \& FInOCCHIARO, Mary (orgs.). Viewpoints on English as a Second Language. New York: Regents, p. 95-126.

ECO, Umberto (1979). Lector in fabula. La cooperazione interpretativa nei testi narrativi. Milão: Bompiani.

(1987). Notes sur la sémiotique de la réception. Actes sémiotiques, IX/81, Paris: Institut National de la Langue Française, p. 1-25.

(2002). Sulla letteratura. Milão: Bompiani.

ElLIS, Rod (1989). Are Classroom and Naturalistic Acquisition the same? A Study of the Classroom Acquisition of German Word Order Rules. Studies in Second Language Acquisition, 11 (3), p. 305-328.

Quarterly, 27, p. 91-113.

(1993). The Structural Syllabus and Second Language Acquisition. TESOL (1994). The Study of Second Language Acquisition. Oxford: Oxford University Press.

$\overline{\text { University Press. }}$

(2003). Task-based Language Learning and Teaching. Oxford: Oxford 
University Press.

\& BARKHUIZEN, Gary (2005). Analysing Learner Language. Oxford: Oxford

\& YUAN, Fangyuan (2004). The Effects of Planning on Fluency, Complexity, and Accuracy in Second Language Narrative Writing. Studies in Second Language Acquisition, $26(1)$, p. $59-84$.

FIORIN, José Luiz (1988). A lógica da neutralidade: um caso de aspectualização do ator. Estudos lingüísticos. XVIII Anais de seminários do GEL. Lorena: Prefeitura Municipal de Lorena, p. 348354.

(1992a). Elementos de análise do discurso. $3^{\mathrm{a}}$ edição. São Paulo: Contexto.

(1992b). Algumas considerações sobre o medo e a vergonha. Cruzeiro Semiótico. Porto: Associação Portuguesa de Semiótica, nº 16, p. 55-63.

São Paulo: Ática.

(1996a). As astúcias da enunciação. As categorias de pessoa, espaço e tempo.

(1996b). "O corpo nos estudos de semiótica francesa.” In: SILVA, Ignácio Assis (org.) Corpo e sentido. São Paulo: Editora da UNESP, p. 85-90.

(2007). "A criação dos cursos de Letras no Brasil e as primeiras orientações da pesquisa lingüística universitária”. In: FÁVERO, Leonor Lopes, BASTOS, Neusa Barbosa \& MARQUESI, Sueli Cristina. Língua Portuguesa: pesquisa e ensino. São Paolo: Editora da PUCSP, v. I, p. 93-104.

Floch, Jean Marie (2001). Alguns conceitos fundamentais em Semiótica Geral. Tradução de Analice Dutra Pillar. São Paulo: Série Documentos do Centro de Pesquisas Sociossemiótica.

FonTANILLE, Jacques (1984). Sémiotique e enseignement du français. Langue Française. Vol. $61, \mathrm{n}^{\circ}$ 1, Paris: Larousse.

Forgione, Francesco \& Mondani, Paolo (1993). Oltre la cupola. Massoneria, mafia, politica. Prefazione di Stefano Rodotà. Posfácio de Agostino Cordova. Milão: Rizzoli.

FoтоS, Sandra (1993). Consciousness Raising and Noticing through Focus on Form: Grammar Task Performance versus Formal Instruction. Applied Linguistics, 14 (4), p. 385-403.

Foster, Pauline \& Skehan, Peter (1996). The Influence of Planning and Task Type on Second Language Performance. Studies in Second Language Acquisition, 18, p. 299-323.

Franzoni, Patricia (1992). Nos bastidores da comunicação autêntica. Uma reflexão em lingüistica aplicada. Campinas: Editora da Unicamp.

FREDDI, Giovanni (1994). Glottodidattica. Fondamenti, metodi e tecniche. Turim: UTET.

GASS, Susan (1988). Integrating Research Areas: A Framework for Second Language Studies. Applied Linguistics, 9 (2), p. 198-213. 
Giacalone Ramat, Anna (org.) (2003). Verso l'italiano. Percorsi e strategie di acquisizione. Roma: Carocci.

GIVÓN, Talmy (1993). English Grammar: A Function-based Approach. Filadélfia: John Benjamins Publishing Company.

GonZÁLEZ, Neide T. Maia (1990). "La utilización del texto literario en las clases de lengua extranjera". In: SILVA, Pedro Câncio da (org). Língua, literatura e integração hispanoamericana. Porto Alegre: SEC, Editora da UFRGS, p. 116-123.

Greimas, Algirdas Julien (1970). Du sens. Essais sémiotiques. Paris: Seuil.

(1974). L'énonciation (une posture épistémologique). Significação. Revista Brasileira de Semiótica. São Paulo, 1, p. 9-25.

(1975a). Sobre o sentido: ensaios semióticos. Petrópolis: Vozes.

(org.) (1975b). Ensaios de semiótica poética. Tradução de Heloysa de Lima Dantas. São Paulo: Cultrix/Editora da Universidade de São Paulo.

Blikstein. São Paulo: Cultrix.

(1976). Semântica Estrutural. Tradução de Haquira Osakabe e Izidoro (1983). Du sens II. Essais sémiotiques. Paris: Seuil.

(1987). De l'imperfection. Périgueux: Pierre Fanlac.

et alii. São Paulo: Cultrix.

\& COURTÉS, Joseph (s/d). Dicionário de semiótica. Tradução Alceu Dias Lima

\& COURTÉs, Joseph (1986). Sémiotique. Dictionnaire raisonné de la théorie du langage. Vol. II. Paris: Hachette.

\& Fontanille, Jacques (1993). Semiótica das paixões. Dos estados de coisas

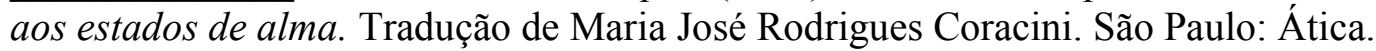

HÉNAUlt, Anne (1994). Le pouvoir comme passion. Paris: Presses Universitaires de France.

Holec, Henri (1981). Autonomy in Foreign Language Learning. Oxford: Oxford University Press.

HuNFELD, Hans (1990). Literatur als Sprachlehre. Ansätze eines hermeneutisch orientierten Fremdsprachenunterrichts. Berlim-Munique: Langenscheidt.

HunT, Kellogg W. (1965). Grammatical Structures Written at Three Grade Levels. Urbana, IL: The National Council od Teachers of English.

(1970). "Recent Measures in Syntactic Development". In: LESTER, M. (org.), Readings in Applied Transformational Grammar. New York: Holt-Rinehart, p. 187-200. 
IMAZU, Maki \& VALERI, Lucilla (2004). Lo sviluppo della sintassi in Italiano L2. Input didattico e abilità di produzione scritta. Siena: Università per Stranieri di Siena.

IZUMI, Shinichi (1999). Testing the Output Hypothesis. Effects of Output on Noticing and Second Language Acquisition. Studies in Second Language Acquisition, 21 (3), p. 421-452.

(2002). Output, Input Enhancement, and the Noticing Hypothesis. An Experimental Study on ESL Relativization. Studies in Second Language Acquisition, 24 (4), p. 541-577.

; Bigelow, Marta; Fujiwara, Miho \& Fearnow, Sarah (1999). Testing the Output Hypothesis. Effects of Output on Noticing and Second Language Acquisition. Studies in Second Language Acquisition, 21, p. 421-452.

JAKOBSON, Roman (1977). Lingüistica e comunicação. Prefácio de Izidoro Blikstein. Tradução de Izidoro Blikstein e José Paulo Paes. São Paulo: Cultrix.

Johnson, Keith \& JoHnson, Helen (orgs.) (1998). Encyclopedic Dictionary of Applied Linguistics. A Handbook for Language Teaching. Oxford: Blackwell Publishing.

KleIN, Wolfgang (1986). Second Language Acquisition. Cambridge: Cambridge University Press.

Learning, 48, p. 527-550.

(1998). The Contribution of Second Language Acquisition Research. Language

Koch, Ingedore V. (1989). A coesão textual. São Paulo: Contexto.

(1997). O texto e a construção do sentido. São Paulo: Contexto.

Krashen, Stephen (1981). Second Language Acquisition and Second Language Learning. Oxford: Pergamon Press.

Pergamon Press.

(1982). Principles and Practice in Second Language Acquisition. Oxford: (1985). The Input Hypothesis. Londres: Longman.

Heinemann.

(2003). Explorations in Language Acquisition and Use. Portsmouth:

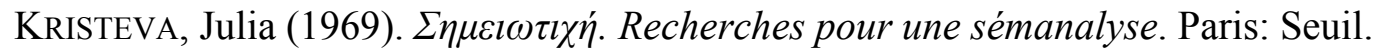

KROLL, Barbara (org.) (1990). Second Language Writing. Research Insights for the Classroom. Cambridge: Cambridge University Press.

Kuiken, Folkert; Mos, Maria \& VedDER, Ineke (2005). Task Complexity and Linguistic Complexity in L2 Writing. International Review of Applied Linguistics, 45 (3), p. 193-211. 
LARSEN-FreEman, Diane (1983). "Assessing Global Second Language Proficiency". In: Seliger, Herbert W. \& Long, Michael H. (orgs.). Classroom-Oriented Research in Second Language Acquisition. Rowley MA: Newbury House, p. 287-304.

(1997). Chaos/Complexity Science and Second Language Acquisition. Applied Linguistics, 18 (2). Oxford: Oxford University Press, p. 141-165

(2006). The Emergence of Complexity, Fluency and Accuracy in the Oral and Written Production of Five Chinese Learners of English. Applied Linguistics, 27 (4), p. 590-619.

\& Long, Michael (1991). An Introduction to Second Language Acquisition Research. Londres: Longman.

LAZAR, Gillian (1993). Literature and Language Teaching. A Guide for Teachers and Trainers. Cambridge: Cambridge University Press.

LEFFA, Vilson J. (1999). O ensino de línguas estrangeiras no contexto nacional. Contexturas, APLIESP, n. 4, p. 13-24.

LENNON, Paul (1991). Error: Some Problems of Definition, Identification and Distinction. Applied Linguistics, 12 (2), p. 180-196.

Lo DuCA, Maria Giuseppa (1990). Creatività e regole. Studio sull'acquisizione della morfologia derivativa dell'italiano. Bolonha: Il Mulino.

(1997). Esperimenti grammaticali. Riflessioni e proposte sull'insegnamento

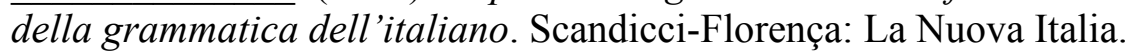

(2003). Lingua italiana ed educazione linguistica. Tra storia, ricerca e didattica. Roma: Carocci.

LONG, Michael H. (1983). Does Second Language Instruction make a Difference? A Review of the Research. TESOL Quarterly, 17, p. 359-382.

(1991). "Focus on Form: A Design Feature in Language Teaching Methodology". In: Bot, Kees de; GinsBerG, Ralph B. \& KrAMSCH, Claire (orgs.). Foreign Language Research in Cross-cultural Perspective. Amsterdã: John Benjamins Publishing Company, p. 39-52.

(1997). Focus on Form on Task-based Language Teaching. Annual McGrawHill Teleconference in Second Language Teaching (http://www.mhhe.com/socscience/foreignlang/top.htm - último acesso em: 25/08/2007).

\& RoBInSON, Peter (1998). "Focus on Form: Theory, Research, and Practice". In: Doughty, Catherine \& Williams, Jessica (orgs.). Focus on Form in Classroom Second Language Acquisition. New York: Cambridge University Press, p. 15-41. 
LONGO, Ilaria (1998). "Natural Approach". In: SERRA Borneto, Carlo (org.). C'era una volta il metodo. Tendenze attuali nella didattica delle lingue straniere. Roma: Carocci, p. 253-266.

LOPES, Edward (1989/1990). Paixões no espelho: sujeito e objeto como investimentos passionais primordiais. Cruzeiro Semiótico. Porto: Associação Portuguesa de Semiótica, $n^{0} 11-12$, p. 154160.

LOPES, Ivã Carlos (2003). Entre expressão e conteúdo: movimentos de expansão e condensação. Itinerários. Araraquara, $\mathrm{n}^{\circ}$ especial, p. 65-75.

Maingueneau, Dominique (1981). Approche de l'énonciation em linguistique française. Paris: Hachette.

(1984). Génèses du discours. Bruxelas: Pierre Mardaga.

(1996a). Pragmática para o discurso literário. Tradução de Marina Appenzeller. São Paulo: Martins Fontes.

(1996b). Elementos de lingüistica para o texto literário. Tradução de Maria Augusta Bastos de Mattos. São Paulo: Martins Fontes.

(1997). Novas tendências em Análise do Discurso. Tradução de Freda

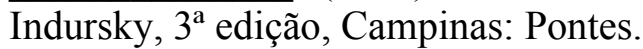

(1999). "Éthos, scenógraphie, incorporation". In: AMOSSY, Ruth (org.). Images de soi dans le discours. La construction de l'éthos. Lausanne: Delachaux et Niestlé, p. 75-100. (2000). Termos-chave da análise do discurso. $1^{\mathrm{a}}$ reimpressão, Belo Horizonte: Editora UFMG.

MANACORDA, Giorgio (1999). Soldato Segreto. Milão: Marcos y Marcos. (2004). La poesia italiana oggi. Un'antologia critica. Roma: Castelvecchi.

MARSCIANI, Francesco (1984). Les parcours passionnels de l'indifference. Actes Sémiotiques, VI, 53. Paris: Institut National de la Langue Française, p. 5-30.

MAurand, Georges \& NAUde, Michel (1987). La sémiotique et le commentaire de texte. Actes Sémiotiques, X, 42. Paris: Institut National de la Langue Française, p. 40-56.

MaZzoleni, Marco (1991). "Ipotetiche e concessive". In: RENZI, Lorenzo \& SALVI, Giampaolo (orgs.). Grande grammatica italiana di consultazione. II. I sintagmi verbale, aggettivale, avverbiale. La subordinazione. Bolonha: Il Mulino, p. 751-817.

MCLAUGHLIN, Barry (1990). Restructuring. Applied Linguistics, 11 (2), p. 113-128.

MEZZADRI, Marco (2003). I ferri del mestiere. Perugia: Guerra Edizioni. 
NorRIS, John M. \& ORTEGA, Lourdes (2000). Effectiveness of L2 Instruction: A Research Synthesis and Quantitative Meta-Analysis. Language Learning, 50 (3), p. 417-528.

NunAn, David (1989). Designing Tasks for the Communicative Classroom. Cambridge: Cambridge University Press.

(1992). Research Methods in Language Learning. Cambridge: Cambridge

University Press.

O’Malley, J. Michael \& Chamot, Anna U. (1990). Learning Strategies in Second Language Acquisition. Cambridge: Cambridge University Press.

ORTEGA, Lourdes (2001). Atención implícita hacia la forma: teoría e investigación. Estudios de lingüistica. Alicante: Universidad de Alicante, p. 179-211.

PAIVA, Vera Lúcia M.O. (2005). "Modelo fractal de aquisição de línguas". In: BRUNO, Fátima T.C. (org.). Ensino-aprendizagem de linguas estrangeiras: reflexão e prática. São Carlos: Claraluz, p. 23-36.

PAllotTI, Gabriele (1998). La seconda lingua. Milão: Bompiani.

(2006). Imparare e insegnare l'italiano come seconda lingua. Roma: Bonacci.

PARROTT, Martin (1993). Task for Language Teachers. A Resource Book for Training and Development. Cambridge: Cambridge University Press.

PecheuX, Michel (1975). Les vérités de la palice. Paris: Maspero.

(1997). Semântica e discurso. Uma crítica à afirmação do óbvio. Tradução de Eni Pulcinelli Orlandi et al. $3^{\text {a }}$ edição. Campinas: Editora da Unicamp.

(2006). O Discurso. Estrutura e acontecimento. Tradução de Eni Puccinelli Orlandi. $4^{\text {a }}$ edição. Campinas: Pontes Editores.

Pienemann, Manfred (1998). Language Processing and Second Language Development. Amsterdã/Filadélfia: John Benjamins Publishing Company.

Platão (1973). A República. Introdução de Robert Baccou; tradução de Jacó Guinsburg. São Paulo: DIFEL.

PORCELLI, Gianfranco (2000). Principi di glottodidattica. Brescia: La Scuola.

Pozzato, Maria Pia (2001). Semiotica del testo. Roma: Carocci.

REEVES, Thomas C. (1991). A Question of Character: a Life of John F. Kennedy, New York: The Free Press. 
REID, Joy (1990). "Responding to Different Topic Types: A Quantitative Analysis from a Contrastive Rhetoric Perspective". In: KROLL, Barbara (org.). Second Language Writing. Research Insights for the Classroom. Cambridge: Cambridge University Press, p. 191-210.

REYES, Graciela (1984). Polifonía textual. La citación en el relato literario. Madri: Gredos.

RENZI, Lorenzo \& SALVI, Giampaolo (orgs.) (1988). Grande grammatica italiana di consultazione. I. La frase. I sintagmi nominale e preposizionale. Bolonha: Il Mulino.

(orgs.) (1991). Grande grammatica italiana di consultazione. II. I sintagmi verbale, aggettivale, avverbiale. La subordinazione. Bolonha: Il Mulino.

\& CARDinaletTI, Anna (orgs.) (1995). Grande grammatica italiana di

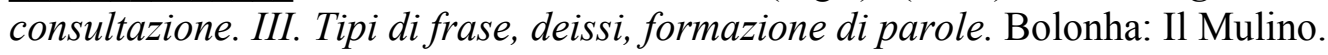

REvuZ, Christine (1998). "A língua estrangeira entre o desejo de um outro lugar e o risco do exílio". In: SignORINI, Inês (org.). Lingua(gem) e Identidade: elementos para uma discussão no campo aplicado. Tradução de Silvana Serrani-Infante. Campinas: Mercado de Letras, p. 213-230.

Ricoeur, Paul (1995). Tempo e narrativa. Tomo II. Tradução de Marina Appenzeller. Campinas: Papirus.

Riffaterre, Michael (1989). A produção do texto. Tradução de Eliane F. P. Lima de Paiva. São Paulo: Martins Fontes.

Robinson, Peter (org.) (2001a). Cognition and Second Language Acquisition. Cambridge: Cambridge University Press.

(2001b). "Task Complexity, Cognitive Resources, and Syllabus Design: A Triadic Framework for Examining Task Influences on SLA". In: ROBINSON, Peter (org.). Cognition and Second Language Acquisition. Cambridge: Cambridge University Press, p. 287318.

(2003). "Attention and Memory during SLA". In: Doughty, Catherine J. \& LONG, Michael H. (2003). The Handbook of Second Language Acquisition. Oxford: Blackwell, p.631-678.

(2005). Cognitive Complexity and Task Sequencing: Studies in a Componential Framework for a Second Language Task Design. International Review of Applied Linguistics, 43 (1), p. 1-32.

Rojo, Roxane \& Batista, Antônio A.G. (orgs.) (2003). Livro didático de língua portuguesa, letramento e cultura da escrita. Campinas: Mercado de Letras.

RomagnOLI, Gabriele (1993). Navi in bottiglia. Milão: Mondadori. 
SALVI, Giampaolo (1988). "La frase semplice". In: RENZI, Lorenzo \& SALVI, Giampaolo (orgs.). Grande grammatica italiana di consultazione. I. La frase. I sintagmi nominale e preposizionale. Bolonha: Il Mulino, p. 29-113.

SAussure, Ferdinand de (1969). Curso de lingüística geral. Tradução de Antônio Chelini et alii. São Paulo: Cultrix.

SCALzo, Rosa Angela (1998). "L'approccio comunicativo. Oltre la competenza comunicativa". In: Serra Borneto, Carlo (org.). C'era una volta il metodo. Tendenze attuali nella didattica delle lingue straniere. Roma: Carocci, p. 137-171.

SchmidT, Richard (1990). The Role of Consciousness in Second Language Learning. Applied Linguistics, 11 (2), p. 129-156.

\& FrotA, Sónia (1986). "Developing Basic Conversational Ability in a Second Language: a Case Study of an Adult Learner of Portuguese". In: DAY, Richard (org.). Talking to learn. Conversation in Second Language Acquisition. Rowley, Mass: Newbury House.

SELINKER, Larry (1969). Language transfer. General Linguistics, 9, p. 67-92.

209-231.

(1972). Interlanguage. International Review of Applied Linguistics, 10, p.

SERIANNI, Luca (1997). Italiano. Grammatica, sintassi, dubbi. Milão: Garzanti.

SERra Borneto, Carlo (org.) (1998). C'era una volta il metodo. Tendenze attuali nella didattica delle lingue straniere. Roma: Carocci.

SERRANI-INFANTE, Silvana (1998). "Identidade e segundas línguas: as identificações no discurso". In: SigNORINI, Inês (org.). Lingua(gem) e Identidade: elementos para uma discussão no campo aplicado. Campinas: Mercado de Letras, p. 231-261.

Serrani, Silvana (2005). Discurso e Cultura na Aula de Lingua. Campinas: Pontes.

(2007). "Legados literário-culturais, memória e antologias na educação em línguas - Currículo de Espanhol no Brasil”. In: Kleiman, Angela \& CAvalcanti, Marilda (orgs.) Lingüística Aplicada. Faces e Interfaces de 25 Anos de Ensino e Pesquisa. Campinas: Mercado de Letras.

SKeHAN, Peter (1994). "Differenze individuali e autonomia di apprendimento". Tradução de Caterina Cianflone. In: MARIANI, Luciano (org.). L'autonomia nell'apprendimento linguistico. Scandicci-Florença: La Nuova Italia, p. 19-38.

(1996). A Framework for the Implementation of Task-based Instruction. $\overline{\text { Applied Linguistics, }} 17$ (1), p. 38-62.

University Press.

(1998). A Cognitive Approach to Language Learning. Oxford: Oxford 
\& Foster, Pauline (2001). "Cognition and Tasks". In: RoBInson, Peter (org.). Cognition and Second Language Acquisition. Cambridge: Cambridge University Press, p. 183-205.

SKYTte, Gunver; SALVI, Giampaolo \& MANZINI, M. Rita (1991). "Frasi subordinate all'infinito". In: RENZI, Lorenzo \& SALVI, Giampaolo. Grande grammatica italiana di consultazione. II. I sintagmi verbale, aggettivale, avverbiale. La subordinazione. Bolonha: Il Mulino, p. 483-569.

STERN, H.H. (1992). Issues and Options in Language Teaching. Oxford: Oxford University Press.

STORCH, Neomy (2001). How Collaborative is Pair Work? ESL Tertiary Students Composing in Pairs? Language Teaching Research, 5 (1), p. 29-53.

SwaIN, Merrill (1985). "Communicative Competence: Some Roles of Comprehensible Input and Comprehensible Output in its Development". In: GASS, Susan \& MADDEN, Carolyn (orgs.). Input in Second Language Acquisition. Rowley: Newbury House, p. 235-253.

(1998). "Focus on Form through Conscious Reflection". In: DouGHTY, Catherine \& Williams, Jessica (orgs.). Focus on Form in Classroom Second Language Acquisition. New York: Cambridge University Press, p. 64-81.

\& LAPKIN, Sharon (1995). Problems in Output and the Cognitive Processes they generate: A Step towards Second Language Learning. Applied Linguistics, 16, p. 371-391.

(2000). Task-based Second Language Learning: The Uses of the First

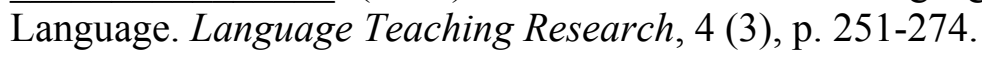

TAMPONI, Anna Rita (2007). "Il task-based approach: come attivare il processo di focalizzazione dell'attenzione e di identificazione dei pattern attraverso task mirati alla produzione scritta". In: CHINI, Marina et alii (orgs.). Imparare una lingua: recenti sviluppi teorici e proposte applicative. Perugia: Guerra Edizioni, p. 353-375.

TAROnE, Elaine E.; Gass, Susan M. \& COHEN Andrew D. (orgs.) (1994). Research Methodology in Second-Language Acquisition. New Jersey: Lawrence Erlbaum Associates.

TAtit, Luiz (1997). Musicando a Semiótica. Ensaios. São Paulo: AnnaBlume. (2001). Análise semiótica através das letras. São Paulo: Ateliê Editorial.

Thomas, Margaret (1994). Assessment of L2 Proficiency in Second Language Acquisition Research. Language Learning, 44, p. 307-336.

UngaretTI, Giuseppe (1994). Razões de uma poesia. Organização de Lucia Wataghin. Tradução de Liliana Laganà, Lucia Wataghin, Maria Betânia Amoroso. São Paulo: Editora da Universidade de São Paulo/Editora Imaginário. 
VAlery, Paul (1999). Variedades. Organização e introdução de João Alexandre Barbosa. Tradução de Maiza M. Siqueira. Posfácio de Aguinaldo Gonçalves. São Paulo: Iluminuras.

VanPatten, Bill \& CADierno, Teresa (1993). Explicit Instruction and Input Processing. Studies in Second Language Acquisition, 15, p. 225-243.

VASSALli, Sebastiano (1971). La poesia oggi. Quaderni di Ant.Ed. Novara: Mora Grafica. (2005). Amore lontano. Il romanzo della parola attraverso i secoli. Turim:

Einaudi.

VedDER, Ineke \& KuIKEN, Folkert (2007). Task Complexity and Linguistic Complexity in L2 Writing. International Review of Applied Linguistics, 45 (3), p. 193-211.

VERnANT, Jean-Pierre (1990). Mito e pensamento entre os gregos: estudos de psicologia histórica. Tradução de Haiganuch Sarian. Rio de Janeiro: Paz e Terra.

Vedovelli, Massimo (2002). Guida all'italiano per stranieri. La prospettiva del Quadro comune europeo per le lingue. Roma: Carocci.

VygOTSKY, Lev Semenovitch (1986). Thought and Language. Cambridge: MIT Press.

(2005). Pensamento e linguagem. Tradução de Jefferson L. Camargo. $3^{\text {a }}$ edição. São Paulo: Martins Fontes.

WidDowson, H. G. (1990). Aspects of Language Teaching. Oxford: Oxford University Press.

WILLIS, Jane (1996). A Framework for Task-based Learning. Londres: Longman.

Oxford: Macmillan.

\& WiLlis, Dave (1996). Challenge and Change in Language Teaching.

Wolfe-Quintero, Kate; InAGAKI, Shunji \& KiM, Hae-Young (1998). Second Language Development in Writing: Measures of Fluency, Accuracy and Complexity. Honolulu: University of Hawai'i Press.

WolfF, Dieter (1994). Der Konstruktivismus: Ein neues Paradigma in der Fremdsprachendidaktik? Die Neueren Sprachen, 93 (5), p. 407-429.

ZENONE, Anna (1982). La consecution sans contradiction donc, par consequent, alors, ainsi, aussi ( $1^{\text {a }}$ parte). Cahiers de Linguistique Française, n. 4, Université de Genève, p. 107-141.

(1983). La consecution sans contradiction donc, par consequent, alors, ainsi, aussi (2 $2^{\mathrm{a}}$ parte). Cahiers de Linguistique Française, n. 5, Université de Genève, p. 7-30. 


\section{ANEXO I-AS ATIVIDADES DIDÁTICAS}

Reproduzimos em seguida as atividades didáticas utilizadas em sala de aula durante nosso curso experimental. Note-se que aos alunos elas eram apresentadas somente em italiano e que a tradução para o português foi realizada apenas para este trabalho. $\mathrm{O}$ aspecto gráfico também foi modificado. Para o trabalho em sala de aula havia um espaço para as respostas reservado aos alunos.

\section{$1^{\circ}$ semestre}

\section{Luca non dimentica}

da Navi in bottiglia di Gabriele Romagnoli

Aveva una memoria d'elefante, Luca. Adesso è un colabrodo, specialmente per i nomi. Eppure ha appena trent'anni. "Chi ha segnato il gol del Milan?» gli chiedono. E lui rovista affannosamente nella formazione. Senza esito. "Come si chiamava quel tuo compagno delle medie grasso grasso?» Niente. Ma non vuole darsi per vinto. È sicuro che la memoria non l'ha davvero abbandonato. Basta spronarla. Deve inventare un sistema che la induca a funzionare. Un premio o un castigo a cui legare i risultati, buoni o cattivi. E alla svelta, per non perderla. Da due ore si tormenta. Cammina nella sera di Milano. Lento, per non far cadere quel nome che sente salirgli alla soglia della mente. Ma che ogni volta incespica. Come si chiamava, Iddio bono: grasso, capelli ricci e neri, occhi distanti, esse sibilante? E ossessionato. Guarda l'orologio. Le sei meno un quarto. "Se non mi viene in mente prima delle sei, allora morirò entro un anno.»

D’accordo. Il patto con il destino è fatto. Adesso ha uno stimolo. Si sente più freddo. Analitico. Ricomincia la rassegna di lettere dell'alfabeto. A, Aba, Ac, Antinori... No niente vocale iniziale. $B, B a, B e, B i$, Bon... Neppure. Le sei meno dieci. Cap, Car, De, niente nomi composti. Gh, Ghi, $M a, M u$. Le sei meno cinque. $P$, Pa, Pe, Po. Le sei meno due. $R$, no $S$, nemmeno $T$, sì, Ta, To, sì, sì, Ton, Tor, Tort... Tortello!!! Si ferma in mezzo alla strada esausto e felice. Guarda l'orologio: le sei spaccate. Un'auto lo travolge.

Da Navi in bottiglia, Gabriele Romagnoli (1993)

E ora tocca a te... [E agora é a sua vez...]

1) Osserva le prime due frasi del testo... Sono basate su due elementi contrapposti. Riesci a identificare quali sono? Quale dei due elementi ti sembra positivo e quale negativo? [Observe as primeiras duas frases do texto... Estão baseadas em dois elementos contrapostos. Você consegue identificar quais são? Qual dos dois elementos lhe parece positivo e qual negativo?] 
2) Che effetto provoca l'uso delle espressioni "memoria d'elefante" e "colabrodo"? Di che tipo di espressioni si tratta? [Que efeito provoca o uso das expressões "memoria d'elefante" e "colabrodo"? De que tipo de expressões se trata?]

3) Che cosa sappiamo del protagonista? [O que sabemos do protagonista?]

4) Ci sono altri "personaggi" nel racconto? [Há outras "personagens" no conto?]

5) In quante sequenze pensi che si possa suddividere questo racconto? [Em quantas seqüências você acredita que esse conto possa ser dividido?]

6) Cerca nel testo tutte le espressioni riferite al tempo e riportale qui di seguito. Sapresti dire che effetto provocano? [Procure no texto todas as expressões que se referem ao tempo e transcreva-as aqui. Você saberia dizer qual o efeito que elas provocam?]

7) Quante volte compare nel testo il discorso diretto? Prova a riprodurre le frasi e a scoprire: chi parla? Qual è l'effetto che si vuole ottenere utilizzando questa strategia? [Quantas vezes aparece no texto o discurso direto? Experimente reproduzir as frases e descobrir: quem fala? Qual o efeito que se quer obter utilizando essa estratégia?]

8) Nel testo ci sono due riferimenti ad una città italiana. Di quale città si tratta? Sai in quale regione si trova e che cosa rappresenta in Italia? Se non lo sai, cerca informazioni... [No texto há duas referências a uma cidade italiana. De que cidade se trata? Você sabe em que região fica e o que ela representa na Itália? Se você não souber, procure informações...]

9) E per concludere una "sfida": riesci a dire che cosa significa "Luca non dimentica"? [E para terminar um "desafio": você sabe dizer o que significa "Luca não esquece"?] 


\title{
$2^{\circ}$ semestre
}

\author{
Ha partorito, \\ sono partito, \\ sono andato all'ospedale: \\ «Come va?» \\ «Non c'è male» \\ L'ho sposata. \\ «Come è andata?» \\ «亡̀ andata \\ via». Allora \\ l'ho sposata ancora. \\ «Come va?» \\ «Va». Ma \\ ho lasciato anche lei, \\ parto alle sei.
}

(Giorgio Manacorda, Soldato segreto, 1999)

Dopo aver letto la poesia, proviamo ad osservarla più da vicino... [Após ler o poema, tentemos observá-lo mais de perto...]

1) Prova a confrontare le tue prime impressioni con un collega... Cercate insieme di scrivere quello che vi siete detti. [Experimente comparar suas primeiras impressões com um colega... Tentem juntos escrever aquilo que vocês se disseram.]

2) Di che cosa pensate che "parli" questa poesia? $O$, in altre parole, quale vi sembra il tema principale? A partire da quali elementi lo riconoscete? [Do que "fala", segundo vocês, esse poema? Ou, em outras palavras, qual parece ser o tema principal? A partir de quais elementos vocês o reconhecem?]

3) Provate ad individuare gli attori: chi parla? Con chi? Di chi? [Experimentem individuar os atores. Quem fala? Com quem? De quem?] 
4) Secondo voi, che effetto vuole creare l'enunciatore quando decide di introdurre il discorso diretto? [Na opinião de vocês que efeito quer criar o enunciador quando decide introduzir o discurso direto?]

5) La poesia gioca sul doppio significato del verbo "andare". Provate ad esaminare tutte le occorrenze del verbo e a decidere qual è il significato giusto per ognuna e a chi o a che cosa si riferiscono... [O poema joga com o duplo sentido do verbo andare. Examinem todas as ocorrências do verbo para decidir qual é o significado para cada uma delas e a quem ou ao quê elas se referem...]

6) Un altro doppio gioco è quello dei due piani temporali del presente e del passato. Provate a separare i due tempi verbali e a pensare a dove compaiono e perché. [Mais um jogo duplo é o dos dois planos temporais, do presente e do passado. Experimentem separar os tempos verbais de cada um deles para pensar onde aparecem e por quê.]

7) Provate ora a guardare la poesia ancora più da vicino: vengono usati stratagemmi particolari sul piano dell'espressione (rima, assonanza, allitterazione,...)? Che effetto creano? [Olhem agora o poema ainda mais de perto: são usados recursos específicos no plano da expressão (rima, assonância, aliteração, ...)? Que efeito criam?

8) Come descrivereste l'immagine dell'enunciatore fornita da questo testo, ovvero: come vi immaginate colui che parla? Quale vi sembra il tono della poesia? [Como vocês descreveriam a imagem do enunciador dada por esse texto, isto é: como vocês imaginam quem fala? Qual parece ser o tom do poema?]

9) E per finire... Pensate di essere adesso in grado di ricostruire "quello che succede" in questa poesia? [E para concluir... Vocês acham que conseguem reconstruir "aquilo que acontece" nesse poema?] 


\section{$3^{\circ}$ semestre}

Il titolo del racconto, tratto da Navi in bottiglia, è: [O título do conto, extraído de Navi in bottiglia, é:]

\section{OCCHI DI PAOLA}

1) A che cosa ti fa pensare questo titolo? Quale credi che potrebbe essere il tema del racconto a partire da questo titolo? Fai delle ipotesi e confrontati con un compagno. [Em que lhe faz pensar esse título? Qual você acredita que possa ser o tema do conto a partir dele? Faça hipóteses e compare com um colega.]

\section{2) Adesso leggiamo: [Agora vamos ler:]}

Non può dormire. Qualcosa lo tormenta. Ma non riesce a capire cosa. Fatto sta che da due ore si rigira nel letto, lui che, come dice Paola, dorme a comando. La guarda, addormentata sul fianco. Dalla massa dei capelli scuri, ora tinti, emerge nella semioscurità il profilo della guancia, ancora piena e morbida. I suoi grandi occhi sono nascosti dalle palpebre, ma Duccio li immagina, azzurri, appena ingrigiti dagli anni. E d'improvviso capisce. É per quel pomeriggio. Esattamente vent'anni prima. Il pomeriggio in cui tradi Paola. Con la moglie di un suo caro amico, per giunta. Poi tornò a casa, si fece la doccia, mangiò con lei, scherzò, guardarono la tv. Quando andarono a letto, lui si addormentò subito. Dunque è così che vanno le cose, pensò, al risveglio: nessun rimorso, nulla cambia. Si può tradire e farla franca, anche con se stessi. Si può tranquillamente convivere con i propri peccati.

Non l'ha più fatto. Aveva perfino dimenticato che fosse accaduto. Ora ricorda. Guarda Paola e vorrebbe urlare. Lei si sveglia, lo vede seduto sul letto. "Cosa ti succede, come mai sei sveglio?» domanda. "Ho avuto un incubo" risponde lui. "Ho sognato che ti tradivo con Franca, sai, la moglie di Giorgio.» Lei si gira dalla sua parte. Gli accarezza la mano. "Grazie per averlo chiamato incubo» dice. Lui sorride, si sdraia nuovamente. Lei continua ad accarezzargli la mano e subito lui si addormenta. Si spengono i lampioni della piazzetta. Ora la stanza è buia. Nell'oscurità gli occhi di Paola sono aperti. Un po' meno azzurri, un po ' più grigi.

Da Navi in bottiglia, Gabriele Romagnoli (1993)

3) Dopo la lettura del testo, prova a rispondere confrontando con le ipotesi che hai fatto. Qual è il tema del racconto? [Após a leitura do conto, tente responder comparando com as hipóteses que você fez. Qual é o tema do conto?] 
4) Riesci ad identificare una o più coppie di elementi contrapposti sulle quali potrebbe basarsi il senso di ciò che viene narrato? Cerca di riconoscerle e scrivi in una colonna gli elementi positivi $\mathbf{e}$ in un'altra quelli negativi. [Você consegue identificar uma ou mais duplas de elementos contrapostos nos quais poderia basear-se o sentido daquilo que é narrado? Tente reconhecê-las e escreva numa coluna os elementos positivos e em outra os negativos.]

Elementi positivi

[Elementos positivos]

\section{Elementi negativi}

[Elementos negativos]

5) Quali sono gli attori (le "voci" esplicite o implicite) che partecipano alla costruzione del testo? [Quais são os atores (as "vozes" explícitas ou implícitas) que participam da construção do texto?]

6) C'è nel testo un soggetto che si dichiara "responsabile" di quello che viene detto? Chi narra? $\mathbf{E}$ in che posizione si pone rispetto al lettore? [Há no texto um sujeito que se declara responsável por aquilo que é dito? Quem narra? E em que posição se coloca em relação ao leitor?]

7) Nel testo viene usato il tempo - Quali sono gli effetti di senso che provoca l'uso di questo tempo? [No texto é usado o tempo . Quais são os efeitos de sentido que provoca o uso desse tempo?]

8) Quali strategie usa l'enunciatore del testo per costruire l'effetto di senso della verità e dell'oggettività? Trovane almeno tre: [Quais recursos utiliza o enunciador do texto para construir o efeito de sentido da verdade e da objetividade? Ache, ao menos, três:]

a)

b)

c)

d)

e) 
9) Pensiamo alla testualizzazione (cancella l'alternativa che ritieni sbagliata): [Pensemos agora na textualização (apague a alternativa que você considera errada):]

Il testo è costituito soprattutto da proposizioni

principali/subordinate ; si osserva la presenza

di coordinate sindetiche/asindetiche e quindi ci sono

molti/pochi connettivi. Le frasi sono, quindi, brevi/lunghe questo crea un effetto connettivi. Le frasi sono, quindi, brevi/lunghe e questo crea un effetto rilassato/di suspense e mostra che l'éthos dell'enunciatore si può definire concitato/calmo e $\quad$ accelerato/rallentato. Il discorso è concentrato/disperso.

[O texto é costituído principalmente por orações principais/subordinadas ; observa-se a presença de coordenadas sindéticas/assindéticas e, portanto, há muitos/poucos conectivos. As frases são, então, curtas/longas e isso cria un efeito relaxado/de suspense além de mostrar que o éthos do enunciador pode-se definir tenso/calmo e acelerado/lento. discurso é concentrado/disperso. ]

10) Rileggi ora con attenzione l'inizio del racconto. Come e in quale momento viene introdotto il protagonista maschile della storia? Che effetto crea questo stratagemma? [Leia agora de novo com atenção o início do conto. Como e em que momento é introduzido o protagonista masculino da história? Que efeito cria esse recurso?]

11) Osserva l'immagine usata all'inizio del racconto (Non può dormire. Qualcosa lo tormenta.) La stessa immagine viene usata in altri due momenti cruciali del racconto. Cercali e prova a concludere che cosa può rappresentare. [Observe a imagem utilizada no início 
do conto (Não pode dormir. Alguma coisa o atormenta.) A mesma imagem é usada em outros dois momentos cruciais do conto. Procure-os e tente dizer o que podem representar.]

12) Il narratore riporta una descrizione fisica di Paola così come la vede Duccio. Di che tipo di descrizione si tratta? La definiresti positiva (euforica) o negativa (disforica)? Perché? [O narrador faz uma descrição física de Paola, assim como a vê Duccio. De que tipo de descrição se trata? Você a definiria como positiva (eufórica) ou negativa (disfórica)? Por quê?]

13) Verso la metà del primo paragrafo tre brevi frasi indicano un importante cambiamento nella narrazione. Di quali frasi si tratta? Che cosa provocano nel racconto? [Aproximadamente na metade do primeiro parágrafo três breves frases indicam uma importante mudança na narração. De que frases se trata? O que provocam no conto?]

a)

b)

c)

14) Una delle frasi contiene il verbo capire. A quale altra parte del testo credi che si possa riferire? [Uma das frase contém o verbo capire (entender). A qual outra parte do texto você acredita que se possa referir?]

15) Alla fine del primo paragrafo l'enunciatore riporta un pensiero di Duccio. Analizzalo insieme a un compagno riflettendo e cercando di trarre conclusioni a partire dai seguenti punti: [No fim do primeiro parágrafo o enunciador transcreve um pensamento de Duccio. Analise-o junto com um colega, refletindo e procurando chegar a alguma conclusão a partir dos seguintes pontos:]

- uso delle virgolette; [uso das aspas]

- forma (persona) e tempo verbale usati; [forma (pessoa) e tempo verbal usados]

- rapporto di questa frase con il resto del racconto. [relação dessa frase com o resto do conto]

16) Con quale tempo verbale inizia il secondo paragrafo? Che effetto credi che l'uso di questo tempo possa avere sul testo? [Com qual tempo verbal começa o segundo parágrafo? Que efeito você acredita que o uso desse tempo possa ter no texto?]

17) Questo stesso tempo verbale viene usato altre due volte. Dove? Che cosa possiamo concludere a partire da questo dato di fatto? [O mesmo tempo verbal é usado mais duas vezes. Onde? O que podemos concluir a partir desse fato?] 
18) Il titolo e poi anche il resto del racconto contengono diversi riferimenti al campo visivo. Cercali e riportali qui sotto. [O título e depois também o resto do conto contêm diversas referências ao campo visual. Procure-as e transcreva-as aqui.]

19) Il colore degli occhi di Paola contiene la chiave di lettura del racconto. Ripensa ai due colori menzionati e alle associazioni possibili. [A cor dos olhos de Paola contém a chave de leitura do conto. Repense nas duas cores mencionadas e nas possíveis associações.]

COLORE [cor]:

COLORE [cor]:

20) Quale credi che sia l'opinione del "testo" (enunciatore, narratore, personaggi) riguardo al peccato e all'impunità? Da che cosa lo deduci? [Qual você acredita ser a opinião do "texto" (enunciador, narrador, personagens) em relação ao pecado e à impunidade? A partir de quais elementos você o deduz?]

21) E qual è la tua opinione riguardo al tema trattato? Discutine con un compagno... [E qual é a sua opinião sobre o tema tratado? Converse sobre isso com um colega...] 


\section{$4^{\circ}$ semestre}

Se ora tu bussassi alla mia porta

e ti togliessi gli occhiali

e io togliessi i miei che sono uguali

e poi tu entrassi dentro la mia bocca

senza temere baci disuguali

e mi dicessi: «Amore mio,

ma che è successo?», sarebbe un pezzo

di teatro di successo.

(Patrizia Cavalli, Poesie (1974-1992), 1992)

- Dopo aver letto attentamente e ad alta voce la poesia, prova a scrivere le prime tre cose che ti ha fatto venire in mente: [Após ler com atenção e em voz alta o poema, experimente escrever as três primeiras coisas que lhe vieram à mente:]

1)

2)

3)

- Di che cosa "parla" la poesia? Con quali parole ne definiresti il tema? [Do que "fala" o poema? Com que palavras você definiria o tema?]

- Osserva adesso attentamente il primo verso... Analizzane gli elementi cercando di pensare a tutti quelli che sono, secondo te, i riferimenti possibili... (tempo, spazio, persona, ...) [Observe agora com atenção o primeiro verso... Analise os elementos presentes procurando pensar em todas as que são, na sua opinião, as referências possíveis... (tempo, espaço, pessoa, ...)]

- La poesia inizia con un "se"... Ritorna al testo e analizza in che maniera si può dividere in due parti a partire da questa congiunzione... [O poema começa com um "se"... Volte a ele e analise de que maneira pode ser dividido em duas partes a partir dessa conjunção...] 


\begin{tabular}{|c|l|}
\hline $\begin{array}{c}\text { 1a } \\
\text { parte }\end{array}$ & \\
\hline $\begin{array}{c}\text { a } \\
\text { parte }\end{array}$ & \\
\hline
\end{tabular}

- Il testo è, quindi, un - La prima parte si chiama

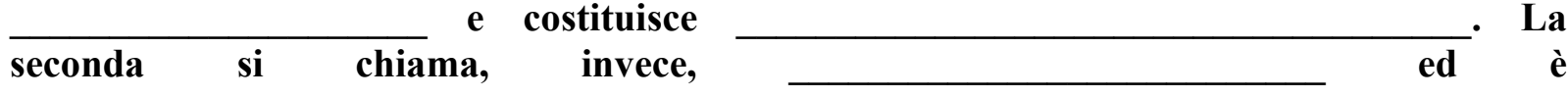
- O texto é, então, um e constitui A primeira parte chama-se se, ao contrário, . A segunda chama-

$\longrightarrow$

- La poesia contiene due avverbi di tempo. Quali? In che rapporto sono con il tipo di struttura su cui è costruito il testo e come lo influenzano o ne sono influenzati? [O poema contém dois advérbios de tempo. Quais são? Em que relação estão com o tipo de estrutura com base na qual é construído o texto e como o influenciam ou são influenciados por ela?]

- E il discorso diretto? Che funzione ha in un testo come questo? [E o discurso direto? Que função tem num texto como esse?]

- Prova a dare una tua interpretazione delle "parole fra virgolette"... [Experimente dar sua interpretação sobre as "palavras entre aspas"...]

- Come si ricollegano alla parte finale del testo? [De que forma estão ligadas à parte final do texto?]

- Come giustificheresti la ripetizione della parola "successo"? Quali significati credi che abbia? [Como você justificaria a repetição da palavra "successo"? Quais significados você acredita que pode ter?]

- Cerca ora di individuare in tutto il testo gli elementi attraverso i quali si parla di: [Tente agora identificar em todo o texto os elementos por meio dos quais se fala de:] 


\begin{tabular}{|l|l|}
\hline $\begin{array}{l}\text { PERSONA [PESSOA] } \\
\text { soggetto/i dell'enunciato } \\
\text { [sujeito(s) do enunciado] }\end{array}$ & SPAZIO [ESPAÇO] \\
\hline & \\
\hline & \\
\hline
\end{tabular}

- A quali conclusioni su persona e spazio possiamo arrivare analizzando questi elementi? In altre parole: [A quais conclusões sobre pessoa e espaço podemos chegar analisando esses elementos? Em outras palavras:]

${ }^{\circ}$ Chi parla con chi? In che modo? [Quem fala com quem? De que maneira?]

${ }^{\circ}$ Dove? Con quali riferimenti allo spazio? [Onde? Com que referências ao espaço?]

- Quali figure ti hanno maggiormente colpito? Prova ad individuarle e a riportarle qui di seguito. [Quais figuras chamaram mais a sua atenção? Tente individuá-las e transcreva-as aqui.]

- In vari punti il testo della poesia cita o rimanda a parti del corpo umano. Prova ad individuarli e a ipotizzarne il significato... [Em vários momentos o texto do poema cita ou faz referência implícita a partes do corpo humano. Tente individuá-los e faça hipóteses quanto ao seu provável sentido...]

- Prova ora a guardare la poesia ancora più da vicino: vengono usati stratagemmi particolari sul piano dell'espressione (rima, assonanza, allitterazione, ...)? Se sì, che effetto creano? [Tente agora olhar o poema ainda mais de perto: são utilizados recursos no plano da expressão (rima, assonância, aliteração, ...)? Em caso afirmativo, que efeito criam?]

- E per finire: come definiresti l'éthos, il modo di presenza, il tono dell'enunciatore (soggetto dell'enunciazione) di questa poesia? [E para concluir: como você definiria o éthos, o modo de presença, o tom do enunciador (sujeito da enunciação) desse poema?] 


\section{$5^{\circ}$ semestre}

\section{L'onorevole doppia chance}

Buffo. Buffo essere nella stanza di un albergo di Palermo e vedersi in tv, mentre risponde alle domande dei giornalisti e degli spettatori. Un privilegio, in fondo. Come se il tempo e lo spazio offrissero sempre a quelli come lui una scappatoia. La possibilità, addirittura, di vivere una doppia vita. "Onorevole, come vicepresidente della commissione antimafia, cosa ritiene di aver realizzato, oltre a un rapporto di mille pagine che fotografa Cosa Nostra ma non la scalfisce?» Sorseggia un'aranciata amara e sorride ascoltandosi rispondere: sicuro di sé, sguardo deciso, ciuffo kennediano sulla fronte. "Innalzamento della guardia." "Denuncia senza rumore." "Faremo i nomi dei collusi." Funziona. Rielezione assicurata. Specialmente se $i$ voti glieli ha garantiti la famiglia. "Trentamila preferenze se ti presenti a Palermo con la patente di nemico numero uno delle cosche e ci cacci fuori dalle palle D'Ottavio.» Affare fatto. E adesso, qualche presenza di rito. Cena al Rotary, stasera. Si alza. Stringe il nodo della cravatta nera. In tv ne ha una rossa. Stacca di più. Doppia vita, anche tripla magari. Forse in questo momento una radio privata trasmette una sua intervista. E certo il capofamiglia non sa che lui e D'Ottavio hanno un accordo.

«Onorevole, non teme per la sua vita?» sta chiedendo un giornalista. Esce dalla stanza lasciando la tv accesa per mantenere l'ubiquità. Un sicario gli spara nei corridoi dell'albergo e fugge.

La voce dallo schermo non si incrina: "Temo di più per le sorti dei valori che rappresento».

Da Navi in bottiglia, Gabriele Romagnoli (1993)

1) Dopo aver letto attentamente il racconto, scrivi le prime cose che ti ha fatto venire in mente e confrontati poi con un compagno... [Após ler com atenção o conto, escreva as primeiras três coisas em que ele o fez pensar e compare depois com um colega:]

2) Adesso che hai letto il racconto e hai confrontato le tue prime impressioni con quelle di un compagno, prova ad identificare il tema (o i temi) del racconto. Cerca iterazioni semiche che possano aiutarti. [Agora que você leu o conto e que comparou suas primeiras impressões com as de um colega, tente identificar o tema (ou os temas) do conto. Procure iterações sêmicas que o possam ajudar...] 


\begin{tabular}{|l|l|}
\hline TEMI (temas) & $\begin{array}{l}\text { ITERAZIONI SEMICHE (iterações } \\
\text { sêmicas) }\end{array}$ \\
\hline & \\
\hline & \\
\hline & \\
\hline & \\
\hline
\end{tabular}

3) Osserva ora i lessemi che hai trovato per ognuno dei temi. Credi che siano essenzialmente termini concreti (figure) o astratti (concetti)? Quali potrebbero essere, secondo te, le conseguenze di questo modo di scrivere? [Observe agora os lexemas que você encontrou para cada um dos temas. Você acha que se trata essencialmente de termos concretos (figuras) ou abstratos (conceitos)? Quais poderiam ser, na sua opinião, as conseqüências dessa maneira de escrever?]

4) Proviamo ora a guardare com'è costruito il testo dal punto di vista della PERSONA... Scrivi tutto quello che riesci ad osservare ed in particolare come vengono introdotti, come si manifestano, come "parlano" e che caratteristiche hanno: (a) l'attore principale (o soggetto dell'enunciato); (b) i personaggi secondari; (c) il narratore; (d) l'enunciatore. [Vamos agora olhar como é construído o texto do ponto de vista da PESSOA.... Escreva tudo o que você consegue observar e especialmente como são introduzidos, como se manifestam, como "falam" e que características têm: (a) o ator principal (o sujeito do enunciado); (b) as personagens secundárias; (c) o narrador; (d) o enunciador.]

5) Guardiamo ora il TEMPO. Individua e prova a spiegare la funzione e l'effetto dei seguenti elementi: (a) tempo principale della narrazione; (b) altri tempi verbali eventualmente presenti; (c) avverbi e le locuzioni di tempo. [Vamos olhar agora o tempo. Identifique e tente explicar a função e o efeito dos seguintes elementos: (a) tempo principal da narração; (b) outros tempos verbais eventualmente presentes; (c) advérbios e expressões de tempo.]

6) Vediamo come viene organizzato lo SPAZIO. Le azioni descritte si svolgono in almeno due luoghi. Quali sono? [Vejamos como é organizado o ESPAÇO. As ações descritas acontecem em, ao menos, dois lugares. Quais são?]
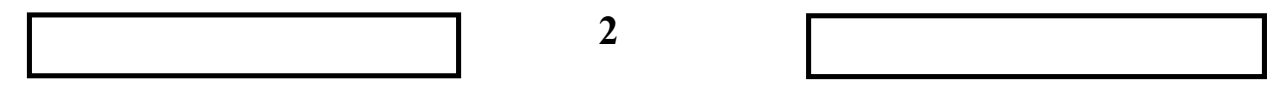
Quali azioni vengono svolte in ciascuno dei due luoghi? [Quais ações acontecem em cada um dos dois lugares?]

\begin{tabular}{|l|l|}
\hline LUOGO 1 & LUOGO 2 \\
& \\
& \\
\hline
\end{tabular}

Credi che ci siano altre osservazioni da fare sullo spazio? [Você acredita que devam ser feitas outras observações sobre o espaço?]

Prova a fare delle ipotesi sulla questione del doppio gioco? Secondo te, perché viene introdotta? [Faça hipóteses sobre a questão do jogo duplo. Na sua opinião, por que é introduzida?] 


\section{$6^{\circ}$ semestre}

\section{La poesia oggi}

$\mathrm{Ci}$ sono persone ovunque, anche in questo paese,

Che siedono attorno a "tavole rotonde",

Che prendono e danno premi, che scrivono

"La poesia oggi" oppure "la funzione del poeta".

Della funzione del poeta non saprei dire nulla;

La poesia oggi - questa sì, io la posso indicare,

Sta nei grandi magazzini, nei settimanali illustrati,

Nella pubblicità al cinema, nelle facce della gente

Che vede le famose cortigiane, gli animali lussuosi e splendidi, Che instillarono nel cuore del "poeta" l'Ideale lontano, per cui in milioni morirono o delirando vissero, Passare dalla saponetta al vinello toscano

All'abito già pronto, imprimersi in suggello D'un amore lontano su birra o su profumo Risciacquar pavimenti o sturare un lavabo - La gente guarda e tace, entra al supermercato.

1) Dopo aver letto attentamente e ad alta voce la poesia, prova a scrivere le prime tre cose che ti ha fatto venire in mente: [Após ler com atenção e em voz alta o poema, experimente escrever as três primeiras coisas em que ele o fez pensar:]

a)

b)

c)

2) Di che cosa si parla in questa poesia? Con quali parole ne definiresti il tema generale? [Do que se "fala" nesse poema? Com que palavras você definiria o tema geral?] 
3) Prova adesso a rileggere attentamente le quattro strofe che compongono la poesia... In quante parti credi che si possa dividere? [Tente agora ler novamente com atenção as quatro estrofes que compõem o poema... Em quantas partes você acha que se pode dividi-lo?]

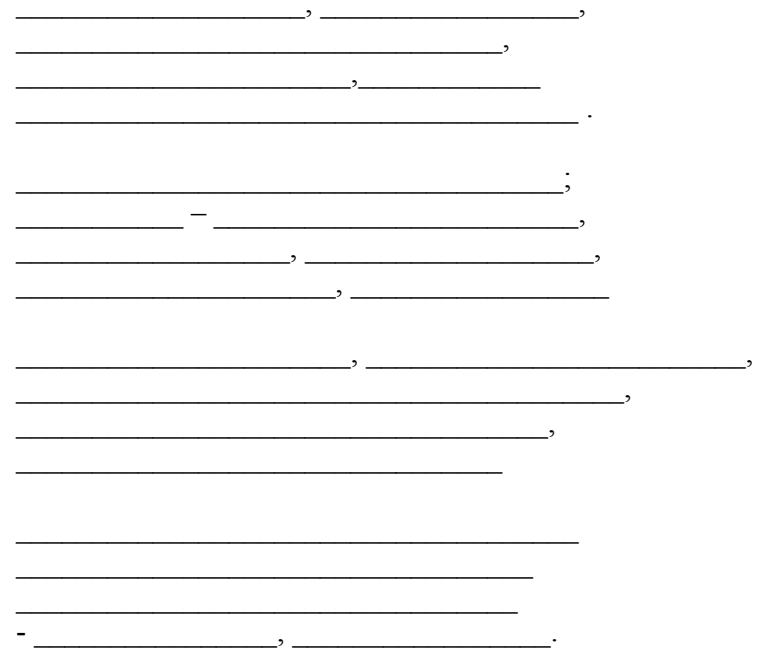

Perché? [Por quê?]

4) La suddivisione della poesia riporta ad universi diversi. Come li definiresti? Secondo te, quali sono gli elementi attraverso i quali vengono inseriti nel testo? [A segmentação do poema remete a universos diferentes. Como você os definiria?]

5) Prova ora a cercare nel testo ciò che si riferisce al TEMPO (avverbi, aggettivi, tempi verbali, ...) e riportali qui di seguito. [Procure agora no texto aquilo que se refere ao TEMPO (advérbios, adjetivos, tempos verbais, ...) e transcreva tudo aqui.]

\begin{tabular}{|l|l|}
\hline TITOLO [Título] & \\
\hline 1a strofa & \\
\hline 2a strofa & \\
\hline 3a strofa & \\
\hline 4a strofa & \\
\hline
\end{tabular}


6) Come credi che possano essere interpretati e che valore possono avere all'interno del testo? [Como você acha que podem ser interpretados e que valor podem ter no interior do texto?]

7) Ripercorri ora il testo pensando allo SPAZIO. Quali elementi testuali lo indicano? [Leia de novo o texto pensando no ESPAÇO. Quais elementos textuais o indicam?]

8) Passiamo adesso alla PERSONA: chi parla? E di chi? [Passemos agora à PESSOA. Quem fala? E de quem?]

9) Diresti che l'ultimo verso può essere interpretato come discorso diretto? Che funzione pensi che abbia in un testo come questo? [Você diria que o último verso pode ser interpretado como discurso direto. Que função você acha que isso tem num texto como esse?]

10) Prova a dare una tua interpretazione dell'ultimo verso: a quale aspetto della società contemporanea credi che faccia riferimento? [Dê sua interpretação do último verso? A que aspecto da sociedade contemporânea você acha que se refere?]

11) Osserva nel testo le parole poeta e poesia. Secondo te, che effetto crea la ripetizione? $E$ l'uso delle virgolette? [Observe no texto as palavras poeta e poesia. Segundo você, que efeito cria a repetição? E o uso das aspas?]

12) E le virgolette usate per l'espressione "tavole rotonde"? Cosa significano, secondo te? [E as aspas usadas para a expressão "mesas redondas"? O que significam, na sua opinião?]

13) Quali figure considereresti centrali per l'interpretazione della poesia? Prova ad individuarle e a riportarle qui di seguito. [Quais figuras você consideraria centrais para a interpretação do poema? Tente identificá-las e transcreva-as aqui.]

15) Prova ora a guardare la poesia ancora più da vicino: vengono usati stratagemmi particolari sul piano dell'espressione (rima, assonanza, allitterazione, ...)? Se sì, che effetto creano? [Tente agora olhar o poema mais de perto. São utilizados recursos no plano da expressão (rima, assonância, aliteração, ...)? Em caso afirmativo, que efeito criam?] 
16) E per finire: come definiresti l'éthos, il modo di presenza, il tono dell'enunciatore (soggetto dell'enunciazione) di questa poesia? [E para terminar: como você definiria o éthos, o modo de presença, o tom do enunciador desse poema?] 


\title{
ANEXO II-AS REDAÇÕES DOS ALUNOS
}

\author{
Reproduzimos aqui na íntegra e sem alterações as redações dos dez alunos \\ selecionados para pesquisa. Os alunos são identificados, como no texto, com letras de A a \\ $\mathrm{J}$ e as seis redações com números de 1 a 6 , indicando o semestre em que foram \\ produzidas.
}

\begin{abstract}
ALUno A
(A1)

Questo racconto parla del protagonista Luca, che aveva una memoria d'elefante e adesso ai trent'anni è un colabrodo. Quando gli chiedono chi ha segnato il gol del Milan, non ricorda niente.

Luca fa un patto con il destino: si non ricordare il nome prima delle sei, morirà in un anno. Come ricorda il nome alle sei spaccate, un'auto lo travolge. Gli altri protagonisti sono l'auto e la memoria.

All'inizio del racconto Luca è ossessionato, rovista affannosamente nella formazione. Dopo che fa il patto si sente più freddo perché passa la responsabilità della memoria per il destino.

Quando leggiamo il racconto, il discorso direto all'inizio del testo crea un effetto di vicinanza, crea le ilusione che siamo di fronte della persona che parla.
\end{abstract}

\section{(A2)}

La prima impressione sulla poesia è di che sia una conversazione, paralella, un miscuglio di dialoghe, perché ad inizio del testo sembra un po' confuso. Dopo analisare più da vicino, si può osservare che si trata di un io, provabilmente il marito, che parla con un tu (un amico) sul suoi matrimoni.Questo può essere comprovato per la desinenza del verbo "sono partito" e per l'inserzione dei dialoghe.

È possibile dire che il tema principale sia la nascita e la morte. Questo tema viene tratado di modo cotidiano, la lingua è abastanza semplice. La nascita si riferisce al parto della prima moglie dell'io e la morte si riferisce alla fine del primo matrimonio.

Il racconto dell'io è fatto atraverso l'uso del discorso indireto associato al tempo passato nella maggior parte della poesia e il discorso direto viene associato al tempo presente rappresentando respettivamente la conversazione fra la moglie e il marito: "Come va?" v.4 "Non c'è male" v.5; e la conversazione fra il marito e l'amico: "Come è andata?" v.7 "È andata/via" v.8-9; creando un effetto di realtà e vicinanza, poi il lettore ha l'iluzione di ascoltare il dialogo fra loro.

Altri aspetto interessanti sono: il ritmo ed il doppio significato del verbo andare. Il ritmo creato per la rima, l'assonanza e l'alliterazione retoma il senzo cotidiano della poesia. Il doppio significato del verbo andare ocorre nel verso "È andata via". Il primo significato è associato alla paroala "via" che dà un senso di che il matrimonio è finito. Il secondo significato è di che la moglie ha partito.

L'enunciatore ha una immagine fredda e supperiore in relazione alla moglie. Al momento che dice "ho sposato a lei" la moglie si incontra di modo inferiore. Il tono della poesia è ironico per l'uso del gioco di parole e l'ultimo verso "parto alle sei" che dà l'impressione che la fine del matrimonio non è importante.

Con base in questi elementi si concluisce che la storia della poesia è di un uomo che si è sposato due volte e racconta ad un amico sulla fine dei due matrimoni. Alla fine della poesia, con il termino dell'ultimo matrimonio si ancora la vita dell'io. 
(A3)

Si può dire che "Occhi di Paola", racconto tratto da "Navi in bottiglia", ha come tema principale il tradimento. Duccio, protagonista della storia, ha tradito sua moglie, Paola, con Franca, la moglie del suo amico Giorgio.

La narrazione è fatta in terza persona, il protagonista ci è presentato cataforicamente. All'inizio sappiamo pure che è un uomo dall'uso del pronome "lo" in "Qualcosa lo tormenta" alla prima riga. Questo stratagemma insieme ad altri elementi creano un'impressione di attesa, trattene il lettore. Le strutture del testo riportano anche alle caratteristiche psicologiche del protagonista. All'inizio Duccio è tormentato, non può dormire. Quest'immagine viene rinforzata dai periodi semplici e dalle frasi brevi nella maggior parte del testo e dall'uso di pochi connettivi. Il tempo verbale usato nella narrazione è il presente, però vengono usati anche il passato remoto e il passato prossimo creando un gioco tra il tempo di riferimento e il tempo della narrazione. Così quando il narratore usa il passato remoto riguardando al tradimento, il suo obiettivo è di allontanare quello che è successo in relazione al momento dell'enunciazione.("Il pomeriggio in cui tradì Paola")

Alla fine del primo paragrafo il narratore riporta attraverso il discorso indiretto libero, un pensiero di Duccio in cui la scelta della terza persona singolare (forma impersonale) ed il tempo verbale (presente) può indicare che anche il narratore é d'accordo com l'opinione del protagonista. ("... nessun rimorso, nulla cambia...") Un altro stratagemma interessante è l'uso del discorso diretto che insieme all'uso dei crononimi, dell'antroponimi, della descrizione psicologica dei personaggi e della linearità di avvenimenti, creano un effetto di realtà. Il lettore ha l'impressione di essere testimone della storia.

Si può osservare anche l'opposizione tra i colori (azzurro e grigio) che compare all'inizio e alla fine del racconto riguardando gli occhi di Paola. Gli occhi compaiono nel testo come elemento centrale che collegato con le altre parole chiave come rimorso e peccato, creano un gioco tra l'oscurità e il chiarore. Questo gioco è presente in tutto il racconto. All'oscurità si può collegare la colpa, il rimorso, il colore grigio degli occhi, l'incertezza, la possibilità della punizione, il pentimento, l'incubo, tra altre cose e al chiarore si può collegare il sogno, la concienza tranquilla, l'innocenza, ecc. All'inizio i colori (azzurro e grigio) creano un'opposizione tra vecchiaia e gioventù e alla fine questi colori rappresentano l'opposizione tra la certezza e il dubbio. Perchè si può dire che c'è un'inversione tra i personaggi Paola e Duccio. All'inizio Paola era addormentata e tranquilla mentre Duccio era agitato, non poteva dormire. Adesso Duccio dorme mentre Paola dopo aver saputo del contenuto dell'incubo del marito, ha gli occhi aperti. Il lettore ha l'impressione che il dubbio che tormentava Duccio, tormenta adesso lei. Il buio della stanza puó rappresentare anche l'opposizione alla semioscurità dell'inizio e l'incertezza del lettore riguardo al significato dei colori, cioè, non siamo sicuri se lei ha scoperto il tradimento. ("Ora la stanza è buia. Nell'oscurità gil occhi di Paola sono aperti. Un po' meno azzurri, un po'piu grigi").

\section{(A4)}

La poesia di Patrizia Cavalli viene introdotta da una situazione enunciazionale creata sulla base del piano ipotetico, in cui la prima lettura permette di definire il tema come quello di un rapporto amoroso. Così i riferimenti immediati alla persona che compaiono nella poesia (io /tu) danno al lettore la possibilità di tre chiavi di interpretazione. La prima ipotesi può essere costruita considerando "l'io"come un uomo e il "tu" come una donna. Se fosse così, la poesia rappresenterebbe una situazione in cui un uomo pensa cosa sarebbe successo se la sua fidanzata fosse entrata a casa sua e si comportasse in maniera più sensuale e diversa dal solito. In questo caso, "i baci disuguali" sarebbero baci che esprimono più sensualità e l'uso del discorso diretto $(<<$ Amore mio, ma che è successo? $>>)$ rappresenterebbe la sorpresa dell'io davanti a questo comportamento del "tu". Una seconda possibilità sarebbe identificare "l'io" e il "tu" come una coppia omossesuale così "i baci disuguali" rappresenterebbero baci che non sono accettabili per la società e questa situazione avrebbe una singolarità proporzionale a quella di un pezzo di teatro di successo. La terza possibilità sarebbe identificare "l'io" come una donna e il "tu" come un uomo. Lasciamo da parte le due prime possibilità e prendiamo quest'ultima.

In questo caso la figura dell'io avrebbe un comportamento diverso dal ruolo sociale imposto alle donne dalle società in generale. Le donne sono viste come madri, mogli fedeli, ecc, quelle che non fanno parte di questo modello sono giudicate male dagli altri. La donna della poesia sarebbe di quest'ultimo tipo. Questa lettura dipenderà dalla concezione dei ruoli sociali delle donne e degli uomini e ne implica un'inversione. L'io che compare nella poesia è una persona con un atteggiamento provocante e sensuale, mentre il tu compare come una persona insicura. Da questo punto di vista possiamo dire che togliersi gli occhiali in questo caso sarebbe lo stesso che lasciare da parte la formalità, oppure la maschera sociale che determina un comportamento specifico delle persone. La porta e la bocca simboleggiando uno spazio domestico e dell'intimità riguardano un movimento da fuori a dentro la vita dell'io. In questo modo la donna che invita il suo fidanzato a un comportamento diverso (baci disuguali) provoca nel "tu" una reazione di spavento e di sorpresa. Se pensassimo al teatro di successo come simbolo degli applausi e dei rumori, potremmo dire che questi rumori sarebbero proporzionali a quelli dello scandalo causato da un comportamento 
femminile come questo. Sulla base di questa interpretazione possiamo leggere la poesia come una possibilità che una donna esprima i suoi desideri che si realizzano soltanto nel piano dell'ipotesi. Questo viene rafforzato dall'insicurezza del tu che crea una dipendenza espressa anche nella struttura della poesia, cioè, l'apodosi dipende dalla protasi come l'io dipende dal tu perché i suoi desideri siano realizzati. L'immagine del teatro riguarda anche l'idea di rappresentazione dei ruoli sociali e l'idea di fine, perchè gli applausi che risultano dal successo più dei rumori riguardano la fine del pezzo di teatro. Questo senso di fine compare anche nella struttura della poesia attraverso il gioco di ripetizioni della parola successo alla fine della protasi ed alla fine dell'apodosi che riguarda la fine della poesia e la fine della situazione ipotetica.

Compaiono nella poesia punti che citano parti del corpo umano, ad esempio le mani in "bussassi alla mia porta", gli occhi in "togliessi gli occhiali" la bocca in "entrassi dentro la mia bocca" e le orecchie che sentono dire "Amore mio...", questi elementi vengono introdotti in maniera graduale rafforzata dall'uso degli avverbi ora e poi che creano un effetto di successione temporale confermata dalle congiunzioni coordinative additive, questo stratagemma crea un'impressione di un movimento di avvicinamento tra l'io e il tu e di intensità rispetto l'intimità della coppia. Questo aspetto intimo viene rafforzato dall'uso dell'allitterazione della lettera "s" che crea un effetto di sussurro e nello stesso modo si può dire che l'assonanza della vocale "i" fa riferimento all' intensità dell'avvicinamento che cresce piano piano. La concretezza del tu viene rafforzata attraverso l'uso del discorso diretto, cosí l'alternanza delle vocali aperte e chiuse crea l'impressione di un movimento che riguarda un atteggiamento di azione e non azione, questo aspetto può essere un riferimento sia all'insicurezza del tu che all'impossibilità che le donne esprimano i suoi desideri ad alta voce sul piano reale considerando che nella poesia la voce dell'io compare, in questo senso, in mezzo al rumore del teatro e del sussurro.

Così, a partire da questa lettura, si può dire che l'ethos di presenza di questa poesia si definisce come provocante e ambiguo e che la scelta di mettere in scena un tu e non un lui implica l'impossibilità che il lettore identifiche il sesso delle persone che ci compaiono, in maniera che si creano diversi possibilità di interpretazione.

\section{(A5)}

I racconti di trenta righe condotti da un ritmo concitatto e dall'oscurità compongono Navi in bottiglia di Gabriele Romagnoli (1993) in cui il suspense e l'elemento sorpresa alla fine compaiono come stratagemma centrale. L'onorevole doppia chance, tratto da questo libro, sostiene questi aspetti attraverso la maniera impersonale in cui viene narrato il testo figurativo, la ausenza di antroponimi, la introduzione cataforica del protagonista e la fine sorpresa con la sua uccisione.

Sembra che il racconto sia strutturato sulla basi di un movimento di scisione e divisione che riguarda da una parte la forma del racconto e da un'altra il personaggio. Nonostante ci siano spazi definiti come la stanza dell'albergo, i corridoi e lo spazio rappresentato dalla tv e anche una successione temporale segnata dal ritmo veloce delle frase ellitiche e dalle successioni di avvenimenti in:"E adesso, qualche presenza di rito. Cena al Rotary, stasera. Si alza. Stringe il nodo della cravatta nera.", la riattualizazione di quello che viene detto creata dall'uso del tempo presente provoca l'impressione di unione ed anche di annullamento del tempo e dello spazio. Rispetto al personaggio, abbiamo una divisione di immagini: il politico e l'uomo d'onore. Da questa prospettiva si puó dire che questo aspetto riguarda anche il tema centrale del racconto: il rapporto tra politica e mafia. Se da una parte sembra che abbia un'opposizione tra ambedue, da un'altra le isotopie creano un avvicinamento fra questi temi, ad esempio, voti, rielezione e la propria parola onorevole che riguarda la politica, contiene al suo interno il termo onore che può essere relazionato agli uomini d'onore che fanno parte della mafia. Rispetto la scisione possiamo osservare la mescolanza delle voci del narratore e del protagonista e la mescolanza delle risposte dell'Onorevole ai giornaliste e del suo pensiero attraverso il discorso riportato."Denuncia senza rumore." "Faremo i nomi dei collusi."

E interessante notare che il doppio fa sí che il protagonista venga messo in scena come osservatore di se stesso. "Buffo essere nella stanza di un albergo di Palermo e vedersi in tv..." La stessa idea può essere osservata rispetto il narratore il cui compare come osservatore del personaggio ma anche dimostra conoscere il suo pensiero."E certo il capofamiglia non sa che lui e D'ottavio hanno un accordo."

\section{(A6)}

La metapoesia di Sebastiano Vassali intitolata "La poesia oggi" segnala il ritmo veloce della vita moderna, l'eccesso di stimoli che riguardano il quotidiano di coloro che hanno perso la sensibilità per accorgersi della bellezza che ce n'è attorno. Parla dell'indifferenza delle persone nei confronti della poesia, loro la vedono e non riescono a guardarla. Queste sono le prime impresioni che abbiamo dopo aver fatto la prima lettura. In un secondo momento, si stabiliscono due piani temporali i cui riguardano il presente ed il passato della poesia in maniera che la figura del poeta rappresenta il ponte che collega questi momenti. In questo senso, la poesia non è definita, ma soltanto indicata nel mondo di ieri e di oggi nel tempo e nello spazio. 
Nonostante la poesia sembri una prosa, ci sono elementi che ci fanno rifiutare quest'ipotesi, come la punteggiatura, il cambiamento di persona, l'alliterazione della " $t$ " e della "s", l'assonanza, l'eliminazione della "e" in "risciacquar", la rima (lontano / toscano e vinello / suggello nella quinta e sesta strofe rispettivamente), le figure e la struttura in enjabemant che causerebbero uno stragnamento in una prosa. Questi elementi attirano l'attenzione per l'argomento centrale della poesia: l'opposizione tra la poesia di oggi e quella del passato.

Anche se la poesia viene divisa in quattro strofe, si può fare una nuova divisione tematica la cui prima parte, dal primo al sesto verso, corrisponde all'introduzione del tema riguardo la poesia oggi e la funzione del poeta. La seconda parte corrisponde ai luoghi della poesia, dal settimo al quindicesimo verso, a eccezione del decimo, dell'undicesimo e del dodicesimo verso che corrispondono ad una terza parte, la quale possiamo intitolare la poesia classica. All'ultima parte corrisponde l'ultimo verso che tratta l'indifferenza delle persone.

Se nel passato la poesia nasceva "dall'Ideale lontano" instillato nel "cuore del poeta", oggi la poesia nasce impressa in "suggello d'un amore su birra o profumo", compare nelle facce della gente, una massa senza identità che si rivolge verso l'indifferenza e l'indeterminatezza rispetto la poesia. Questo aspetto riguarda un movimento che va dalla determinatezza all'indeterminatezza della poesia nel mondo attuale che compare in diversi momenti nella poesia, come per esempio, l'uso dell' infinito nell'ultima strofa, che può essere inteso come l'indeterminatezza della poesia nel presente oppure l'indeterminatezza della gente all'ultimo verso. Nello stesso modo, si può osservare nei riferimenti allo spazio un movimento dal tutto allo spazio specifico.

"Ci sono persone ovunque, anche in questo paese,

Che siedono attorno a 'tavole rotonde'..."

Se si considera, in questa prospettiva, che la poesia oggi è dappertutto, nei grandi magazzini, nei settimanali illustrati, nella pubblicità al cinema, nelle facce della gente, si può dire che l'io introdotto nella poesia fa una critica alla fugacità della poesia e al carattere commerciale che n'è assunta nell'attualità. In questo senso, sembra che la poesia faccia riferimento al consumismo della società. Quest'immagine raggiunge il punto massimo nell'ultimo verso attraverso la scelta lessicale e l'uso del discorso diretto che può rappresentare sia l'osservassione di qualcuno verso l'indifferenza della gente nei confronti della poesia che una voce dal di fuori che indica una deposizione.

"- La gente guarda e tace, entra al supermercato."

Il tempo principale della poesia è il presente. L'uso di questo tempo associato all'uso degli elementi deitici, come per esempio, la ripetizione dell'avverbio di tempo "oggi" crea una riattualizzazione del tema. Questa poesia è stata pubblicata nel 1972, però l'assenza di elementi puntuali e la scelta temporale ci permette questa possibilità. In questo senso, si può dire che in opposizione al presente, il passato remoto indica un distacco di un ideale di poesia irraggiungibile rappresentato dalle figure delle famose cortigiane. Quest'immagine di un ambiente insolito, aulico che rispecchia la poesia classica viene rafforzata simbolicamente dall'uso di elementi grafici como per esempio, l'uso delle lettere capitale e dalla sintasse lineare che viene interrota da un'inversione che si assomiglia alla struttura arcaica in

"...Che instillarono nel cuore del "poeta"l'Ideale lontano, per cui in milioni morirono o delirando vissero

Passare dalla saponetta al vinello toscano..."

Un altro aspetto interessante è che la ripetizione della parola poesia in posizione strategica in maniera che parola poeta comparisca al centro riguarda sia il fatto che è dallo sguardo del poeta verso il mondo che nasce la poesia, che lo svuotamento di significato della poesia e della funzione del poeta oggi. In questo senso, l'uso delle virgolette dimostrano un distanziamento tra la poesia di oggi e quella lontana, che in realtà corrispondono alla stessa cosa però la differenza è in chi la vede e come la vede. C'è un bisogno di avvicinarsi per riconoscerne il valore.

\section{ALUNO B}

(B1)

Questo testo è basato su due elementi contrapposti: la buona memoria, un elemento positivo, e la dimenticanza, un elemento negativo.

Luca è il nome del protagonista. Aveva una memoria d'elefante, ma adesso è un colabrodo, con appena trent'anni. Come non ricorda un nome, Luca fa un pacto con il destino. Lui parla: "Se non mi viene in mente (il nome) prima delle sei, allora morirò entro un anno". Allora, lui si ricorda del nome alle sei spaccate. Più tardi: un'auto lo travolge.

\section{(B2)}

Nella mia prima lettura questa poesia mi ha sembrato strana, perchè i versi sono corti (Ha partorito/ sono partito), c'è il discorso diretto, ma con dialogi rapidi, con pochi paroli (Come va?/ Non c'é male). Allora, ho visto che il tema 
principale di questa poesia è la diferenza del universo maschile e feminile, la separazione, l' abbandono, infine, le unione sventurati, ma visto freddamente, senza sentimento (Come va?/ Va. Ma/ ho lasciato anche lei,).

L'io poetico è un uomo che ha perduto sua prima moglie (Come è andata?/ È andata/ via ...) e ha lasciato sua seconda, ma vede la sua situazione con molta ironia. C'è in questa poesia altre tre personaggi: la prima moglie (Ha partorito), la seconda Ho lasciato anche lei)e un'altra, forse un amico del personaggio principale, che partecipa della narrazione, quando lo chiedono sui matrimoni di lui (Come è andata?), (Come va?). I risposti sono ironici, l'io poetico gioca con il doppio significato del verbo andare ("Come è andata", nel senso di sentimento e "È andata via", nel senso di movimento), usa anche il doppio gioco dei due piani temporali del presente e del passato (ho lasciato anche lei/ parto alle sei).

La poesia c'è anche rima (lei/ sei; ospedalle/ male; va/ma) alliterazione (ospedalle/ sposata), e ha una cadenza rapida, nella mia otica per dimostrare la indiferenza dell'io poetico con i matrimoni e la sua disillusione con le donne.

\section{(B3)}

Il racconto "Occhi di Paola", scritto da Gabriele Romagnoli è tratto da "Navi in bottiglia". Come tutti gli altri racconti di questo libro, "Occhi di Paola" è un testo di poche righe, con una narrazione rapida. L'autore introduce il protagonista maschile cataforicamente, attraverso dell'uso del pronome direto atono "lo". "Qualcosa lo tormenta". Il racconto comincia in media res e così la storia è accelerata, creando un efetto di curiosità e di atenzione. Le frasi sono quasi sempre brevi, "È per quel pomeriggio" e l'autore usa diversi elementi per dare un senso di verità alla storia, come possiamo identificare nell'uso: primo, degli antroponimi, rivelando i nomi dei personaggi, Duccio, Paola, Franca, e Giorgio; secondo, del tempo al presente, che ci avvicina dei fatti "Guarda Paola e vorrebbe urlare"; e terzo, del discorso diretto, che concreta la "realtà" dei personaggi "Ho avuto un incubo". Oltre a ciò, l'autore descrive fisicamente il personaggio di Paola, di cui gli occhi si prestano a dare il titolo al racconto.

Il piano concreto, tuttavia, non è il più importante del racconto. Il suo tema principale è la coscienza davanti il tradimento e, per questo motivo, 1 a storia ha diversi elementi soggetivi. Vediamo la struttura narrativa. La storia è narrata in terza persona, da un narratore osservatore, che include il lettore in questa osservazione, quando usa il tempo presente. Inoltre, lui non solo dà voce ai personaggi con il doscorso diretto, come include i suoi pensieri nella narrazione, quando non usa le virgolette. Questo stratagemma è usato in un momento molto importante della storia, quando abbiamo la frase ognitemporale: "Si può tradire e farla franca, anche con se stessi. Si può tranquillamente convivere con i propri peccati". L'autore ha scelto di non usare le virgolette in questa frase per generalizare queste idee, per tornarle valide per tutti. Ma sará che queste idee siano efetivamente valide nel racconto? Vediamo...

Possiamo notare dapprima che il racconto possiede diversi elementi contrapposti, come occhi grigi ed occhi azzurri, oscurità e luminosità, che sono associati a sensi astratti, come punizione ed assoluzione, peccato ed innocenza, ecc. Questi elementi rivelano il gioco mentale che c'è nella storia, tra la colpa e la coscienza tranquilla. E possiamo credere che tra queste due condizioni mentali, quella che regna nella coscienza del protagonista è la prima, per alcuni motivi: verso la metà del primo paragrafo c'è un cambiamento temporale importante nella narrazione, dal presente al passato remoto. "E d'improviso capisce. È per quel pomeriggio. Esatamente vent'anni prima". A partire da questo momento, quando il protagonista ricorda il suo tradimento, il tempo verbale usato dal narratore é proprio quello che non ha nessuno legame con il presente, dimostrando, quindi, una lontananza psicologica tra il personaggio e la sua azione, cosciente o no. Tuttavia, quando il narratore dice che Duccio non ha tradito dopo di quel giorno, usa il passato prossimo, "non l'ha più fatto", questo sì legato al presente. È plausibile, quindi, che il tradimento ancora incomodi la coscienza di Duccio, il che contradice la frase ognitemporale.

Ma questo gioco mentale solo ocorre con il protagonista? È più probabile che no, perchè siamo analizzando un racconto del "Navi in botigglia", e sempre troviamo qualcosa di sorprendente alle righe finale. Vediamo il legame tra la coscienza e il piano materiale creato dal racconto. "Non può dormire. Qualcosa lo tormenta". Il protagonista non dorme quando qualcosa lo tormenta, il che è rinforzato dall'avvenimento "lui si addormentò subito", dopo di lui tradire la moglie e non sentirsi colpevole. Dopo, il protagonista racconta alla moglie il suposto "incubo" e, nuovamente tranquillizato, si addormenta. Qui il legamento semantico è già concreto. Con questo senso di che non si convive così facilmente con i propri peccati, come abbiamo potuto vedere nelle azioni del protagonista, e questo legato alla capacità di dormire, quale sarà il significato di essere Paola, alla fine del racconto, di occhi aperti, senza dormire? Avrà lei la coscienza colpevole? Di che?

Io, personalmente, credo che anche Paola ha tradito.

\section{(B4)}

La prima cosa che possiamo osservare in questa poesia di Patrizia Cavalli, trata dal suo libro "Poesie", è la congiunzione condizionale "Se", l'unica parola scritta con maiuscola. Ci viene subito in mente la costruzione del 
periodo ipotetico, quello che si compone da una protasi, che costituisce una condizione, e da un'apodosi, che costituisce la conseguenza di questa condizione. E, infatti, tutta la poesia è strutturata in questo periodo.

Un io, pressuposto da un $t u$ che viene scritto già nel primo verso, gli dice che se bussasse alla sua porta, se tutte e due togliessino i loro occhiali e se il $t u$ gli baciasse, chiedendole cosa gli succedeva, "sarebbe un pezzo di teatro di successo". Da questo "sarebbe" possiamo concludere che il periodo ipotetico ora osservato è quello della possibilità. Abbiamo, dunque, fino alla metà dell'ottavo verso, la prima parte del periodo, composto di queste condizioni, e soltanto la seconda metà dell'ottavo verso e l'ultimo, la conseguenza. È interessante notare che tanto la prima come la seconda parte finiscono con la parola "successo", la prima, il partecipio del verbo succedere, e la seconda, il sostantivo. È come se avessimo una rima speciale, dentro la poesia.

Lo spazio del testo è molto interessante. C'è una porta tra l'io ed il $t u$. L'io è dentro un spazio privato, e vuole che il $t u$ entri dentro questo spazio. Quest'idea è rafforzata quando l'io chiede al $t u$ di entrare dentro la sua bocca, ossia, un spazio ancora più privato, il suo mondo interiore. Non abbiamo, però, gli antroponimi, così non possiamo sapere chi sono i due personaggi, il loro sesso, la loro età, ecc.

Da qui, entriamo nella parte interpretativa del testo. Chi sono l'io ed il tu non sapiamo; sapiamo soltanto che l'io vuole un avvicinamento del $t u$, che può succedere o no. Qualcosa succede nel mondo privato dell'io, perchè l'io vuole che il $t u$ glielo chieda. Il $t u$ non percepisce questa disarmonia interiore? Non ci credo. Penso che il tu non entri nel mondo interiore dell'io per paura. Paura dei "baci disuguali", giacchè esteriormente sono armonici, hanno occhiali uguali. Pensiamo adesso: gli occhiali degli uomini non sono diversi di quelli delle donne? Non saranno loro, dunque, dello stesso sesso? Non sarà questa la paura del $t u$, dei baci disuguali, se pressuponiamo che i baci uguali sono quelli più comuni, che vediamo tra un uomo e una donna?

Siccome questo testo è stato scritto da una donna, e come sapiamo, atraverso la sua biografia, che lei è lesbica, seguiamo la nostra analisi partendo da quest'idea, ossia, di un rapporto tra due donne.

Un rapporto omossessuale non è, ancora oggi, considerato "normale" da maggior parte delle persone. Così, i desideri di amore omossessuale di un uomo o di una donna é, molte volte, nascosto, proibito, quando no, segreto. E non è questo l'argomento di questa poesia? Un desiderio nascosto dell'io? Possiamo osservare che l'io non parla direttamente con il $t u$. Il $t u$ è immaginato dall'io. Non ha presenza reale nel testo. E l'immaginazione dell'io cresce pian piano. Vediamo come.

Ci sono nel testo due avverbi di tempo. Un "ora", nel primo verso, e un "poi", nel quarto, tutti e due nella prima parte del periodo ipotetico. E ogni verso dopo il primo comincia con la congiunzione aditiva "e", meno il quinto, che comincia con un "senza". Abbiamo, dunque, una piccola seguenza narrativa, che è, allo stesso tempo, una seguenza di ipotesi, di condizioni. I tre primi versi rappresentano le cose che potrebbero succedere "ora". Il "poi" ci porta a un tempo un pò più lontano, il che significa una ipotesi ancora più difficile di succedere (il bacio e la domanda).

Nonostante l'io voglia che queste cose diventino verità, non sembra di crederci. Lo possiamo dedurre dal paragone che l'io stesso fa di questa situazione ipotetica con un pezzo di teatro. Ricordiamo che, generalmente, nel teatro succedono cose meravigliose, ma lontane della vita normale delle presone, senza eroismi, senza molta poesia. Il desiderio dell'io, dunque, è molto forte, ma difficile di realizzarsi. L'io pensa nel $t u$ fino a presentificarlo atraverso un discorso diretto, il che rafforza allo stesso tempo l'aspetto teatrale della poesia. Ma in che modo, nel modo astratto, platonico? Vediamo cosa possiamo capire del desiderio dell'io atraverso le immagini trovate nella poesia che si riferiscono al corpo umano.

Ci sono nella poesia un sacco di riferimenti alle parti del corpo. Le mani, indirettamente, nel busssare la porta e nel togliere gli occhiali. Possiamo immaginare le mani come le rappresentanti dell'azione, del fare le cose, responsabile per l'avvicinamento delle due donne. Gli occhi, come rappresentante dell'anima - ricordiamo questo detto: 'l'occhio è la porta dell'anima" - nascosti dietro agli occhiali, ossia, le maschere sociali. E la bocca come rappresentante del piacere fisico, del sesso.

Abbiamo qui, dunque, un desiderio di avvicinamento totale, di corpo e di anima. Quasi un'adesione del $t u$ nell'io, formando un solo essere. La problematizzazione della poesia, però, è l'impossibilità sociale di questo rapporto, dentro questa linea interpretativa, evidentemente. Possiamo verificarla atraverso le aliterazioni in ss, che abbiamo in tante parole come bussassi, togliessi, dicessi, baciasse, entrassi: da un lato significano il suono del sussurro, che ci porta al mondo del segreto, all'atmosfera del nascosto. Dall'altro, il suono sibilante della serpente, rappresentante, nella Bibbia, del pecato femminile, del desiderio sessuale. Insomma, per tutto questo, una volontà dell'io che rimane dramaticamente, anche in senso letterale, nel mondo del Se.

\section{(B5)}

Così come tutti i racconti del libro "Navi in Bottiglia", di Gabriele Romagnoli, "L'onorevole doppia chance" è breve, ma pieno di dettagli. Il tema del racconto è quello del rapporto tra mafia e politica. Il personaggio principale è un 
deputato che fa parte della commissione antimafia, ma che, allo stesso tempo, ha un accordo con la mafia stessa. Possiamo osservare, dunque, che questo testo è figurativo, e crea un effetto di realtà.

I temi del racconto sono la politica e la mafia, ma non solo. Possiamo osservare dalle scelte lessicali dell'autore che compare nel testo il tema dei mass midia e, dietro tutto questo, la questione del doppio. La parola del titolo, "onorevole", è quella che scatena tutti questi temi. Da una parte significa deputato, dall'altra, viene dalla parola "onore", il che ci fa ricordare la mafia, a causa degli "uomini d'onore". Nel testo abbiamo anche un sacco di isotopie che entrano in relazione con i temi, come per esempio: vicepresidente, voti, rielezione, preferenze (politica); Cosa Nostra, famiglia, cosche (mafia); TV, radio, giornalista, intervista (mass midia); ed anche cravatta nera o cravatta rossa, doppia chance, scapattoia, accordo, ubiquità (il doppio).

Quest'ultimo tema, la doppia vita dell'onorevole, è rafforzato dal modo in cui l'autore costruisce il testo. La doppia vita del protagonista è rappresentata nel testo concretamente, atraverso lo spazio, anche lui, doppio: da un lato abbiamo l'albergo, dov'è l'onorevole. Dall'altro, la TV, dove lui parla con i giornalisti, facendo finta di essere onesto. E lui si vede in TV, poi si ascolta in una radio. Per questo abbiamo nel testo alcuni verbi riflessivi, come ascoltarsi e vedersi, anche queste parole isotopie del tema del doppio.

Il nome del protagonista non viene detto. Lui è introdotto nel testo in modo cataforico. Le frasi sono brevi, assindetiche. Il tempo principale del racconto è quello del presente, il che crea un effetto di aspettativa e avvicina il lettore della storia. Tutto questo rafforza l'idea della vita dinamica e pericolosa dell'onorevole.

Alla fine l'onorevole è ucciso nel corridoio dell'albergo, da un sicario. La sua voce, nella radio, dice ancora una enorme bugia, che lui temeva di più per le sorti dei valori che rappresentava che per la propria vita. In realtà, non rappresentava nessun valore.

Va detto che questo effetto ironico, quasi comico, è creato dal narratore, perchè è lui che sceglie le disposizione delle azioni. E il testo ci sembra ancora più ironico quando osserviamo il narratore. Si vede che lui si avvicina del protagonista, riproduce i suoi pensieri, permette che l'onorevole sia sicuro di sè, deciso, permette, insomma, che lui sorrida della vita. Finchè, ad un tratto, lo uccide, affinchè noi, i lettori, ridiamo di lui.

\section{(B6)}

Questa poesia di Sebastiano Vassali è stata pubblicata nel 1972. Il suo titolo, però, è La poesia oggi. Possiamo dire che questo elemento deitico, oggi, riesce ad riattualizzarla? Le cose dette da Vassali potrebbero essere dette oggi? Vediamo cosa dice la poesia, prima di tutto.

La poesia oggi è suddivisa in quattro strofe di quattro versi ognuna, ma tematicamente si potrebbe suddividerla in tre universi: quello della critica letteraria, dal primo verso della prima strofa al secondo verso della seconda strofa; quello della letteratura moderna, dal terzo verso della seconda strofa in poi, però, con un taglio alla terza strofa, dal primo al terzo verso, che ci apre l'universo della letteratura classica.

Il primo universo rappresentato nella poesia è quello della critica letteraria. L'io della poesia lo introduce nel modo impersonale: "Ci sono persone, ovunque", "che siedono", "che prendono", "che scrivono". Questo ci fa pensare che l'io non fa parte di questo gruppo, proprio perché quando dice che queste persone scrivono sulla "poesia oggi" e sulla "funzione del poeta", "risponde" che non sa dire nulla rispetto alla funzione del poeta, e che può soltanto indicare la poesia, dire dove si può trovarla. L'uso delle virgolette per le "tavole rotonde" crea anche, secondo me, un effetto dispregiativo a questo universo.

Quando comincia a indicare il luogo della poesia, l'io ci porta all'universo della poesia moderna. "Sta nei grandi magazzini, nei settimanali illustrati, nella pubblicità al cinema, nella face della gente". Quest'ultimo elemento, però, "faccia della gente", apre un taglio nella poesia: la gente vede le famose cortigiane passare dalla saponeta al vinello toscano, all'abito già pronto, ecc, e proprio quando cita le cortigiane, entra nell'universo della poesia classica: il lessico cambia: "instillarono nel cuore del "poeta' l'Ideale lontano" e la sintassi cambia, avvicinandosi allo stile latineggiante: "milioni morirono o delirando vissero". Oggi (e questo oggi vale veramente per il 72 e per il 2006), queste belle donne sono nella pubblicità, "sturando un lavabo", "stampate su birra e su profumo", ecc. L'uso di queste parole "basse", come "risciacquar" (e l'effetto ironico di togliere la $e$ finale per tornare 'poetica' la parola), fa sì che questo mondo moderno sia visto, anche lui, in un modo dispregiativo.

Questo gioco spaziale (da un lato le "tavole rotonde" sterili della critica letteraria e il mondo di consumo automa e indifferente e dall'altro il mondo classico, romantico) e temporale (da un lato il presente, e dall'altro, il passato "lontano", nostalgico) fa sì che la poesia sia divisa in due: l'oggi, sterile, e lo ieri, pieno, dal punto di vista artistico. Possiamo osservare, per esempio, che il mondo della poesia d'oggi, dentro il testo, sia quello di consumo che quello intellettuale, non ha passione. Il mondo moderno è così automa che chiede a se stesso qual è la "funzione" del poeta. La questione della "funzione" è moderna, legata in gran parte al mondo del lavoro, del capitale, dell'utilitarismo. Mentre invece il mondo antico è pieno di "passione", di "delirio", di "morte", di "Ideale". E sono proprio le cortigiane, che a quel tempo erano la materia della poesia classica e oggi sono oggetto di consumo, le figure centrali 
per l'interpretazione della poesia, perché legano il mondo antico a quello moderno. Se instillavano l'Ideale nel cuore del poeta (e la gelosia, forse, nei cuori delle altre donne), oggi sono banali, stampate nei prodotti e guardate dalla gente che "tace" e "entra al supermercato", ossia, che non sente, che non si apassiona più, che non ha più un'anima. La ripetizione delle parole poeta e poesia nel testo, penso io, insieme a questa divisione in due mondi, crea un effetto di svuotamento, non della poesia stessa, che c'è, ma dell'anima della poesia. Voglio dire che la materia della poesia antica era l'anima, il cuore, ossia, la passione, che nasceva specialmente attraverso le donne. Se oggi l'anima, il cuore, la passione, non ci sono, e se ci sono soltanto il consumo, l'indifferenza, l'automatismo, dove si può trovare la poesia? O meglio: di che cosa può parlare la poesia? Penso che la risposta a questa domanda venga data dalla propria poesia di Vassalli: la poesia parla di sè stessa, discute sè stessa. Non riesce più a fare altro, così come la letteratura contemporanea in generale, finché la gente guardi e non taccia, finché la gente riscopra che ha un cuore, che ha un'anima capace di delirare e di morire per amore. E mentre lo fa, è frammentaria, organizzata straneamente, apparentemente senza regole, perché possa dimostrare dentro sè stessa la condizione del mondo attuale.

Va bene, però, ormai sono tutti al supermercato, e si ridono di chi sceglie il mondo delle Lettere, senza "funzione". Dobbiamo piuttosto aspettare.

\section{ALUNOC}

\section{(C1)}

Luca aveva una memoria molto buona, ma adesso con appena trent'anni, non ce l'ha più, specialmente per i nomi. Primo lui cerca di recordare il nome di un calciatore del Milan e poi di un compagno delle media. Cammina nella sera di Milano e da due ore si tormenta. Lui è ossessionato e fa un patto con il destino per ricordare il nome: se non ricordare prima delle sei, lui morirà entro un anno.

Lui ha quindici minuti per ricordare, fa una ressegna di lettere dell'alfabeto e guarda l'orologio. La situazione crea una tensione.

Lui ricorda del nome: "Tortello". Guarda l'orologio, le sei spaccate!

Un'auto lo travolge nella strada.

\section{(C2)}

Le mie prime impressioni sulla poesia sono di tristezza e stranezza. Dopo da seconda lettura possiamo osservare che la poesia "parla" dell'abbandono, della separazione, della differenza del universo maschile e femminile.

Nella poesia ci sono tre "attori" che parlano. Nel secondo verso, sono partito, noi posssiamo identificare l'io. Nel quinto verso, Non c'è male, possiamo identificare la sua prima moglie e nei versi Come è andata? e Come va? possiamo identificare forse un suo amico.

L'io poetico è sposato due volte. Nel primo matrimonio sua moglie ha partorito e è andata via e nel secondo matrimonio lui lascia sua moglie. Ma l'io non è triste ma sarcastico. Le sue risposte sono sempre ironiche.

Lui usa diversi stratagemmi nella poesia per creare l'effeto di umore, come per esempio il doppio giocco dei due piani temporali, passato e presente, come nei versi Ma ho lasciato anche lei / parto alle sei.

Tutta la poesia ha un tono ironico. Quando l'amico domanda Come è andata?, il "io" gioca sul doppio significato del verbo "andare", È andata / via. Il verbo "andare" può essere usato come nel verso sono andato all'ospedale o come nel verso Come è andata? Il primo caso indica movimento e il secondo caso può essere sostituito per "Come stai?" Pertanto la risposta dell'io crea un effeto ironico, di umore, giacchè lui non parla "È andata bene." per esempio, e sì É andata /via.

Del punto di vista formale, la poesia ha quattordici versi, alcune alliterazione come ospedale e sposata; e rime come ospedale e male, allora e ancora e lei e sei. Il discorso diretto crea um effeto di realtà giacchè il dialogo é riportato veramente, come per esempio nei versi Come va? / Non c'è male. Lui monstra anche per discorso diretto che i suoi matrinoni sono male, come per esempio nei versi Come è andata? / ̇̀ andata / via. e Come va?/Va.

Forse possiamo capire la poesia come uma critica divertente rispetto a tutte le donne o al matrinonio.

\section{(C3)}

Possiamo dire che il titolo del racconto, Occhi di Paola, è un po'enigmatico - come è enigmatica l'immagine degli occhi di una persona. Oltre a ciò, il colore degli occhi di Paola è la grande metafora e la chiave del racconto, il cui tema è il tradimento e le sue conseguenze psicologiche.

L'inizio del testo è molto interessante, giacchè il protagonista, Duccio, è presentato cataforicamente attraverso l'uso del pronome diretto atono lo. Non si sa perchè lui non puó dormire e che cosa lo tormenta. Questo crea anche un effetto di curiosità ed aspettativa che trattiene il lettore e lo fa continuare a leggere. 
Il narratore parla in terza persona e conosce i pensieri e la vita del protagonista. Duccio è marito di Paola e non riesce a dormire perché la sua coscienza lo tormenta. Lui, venti anni prima, ha tradito Paola con Franca, la moglie del suo amico Giorgio; ed attraverso il narratore possiamo osservare la colpevolezza, l'inquietudine ed il pentimento del personaggio.

Il narratore è un osservatore che vede e narra, lui usa il presente e sembra che include il lettore usando questo tempo verbale. Questa è una strategia dell'enunciatore per costruire l'effetto di senso della veritá e dell'oggettività nel testo. Anche l'uso del discorso diretto e degli antroponimi, che specificano i personaggi, creano anche un'illusione di realtà.

C'è un momento nel testo in cui l'enunciatore interrompe la narrazione ed inserisce, senza usare le virgolette, un pensiero di Duccio, cosicchè la battuta del personaggio si confonde con quella dell'enunciatore. In questa frase il narratore parla al presente onnitemporale.

L'enunciatore usa anche due tempi del passato, che sono molto importanti in questo testo perchè aiutano a spiegare quello che Duccio pensa del tradimento. Quando l'enunciatore usa il passato remoto - che è il tempo della storia per raccontare un'azione, lui si riferisce ad un'azione "lontana" e che non è più rilevante per il presente. Lui usa questo tempo nel frammento in cui racconta il tradimento. Ma quando l'enunciatore usa il passato prossimo - che è il tempo direttamente legato al momento dell'enunciazione - significa che quello che il personaggio dice, è rilevante per il presente. Lui usa questo tempo nel frammento in cui Duccio parla del tradimento: "Non 1'ha più fatto".

Ci sono alcuni aspetti semantici che sono importanti. L'enunciatore ha creato una grande metafora con il colore degli occhi di Paola: azzurro x grigio. Possiamo dire che questi due colori sono semanticamente opposti. L'azzurro può rappresentare l'innocenza, la tranquillità, la luminosità, il cielo, la pace, la coscienza tranquilla, la verità; e il grigio invece, può rappresentare il peccato, la colpevolezza, l'oscurità, un temporale ed il rimorso.

Nel frammento "Nell'oscurità gli occhi di Paola sono aperti. Un po' meno azzurri, un po' più grigi" possiamo osservare un cambiamento di colore. Sappiamo che l'azzurro è un colore primario e il grigio è la mescolanza del nero, che è il buio totale, e del bianco, che è la luminosità. Allora, possiamo dire che Paola rappresenta la purezza iniziale che è avvolta da un fumo oscuro della menzogna.

\section{(C4)}

Sappiamo che in un testo, tanto narrativo, quanto descrittivo o argomentativo, ogni parola è scelta con attenzione per creare alcuni effetti e colpire il lettore. Credo che nella poesia il lavoro sia un pò più meticoloso giacchè quest'espressione dello stato d'animo dell'autore appare in maniera più densa e sintetica. Possiamo osservare già nel primo verso della poesia di Patrizia Cavalli l'importanza degli elementi scelti che ci fanno pensare a vari riferimenti possibili come le persone, lo spazio e la situazione.

La poesia comincia con un "Se" che introduce un periodo ipotetico - in questo caso della possibilità - guidando così la nostra lettura. Il verso continua con l'avverbio di tempo "ora" che indica un momento di riferimento presente proiettato in un'ipotesi futura e dopo con sequenza "tu bussassi alla mia porta", in cui appare un "tu" che pressupone un "io", un congiuntivo imperfetto che conferma la seconda persona e dà alla poesia un tono più soggettivo, il possessivo "mia" che esplicita l'io e il sostantivo "porta" che ci dà un'idea di spazio.

Dopo aver letto gli altri versi è possibile dire che la poesia può essere divisa in due parti a partire della congiunzione "Se": la protasi, che costituisce la condizione e l'apodosi che, invece, è la conseguenza di questa condizione. È interessante osservare che tutte e due finiscono con la parola "successo" usata in modo diverso, partecipio passato del verbo succedere e sostantivo. Forse questo stratagemma crea un effetto di conclusione nelle due parti, mentre un altro aspetto interessante è che l'io ed il tu compaiono soltanto nella protasi.

Il tema della poesia è un rapporto amoroso non realizzato, una scena ipotetica fatta dall'enunciatore. C'è un "io" che parla con un "tu" immaginato in maniera intima ma non è possibile dire con certezza chi sono, giacchè nella poesia non ci sono indicazioni di maschile e femminile. Ma credo che non ci sia bisogno di specificare, la costruzione della scena e le immagini scelte sono le cose che colpiscono il lettore.

Mi pare che due figure in particolare siano interessanti, gli occhiali e la bocca. Forse gli occhiali rappresentano l'armonia nel mondo esterno mentre il bacio rappresenta la disarmonia nell'interno di ognuno. La bocca che, secondo me è anche una specie di porta che limita due spazi, è l'elemento che unisce l'io e il tu. Quando le porte si aprono e si uniscono senza temere le differenze succede uno scambio di sentimenti e desideri. La bocca rimette anche al gusto e gli occhiali alla vista, siccome il verbo bussare rimette al tatto e il verbo dire all'udito. Questi riferimenti ai sensi del corpo umano rendono la poesia più carnale e meno sublime.

Secondo me la poesia ha un forte aspetto teatrale. La descrizione degli avvenimenti successivi nella protasi sembrano indicazioni che un regista fa ai suoi attori, così possiamo pensare che l'enunciatore regge il suo desiderio persino introducendo la battuta del "tu". Nel discorso diretto "Amore mio, ma che è successo?" è come se il tu immaginato 
acquistasse più concretezza e entrasse nell'immaginazione dell'io mostrando sorpresa nei confronti di una situazione inaspettata.

Sul piano dell'espressione è possibile osservare alcuni stratagemmi come l'allitterazione della consonante "S" che crea l'effetto di un sussurro sensuale, la rima tra parole come "occhiali", "uguali" e "disuguali" e la ripetizione della congiunzione "e" che rafforza la successione di avvenimenti.

\section{(C5)}

In L'onorevole doppia chance tratto da Navi in bottiglia, di Gabriele Romagnoli, possiamo osservare a partire già dal titolo un aspetto fondamentale che sarà lo scheletro del testo. Dopo aver analizzato il racconto è possibile notare che il tema del doppio si manifesta in diversi modi, attraverso il protagonista, la voce del narratore, lo spazio, nelle isotopie e persino le scelte temporali dell'enunciatore.

Siccome si tratta di un testo figurativo in cui la situazione concreta crea l'effetto di realtà, possiamo cominciare riguardando alcune figure (termini concreti) che hanno rapporti con i temi identificati. La politica si manifesta attraverso isotopie come Onorevole, voti e rielezione; rispetto alla mafia ci sono dei termini come antimafia, Cosa Nostra e cosche; rispetto ai mass-media compaiono delle figure come TV, giornalista, intervista, spettatori; il doppio si manifesta attraverso i termini come doppia vita, doppia chance, cravatta nera, cravatta rossa e ubiquità. Nel titolo il doppio viene espresso in maniera diretta attraverso l'uso della parola doppia e in maniera ambigua attraverso lo scatenatore di isotopie onorevole che può indicare tanto il sostantivo legato alla politica quanto l'aggettivo legato alla mafia.

L'attorializzazione, la temporalizzazione e la spazializzazone definite dall'enunciatore hanno un ruolo fondamentale nello sviluppo narrativo dei sensi del testo. Vediamo in che modo il doppio compare in tutte e tre.

Rispetto all'attorializzazione, cioè a tutto quello che si riferisce alle persone, abbiamo un personaggio principale e quelli secondari, e poi il narratore e l'enunciatore. Il protagonista viene introdotto in maniera cataforica, l'inizio del testo è impersonale e soltanto dopo si é fissa la terza persona singolare lui. Il suo nome non è citato ma sappiamo che è deputato, vicepresidente della commissione antimafia (ruolo sociale) e allo stesso tempo ha un accordo con la mafia. Il narratore lo descrive come un uomo sicuro che ha uno sguardo deciso, caratteristiche positive per chi ha una doppia vita, giacché trasmettono sicurezza. I personaggi secondari non sono specificati, ci sono dei giornalisti che parlano e soltanto D'Ottavio, nemico delle cosche con il quale L'Onorevole ha anche un accordo, ha un nome, però non parla.

Il testo è narrato da un narratore osservatore in terza persona che nonostante non sia onniscente conosce i pensieri dell'Onorevole. Questo fatto dà anche a lui un carattere doppio creato dall'ambiguità dei discorsi indiretti liberi. Lui racconta la storia al presente, tempo oggettivo e concomitante rispetto a un momento di riferimento presente che crea l'illusione di parlare in presenza, l'effetto d'aspettativa nel lettore e una riattualizzazione ad ogni lettura.

L'enunciatore è concitato, scrive in modo paratattico usando frasi brevi ed ellittiche, il che rende il testo più dinamico e rafforza l'aspettativa.

Rispetto alla temporalizzazione che riguarda tutto quello che si rifesrice al tempo dell'enunciato, viene usato il presente (tempo della narrazione), il congiuntivo imperfetto, il futuro, il passato prossimo e l'infinito e il gerundio, che rafforzano il carattere doppio del testo giacché possono creare ambiguità, possono indicare azioni concomitanti come nel frammento sorride ascoltandosi rispondere o possono rappresentare il doppio più simbolicamente con l'uso dei verbi riflessivi. Per esempio, quando l'Onorevole si vede e si ascolta rimane di fronte alla sua altra faccia. Rispetto alla spazializzazione che si riferisce allo spazio obiettivo dell'enunciato abbiamo l'albergo e la TV ed anche questi rappresentano il doppio. Nella stanza dell'albergo lui si vede e si ascolta, in TV risponde alle domande dei giornalisti; nella stanza lui usa una cravatta rossa, in TV ne usa una nera; nel corridoio dell'albergo lui viene sparato mentre in TV sta rispondendo che teme di più per le sorti dei valori che rappresenta. Il tempo e lo spazio sono citati letteralmente: Come se il tempo e lo spazio offrissero sempre a quelli come lui una scappatoia. La possibilità, addiritura, di vivere una doppia vita. E persino l'inizio e la fine del testo possono rappresentare l'idea del doppio attraverso il buffo e il tragico.

\section{(C6)}

Cosa ci viene in mente dopo aver letto il titolo La poesia oggi? Potrebbe essere un titolo di un saggio sulla poesia contemporanea, per esempio, o il titolo di una composizione scritta da uno studente. La poesia, essendo un'espressione dello stato d'animo dell'io, di solito parla di tematiche più astratte, soggettive, metafisiche.

Sebastiano Vassali, nel 1972, ha scritto la poesia La poesia oggi la cui tematica è la poesia stessa. Sono quattro strofe di quattro versi ciascuna, i versi sono liberi e non ci sono praticamente rime. Rispetto al lessico compaiono espressioni volgari come risciaquar - scritta senza la $e$ per sembrare un registro elevato - e rispetto allo spazio 
possiamo osservare un movimento concentrico nella prima strofa e a partire del verbo indicare nella seconda strofa si parla di spazi del mondo di consumo.

Dopo aver letto questa "metapoesia" possiamo osservare che il poeta non dice infatti cosa è la poesia, ma la indica: Sta nei grandi magazzini, nei settimanali illustrati, / Nella pubblicità al cinema, nelle facce della gente. Ma non lo fa in modo semplice, giacché contrappone il mondo di oggi e il mondo lontano.

Le quattro stofe che compongono questa poesia possono essere divise tematicamente in tre parti. Nella prima (dal primo al sesto verso) il poeta introduce il tema in maniera impersonale e dopo parla in prima persona, nella seconda (dal settimo al penultimo verso) dice dov'è la poesia e nell'ultima parte compare un unico verso che sembra staccarsi dagli altri.

Possiamo osservare che questa suddivisione riporta ad universi diversi. L'universo della critica letteraria viene inserito attraverso gli elementi della prima parte in cui il poeta parla di persone ovunque che discutono la poesia attorno a "tavole rotonde" e che danno premi, mentre gli universi della poesia classica e della poesia contemporanea vengono inseriti nella parte in cui lui parla del luogo della poesia.

Il tempo verbale sul quale è basata la poesia è il presente ma non per caso il passato remoto viene usato dall'autore in due versi. Nella parte in cui lui indica il luogo della poesia possiamo osservare una contrapposizione fra il mondo lontano e il mondo di oggi. Nella maggior parte della poesia il poeta usa il presente e compaiono alcuni elementi enunciazionali che si riattualizzano come l'avverbio di tempo oggi, ma il poeta usa il passato remoto - tempo enunciativo che indica concomitanza a un momento di riferimento, un'allontananza - quando vuole indicare il mondo lontano. Vediamo la terza strofa: Che vede le famose cortigiane, gli animali lussuosi e spelendidi, / Che instillarono nel cuore del "poeta" l'Ideale lontano, / per cui in milioni morirono o delirando vissero, / Passare dalla saponetta al vinello toscano. Ci sono altri stratagemmi che riportano al mondo lontano: la sintassi con i verbi messi alla fine provoca uno straniamento rispetto alla linearità, è una costruzione latinizzante; le uniche rime lontano e toscano si trovano in questa strofa e l'immagine delle famose cortigiane riporta all'ambiente delle corti.

C'è una figura messa tra virgolette "le tavole rotonde" che oltre a rappresentare i due mondi, quello lontano (Re Artù) e quello contemporaneo (critica letteraria) può essere anche interpretata come ironica, così il poeta mette in evidenza l'inutilità della critica letteraria.

Credo che l'ultimo verso - La gente guarda e tace, entra al supermercato. faccia riferimento alla nostra società consumista, indifferente e automatica. Per fare poesia e per capire poesia - oggi e sempre - c'è bisogno di sensibilità, di osservazione, di riflessione. Oggi le facce della gente vede le muse ispiratrice stampate sulla birra o sulla saponetta come dice il poeta. Penso che quest'ultimo verso possa essere un discorso diretto, ma un discorso della coscienza del poeta, che dopo aver scritto tutti gli altri versi si rende conto che è inutile scrivere poesia o parlare di poesia oggi, giacché le persone soltanto guardono, tacciono e entrano al supermercato.

\section{ALUNO D}

\section{(D1)}

Nel testo di Gabrielle Romagnoli è basato su due elementi contrapposti. La memoria d'elefante e colabrodo. L'elemento positivo è la memoria, è ricordare e l'elemento negativo è dimenticare.

Sono due metafore per enfatizzare e crea l'effetto di contrapposizione.

Del protagonista sappiamo che si chiama Luca, ha trenta anni, aveva una memoria d'elefante e adesso non ce l'ha più. Ha fatto un patto con il destino.

Nel racconto ci sono altri personaggi: il destino, Torttelo, la memoria, gli questionatori.

Questo testo ha tre suddivizioni. La prima, che va della prima frase alla frase "ma non vuole darsi per vinto". Questa suddivizione è la presentazione. La seconda va della frase "è sicuro che la memoria non l'ha davvero abbandonato" alla frase "è ossessionato". Questa parte è primo del patto con il destino. La terza suddivizione va della frase "Guarda l'orologio" alla fine del racconto. Questa parte è doppo il patto con il destino.

Il discorso diretto compare nel testo tre volte e questo crea l'effetto di realtà, di verità. Nel racconto ci sono due riferimenti ad Milano e questa città è in Lombardia.

(D2)

Nella mia prima impressione, mi sembra che ha un matimonio che non è justo; lei ha lasciato lui. Doppo, hanno sposato di nuovo, ma in questa volta, lui ha lasciato lei.

Il tema principale mi sembra essere l'universo maschile contro l'universo feminile, per ché la poesia parla di un uomo che è partirto doppo che una donna, probabilmente, sua moglie, ha partorito. Il tema principale può essere acnhe la rivalsa, per ché l'uomo ha sposato con una donna solamente per la lasciare, per ché lei l'ha lasciato primo. 
C'è tre attori nella poesia. L'io, che é un uomo, lei (la donna) e un'altra persona che parla due volte con l'io. Nel primo dialogo, l'io domanda lei come sta. Nel secondo dialogo, l'altra persona parla con l'io di lei. Nel scorso dialogo, l'altra persona domanda l'io come sta.

Il discorso diretto provoca l'effetto di realtà, di che le cose sono sucessi.

La poesia gioca sul doppio significato del verbo "andare". Nella prima ocorrenza, andare ha l'idea di movimento. Nella seconda volta, ha il significato di stare; é una domanda che significa "come sta?". Nella terza volta, la domanda significa "che cosa é sucessa?". Nella quarta volta, primo ha anche il significato di cose che succese, pero, doppo di legere il prossimo verso, ha il significato di movimento. Nelle quinta e sesta volte, ha il significato di stare, come nella seconda volta.

Gli altri stratagemmi, come le rime, le assonanzie e le allitterazioni danno il ritmo alla poesia, creano il effetto di musicalità.

Un altro gioco è quello dei due piano temporali dei presentee del passato. La poesia è scrita nel passato, con alcune volte, nel presente.

Colui che parla, l'io, non sembra essere una persona romantica, ma deve essere bello.

Il tono della poesia mi sembra comico, divertente.

Nella poesia, si parla che lei ha partorito e lui ha partito, doppo sono sposati. Lei ha lasciato lui. Doppo hanno sposato ancora ed in questa volta, lui ha lasciato lei.

\section{(D3)}

Il racconto "Occhi di Paola" narra una coppia sul letto e ci mostra un uomo svegliato che non riesce a dormire e mentre sua moglie dorme, lui trova il motivo, che è il ricordo di quando ha tradito Paola con la moglie di un caro amico suo vent'anni prima.

Il tema del racconto è il tradimento, il senso di culpa che non lascia Duccio dormire. Ci sono, nel testo, alcune coppie di elementi contrapposti semanticamente in cui il tema del testo e il senso di ciò che è narrato può essere basato come: la tranquillità e il tormento, l'innocenza e la colpa, la punizione e la impunità, il pecato e il pentimento, l'azzuro e il grigio.

Ci sono due personaggi diretti nel racconto: Duccio e Paola. Non sapiamo molte cose di loro, solamente che sono sposati da più di vent'anni e Duccio ha tradito Paola con la moglie di un caro amico suo. Sapiamo anche che sono sul letto. Di paola abbiamo la descrizione fisica. Sappiamo che lei ha una massa di capelli scuri, che sono tinti, ha la guancia piena e morbida e che ha anche i occhi grandi e azzurri, apena ingrigiti dagli anni. Di Duccio non abbiamo qualsiasi descrizione. Ci sono due personaggi indiretti: Giorgio e Franca. Sono apena citati nel racconto e sapiamo solamente che anche loro sono sposati e che Franca ha tradito Giorgio con Duccio. C'è il narratore, che può essere pensato come onnisciente, ma in casi specifici, come quando il narratore riesce a vedere che gli occhi di Paola sono aperti nel buio e un po' più ingrigiti, ma invece non sapiamo se lui sa veramente che cosa Duccio ha pensato o se Duccio informa il suo pensiero direttamente. Si può pensare in questo dubbio perché non ci sono le virgolete. Così possiamo pensare che l'enunciatore vuole confondere la voce del narratore e del personaggio e ha l'intenzione di creare questo dubbio.

E usato nel testo, come tempo verbale principale, il presente che causa la concomitanza tra il momento in cui si parla con il momento di cui si parla, tra il momento dell'enunciazione e il momento dell'avvenimento. Quest'uso crea l'effetto di avicinamento, di realtà. E oltre dell'uso del presente, l'enunciatore usa per construire l'effetto di verità alcune strategie come la descrizione fisica di Paola, il discorso diretto e l'uso degli antroponimi.

$\mathrm{Ci}$ sono altre due tempi verbali nel testo: il passato prossimo e il passato remoto. Il passato remoto è meno frequente e è usato da raccontare le cose che sono successe quando Duccio ha tradito Paola, vent'anni fa. Così, allontana il fato del tradimento e crea l'effetto di non essere rilevante al presente e che deve essere dimenticato, mentre il passato prossimo è usato da raccontare le cose che sono rilevante al presente come o fato di cui non l'ha più tradito.

C'è anche un unico caso di uso del presente gnomico o onnitemporale. Ocorre nel pensiero di Duccio: "Dunque, è così che vanno le cose, pensò, al risveglio: nessun rimorso, nulla cambia. Si può tradire e farla franca, anche con se stessi. Si può tranquillamente convivere con i propri peccati.". Quest'uso causa l'effetto di verità indiscutibile, di che non si pùo discordare di quel che è detto.

Il protagonista maschile è introdotto con l'uso del pronome direto atono: "Qualcosa lo tormenta", e questo stratagemma suscita la curiosità del lettore perché sapiamo che c'è un uomo nella storia, ma non sapiamo niente di lui ne come è.

Nella descrizione fisica di Paola c'è un'unione degli elementi positivi e negativi. Lei ha una massa di capelli (positivi), ma che sono scuri perché sono tinti (negativo), ha gli occhi azzurri (positivo), ma ingrigiti dagli anni (negativo). C'è l'oposizione principale tra l'elementi giovanili e l'elementi della vecchiaia. 
Verso la metà del primo paragrafo ci sono tre frasi che indicano il cambiamento nella narrazione: "E d'improvviso capisce. È per quel pomeriggio. Esatamente vent'anni prima”. Questi frasi cambiano la direzione del racconto e mostra al lettore che c'è un motivo per tutto ciò che è successo. E anche marca il cambiamento verbale del racconto, l'enunciatore comincia a usare il passato remoto.

Il verbo capire nella frase "E d'improvviso capisce" è duale. Ha un legamento semantico con il motivo per cui Duccio non riesce a dormire ("Non può dormire. Qualcosa lo tormenta. Ma non riesce a capire cosa"), ma ha un legamento sintattico al motivo per cui gli occhi di Paola sono ingrigiti (I suoi occhi grandi occhi sono nascosti dale palpebre, ma Duccio li immagina, azzurri, appena ingrigiti dagli anni. E d'improvviso capisce").

Ci sono due colori menzionati nel racconto (azzurri e grigio) che si riferiscono agli occhi di Paola. Possiamo fare alcune associazione di queste colori con il tema del racconto. L'azzurro può significare il disinteresse, la innocenza, il rispetto. Il grigio può significare la preocupazione, la colpa, il pecato. Questi sono alcuni elementi essenziale per la lettura del racconto.

L'opinione del testo è che non c'è imppunità. Possiamo dedurre dall'ultime frasi del racconto: "Nell'oscurità gli occhi di Paola sono aperti. Un po' meno azzuni, un po' più grigi”. Questo può significare che lei sa che Duccio l'ha tradito e sofre a causa di questo. Qualunque è punito, contuttoché non sia la persona che ha pecato. La punizione di Duccio è la sofferenza di sua moglie. Un giorno lui saprà che l'ha fatto soffrire e questa sarà la sua punizione, il pentimento che lui non ha mai sentito molti anni prima.

\section{(D4)}

La poesia di Patrizia Cavalli "L'io singolare proprio mio" parla di un amore che non può esistere o che non funziona perché l'enunciatore usa un periodo ipotetico della possibilità, per dimostrare che la situazione potrebbe essere migliore.

Osservando atentamente il primo verso, possiamo trovare molti elementi interessanti: c'è l'uso del pronome "tu"; se esiste un tu che ascolta, esiste anche un io che parla. Quest'uso esplicita la persona, che é rafforzata dall'uso del pronome possessivo "mia". C'è un riferimento alla porta che ci indica lo spazio; l'io è dentro la casa e il tu ne è fuori. C'è anche un riferimento al tempo con l'uso dell'avverbio "ora".

La poesia è divisa in 2 parte: la prima, che è la protasi del periodo ipotetico, comincia con "se ora tu..." e finisce con "ma che è successo?" e la seconda, che è la apodosi, comincia con "sarebbe" e finisce con "di successo".

I due avverbi di tempo ("ora" e "poi") possono indicare una successione temporale degli avvenimenti (ORA bussa e POI entra); l'uso di “ora" presentifica il testo avvicinando il lettore al tempo dell'enunciazione e l'uso di "poi" sposta l'enunciato ad un momento successivo. Non ci sono coordinate fisse nel tempo e questo fatto corrisponde alla funzione deittica.

Non si sa chi è l'io o il tu, non si riesce a sapere come sono, se chi parla è un uomo o una donna, sembra però che tra loro c'è un rapporto affettivo e l'io dipende dal tu, già che tutte le azioni sono praticate dal tu. Analizzando la poesia, è possibile interpretare che tra l'io e il tu c'è un rapporto omossessuale, e possiamo pensarci perché c'è una forte relazione di uguaglianza tra i personaggi che viene esplicitata nel terzo e nel quinto verso.

Ci sono molti riferimenti allo spazio e possiamo dividerlo in due: lo spazio della casa e lo spazio del corpo. Lo spazio della casa viene esplicitato attraverso la porta e ci indica dove è l'io. Lo spazio del corpo viene esplicitato attraverso la bocca ed oltre al rapporto tra i personaggi ("e poi tu entrassi dentro la mia bocca"), mostra una relazione con la porta della casa: attraverso la porta, si riesce a entrare dentro la casa ed attraverso la bocca si riesce a entrare dentro il corpo, che è lo spazio più intimo.

La presenza del discorso diretto è un riferimento al teatro e corrisponde ad un discorso immaginato e crea l'effetto di concreteza, fa credere che l'ipotesi è realmente possibile. Le parole tra virgolette possono significare che qualcosa non funziona bene, che c'è qualcosa di sbagliato e se fossero dette, potrebbero rappresentare una forte sorpresa del tu, provocata da qualunque motivo. Il discorso diretto si ricollega alla parte finale del testo perché sarebbe un pezzo di teatro di successo se il tu chiedesse cos'era successo.

Ci sono varie figure di linguaggio come per esempio le rime (occhiali, uguali, disuguali), la rima equivoca tra i due usi della parola "successo", l'allitterazione della "s", che crea l'effetto di sussurro, l'assonanza tra pezzo / successo. Queste figure creano il ritmo della poesia.

\section{(D5)}

Il testo di Romagnoli mette in evidenza la simbiosi tra mafia e politica, dimostra come una interviene nell'altra e attraverso quali strategie riescono a convivere insieme. Oltre a questo punto, dimostra anche la vita di un onorevole, un uomo importante della politica antimafia (lui è vicepresidente della comissione antimafia), che fa parte allo stesso tempo della mafia e cerca di prenderle in giro per ottenere vantaggi delle due parti. 
Il tema principale del racconto è appunto il rapporto tra mafia e politica, e possiamo rafforzare questa idea attraverso le scelte lessicali fatta dall'enunciatore. Come esempi del lessico della mafia ci sono parole come comissione antimafia (che è anche una scelta lessicale del tema politica), Palermo, Cosa Nostra, cosche, capofamiglia, famiglia ed ecc. Come esempi delle parole che appartengono al tema della politica ci sono voti, preferenze, onorevole, kennediano, rielezione, vicepresidente, ed ecc.

Oltre a questi temi principali, ci sono altri, come il doppio (rappresentado nel testo dalle parole ubiquità ed i verbi riflessivi come vedersi, ascoltarsi ed ecc.) e il tema del mass-media (rappresentato dalle parole trasmette, TV, radio, giornalisti ed.ecc.)

La scelta lessicale rende al testo la caratteristica figurativa, cioè, usa termini concreti, le figure, attraverso l'uso dei personaggi e gli esempi per raccontare un fatto reale. Questo modo di scrivere lascia più leggero il testo, senza $\mathrm{i}$ concetti che tutti conoscono, ma dimostra e racconta fatti che potrebbero essere successi veramente attraverso la narrativa ed i personaggi.

Dal punto di vista dell'attorilizzazzione, possiamo osservare che il personaggio principale, l'onorevole, viene introdotto in una prima volta attraverso un verbo in terza persona (risponde) e poi, attraverso l'uso del pronome "lui" nella terza riga e poi appare la parola che lo descrive "onorevole". Questo personaggio non ha un antroponimo, cioè, non ha un nome e non è raffigurativizato. La storia è raccontata da un narratore in terza persona e la sua voce si mescola e si confonde con il pensiero del personaggio principale. È un narratore extradiegetico, cioè, non fa parte della storia ed è un narratore osservatore, perchè non sa tutto quello che succede. I personaggi secondari appaiono nel racconto attraverso il discorso diretto, ecceto il sicario che è più un strumento che un personaggio. Il capofamiglia, che è rappresentato dalla voce della mafia, che ordina all'onorevole di fare tutto quello che vogliono per riescere a ottenere le preferenze e D'Ottavio, il politico che non appare nel racconto, ma ha un antroponimo, oltre ai giornalisti che fanno le domande all'onorevole. E c'è anche l'enunciatore che decide tutto, da la velocità al testo, sembra essere sempre in fretta e ci permette di pensare alle lacune.

Rispetto al tempo, possiamo individualizare il presente, che è il tempo più usato nel racconto, e crea l'ilusione che le scene vengono raccontate nello stesso tempo in cui accadono, l'effetto di concomitanza e l'effetto di attualizzare la storia. Questo è anche un segnale che rafforza l'idea che il narratore non è onnisciente. C'è anche l'uso de futuro, con l'effetto della promessa, o una verità assoluta, molto usato nei discorsi politici. C'è l'uso del passato prossimo che rappresenta un'apertura verso il passato, creando l'effetto del flash back. E c'è anche l'uso del congiuntivo imperfetto (offrissero), che crea l'effetto della possibilità di una scapatoia all'onorevole e alle persone come lui.

\section{(D6)}

Questa poesia rappresenta la poesia del quotidiano, ci mostra dove si trova la poesia nei nostri tempi, ci fa percepire appunto la commercializzazione della poesia e del poeta.

La poesia può essere divisa in tre gruppi: il primo va dal primo verso fino al sesto verso. Questa divisione mostra l'universo della critica letteraria. Dentro questo gruppo si può essere suddiviso nei versi cinque e sei, dove appare "l'io"; il secondo gruppo è composto dai versi sette, otto, dodici, tredici, quattordici, quindici e sedici. Questo gruppo mostra l'universo della poesia quotidiana, mostra dove si trova la poesia oggi, la società di consumo, in cui la poesia è una merce come qualsiasi altra; il terzo gruppo è composto dai versi nove, dieci e undici e ci mostra l'universo della poesia classica, con il "poeta" e le sue muse ispiratrici.

Possiamo dedure che questo terzo gruppo parla di una cosa lontana attraverso i verbi coniugati al passato remoto e perché parla dell'Ideale lontano, e dei milioni di poeti che morirono o delirando vissero a causa di quell'Ideale. Un altro aspetto per cui possiamo pensare alla poesia classica è l'inversione sintattica - "delirando vissero" - come nella grammatica latina, in cui il verbo è messo alla fine della proposizione.

In questa poesia ci sono molti riferimenti allo spazio, come ovunque, questo paese, "tavole rotonde", nella prima strofa, che ci fa pensare a un effetto tipo "zoom", in cui passa da una cosa molto generale a un'altra molto especifica. Un altro spazio interessante è il cuore, che sta nel verso dieci, e che sta nella parte in cui si parla della poesia classica. Questa è un'opposizione agli altri spazi che appaiono nella poesia. Il cuore è l'unico spazio in cui non c'è l'idea di commercializzazione. E poi ci sono gli spazi in cui la poesia può essere trovata, come "grandi magazzini", "settimanali illustrati", "pubblicità al cinema", "saponeta", "vinello toscano", "birra", "profumo" e "supermercato". Questi sono gli spazi in cui si fa la commercializzazione della poesia contemporanea.

L'ultimo verso (“- La gente guarda e tace, entra al supermercato”) può essere interpretato come un discorso diretto perché sembra che sia staccato della poesia, come se fosse una voce sola che dice come le persone reagiscono davanti la poesia. Questa voce può essere colegata all'io che appare nella seconda strofa, come se lui facesse una critica dicendo che la poesia sta in tutti i luoghi, ma la gente preferisce tacere e fare le cose utili.

Le virgolette usate per le "tavole rotonde" è anche un segno di critica o di ironia, cioè, lui fa un riferimento alle tavole rotonde, i luoghi in cui si devono discutere le cose e le mette tra virgolette per far capire che non è proprio 
questo che succede. Le tavole rotonde, i critici letterari non hanno più una funzione letteraria, anche loro hanno una funzione commerciale, hanno la funzione di dare e prendere premi, ma non discutono veramente la letteratura.

Questa è una figura abbastanza importante per l'interpretazione della poesia, ma la più importante, secondo me, è proprio quella dell'ultimo verso. L'immagine della gente, che guarda la poesia, non la riconosce o non la capisce, tace e entra al supermercato per fare le cose utili, oppure per consumare la poesia commercializata. Mostra l'alienazione delle persone e pure la commercializzazione della poesia e del mondo, in una maniera generale.

\section{ALUNO E}

\section{(E1)}

Questo é uno studio dello testo secondo diversi elementi. Il racconto ha due elementi contrapposti che sono la memoria d'elefante e il colabrodo, che non prende memoria nessuna. La grande preocupazione dello personaggio Luca è il desidero di essere come la prima, quando aveva molto buona memoria. L'uso di questi expressione sono metafora e antitese e provoca effetto de tristeza e enfasi del' elementi.

Il testo presenta qualcune qualite dello personaggio: suo nome, sua ità e mai di più la sua ossezione nella idea de recordarsi o muorere.

Il racconto ha una spezie di marcatura di tempo che finisca com la morte dello personaggio stesso con la ricordazione che lui vuoleva.

\section{(E2)}

La prima impressione che ho di questa poesia è l'immagine di un uomo che visita una donna nell'ospedale, dopo lei aver partorito, però la poesia parla della separazione matrimoniale tra marito e moglie che non hanno vivito bene, stesso con un figlio in comune. Ormai il tema principale è l'amore tra due persone ed il rapporto non corrisposto. Il tema è anche l'indifferenza con l'amore e con le cose della vita.

Mi sembra che c'è tre attori nel testo: l'uomo che fa la visita e che anche è il narratore, la donna che ha partorito e che ha lasciato l'uomo. La terza persona è una che parla con l'uomo nell'ospedale.

L'effetto dell'uso del discorso diretto nella poesia è di illusione della realtà, della presenza dei personaggi.

C'è due volte l'uso del verbo andare: una con il significato di andare stesso, dove il narratore parla di aver andato all'ospedale. Nella seconda volta, il significato è di situazione di vita, quando una persona domanda al narratore: come è andata? Nella terza volta, il narratore rispose: "È andata via" ed il significato è di "partita".

Nella maggiore parte è usato il tempo passato, però c'è un gioco con il presente, come in: "Come è andata?" dove si usa la sonorità che sembra con il tempo passato.

L'effetto dell'uso della rima, dell'assonanza e dell'allitterazione è sonoro, come sempre succede nelle poesie. Però qui questo effetto è creativo e interessante, con la rima con le dialoghe, per esempio: "L'ho sposata", "come è andata?". L'allitterazione con la lettera "t": partorito, pentito, andata, sposata, ricorda la parola del tema principale: la partita e l'uso del passato.

Il tono della poesia è serio e divertente: serio perché parla del rapporto tra esseri umani e divertente per la forma come è detto, con persone che non si fermano con altre, che forse non si sforzano per avere un buono rapporto.

Succede nella poesia che un uomo ha visitato sua antica moglie nell'ospedale, dopo lei aver partorito il loro figlio. Lì sa che lei ha sposato un altro. Quando una persona le domanda come è la sua vita, lui dice che ha sposato una seconda moglie, però anche ha lasciato questa donna ed è solo adesso.

\section{(E3)}

Questo è più un racconto da Romagnolli, di quegli che finiscono sempre com una grande sorpresa nell'ultima riga. Qui è descritta la notte di sono di un'uomo, Duccio, che nonostante avere la fama di dormire a comando, non può dormire, perché in quell'occazione ha una grande angoscia, una colpa, da ricordare di avere tradito sua moglie Paola, com la moglie del suo grande amico. È allora un doppio peccato che pesa sulla sua coscienza.

Lui, nella sua isonnia e nella semioscurità della stanza guarda la sembianza della moglie, la sua aparenza, i suoi capelli, piutosto neri, oggi tinti (la coppia à sposata più vent'anni fa), quella guancia diversa di prima, e quegli occhi nascosti dalle palpebre, ma che lui conosce bene: sono di un azurro intenso, e sembra que dimostrano molto aldilà della personalità e della principale caratteristica di Paola, la chiave e l'elemento principale del racconto.

Con suo rigiro nel letto e sua inquietudine, Duccio finisce per svegliare la moglie accanto, che domandagli che cosa succede. Lui si scusa allegando avere avuto un incubo in cui la tradiva. Lei si è contenta con l'uso del termine "incubo". Lui allora si è più tranquillo, perché si sente perdonato. Lui dorme. Però nel buio Paola apre gli occhi che 
di azurri diventano grigi, lasciando un dubbio su che cosa pensa, se ha davvero perdonato il marito, o se ha forse fatto nel passato anche qualsiase cosa uguale quella che lui ha fatto: un tradimento.

Il tema del racconto è molto chiaro: Il tradimento, il senso di colpa e la sfiducia matrimoniale. Questo tema è trattato di maniera seria, per riferirse a una cosa successa vent'anni fa, e una volta soltanto, ma che dà fastidio alla coscienza del marito ancora, nonostante lui avere diverse scuse per si stesso: "nessun rimorso, nulla cambia".

Però l'idea che rivela il tema appare soltanto nel mezzo del racconto. Prima è dimostrato il tormento del marito e l'immagine di quegli occhi di Paola, azzurri rappresentando forse la belleza, la bontà, la comprensione della moglie, in opposizione alla fine del racconto, in cui c'è un grande misterio con il cambiamento del colore degli occhi per grigio, rappresentanto il contrario, cioè, un'immagine cattiva.

Sono tre le persone che parlano nel racconto: Il narratore onnisciente, il marito Duccio e la moglie Paola. È interessante osservare che ognuno usa un tempo verbale, per esprimire la situazione, d'accordo con il momento dell'enunciazione. Per esempio: Il narratore usa il presente, nel inizio del racconto, descrivendo lo stato di Duccio in quel momento, che non riesce nè dormire nè sapere che cosa succede. Quando si ricorda del tradimento que ha fatto, è usata la voce di Duccio con il passato remoto, rappresentando um momento enunciativo, un passato, rispetto quel momento della storia. Dopo é usato il passato prossimo quando si rappresenta il presente della storia, ma un passato rispeto al lettore. La voce della donna é in presente, traverso l'uso del discorso diretto, nel dialogo con il marito, cosa che crea un effetto di realtà. Questo é anche um presente nella storia e un passato rispetto al lettore. Il racconto finisca con il presente nella voce del narratore, lasciando aperta la conclusione della storia e la discussione su questo assunto.

\section{(E4)}

Questa poesia, il cui tema può essere la disillusione amorosa, ci fa venire in mente diverse cose: La solitudine di una persona con la mancanza dell'amore lontano ed il desiderio del suo ritorno, la diversità di pensieri tra gli amanti e la bugia della vita rappresentata nello spettacolo che può essere il rapporto tra la coppia, una volta che fa riferimento al teatro.

Ci sono diversi elementi che danno un'idea un po' definita per capire la situazione, oltre a quel senso astratto e figurativo della poesia, come per esempio la congiunzione "se" che inizia la poesia, e che crea una condizione di ipotesi e di attesa, un tempo determinato dagli avverbi "ora" e "poi", un "io" e un "tu" determinati rispettivamente dai pronomi "miei", "mia" e "mi", e dalla desinenza dei verbi e il pronome esplicitamente citato. C'è anche uno spazio fisico con l'espressione "bussassi alla mia porta" e uno astratto con "entrassi dentro la mia bocca". L'altra osservazione importante é che l'avverbio "ora" presentifica il testo, in una contemporaneità con il lettore, mentre il "poi" rappresenta un momento successivo rispetto al momento dell'enunciazione, e questa successione viene rafforzata dalla congiunzione "e".

La poesia è divisa in due parti: La protasi, che corrisponde al periodo ipotetico introdotto dalla congiunzione "se", in cui i verbi vengono coniugati al congiuntivo passato, e la seconda, l'apodosi che è la conseguenza dell'ipotesi, con in verbi al condizionale.

Il discorso diretto nella poesia ha la funzione di creare una voce dando un po' di vita al testo e di cambiare l'aspettativa, con il rompimento della successione che c'era e coglie l'occasione dell'idea del riferimento al teatro, per creare una frase dialogata. La frase "Amore mio, ma che cosa è successo" che sembra un sollievo all'enunciatore, rappresenta un discorso immaginario, crea quell'effetto di realtà, e si ricollega alla parte finale del testo rafforzando anche l'idea di scena teatrale citata. La parola "successo" viene usata due volte con significati diversi: uno di "cosa accaduta" ed altra di "un bellissimo spettacolo teatrale"

Gli elementi della persona e dello spazio non definiscono con chiarezza chi parla con chi, e questa è una caratteristica del genere poetico, ossia, creare un'immagine universale con diverse possibilità di interpretazione. Però possiamo dire che un amante, forse una donna, d'accordo con l'espressione "dentro la mia bocca", che può rappresentare l'organo sessuale femminile, parla al suo fidanzato. L'altra indicazione che l'enunciatore è una donna è la delicatezza con la quale sono scritti i versi. D'altro lato, l'ethos del testo, attraverso l'uso delle espressione che possono essere capiti come elementi erotici, mostra un enunciatore progressista, senza preconcetti rispetto alla sessualità, in maniera che il rapporto descritto nella poesia può essere anche tra due persone dello stesso sesso.

Infine l'uso delle immagini di diverse parti del corpo umano ha un senso particolare di rapporto amoroso e erotismo. Per esempio, "bussare" rimanda a mano e dita. "Occhiali" rappresenta gli occhi, la visione del mondo, il tipo di rapporto. "Bocca" è quella parte usata per bere, baciare, parlare, e con la possibilità di "entrare" come dice il verso, dimostra uno spazio corporale e intimo. La poesia è anche ricca al piano dell'espressione, per esempio, con la presenza del polisìndeto con la congiunzione "e", la rima, l'assonanza con le parole porta/bocca e pezzo/successo e le alliterazioni soprattutto con i fonemi sibilanti, che producono quel suono di sussurro, rafforzando l'idea di momento amoroso, in cui un amante parla in bassa voce, all'orechio dell'altro. 


\section{(E5)}

Questo è più un testo di Romagnoli, quello scrittore che lavora com temi polemiche e lascia di solito una grande sorpresa riservata per l'ultima riga del racconto.

Qui si fa il dibattito sulla questione del rapporto tra la mafia e la politica, ed è qualcosa così che ci fa venire in mente dopo averlo letto, ossia, l'incoerenza di un politico che fa finta di lottare contro la mafia, ma in verità si è beneficato da lei.

Il testo é scritto in maniera figurativa, ossia, usa personaggi e situazioni concretti, cioè, una scelta lessicale, per rappresentare i temi trattati, come per esempio: "commissione antimafia", "Cosa Nostra", "ciuffo kennediano", "cosche", "capofamiglia" si riferiscono al tema: rapporto tra la mafia e la politica; "onorevole", "kennediano" e "rielezione" si riferiscono al tema: politica; "doppia vita", "accordo" e "l'ubiquità" si refirscono al tema "doppio"; e al tema "massmedia" sono collegati i termine "TV", "intervista" e "giornalista". L'effetto dell'uso di termini concreti crea un effetto di realtà, di avicinamento dell'immagine al lettore, ed aiuta la percezione del messaggio, più del tema trattato in maniera astratta.

Dal punto di vista dell'attorializzazione, il testo è costruto in maniera speciale, usando un narratore che si mescola, che si confonde con il personaggio principale, l'onorevole, risultando in una voce che alle volte ci fa domandare: chi parla adesso? I personaggi secondari sono: il giornalista, il capofamiglia, il sicario ed anche la TV, che hanno la funzione della rivelazione del vero carattere dell'onorevole, attraverso il rapporto tra loro.

L'altro aspetto interessante del racconto è l'uso dell'infinito per iniziare la narrazione, che è in terza persona e non ha un soggetto. L'uso della catafora, che permette soltanto nello sviluppo del testo sapersi che c'è un "lui" del quale si parla, è anche un ricorso per creare un clima di suspense e un sentimento di curiosità nell lettore.

Rispetto alla temporalizzazione, il presente è il tempo principale, e il suo uso crea l'illusione che la scena sia raccontata concomitantemente al tempo che avviene. Il verbo "fare" compare nel testo coniugato al futuro per ricordare un discorso politico, in cui si ascolta molto i termine "promettere" e "fare".

La questione dello spazio è molto importante per lo sviluppo dell'idea centrale del racconto, ossia, le cose doppie. Ci sono due spazi principali: la TV e la stanza di un albergo. Così c'è un uomo fisicamente vero nella stanza che osserva la sua immagine in TV, e che in media rappresenta nemico della mafia ma occultamente è il suo amico. C'è un uomo colletivo e l'altro particolare. Uno che sembra sincero ai mafiosi e un'altro falso, che li usa solamente per il sostegno della sua ambizione personale.

Infine dopo lo sparo del sicario c'è un'ultima situazione doppia: la vita o la morte dell'Onorevole.

\section{(E6)}

Questo è un poema scritto da Sebastiano Vassali che ha come tema principale la questione del consumismo attuale, che cambia tutte le cose, anche le manifestazioni artistiche, trasformandole in beni di consumo. Così il poeta prova di spiegare o di capire cosa è diventata la poesia oggi. È interessante osservare che nonostante il poema abbia stato scritto nel 1972 ed usi l'avverbio deittico, rimane attuale, perché questa è una funzione della poesia. Nella pazza volontà di dire cos'è la poesia, il poeta non riesce farlo e finisce soltanto dicendo dove lei si trova. La cosa che questa poesia ci fa venire in mente alla prima vista è che il poeta cerca di mettere delle idee attuale nei suoi versi, ma non le trova, e che lui prova di trasformare le cose non poetiche in poetiche, ma finisce parlando soltanto del consumismo, un'idea forte nei nostri giorni, che impregna tutto e sembra dominare anche l'arte.

Nei suoi aspetti formali, la poesia mostra anche quello che già sappiamo rispetto alla poesia moderna: che non ha più il bisogno della rima o della metrica, ma il messaggio è più importante, e il messaggio è usato dal poeta come che uno sfogo, lui prova di chiamar l'attenzione del lettore rispetto a che punto siamo arrivati.

Ci sono diverse parole, come "tavole rotonde", "grandi magazzini", "pubblicità", "facce della gente", "saponetta", "supermercato", tutti i termini che di solito non dovrebbero andare in un universo poetico ma che nel nostro caso definono il tema generale della poesia, che è l'uso comerciale dell'arte.

Rispetto al tempo, la poesia usa principalmente il presente, anche perché si riferisce al momento "oggi”. Ma c'è anche l'uso del passato remoto che aiuta a dividere la poesia in diverse parti, con una passeggiata al mondo antico, quando c'era la figura della musa per ispirazione del poeta, al mondo cortegiano dove la poesia sembrava più pura $\mathrm{e}$ bella, o quando il poeta aveva un "Ideale" vero.

In verità il poeta del'La poesia oggi non vuole dire che non esista più la poesia, anche perché sappiamo che la poesia non ha lasciato di esistire mai, perché è una espressione dell' "io" e che ci sono un'infinita quantità di poeti e di opere, così come sono diverse le maniere di diffusione della poesia, ma invece, lui vuole criticare le cose che finiscono per corrompere il puro spirito poetico, come il massmedia ed il consumismo, con la cattiva idea che si è messa oggi in teste nostre, di volere tutte le cose pronte, di non rifletere più sulla vita. 
L'uso dello spazio in questa poesia anche serve a criticare la maniera come è trattata la poesia. Per esempio, quando dice: "ovunque, anche in questo paese" ossia, in Italia, la culla della poesia moderna, cosa c'è oggi? C'è la tavola "rotonda" che rotola e arriva alla stessa conclusione, ossia, forse a conclusione nessuna, ed i premi che possono rappresentare la creazione poetica senz'uso del talento vero. C'è la società di consumo dove ha l'assenza della poesia, la corte antica dove forse si troverebbe una poesia più sincera, e alla fine c'è il supermercato, il rifugio attuale della poesia.

Oltre al senso negativo che questa poesia esprime, si può pensare in un altro, positivo, che sarebbe quello di vedere delle immagine poetiche in tutte le cose? Sì, sarebbe un sollievo per noi, lettori di poesie, che in nostro mondo confuso e stanco si potrebbero trovare la poesia in una saponetta, in un vinello toscano o in "un amore lontano su birra o su profumo". Però l'ultima frase della poesia sembra che vuole smenticare questa idea, perchè oltre a usare un trattino per introdurre un discorso diretto, ossia, una voce che rompe il sistema che si era seguito, rappresenta qualcuno che osserva gli avvenimenti e ci sveglia per la realtà attuale: che forse tutti noi siamo come automi, che soltanto guardiamo la vita, ed insensibili non pensiamo più, invece, taciamo soltanto preoccupati com la stessa sopravvivenza.

\section{ALUNO F}

\section{(F1)}

Il texto "Luca non dimentica", di Gabriele Romagnoli, è basato in due elementi contraposti, che sono: "ricordare" e "dimenticare".

Luca è un uomo che aveva una buona memoria, però adesso "è un colabrodo", e ha appena trent'anni.

Lui voglia di ricordare il nomi di un giocatore di pallone, ma ha molta difficoltà. Allora, lui fa un patto com il destino: si lui non ricordare il nomi prima di le sei, lui moriró. Lui ricorda il nomi, ma già è tardi. Allora, un'auto lo travolge.

Luca abita a Milano, una città moderna, in che predomina la velocità, e codesto sorge in testo per l'attitudine di Luca, che concedere a lui un tempo per vivere o morire.

\section{(F2)}

La poesia mi sembra un po' strana, a principio sembra triste, poi parla sul amore finito. Ma al fino il gioco con le parole, la rima fa apparire l'effetto di umore, come in: “... Ma ho lasciato anche lei/parto alle sei”.

Mi sembra che il tema principale può essere l'amore finito, o il matrimonio finito, oppure sul momento di lasciare una persona;

In questa poesia può avere tre persone: due uomi e una moglie. Uno di questi uomi può essere il marito della moglie che ha partorito; l'altro uomo può essere un amico del marito.

L'enunciatore, quando decide di introdurre il discorso diretto, crea un effetto di realtà, come se questo può succedere veramente, nella vita reale. Crea anche, un effetto di prossimità con il lettore, che così, può capisce meglio sul che cosa si dice nella poesia.

In questa poesia hanno vari occorrenze del verbo "andare", che hanno vari significati:

1. "sono andato" $\rightarrow$ verbo "andare" al passato prossimo, ri riferisce a lui, probabilmente il marito della moglie che ha partorito.

2. "come va" $\rightarrow$ questione sulla vita ("come va la vita?"), probabilmente l'amico del marito chiedere a lui come va la sua vita.

3. "Come è andata?" verbo "andare" al presente; questione che l'amico del marito fa a lui, poi voglia sapere come va la moglie che ha partorito.

4. "È andata via" $\rightarrow$ risposta che l'uomo dà a chiesta. Probabilmente la moglie ha partorito, lasciato il marito.

5. "Come va?" $\rightarrow$ chiesta (come va la vita); probabilmente l'amico voglia di sapere come il suo amico sta, dopo la partita della moglie.

6. "Va" $\rightarrow$ risposta a chiesta, che può dire: "mezzo a mezzo" oppure "non c'è male". L'uomo risponde a chiesta del suo amico.

In questa poesia hanno due tempi verbali, e questi sono misti. Il tempo passato parla del nascimento di un bambino o bambina, e di quando l'uomo è stato con la sua moglie. Il tempo presente parla della partita della moglie, che ha lasciato suo marito. Adesso, anche lui va partire.

È interessante osservare l'effetto della rima, della assonanza e alliterazione. La rima propizia un ritmo nella poesia e nella ultima strofa crea un effetto di umore. L'assonanza del "i" crea una sensazione di dolore, che può stare in legamento con il parto. L'assonanza del "a", crea un effetto di stanchezza, come l'uomo è stanco, triste per il fine del 
matrimonio. L'allitterazione del "s" nel inizio della poesia crea la sensazione di silenzio, come se lui sono stato nel ospedale.

Io penso che l'uomo, marito della moglie, è un uomo di poca età, più o meno venticinque anni, c'è capelli neri, occhi castani, senza barba o baffi e altezza media. Già l'uomo che fa le chieste è un po' più vecchio che l'altro, è alto, ha capelli brizzolati, occhi castani e ha barba e baffi. E per finire, io penso che l'uomo (l'amico del marito), consiglia il suo amico a dialogare con la moglie, perché adesso loro hanno un figlio. Allora, l'uomo e la moglie ricostruirono la loro vita e vivono insieme con il loro figlio.

(F3)

A partire da lettura de titolo, il lettore può immaginare qualche cosa rispetto al tema del racconto. Forse il racconto può trattare di qualche cosa nascosta, che non si può vedere completamente (nascosta dagli occhi).

In generale, gli occhi hanno legamento con l'idea di verità, di evidenza, trasparenza. Quando si fa qualche cosa che non se vuole che nessuno scopra, le persone non si vedono dirittamente, non si vedono negli occhi, perché hanno paura che le altre persone sospettano o scoprano la punta di qualche segreto.

Cosi, nel racconto il narratore varie volte si rimete agli occhi di Paola, perché questo danno ai lettori qualche idee del sentimento o dello stato di spirito del personaggio.

Dopo la lettura, si sa che il tema principale del racconto è il tradimento, dopo la colpa, il pentimento, ecc..., cose che hanno legamento con l'idea scritta all'inizio di questo testo, rispetto al titolo del racconto.

Il racconto è narrato in terza persona, com un narratore onisciente, che si uttilizza principalmente del tempo presente. Questo crea nel lettore la sensazione di che il narratore è un osservatore di tutto quello che succede, e il tempo presente crea l'illusione di simultaneità, come se il narratore raccontasse in presenza.

Il racconto si passa dentro dalla stanza di una coppia - Duccio e Paola - dove il marito si è tormentato dalla colpa di aver tradito sua moglie vent' anni prima, com la moglie di un suo amico.

Senza essere riuscito a dormire, lui guarda Paola dormendo, e la discrive di un modo positivo (euforico), parla dalla massa dei suoi capelli, che ora sono tinti, del profilo della sua guancia, "ancora piena e morbida", e questo crea nel lettore l'immagine di una donna ancora bella, (probabilmente loro non sono giovani), che si preoccupa con la sua apparenza, che ha accuratezza con i capelli, ecc.

Lui pensa nei suoi occhi "nascosti dalle palpebre" (così come il segreto del tradimento, che ancora è nascosto) e "li immagina azzurri, appena ingrigiti dagli anni”.

A partire di questo pensiero di Duccio, rispetto agli occhi ingrigiti di Paola, comincia tutta una riflessione di lui sul tradimento che ha fatto. Per lui, il grigio negli occhi di Paola è dovuto a "quel pomeriggio" vent'anni prima - il pomeriggio del tradimento.

Il grigio può creare nel lettore la sensazione di dubbio, della tristezza, di qualche cosa indefinita, che non si sa con certezza. Forse si può pensare che è così che Paola si sente, perché probabilmente, lei ha qualche dubbio sul comportamento di Duccio, ma non è riuscita, oppure non vuole scoprire la verità. Ma quell'ombra del probabile avvenimento le lascia così, con gli occhi ingrigiti e non più azzurri, come prima.

L'azzurro può essere associato alle cose positive, all'idea di tranquillità, di pace (perché c'è anche legamento con il cielo, con il mare), e Paola non si è stata così, al contrario, vive nell'ombra del dubbio, dell'incertezza e probabile infelicità, perché forse, in fondo lei sa del tradimento di Duccio.

Gli occhi di Paola sono come l'immagine di sua anima, rifletono quello che va al suo cuore, è come se lei vivesse una tempesta addentro, e fuori dovuto alle convenzione della società, se vedesse nell'obbligazione di mantenere l'apparenza di serenità, come se nella sua vita con Duccio non avesse nessuna macchia, nessuna interrogazione. Perché fare la moglie tradita non è facile e nessuna donna vuole assumere questo ruolo.

Già Duccio, tormentato dalla colpa, riccorda il pomeriggio del tradimento e le cose che fece dopo arrivare a casa sua. Vent' anni dopo, il ricordo del suo comportamento normale lo sorprende. È interessante osservare che in questo brano (ancora nel primo paragrafo), l'autore uttilizza il passato remoto per parlare delle cose che Duccio ha fatto: "tornò a casa"; "si fece la doccia"; "mangiò con lei", uno stratagemma che fa allontanare questi avvenimenti del presente, come se il tradimento si avesse perso in qualche luogho di un passato davvero lontano, quasi spento, ma che qualche volta ritorna come un spetro, come adesso.

Al fine del primo paragrafo c'è una riflessione che forse, si possa considerare come una delle più importante del racconto: "Dunque è così che vanno le cose, pensò, al risveglio, nessun rimorso, nulla cambia. Si può tradire e farla franca, anche con se stessi. Si può tranquillamente convivere con i propri peccati”.

Qui, le parole del personaggio Duccio si mesclano alle parole dell'autore, in una mescolanza di soggeti (autore X personaggio), che crea nel lettore la sensazione di essere questa l'idea dell'autore, che si inserisce nel racconto attraverso questa strategia del discorso indiretto libero. 
Si può pensare che questo è anche il pensiero di Duccio, nella mattina, dopo il tradimento (si può pensare così dovuto all'espressione "al risveglio"). Dovuto questo, dopo aver tradito Paola (vent'anni prima), Duccio non si sente colpato; perché ha ritornato a casa sua e ha fatto le cose normalmente, come se niente aveva successo; per questo lui ha pensato: "Si può tranquillamente convivere con i propri peccati", perché in questo caso soltanto lui sa del tradimento, lui è il proprio giudice, e forse, in quel momento la sua coscienza sarebbe tranquilla, perché non aveva nessuno a condanarlo, a domandarlo.

Vent'anni dopo, le cose si sono cambiate, e oltre alla sua coscienza, ci sono gli occhi di Paola, adeso ingrigiti, che lo fa ricordare il tradimento e sentirsi colpato. Dunque, quella frase pensata vent'anni prima come una verità o un pensamento universale, valida per tutte le persone, adesso non si applica più a lui, Duccio, perché è tormentato, agitato e non può dormire dovuto a questo ricordo.

Il secondo paragrafo c'è inizio con il passato prossimo: "Non 1'ha più fatto. Aveva perfino dimenticato che fosse accaduto". Questo crea nel lettore l'effetto di avvicinanza degli avvenimenti al tempo presente (stabilisce una relazione tra il passato e il presente).

Se la frase "Non l'ha più fatto" è riferente al tradimento, come se Duccio non avesse più tradito Paola dopo quella volta, forse si può interpretare che l'autore vuole accentuare questo, che Duccio ha tradito Paola in quella volta, nel passato remoto. Adesso lui "non l'ha più fatto" - passato prossimo, che mostra come Duccio si è cambiato.

Nell'ultimo paragrafo del racconto, Paola si sveglia e vede Duccio "seduto sul letto". Lei gli domanda che cosa ha successo e lui risponde che ha avuto un incubo, in cui tradiva Paola con Franca, la moglie di suo amico Giorgio.

Qui il lettore conosce gli altri personaggi del racconto, e scopre il nome della donna con la quale Duccio ha tradito sua moglie. In questo momento Paola è molto affettuosa con lui e gli accarezza la mano, fino a che lui si dormenta.

Adesso è lei chi non può dormire, e l'ultima righa del racconto fa finire l'impressione di equilibrio e serenità, e lascia il lettore in dubbio: “Ora la stanza è buia. Nell'oscurità gli occhi di Paola sono aperti. Un po' meno azzurri, un po' più grigi."

Dopo la lettura di quest'ultima righa, il lettore può interpretare che Paola sapeva del tradimento, e che il comportamento di Duccio e suo incubo rafforzano questo pensiero di lei; per questo, adesso i suoi occhi sono un po' più grigi, pieno di malinconia e tristezza.

È interessante osservare che il buio della stanza c'è legamento e rafforza il grigio degli occhi, mentre l'azzurro si contraponne al buio e al grigio.

Dopo la lettura e analisi di questo racconto, si può pensare che gli opposizioni semantiche fondamentali, sulle quali il testo si basa sono: luce $\mathrm{X}$ ombra; coscienza tranquilla $\mathrm{X}$ rimorzo; assoluzione $\mathrm{X}$ punizione; innocenza $\mathrm{X}$ colpa; occhi azzurri X occhi grigi; luminosità X oscurità; tranquillità X pentimento. Queste coppie di elementi percorrono tutto il racconto e sono giustificato e allo stesso tempo giustificano gli altri elementi che appariscono lungo il racconto. Come esempio, si può parlare dell'opposizione tra assoluzione X punizione, sulla quale Duccio si tormenta tutto il tempo.

La punizione, in questo racconto, non si dà nella maniera concreta delle cose, non è Paola chi urla con lui e esige spiegazioni, ma è lui stesso che si sente in colpa, rimorso, pentimento, dovuto al tradimento. Forse si può pensare che questa colpa è l'opinione del testo riguardo al peccato e all'impunità.

Il testo e il modo come viene presentato, danno ai lettori la possibilità di un'interpretazione del tradimento come peccato. Questo si può dedurre attraverso il comportamento di Duccio, che si è tormentato, non riesce a dormire, ricorda il tradimento e ha un incubo sul questo; probabilmente se lui avesse la coscienza tranquilla, non si ricorderebbe più di questo, o non si tormenterebbe con questo.

Gli occhi grigi, che possono rappresentare l'ombra, il dubbio, la tristezza, ecc. Rafforzano quest'idea del tradimento come una specie di peccato, di una cosa che può essere punita attraverso la propria coscienza.

Pensando adesso alla costruzione del testo, si può dire che è un racconto con le frasi brevi, che creano un effetto di suspense nel lettore; lo spirito del testo è concitato, accelerato, e il discorso è concentrato.

Così, per finire, si può pensare alla definizione di Conrtázar sul racconto. Secondo lui, il racconto vince il lettore con un colpo di grazia, probabilmente dovuto al discorso più concentrato, e alle altre caratteristiche (sopra scritte), che fanno parte di questo genero narrativo.

\section{(F4)}

Un poema dà al lettore la possibilità di varie interpretazioni. L'obbiettivo di questo testo è analizzare le ipotesi interpretative di questa poesia a partire dalle varie voci che hanno partecipato alla discussione nella lezione.

Il poema di Patrizia Cavalli fa parte del libro Poesia, uscito nel 1992.

Dopo aver fatto una prima lettura del poema, mi sono venute in mente varie cose. La prima è che si tratta di un sogno del soggetto lirico, il desiderio di un avvenimento speciale e allo stesso tempo inaspettato per lui, forse sarebbe un amore impossibile, o il ritorno della persona amata che è andata via, ecc. 
Il poema comincia con un "Se", 1'unica parola scritta con la maiuscola nel poema e questo indica l'uso del periodo ipotetico della possibilità. Il periodo ipotetico in questo caso, può essere diviso in due parti: la prima è la protasi, che presenta una condizione, la seconda si chiama apodosi e costituisce una conseguenza.

Il primo verso "Se ora tu bussassi alla mia porta", presenta un avvenimento proiettato verso un'ipotesi futura. Questo è confermato dall'uso dell'avverbio temporale "ora" e dal congiuntivo imperfetto "bussassi".

Qui non appare esplicitamente 1'io, quello che parla e rappresenta il soggetto lirico del poema, però, il "tu" presuppone un "io", che così diviene implicito. La presenza di questo io sarà più concreta solo al terzo verso: "e io togliessi i miei che sono uguali". Così abbiamo i soggetti del poema, due persone, un "io" e un "tu", probabilmente, o secondo la mia interpretazione, una coppia.

Il poema è pieno di immagini che rimandano ai sensi umani come il tatto, il gusto, l'udito, e alle parti del corpo, che vengono suscitate attraverso i verbi e qualche sostantivo, come "bussare" e "togliere", per esempio, che rimandano alle mani; gli "occhiali" che rimandano agli occhi; la "bocca" che viene citata esplicitamente, ecc. Questo suggerisce al lettore l'idea di un amore carnale, vissuto prima di una possibile separazione.

É interessante analizzare anche l'immagine suscitata dagli occhiali, che secondo me è una metafora per maschere. É come se dopo di vedersi un'altra volta, in un incontro più intimo, i soggetti togliessero le loro maschere, usate nella vita sociale, ma che sono dispensabili in un rapporto amoroso sincero. Gli occhiali suggeriscono anche l'idea di una lente per vedere la vita, però quando siamo vicini ad un'altra persona, diventano dispensabili.

Altre immagini interessanti appaiono nel quarto e nel quinto verso: "e poi tu entrassi dentro la mia bocca / senza temere baci disuguali", che forse indicano la disugualianza di sentimento tra i due.

Alla fine abbiamo questi tre versi: "e mi dicessi: "Amore mio, / ma che è successo?", sarebbe un pezzo / di teatro di successo." Qui abbiamo altre tre immagini interessanti: il vocativo "Amore mio", che rafforza l'idea di intimità, già indicata prima, da "baci disuguali". Il "ma" indica 1'introduzione di una domanda e ricorda anche l'oralità del teatro, che ha legame con "pezzo di teatro di successo". Questo discorso diretto, oltre a creare l'effetto di realtà, dà più concretezza all'ipotesi creata dal soggetto lirico.

Il "pezzo di teatro di successo" può indicare anche la difficoltà di realizzazione di questo avvenimento. Che il "tu" bussi alla porta dell'io è forse impossibile, tanto che se questo succedesse "sarebbe un pezzo di teatro di successo".

La citazione del teatro può indicare anche 1'opposizione tra finzione e realtà; la prima propone la realizzazione dei sogni e volontà impossibili e la seconda, la realtà, ci mostra concretezza e tante volte delusione.

La ripetizione della parola "successo" alla fine della protasi e dell'apodosi rafforza l'idea di oralità e di improvviso del teatro, ma può rimandare anche ad un rapporto più intimo, che permmitte l'uso colloquiale della lingua.

Anche gli aspetti formali del poema sono interessanti: abbiamo l'uso predominante del congiuntivo imperfetto, che rafforza l'idea di ipotesi indicata dal "Se" all'inizio. L'uso della congiunzione coordinativa "e" e del pronome relativo "che", che creano la sensazione di aspettativa della prossima scena.

L' alliterazione "s" è più palese e ricorda un susuro. È come se il soggetto lirico declamasse il poema a bassa voce al "tu", e questo rafforza l'idea di un rapporto più intimo tra l'"io" e il "tu".

L'analisi dell'ethos del poema indica l'occorenze di idee con legame al corpo umano (bocca, mano, udito, ecc.), la brevità e il colloquialismo nel modo di esprimere le idee, che più di una volta rimanda all'idea di intimità tra 1'"io" e il "tu".

\section{(F5)}

Il racconto L'onorevole doppia chance di Gabriele Romagnoli (Navi in Botiglia, 1973) tratta dell'episodio finale della vita di un onorevole. Lui è nella stanza di un albergo di Palermo vedendosi in tv in un'intervista. Oltre ad essere un onorevole, lui è vicepresidente della commissione antimafia, però ha una doppia vita perché è anche coinvolto con la mafia.

C’è un sicario che l'osserva nell'albergo ed aspetta il movimento più opportuno per ucciderlo, mentre invece, l'onorevole guarda la sua immagine e si ammira in TV.

Alla fine del racconto, l'onorevole viene ucciso dal sicario mentre ironicamente la tv continua accesa con la sua intervista.

Una delle cose più palese ed interessante del racconto è la questione del doppio, che c'è inizio nel proprio titolo ed è presente in tutto il testo, dalla struttura alla vita dei personaggi.

Ci sono varie voci che si mescolano e si confondono, ed in una prima lettura non si capisce né chi parla né quando. Si può pensare che il racconto c'è inizio con la voce del sicario, è lui chi pensa: "Buffo. Buffo essere nella stanza di un albergo di Palermo e vedersi in TV, mentre risponde alle domande dei gionalisti e degli spettatori. Um privilegio, in fondo. La possibilita, addirittura, di vivere uma doppia vita". É possibile anche immaginare il sicario, che nascosto sotto una finestra pensa tutto questo, mentre osserva 1'onorevole davanti a sé stesso in tv. Però, queste frasi "pensate" 
dal sicario si contrappongono alla realtà, perché in questo caso la vita (che é somma del tempo e dello spazio) non darà uma nuova chance all'onorevole, invece, gli toglierà tutte.

Dopo questo vengono le frasi detti da un giornalista, che chiede all'onorevole cosa lui farà come vicepresidente della commissione antimafia per prendere Cosa Nostra. L'onorevole non gli risponde subito ma "Sorseggia un'aranciata e sorride ascoltandosi rispondere". È interessante vedere in questa frase la presenza di idee opposte - 1'onorevole sorseggia un'aranciata amara però sorride in seguito, un atteggiamento che ha legame con il suo modo di vivere in cui l'ironia e la bugia sono presenti in tutti i momenti, principalmente in quelli davanti al pubblico. Lo stesso procedimento è fatto con "ascoltandosi rispondere" - tutti sanno che un atteggiamento come questo è praticamente impossibile, nessuno riesce ad ascoltarsi mentre risponde ad una domanda, però nel caso dell'onorevole le cose sono diverse: tutti i suoi movimenti bisognano essere calcolati, perché lui è un uomo politico e perché ha una doppia vita. Le risposte date dall'onorevole sono anche abbastanza interessanti: "Innalzamento della guardia. Denuncia senza rumore. Faremo i nomi dei collusi”. Si può percepire che sono frasi brevi e di effetti, senza nessun approfundamento. L'onorevole non si compromette di niente, non fa nessuna prommessa ed i suoi atteggiamenti sono tipici degli uomini politici che bisognano più di una buona apparenza che delle buone azioni.

Le frasi seguenti confondono i lettori che non sanno bene di chi è la voce, se del sicario, del narratore o del proprio onorevole. Si può pensare, forse, che la frase è dal sicario, che pensa questo mentre osserva l'onorevole: "Funziona. Rielezione assicurata. Specialmente se i voti glieli ha garantiti la famiglia".

L'altra frase, invece, può essere del proprio onorevole, che parla a sé stesso, forse addirittura in alta voce, perché non immagina che c'è qualcuno che 1'osserva: "Trentamila preferenze se ti presenti a Palermo con la patente di nemico numero uno delle cosche e ci cacci fuori dalle palle D'Ottavio".

In seguito ci sono altre frasi che un'altra volta confondono il lettore: "Affare fatto. E adesso, qualche presenza di rito. Cena al Rotary, stasera. Si alza. Stringe il nodo della cravatta nera. In tv ne ha una rossa. Stacca di più. Doppia vita, anche tripla magari. Forse in questo momento una radio privata trasmette una sua intervista. E certo il capofamiglia non sa che lui e D'Ottavio hanno un accordo". Qui si può pensare che è la voce del narratore, però in qualche momento pare che sia il proprio onorevole chi parla, come nella frase "Doppia vita, anche tripla magari".

Dopo c'è nuovamente una frase detta da un giornalista: “Onorevole, non teme per la sua vita ?", qui c'è la presenza dell'ironia, perché in seguito il sicario spara contro 1'onorevole dai corridoi dell'albergo. L'onorevole è morto, però nella tv accesa c'è la sua voce che dice: "Temo di più per le sorti dei valori che rappresento".

Si può pensare che il tema principale del racconto sia il rapporto tra mafia e politica, però ce ne sono altri che appaiono, come: la questione della doppia vita, che è rapresentata attraverso la figura reale dell'onorevole e quella di lui nella tv, la cravatta rossa e quella nera, che forse possono rappresentare anche l'idea di vita (nella tv) e morte (nella stanza dell'albergo); il mass-media, che viene rappresentato attraverso la tv, i giornalisti e l'intervista.

Altro punto interessante è che il doppio viene rappresentato anche attraverso il gioco tra il tempo reale e quello della tv. Questo è più palese nel momento in cui l'onorevole viene ucciso, mentre lui è morto, la sua immagine viva continua in tv.

I temi vengono rappresentati attraverso termini concretti, figurativi, come il proprio onorevole, il sicario ed i giornalisti.

Passando adesso ai personaggi del racconto, abbiamo: 1'onorevole, che non ha nome solo un ruolo sociale, che è quello di vicepresidente della commissione antimafia. Lui è introdotto nel racconto attraverso il discorso diretto del giornalista. La sua morte probabilmente ha legame con la sua doppia vita, lui aveva un accordo con la mafia e questo è saputo dal lettore a causa del discorso del mafioso. L'onorevole è introdotto cataforicamente e va dal meno definito al più definito, quando sapiamo della sua doppia vita. Il giornalista e D'Ottavio invece, vengono introdotti dal discorso diretto e D'Ottavio è l'unico che viene presentato da un antroponimo.

Il narratore è in terza persona, però la narrazione è mescolata tra la sua voce e quella dei personaggi. Lui conosce il pensiero dell'onorevole, ma non degli altri e questo permette la creazione dell'effetto sorpresa. Lui racconta attraverso frasi brevi, veloci ed assindetiche, ossia, si può pensare che l'enunciatore è concitatto.

Analisando adesso il tempo, si può dire che il presente è il tempo principale della narrazione e questo crea l'effetto di realtà; il passato prossimo rappresenta un'anteriorità rispetto il momento di riferimento dell'enunciazione; il futuro viene usato con un senso di certezza, come per esempio nella frase dell'onorevole: "Faremo i nomi dei collusi", un atteggiamento tipico dei politici, che usano ul futuro nei suoi discorsi, passando l'idea di un comprommisso stabilito, di certezza; il congiuntivo imperfetto viene usato nelle paragone, come si vede nella seguente frase: "Come se il tempo e lo spazio offrissero sempre a quelli (...)".

$\mathrm{C}^{\prime}$ è anche l'uso dell'infinito, che forse indica l'idea di stato, come nella prima frase del racconto: "Buffo essere nella stanza (...)"; ed il gerundio, usato nelle azioni in svolgimento, come nella frase: "vedersi in tv, mentre risponde alle domande dei giornalisti (...)".

Lo spazio è anche doppio e si divide tra quello dell'albergo di Palermo e quello della tv. 
Oltre alla questione del doppio c'è un'altra che è anche importante e rappresenta l'oppozione semantiche fondamentale del racconto, che è identità X alterità. Questo viene rappresentato attraverso l'onorevole che utilizza varie "identità" a seconda della situazione in cui si incontra.

\section{(F6)}

Dopo aver letto il poema La poesia oggi, di Sebastiano Vassali, ho pensato tre cose: la prima è che la poesia è nelle cose più comuni, la seconda è che questo poema presenta idee molto attuali e pare che sia stato scritto nel 2006, e la terza, che il poema parla della funzione del poeta e della poesia, ossia è una metapoesia.

A partire da questi pensieri, si può dire che questo poema parla proprio della poesia oggi, della non durevolezza delle cose, del passaggio o dell'efimerità delle cose nella vita, ma è anche uma poesia metaletteraria, perché tratta la funzione del poeta e la letteratura oggi.

Dopo aver fatto una suddivisione della poesia, si percepisce che ogni parte fa riferimento ad universi diversi. La prima parte (che va dal primo al sesto verso), fa riferimento al mondo della poesia e alla vita degli intelletuali ed introdusce il tema principale del poema, trattato nel primo e nel secondo verso della seconda strofa, che è la funzione del poeta e della poesia. Però l'io del poema non dà nessuna definizione su cosa sarebbe questa funzione.

La seconda parte della poesia (che va dal settimo al penultimo verso), parla della poesia in un posto più comune, della vita moderna e dell'universo del consumismo. Però ci sono tre versi (il primo, il secondo ed il terzo verso della quarta strofa), che fanno uma suddivisione in questa parte, perché parlano della poesia classica. È interessante osservare che in questi tre versi il tempo verbale usato è il passato remoto, e questo va d'accordo alla tematica trattata, che è la poesia classica.

Poi, il poema ritorna al tema della banalizzazione delle cose nel mondo contemporaneo fino alla fine.

Sono anche interessanti gli elementi del poema che fanno riferimento al tempo, come gli avverbi di tempo "oggi" e "già", l'aggettivo "lontano" ed i tempi verbali usati, che sono: il presente (prima, seconda, terza e quarta strofa), il condizionale (seconda strofa), il passato remoto (terza strofa), il gerundio (terza strofa) e l'infinito (seconda, terza e quarta strofa).

Si può dire adesso che nel poema abbiamo 1'uso prevalente del tempo presente, che forse, riguarda al mondo contemporaneo e al posto della poesia oggi. Questo però, si contrappone all'uso del passato remoto che riguarda la poesia classica, ispirata negli ideali più lontani e irragiungibili.

Altro elemento interessante da osservare è 1'uso dell'avverbio di tempo "oggi", che può essere riatualizzato e quindi riguarda tanto l'epoca in cui è stato scritto il poema (1972) siccome i giorni attuali. È anche um elemento enunciazionale perché si riferisce all'io che parla.

Gli elementi che si riferiscono allo spazio sono anche interessante da analizzare. Nella prima strofa abbiamo "ovunque", "questo paese", "attorno a "tavole rotonde"; nella seconda strofa: "al cinema", "nei grandi magazzini” e nella "nella facce della gente"; nella terza strofa: "nel cuore del poeta" e nella quarta strofa "entra al supermercato".

Dopo aver individuato ognuno di questi elementi si può dire che c'è una specificazione dello spazio, che comincia con "ovunque" e finisce con "entra al supermercato", in una specie di gradazione che va dal maggiore al minore e più specifico spazio.

L'altro elemento importante da osservare è la persona, chi parla e di chi. Nella prima e terza strofa abbiamo 1'uso della terza persona; nella seconda strofa appare la prima volta un "io" in "saprei dire" e "io la posso indicare" e nella quarta strofa abbiamo l'ultimo verso che si stacca dagli anteriori perché pare un discorso diretto o una figura di linguaggio.

Si può dire che 1'uso della terza persona indica un allontanamento, mentre l'uso dell'io indica un avvicinamento di questo "io" del poema verso i lettori.

Quest'ultimo verso è interessante perché provoca un dubbio nel lettore. Non si sa bene se è un discorso diretto o se si collega alla seconda strofa. Secondo me, questo verso farebbe più senso se collegato al secondo verso della seconda strofa. Così, sarebbe come uma specie di continuazione dei due versi della seconda strofa: "Della funzione del poeta non saprei dire nulla / La poesia oggi - la gente guarda e tace, entra al supermercato". I versi così cambiati hanno collegamento all'idea di consumismo del mondo attuale, in cui le persone non danno più valore alle cose astratte come la poesia, ma sì ai produtti che servono per ingrandire e valorizzare la propria immagine.

Quest'ultimo verso così spostato alla fine del poema fa ricordare al lettore 1'anacoluto, una figura di linguaggio che rappresenta un pensiero. Così, possiamo dire che tutti i versi che sono tra il secondo verso della seconda strofa $\mathrm{e}$ 1'ultimo verso del poema, sono una specie di interferenza del pensiero dell'io del poema.

È interessante osservare anche la ripetizione delle parole "poeta" e "poesia" nel poema, che svuota il significato di queste parole. Alcune volte queste appaiono tra virgolette e questo crea una specie di ironia e può servire tanto per ingrandire i poeti del passato siccome per indicare che oggi le cose si sono cambiate, perché il poeta e la poesia hanno perso il significato di prima, essendo a volte inutili. 
Però, si può dire che la poesia oggi è più libera che quella di prima, perché non segue più $i$ canoni degli intelletuali, come la poesia classica.

Le "tavole rotonde" appaiono anche tra virgolette e questo, secondo me, indica Che hanno um doppio significato, perché le tavole rotonde oggi hanno un significato banale, mentre nel passato serviva a discussione su cose importante siccome la letteratura, la politica, ed erano responsabile per cambiamenti nella società.

Questo si collega anche alle figure centrali che appaiono in questa poesia. Secondo me, una delle immagini più importanti è il "cuore del poeta" perché sintetizza in sé il tema della funzione del poeta nel tempo della poesia classica, che si contrappone alla banalità e alla banalizazzione della poesia nel mondo contemporaneo.

Secondo me, si può dire che gli stratagemmi usati nel piano dell'espressione siccome la rima di "vinello" e "suggello", "lontano" e "toscano", l'assonanza della lettera "n" e l'enjambement, servono a creare effetti di suono e di forma che esaltano la ricchezza del tema trattato.

\section{ALUNO G}

\section{(G1)}

Il titulo "Luca non dimentica": quando un patto con il destino è fato, il destino non dimentica.

Il primo paragrafo è piu tenso che il secondo per che in el secondo Luca ha passato il sua responsabilidade per il destino.

Il texto è basato su la memoria e la dimenticanza perche Luca aveva una buona memoria e non ce l'há piu. L'uso delle espressioni "memoria d' elefante" e "colabrodo" provaca l'effeto di elementi contrapposi.

Il discurso diretto crea un effeto di illusione della realtá.

Le espressioni riferite al tempo provocano l'effetto che il tempo passa e il non ricorda della parole, c'è una contraposicione com preterito imperfeito e presente.

\section{(G2)}

Questa poesia sembra un dialogo, in cui il discorso diretto crea le efetto de veracità. A desiluzione amorosa, nascita e separazione sembra essere il tema princiapale di questa poesia. Un uomo chi parla con sua moglie della nascita del loro figlio senza molto entusiasmo. Questo uomo non consegue si prender in una relazione. I due piani temporali del presente e del passaro sembr una mudança in la sua vita. Il "io lirico" parla con qualcuno di sua moglie in tono sarcastisco e ironico.

\section{(G3)}

Nel racconto "Occhi di Paola", ci sono diversi elementi contrapposti: chiaro/ scuro, tranquillità/peccato, assoluzione/punizione, azzurro/grigio, coscienza/rimorso e innocenza/colpa. Siccome il tradimento e il pentimento sono i temi del racconto, questi elementi contrapposti sono fondamentali per capire la problematica narrata.

Nella costruzione del testo partecipano le "voci" implicite e le "voci" esplicite. La "voce" esplicita è il discorso diretto dei personaggi che ha la funzione di creare un effetto forte e concreto di sentire le voci dei personaggi.

L'altro strategemma narrativo usato è il discorso indiretto libero quando è narrato il pensiero di Duccio ("...Si può tradire e farla franca...”). Nel discorso indiretto libero, la mancanza della virgolette elimina la barriera messa tra narratore e personaggio e anche il narratore assume la responsabilità di quello che è detto. Quando l'enuniciatore riporta questo pensiero, l'enunciatore lascia che la "voce"del personaggio invada il campo del narratore. Dunque, come non c'è un soggetto espresso e il tempo verbale usato è un presente onnitemporale, non abbiamo un unico responsabile per questa affirmazione.

L'onniscienza del narratore viene fuori anche nella descrizione degli occhi di Paola. L'elemento centrale del racconto sono gli occhi. Però, gli occhi non appaiono perché sono nello scuro o sono nascosti dalle palpebre.

Il colore degli occhi di Paola incorpora la contrapposizione tra azzurro e grigio. L'azzurro può essere messo in relazione agli aspetti positivi come la felicità, invece, il grigio è messo in relazione agli aspetti negativi. Dopo avere saputo "dell' incubo" di suo marito, gli occhi di Paola diventano grigi.

La descrizione fisica di Paola è una descrizione euforica visto che prima si può pensare a una bella donna, dopo questa bellezza è accentuata dalla nozione del tempo. Quindi, c'è un'altra contrapposizione: vecchiaia e giovanezza. Per creare l'effetto di senso della verità e dell'oggettività, ci sono antroponimi e crononimi. Gli antroponimi sono i ruoli sociali dei personaggi (marito e moglie) e nelle caratteristiche (occhi azzurri, guancie piene e morbide, capelli scuri). I cronomini sono vent'anni prima e la locuzione temporale da due ore. Quanto maggiore la catterizzazione dei tempi e dei personaggi, ci si avvicina alla realtà. 
Il presente è un altro strumento che viene usato per concretizzare l'idea di realtà come se il narratore dicesse quello che vede.

Il secondo paragrafo inizia con Non l'ha più fatto, l'uso del passato prossimo avvicina il "non tradimento" al presente. Invece, il passato remoto è il tempo del tradimento che crea un allontamento del momento presente. Il protagonista maschile è introdotto cataforicamente con "lo" tormenta per creare l'effetto di curiosità e di attesa nel lettore. Questo è un stratagemma che permette un' anticipazione di elementi che non sono stati ancora citati.

\section{(G4)}

La poesia comincia con la congiunzione condizionale "se" che introduce un periodo ipotetico della possibilità e sostiene tutta la costruzione del testo. Il "se" è la prima parte della poesia che costituisce la condizione, la protasi, comincia con il condizionale "se", si sviluppa con i congiuntivi imperfetti e finisce con il participio passato "successo". La seconda parte si chiama, invece, apodosi ed è la conseguenza del periodo ipotetico introdotta dal condizionale "sarebbe" e che finisce con il sostantivo maschile singolare "successo". Quindi, sia la protasi che l'apodosi terminano con la parola "successo". Quest'uso polisemico di "successo" ricollega le due parti del poema accentua la sonorità. Le azioni del "tu" che sono seguite dalle parole "amore mio che è successo?" sono così rare come un "pezzo di teatro di successo".

Sul piano dell'espressione, vengono usati stratagemmi come l'alliterazione in "ss" che crea un effetto di sussurro. L'assonanza in " $i$ " si congiunge alla doppia "ss". La rima è poversa, crea, però, un effetto particolare, dando enfasi alla parola "successo".

La scelta di usare il periodo ipotetico mette in evidenza il tema del poema che è l'impossibilità dell'amore nel piano dell'arte (sia nella poesia sia nel pezzo di teatro). I due avverbi di tempo "ora" e "poi" inseriscono nella poesia un legame con il momento di riferimento temporale presente, l'enunciazionalità, però questo "ora" non è effettivo visto che è in un periodo ipotetico. "Poi" indica una successione temporale confermata da "ora" e una continuità delle azioni ipotetiche che è anche enfatizzata dal connettivo " $\mathrm{e}$ ". L'uso del connettivo " $\mathrm{e}$ " nel secondo, terzo, quarto verso crea un effetto di attesa nel lettore che è eliminato dal "senza" e pois ripreso dall'"e" nel sesto verso quando culmina nel discorso diretto.

Il discorso diretto "Amore mio, ma che è successo?" rinforza l'immagine teatrale ipotetica, dando una voce al tu imaginario. Il "tu" implica un "io" che viene confermato dal pronome possessivo "mia" nel primo verso. Il discorso diretto stacca il "tu" dell'ipotesi perché questo "tu" dice, agisce e ha una manifestazione di sorpresa nei confronti di una situazione inaspettata "Amore mio, ma che è successo?". Quindi, con il discorso diretto questo "tu" ha una concretezza e anche un rapporto amoroso con l'io. La scelta lessicale "amore mio" e "bacci" pressuppongono una relazione intima tra loro. Però forse questa intimità è anche ipotetica perché è un desiderio dell'io. La parte finale "un pezzo di teatro di successo" dà un senso alle ipotesi create.

I soggetti dell'enunciato sono messi in evidenza attraverso gli elementi: tu, mia, tia, io, miei, tu, mia, mi e mio. Mentre lo spazio interno e esterno viene introdotto da porta e bocca. Le azioni che vengono dopo gli avverbi di tempo "ora bussassi alla mia porta" e "poi entrassi dentro la mia bocca" creano un effetto di movimento da fuori a dentro. La porta e la bocca hanno una funzione equivalente perché sono limiti del dentro e del fuora, oppure del pubblico e del domestico. Gli occhiali che rappresentano 1'esteriorità sono uguali, quindi c'è un 'armonia nella parte esteriore. Però, nella parte interiore rappresentata dalla bocca c'è una disuguaglianza. Quest'ugualianza esteriore e questi baci che partino dal presupposto che sono disuguali possono essere una metafora dell'omosessualità.

Le figure creata da "entrare dentro la bocca" e " toglere gli occhiali" possono significare la necessità di togliere la maschera per raggiungere l'anima. Le parti del corpo umano vengono citate attraverso gli occhiali (come si vede il mondo), bocca in cui si entra con i baci, la mano per bussare la porta e l'udito (rumore del bussare). Queste parti del corpo fanno riferimento ai sensi perché per avvicinarsi a una persona è necessario usare i sensi.

\section{(G5)}

La narrazione è in terza persona e il suo tempo principale è il presente. La scelta del presente è per creare l'ilusione di contemporanietà e di parlare in presenza del lettore. Come se la situazione fosse ritualizata tutte volte che viene letta. Il narratore in alcuni momenti osserva le scene e anche le giudica: "La voce dalla schermo non si incrina". Le voci del narratore e del personaggio si mesclano e cosí, mette in evidenza i pensiere del personaggio. Però, il narratore non è onnisciente perché non mette in evidenza i pensieri degli altri personaggi. La mescolanza delle voci sono una maniera di rinforzare il tema del doppio.

Il tema principale è il rapporto tra la mafia e politica e viene introdotto dal proprio titolo "Onorevole doppia chance". La parola "onorevole" è un elemento di congiunzione tra le due ambiti tematici: la mafia e la politica. Perché "onorevole" richiama non solo il ruolo politico del personaggio, ma anche l'idea dell'uomo di onore della mafia. Altri temi che vengono collegati ai temi principali sono il tema della mass media e del doppio. 
Il tema del doppio causa un'ironia perché la voce del personaggio continua anche dopo la sua morte. Tutto il racconto è costruito sul tema del doppio. L'attorializzazione, la temporalizzazione, la spazializzazione e il lessico rinforzano questo tema. La morte del personaggio mette in evidenza il sistema della mafia dove tutti sono furbi e vittime allo stesso tempo.

L'uso del gerundio e infinito danno più possibilità di interpretare il racconto. Perché... [sic]

Le scelte lessicale (isotopie) hanno relazione con i temi del testo. Per esempio, attraverso la figura concreta del giornalista, degli spettatori e della tv viene esplicitato il tema della mass media. Le scelte lessicali sono essenzialmente i concetti. Quindi, il testo è figurativo perché fa riflettere i suoi concetti a partire di una figura.

Le azione del testo di svolgono in due luoghi: nell'albergo e nella tv. Lo spazio viene verbalizzato nel testo "lo spazio offrissero sempre a quelli come lui una scappatoia". Questi due luoghi possibilitano 1'ubiquità del personaggio che è essenziale per capire la doppia vita dell'onorevole.

\section{(G6)}

Dopo aver letto la poesia, tre temi vengono in mente: i luoghi in cui si trova la poesia, la poesia nella società e la funzione della poesia oggi. Tutti questi temi sono colegatti al tema generale che è la poesia nel sistema capitalista.

La poesia può essere divisa in tre parti che riportano ad universi diversi. La prima parte và dal primo verso fino al sesto verso in cui c'è una reflesione sullo studio della poesia e la funzione del poeta oggi. La seconda parte và dal setimo verso fino al penultimo verso e c'è una contrapposizione tra la poesia del passato e del presente e dei atteggiamento della società verso alla poesia. La terza parte è l'ultimo verso che può essere interpretato di due modi diversi: come un discorso diretto e, quindi un'altra voce che ha la funzione di rinforzare e concludere tutto ciò che è stato detto prima dall'enunciatore, oppure come una parte collegatta al sesto verso dal travessione.

$\mathrm{Ci}$ sono molti avverbi, aggettivi e tempi verbali che si riferiscono al tempo. Nella terza strofa, per fare una contrapposizione tra passato e presente, vengono usati il passato remoto morirono e vissero e l'aggettivo lontano. L'avverbo oggi che fa parte del titolo è uno stratagemma per ritualizzare la poesia tutte le volte che viene letta perché oggi è enunciazionale e, quindi, si riferisce al momento dell'enunciazione. I deitici Oggi e questo paese non vengono determinati, di conseguenza, lasciano interpretazioni varie ai lettori.

La specificazione dello spazio viene specificata di più. Comincia da ovunque, poi questo paese fino a tavole rotonde. Le virgolette usate per le tavole rotonde possono richiamare all'idea della tavola rotonda di Arthuro. Così come i cavaglieri discutivano le strategie, gli studiosi discutono poesia.

La poesia è predominantemente oggettiva però ci sono due versi in cui è la prima persona chi parla. La terza persona discrive il rapporto degli studiosi con la poesia nella prima strofa. Nella seconda strofa, la persona chi parla è un io che parla del suo rapporto con la poesia. Nelle altre strofe, c'è l'oggettività della terza persona che fa vedere la contrapposizione tra poesia del passato e contemporanea e il rapporto della poesia con il consumismo. La scelta lessicale sono del universo del consumo e la poesia finisce con la parola "supermercado" il luogo dove si trova mercatorie.

Le figure centrali per l'interpretazione della poesia sono delle famose cortigiane perché rappresentano la banalizzazione delle persone e dell'ideale nella società di consumo in cui tutto deve avere un'utilità sia risciaquar pavimenti sia sturare un lavabo. A causa di questo utititarismo, la poesia viene ignorata perché non ha una funzione pratica.

\section{ALUNO H}

\section{(H1)}

In questo testo ci sono due elementi contrapposti che tormentano il protagonista: aveva una memoria molto buona, però, adesso ha una pessima memoria. Con appena trent'anni lui non accetta la perdita della memoria. Tenta inventare un sistema che la induca a funzionare. Tenta vincere lo tempo, fa un patto con il destino. Tutto per ricordare un nome. Nel momento in che ricorda il nome, Luca, felice e esausto, è morto per un'auto in mezzo alla strada.

\section{(H2)}

C'è un passaggio di tempo nella poesia, i avvenimenti non succedono nello stesso giorno. Nella prima parte della poesia c'è una donna che ha partorito, il primo dialogo di questa poesia sembra essere della donna con il narratore: "Come va"/ " Non c'è male". Dopo il narratore dice che "l'ho sposata". Quindi il narratore è sposato con questa donna con chi parla. 
Il secondo dialogo sembra essere in un'altro giorno e con altra persona, forse del narratore con un amico, loro parlano probabilmente della vita di sposato. L'amico domanda com'è andata la vita di sposato e lu risponde ironicamente che è andata via. Questa ironia fa pensare che lui è stato lasciato per sua moglie ma che non `e contento per questo, perciò lui l'ho sposata ancora, probabilmente è sposato con la stessa donna perché la ironia che ha fa pensare che è una persona vendicativa. Dunque lui è sposato con la stessa donna per vendetta, lui le convince di sposarsi di nuovo per fare con lei la stessa cosa che ha fatto con lui.

Dopo sposarsi di nuovo, in un'altro dialogo qualcuno domanda "Come va" e lui risponde appena "Va", questa risposta corta indica che il matrimonio continua ma non dice se bene o male.

Dopo lui dice: "ho lasciato anche lei", se lui dice che il matrimonio va è perché, forse, sua moglie non sa ancora che lui ha l'intezione di partire, il matrimonio continua fino a quello momento.

Tutta la poesia è scritta nel tempo verbale passato, soltanto l'ultimo verso, "parto alle sei”, è nel presente, questo fa pensare che è decidito partire ma che nessuno sa di questa sua decisione perché in questo modo la sua vendetta sarebbe perfetta.

\section{(H3)}

"Occhi di Paola" è un racconto che tratta del tradimento. Gli occhi di Paola appariscono nel racconto due volte come "occhi azzurri" che diventano "ingrigiti", questa descrizione rimette ad una immagine e non precisamente della alterazione del colore degli occhi, c'è una associazione tra elementi positivi ed elementi negativi nell'uso di questa immagine, per esempio il cielo azzurro quando il giorno è belo e c'è il sole, ma diventa grigio prima di una tempesta quando il giorno diventa brutto, freddo e triste.

C'è uma frase del scrittore Aphonse Karr che spiega l'uso di questa immagine: " Gli occhi sono la finestra dell'anima". Paola porta nella sua anima qualcosa di negativo. Questo grigio degli occhi di Paola può significare molte cose che saranno sempre negative, come: desiderio di vendetta, tristezza, malinconia. Si può anche notare un'associazione com altri elementi negativi nel testo come: la bugia, il tradimento, il rimorso, la colpa, ecc.

Paola è stata traditta da Duccio da venti anni, si può immaginare che lei sospettava del tradimento di suo marito ma non aveva mai buscato uma conferma, ma questa sospetta la tormentava di giorno in giorno. Gl'ingrigi degli suoi occhi forse fosse l'unica manifestazione di suo risentimento, non si sa molte cose rispetto a sua personalità per questo non si sa qual'è il significato di questo "grigio degli occhi".

Duccio, marito di Paola, non dimostra nessuno tipo di pentimento per il suo tradimento finché in uma notte non può dormire e non capisce perché e solo dopo riparare in Paola che dormiva vicino a lui e ricordare il dettaglio degli occhi capisce che cosa lo tormenta. Sembra una associazione incosciente tra il grigio degli occhi di Paola e il tradimento perché lui pensa che lei non sa la verità ma il suo incosciente è pieno di pentimento e all'improvviso viene la colpa e un bisogno di si redimere. Duccio pensa solo nella tranquilità della sua coscienza e inventa una bugia, trasforma la vera storia del tradimento in un incubo, Paola sembra fingere credere, lo dice: "Grazie per averlo chiamato incubo". Non si sa com'è il rapporto di Paola e Duccio, non si sa qual'è la personalità di Paola, l'unica cosa che si può sapere è che lei passa per un tipo di trasformazione, per questo la frase "Grazie per averlo chiamato incubo" può significare cose diverse: può essere conformità, se lei già sapeva e aspettava un indizio di pentimento di suo marito, ma può anche significare ironia, se lei già sapeva ed aspettava uma conferma del tradimento per decidere cosa fare. Nel primo caso, il "ingrigi degli occhi" rapresentano malinconia mentre nel secondo caso rapresentano desiderio di vendetta.

"Occhi di Paola" è un racconto narrato nella terza persona singolare ed il narratore non ha un rapporto diretto con i personaggi della storia, per questo sua narrazione è imparziale. Il tempo verbale del racconto è il presente che crea un effetto di vicinanza tra il lettore ed il testo ed anche di verosimiglianza. Informazioni come il nome dei personaggi, $\mathrm{i}$ luoghi ed il tempo dove succedono i fatti, tutti i tipi di descrizione e l'uso del discorso diretto è un stratagemma narrativo che rinforza l'effetto di verosimiglianza.

Il racconto inizia con la frase: "Non può dormire", non si sa chi è la persona di chi si parla, i dettagli sono rivelati a poco a poco, questo crea un effetto di sospense che si mantiene dell'inizio alle fine del racconto.

\section{(H4)}

Il poema espressa il desiderio di un"'io" rispetto ad un "tu", questo desiderio si concretizza soltanto attraverso l'immaginazione dell'io, per questo l'intero poema è basato su una situazione ipotetica, la quale giustifica l'uso del congiuntivo imperfetto e del condizionale.

L'uso del periodo ipotetico stabilisce uma struttura di prima e dopo nella quale si configurano azioni seguenziali, l'uso della congiunzione "e" rinforza l'effetto di successione, ogni azione ne scatena un'altra. Questa idea di prima e dopo viene espressa nel poema attraverso l'uso degli avverbi "ora" e "poi”. 
L'immagine che divide il poema in prima e dopo è quella del "togliere gli occhiali", a partire di quest'immagine si definisce la scelta del lessico, ad esempio dei verbi "bussare" e "entrare" che collegati alle parole "porta" e "bocca" attribuiscono significati specifici. Prima di "togliersi gli occhiali" si "bussa alla porta" e dopo "si entra nella bocca", il bussare alla porta rimette ad un'idea di pudore e di prudenza mentre "entrare nella bocca" rimette a un'idea di una maggiore intimità e dell'assenza del pudore.

L'immagine degli occhiali, che rimettono all'idea di vista, significa o equivale in questo poema al modo di vedere le cose e, come abbiamo già visto prima di togliersi questi occhiali c'è un pudore maggiore che si perde dopo esserli tolti, si può concludere, pertanto, che "gli occhiali" rappresentano forse un modo moralistico di vedere le cose.

Il poema stabilisce una disugualianza tra l'io e il tuo, uma disugualianza basata sul tema dell'amore, si può capire questo attraverso il verso: "senza temere baci disuguali", la parola "disuguali" di questo verso contraddice la parola "uguali" che si riferisce agli occhiali, pertanto il tu e l'io hanno lo stesso modo di vedere il mondo e se cambiassero il punto di vista i baci sarebbero uguali, loro sarebbero uguali nell'amore. Di questo si può dire che l'io è uma donna e il tu è un uomo q quel modo di vedere il mondo (gli occhiali) è il maschilism. Secondo le convenzioni sociali, in una società maschilista, le donne dimostrano l'amore in un modo diverso degli uomini. Questo si conferma nell'espressione in discorso diretto: “Amore mio, ma che è successo?”, quest'espressione mostra la coscienza dell'io ( la donna) che la sua atitudine sarebbe strana per il tu (l'uomo), perché non corrisponderebbe ai modelli sociali.

Alla fine del poema, la conclusione che tutto questo che l'io immagina "sarebbe un pezzo di teatro di successo", rimette all'idea che questa situazione non potrebbe succedere davvero, l'associazione della situazione di uguaglianza tra la donna e l'uom (l'io e il tu del poema) sarebbe finzione, come un pezzo di teatro.

\section{(H5)}

Questo racconto tratta di un tema polemico: quella della questione del coinvolgimento della mafia com la politica, per questo è costruito su immagini doppie che rimettono al tema principale.

Si può identificare la duplicità tematica già nel titolo "L'onorevole dopiia chance", la parola "onorevole" rimette al tema della [mafia] e a quello della politica allo stesso tempo perché contiene in maniera implicita la parola "onore" che è tipica del lessico dei mafiosi ( ad es.: "uomini d'onori”) ed anche perché è parte del lessico politico: onorevole = deputato. Ma si può identificare la duplicità soprattutto attraverso l'analisi del personaggio perincipale.

Il personaggio non viene presentato attraverso un nome, ma soltanto attraverso quello che rappresenta nella società: un uomo che vive uma vita doppia tra l'illegalità della mafia e la politica. Fin dall'inizio viene presentato come qualcuno che há "il potere", per esempio attraverso la parola "onorevole" che rimette all'idea di esclusività. Quest'immagine del potere viene rinforzata dall'inizio alla fine del testo: "Un privilegio, in fondo. Come se il tempo e lo spazio offrissero sempre a quelli come lui uma scappatoia", in questo brano si può identificare elementi essenziali: la parola "privilegio" che rimette, come la parola "onorevole", all'idea di esclusività e la relazione di questa parola com "tempo" e "spazio" che rappresentano uno stratagemma dell'enunciatore nella costruzione formale del testo.

A quello che riguarda allo spazio si può osservare che le azioni succedono in due luoghi diversi: nella Tv e nella stanza di un albergo. Si può identificare un comportamento ironico del personaggio principale com relazione al suo modo di vita, vedendosi nella TV l'Onorevole trasmettere una sicurezza di chi non sarà mai scoperto: " Sorseggia un'aranciata amara e sorride ascoltandosi rispondere: sicuro di sé, sguardo deciso, ciuffo kennediano sulla fronte”.

L'ironia del testo è rinforzata dalla rappresentazione temporale, il rapporto tra prima e dopo viene stabilito attraverso l'immagine della vita e morte del personaggio principale ed è fondamentale per rinforzare questa idea d'ironia ed anche di potere.

La morte che sarebbe stata l'unica maniera di finire con il potere dell"'Onorevole mafioso" è “vinta" dall'ubiquità della TV accesa che assicura l'idea di potere che è intorno al personaggio centrale fin dall'inizio del testo e ne garantisce anche l'ironia.

Il testo è predominantemente figurativo e ha assicurato uma certa imparzialità dell'enunciatore davanti ad un tema così polemico quello della mafia ed il potere costituito e delle regole che esistono tra quelli che sono parte di questo mondo.

\section{(H6)}

La poesia oggi di Sebastiano Vassalli è un testo metaletterario, una riflessione sulla poesia attraverso i versi. Si può affermare che intorno alla riflessione sulla poesia i tema principali sono: una critica alla società di consumo ed anche l'isolamento dei poeti .

Il testo viene sviluppato in un modo che gradativamente passa da quelli che producono e valorizzano ancora la poesia a quelli che sono indiferente alla poesia, nella prima strofa abbiamo:"Ci sono persone ovunque che scrivono la poesia oggi", e nell'ultima abbiamo: "La gente guarda e tace, entra al supermecato", questo stabilisce un rapporto 
inesistente tra pubblico ed opera e costituice un paradosso a quello che riguarda all'esistenza dell'opera d'arte, principalmente alla poesia che è un'arte che si propone universale.

La critica alla società capitalistica viene esplicitata nei due ultimi versi della seconda strofa, nei quali l'enunciatore dice dov'è la poesia: "Sta nei grandi magazzini, nei settimanali illustrati/ Nella pubblicità al cinema, nelle facce della gente" d'altra parte quelli che scrivono la poesia "siedono attorno a 'tavole rotonde'/ prendono e danno premi", ossia, sono isolate rispetto al pubblico, loro producono e loro stessi giudicano le sue opere, si bastano. La poesia finisce giustamente con l'indiferenza della gente, il pubblico, rispetto alla poesia. A questo punto si può affermare che il buco tra il pubblico e la poesia è occupato oggi per il consumismo, la letteratura ha perso la forza di trasmettere qualche valore alla società perché subì l'imposizione del mercato e diventò un produto.

Già dal titolo si stabilisce uno scontro tra un passato e un presente che non riguardano necessariamente a date fisse ma che si può leggere come uno scontro fra "tradizione" e "modernità". L'avverbio "oggi" pressupone un "ieri". L'enunciatore fa, appunto, un'allusione al modo di fare poesia nel passato nella terza strofa, in questo punto il tempo verbale, che fino alla seconda strofa è il presente, cambia e diventa passato remoto: "Che instillarono nel cuore del 'poeta' l'Ideale lontano/ per cui in milioni morrono o delirando vissero[...]", a partire di questa risorsa l'enuciatore stabilisce un paragone tra "ieri" e "oggi".

Si può concludere che l'esistenza della poesia dipende della necessità di scrivere, di esprimirsi, però dipende anche di un rapporto tra l'opera ed il pubblico, e questo dipende dei valori accetti dalla società.

\section{ALUNO I}

\section{(I1)}

Il protagonista si chiama Luca. Sono personagio anche un'auto il destino.

Luca ha trent'anni. Aveva una memoria d'elefante, adesso è un colabrodo.

Il ricordo è ilemento positivo per reconoscimento della società.

L'uso delle due metafore (memoria d'elefante i colabrodo) riforza la expressioni e il contrasto.

Luca fa un patto con il destino. "Si non mi viene in mente prima delle sei, allora morirò entro un anno" (voglia ricordare un nome).

Nel testo ha exprissioni riferite al tempo che provocano l'effetto di fuga di tempo. "Guarda l'orologio", "le sei meno un quarto".

Altro effetto che ha nel testo è che stamo di fronte con persone che parla. Questo crea effetto di realità, che l'autore fa utilizzando la strategia del discorso direto.

Nel finale del racconto, lui ricorda il nome e un'auto lo travolge.

\section{(I2)}

Le prime impressione della lettura fanno capire che la poesia è strana. Sembra un mescuglio di dialoghe (molte persone parlano), ma questo non è giusto.

Dopo capiamo che ha un tema: l'amore finito, segragazione.

Ha due persone che parlano: un uomo che sembra essere molto freddo (ha lasciato sua moglie e suo figlio), ed ironico (lui ha sposato altra moglie e ha lasciato anche lei) e altra persona che non sappiamo se è un uomo o una donna. Ma l'ironia sta anche in stratagemmi particolari, la poesia gioca sul doppio significato del verbo andare.

L'altra persona (quella che non sappiamo se è un uomo o una donna) chiede come va la moglie dell'enunciatore e lui dice che lei è andata e un po' dopo dice via.

Lui gioca con i due significati di andare che sono stare e caminare.

Questo dà un effetto umoristico e mostra la natura ironica dell'enunciatore.

Hanno altri stratagemmi nella poesia.

L'enunciatore quando decide di introdurre il discorso diretto che crea un effetto di realtà, l'iluzione di ascoltare da vero una cosa detta e ha, anche, un altro gioco con due piani temporale del presente e del passato: nello discorso diretto è il presente e nello indiretto il tempo è il passato. Questo stratagemma crea un effetto di approccio dei fatti dello discorso diretto e lascia lontani gli altri.

Sul piano dell'espressione la poesia usa rima (partorito/ partito), assonanza ( $\underline{\text { allora/ }}$ ancora) e alliterazione (ospedale, sposata). Questo dà un affetto sonoro alla poesia.

\section{(I3)}

Questo titolo, "occhi di Paola", fa pensare che il racconto è una storia su una testimone, o una persona che vede cose che le altre persone non vedono (potrebbe essere un racconto soprannaturale). 
Potrebbe essere anche un racconto sull'amore, ma non è esattamente così.

Dopo la lettura del testo sappiamo che il tema del racconto è il tradimento.

Fanno parte del racconto, anche, idee sulla coscienza, sulla colpa e sulla punizione.

Nel testo c'è un narratore, ma quello che narra non è personaggio, è un narratore implicito (non si può vedere la persona che narra) in terza persona.

Il narratore quando introduce il personaggio principale (che si chiama Duccio) usa già uno stratagemma.

Prima è introdotto un personaggio che non si vedi il suo nome, è soltanto "lui".

Dopo, alla quinta riga il narratore dice il nome del personaggio che è Duccio.

Questo stratagemma (usa un pronome prima e dopo il nome) si chiama catafora (e perché non sappiamo il nome del personaggio vogliamo sapere chi è).

Ci sono altri attori nel testo che sono Paola, Franca e Giorgio.

I personaggi hanno nomi propri (antroponimi) e questo crea l'illusione di ancoraggio alla realtà.

C'è un altro stratagemma responsabile per l'ancoraggio alla realtà che è l'uso del presente.

L'uso del presente crea anche un effetto di simultanità (il narratore sembra essere un osservatore della scena che include il lettore alla storia, perché è come se il lettore vedesse la scena insieme al narratore).

$\mathrm{Ci}$ sono nel testo tre piani temporali che sono usato per l'interpretazione.

Il presente ed il passato prossimo parlano della vita di Ducio negli vent'anni dopo aver tradito Paola: questo avvicina i fatti dopo il tradimento (e questo è più importante).

Quando parla del tradimento, il verbi sono al passato remoto e questo alontana il fatto (il tradimento non è importante, molto tempo fa).

Nel testo c'è anche, un'altra strategia che è il gioco sulle coppie di elementi contrapposti: la coscienza tranquilla ed il pentimento; il chiaro e l'oscurità; l'assoluzione e la punizione; i colori azzurro e grigio.

Questo gioco sugli elementi contrapposti è usato, anche, nella descrizione fisica di Paola: lui ha vecchiaia e giovinezza (ha occhi azzurri, ma ingrigiti, ha capelli neri, ma ora tinti).

Il gioco sullo scuro (usato come elemento antitetico) fa, anche, il tono del racconto (tono di dubbio).

All' inizio del racconto c'è una semioscurità ed in questo brano c'è un piccolo dubbio su che cosa succederà nella storia.

Alla fine, quando sappiamo che cosa è successa (o pensiamo a sapere) c'è l'oscurità e dopo questa parola (oscurità) non sapiamo più la fine del racconto (se Paola sa qualcosa sul tradimento).

Il buio si riferisce al titolo del racconto: prima gli occhi di Paola non si vedono perché sono nascosti dalle palpebre, dopo perché sono nell'oscurità.

Il dubbio (rappresentato dall'oscurità molte volte) esiste anche sull'opinione dell'enunciatore (prima si pensa a facerla franca come una cosa possibile, dopo si vede che non è proprio così).

\section{(I4)}

Dopo aver letto la poesia vengono in mente tre possibili temi: la poesia si riferirebbe a un rapporto amoroso. Sembra che questo tema sia il principale, ma potremmo anche leggerla in maniera allegorica e così il tema potrebbe essere sia il futuro che il processo di scrittura.

Quando pensiamo alla poesia come a una rappresentazione del futuro, il futuro sarebbe un "tu" che arriva pieno di forza, un "tu" che non si può controllare. Quando ci pensiamo come un testo sul processo di scrittura, pensiamo all'immaginazione come una forza che può fare paura, ma può mostrare cose interessanti ("sarebbe un pezzo di teatro di successo").

Ci sono però molte cose che mostrano che la poesia sia un testo sull'amore. Se ci pensiamo così, ci sono molte parole che rappresentano elementi di un rapporto amoroso.

Ci sono un "io" ed un "tu" che vengono alternati. "L'io" si riferisce al "tu" in modo intimo, sembra che abbiano o almeno che "l'io" vuole che abbiano un rapporto amoroso.

Questo "io" parla in maniera veloce, c'è la brevità nel testo, che non è molto convenzionale. Questo stile fa capire che "l'io" sia una persona a cui piacciono le cose forti, sembra che sia una persona emotiva, passionale.

Il primo elemento interessante è "alla mia porta" che si refirirebbe all'intimità perché la porta si è chiusa, lascia fuori tutto quello che non si vuole.

Un altro simbolo potrebbe essere quello degli occhiali" che sarebbero un simbolo delle maschere sociali, perché sono un oggetto posto davanti agli occhi che rappresentano l'anima. È interessante osservare che le maschere, i pregiudizi, sono uguali.

I "baci disuguali" si riferirebbe all'intensità dei sentimenti (chi ama di più o di meno).

C'è un altro dettaglio interessante. Il testo è iniziato davanti all'interlocutore, si avvicina ( "alla mia porta") e quasi alla fine si è dentro l'interlocutore ("entrassi dentro la mia bocca"). Questo mostra che l'intimità si è costruita piano 
piano. Un altro elemento che conferma questo è che "l'io" si riferisce prima a una cosa superficiale ("gli occhiali") e dopo a una cosa vera e personale ("la mia bocca").

In vari punti il testo cita il corpo umano (mano: bussassi - quando bussiamo, usiamo la mano; occhi: riferimento attraverso gli occhiali; bocca "entrassi alla mia bocca"; ed orecchie: quando si bussa alla porta qualcuno l'ascolta ). Questo ci farebbe dire che i sensi sono importanti, che il corpo, le sensazioni fisiche fanno parte della lettura.

$\mathrm{Ci}$ sono anche stratagemmi basati sulla grammatica.

Gli elementi del primo verso creano già il tono del testo.

La frase "Se ora tu bussassi alla mia porta" crea il tono dell'ipotesi. Questa frase è la protasi che è la prima parte di un periodo ipotetico, la parte che si riferisce alla condizione. Queste "condizioni" vanno dal verso uno fino al verso sette, dove si inizia l'apodosi che è la seconda parte, la conseguenza. Un altro aspetto interessante è che le due parti finiscono con la parola "successo" ( in sensi diversi e con funzioni grammaticali diverse: prima è un verbo e alla fine è un aggettivo). Nella prima parte "successo" fa pensare alla realtà e nella seconda parte si riferisce a una cosa più soggettiva come un sogno, un desiderio, perché il successo, la fama è un sogno.

L'autore usa anche due avverbi di tempo: ora e poi che sono avverbi enunciazionali proiettati in un futuro ipotetico che insieme stabiliscono una successione temporale che avvicina il momento dei pensieri dell'enunciatore.

C'è l'uso del discorso diretto che crea un tono teatrale (perché ci sono battute) e crea, anche un tono di oralità.

L'ultimo verso (che viene dopo il discorso diretto) sembra che sia una rottura nel testo perché non sembra che siano collegati, ma l'ultimo verso potrebbe anche essere una risposta alla domanda del discorso diretto.

Quando pensiamo agli stratagemmi sul piano dell'espressione, la strategia più visibile è l'allitterazione in "s" che crea l'effetto di una conversazione a bassa voce, come un sussurro. Questo sottolinea il carattere intimo della poesia. Un altro stratagemma è il gioco basato sulle vocali chiuse $(i, u)$ ed aperte $(a, o)$ che enfatizza il movimento del aprire e del chiudere che compare nel testo.

(I5)

Dopo aver letto il racconto per la prima volta, la prima cosa che mi è venuta in mente è il tema del tradimento perché il personaggio principale tradisce ed è tradito allo stesso tempo.

$\mathrm{Ci}$ sono tuttavia molti temi in questo racconto. Il tema principale è il rapporto fra la mafia e la politica, perché ci sono molte parole che riguardano questi elementi come: "mafia", "capofamiglia", "rielezione". C'è una parola invece che sottolinea proprio il legame fra la mafia e la politica: "commissione antimafia"

Il personaggio attraverso il quale il testo mostra il tema della mafia viene presentato con un tono di mistero. La prima cosa che fa riferimento al protagonista è un verbo all'infinito. Poi c'è un pronome: lui. Soltanto alla quarta riga si sa una cosa un pò più concreta sul protagonista, che è il suo ruolo sociale. Questo stratagemma atraverso il quale si va dal più indeterminato al più determinato è denominato catafora (che annuncia, ma non specifica il personaggio). Questa strategia crea anche il tono di mistero che è molto presente nel testo.

Un altro tema basato sul personaggio è il tema del doppio.

Nel titolo si vede la parola "doppia" vicino alla parola "onorevole" e questo collegamento fa venire in mente che l'onorevole ha qualcosa di doppio. Anche la parola "onorevole" ha qualcosa doppia perché fa riferimento alla professione del politico, ma fa anche pensare all'onore che riguarda il mondo della mafia.

Un altro aspetto che riguarda il doppio è l'uso dei verbi riflessivi come "vedersi" ed "ascoltarsi". È interessante osservare che i verbi riflessivi si riferiscono al personaggio principale e sono verbi senza desinenze diversificate per persona (non "mostrano" la persona alla quale si riferisce l'azione, per questo si potrebbe dire che non c'è in questo testo la vera e propria personalità dell'onorevole, il personaggio non sarebbe una persona determinata).

Ci sono anche "frasi doppie", non si può dire che sono frasi dell' enunciatore o se sono pensieri o battute del deputato: " 'Denuncia senza rumore.' 'Faremo i nomi dei collusi."”

Anche l'atteggiamento del protagonista è doppio: ha un accordo con la mafia, ma fa finta di essere contro i mafiosi e c'è anche un oggetto che sottolinea il doppio: la cravatta che usa a casa è nera e in TV ne ha una rossa. I colori potrebbero riferirsi alla politica: la cravata nera potrebbe fare riferimento alle "camice nere" (fascisti) e quella rossa forse fa riferimento ai comunisti, o magari ai brigatisti.

Un altro elemento che sottolinea il doppio è la TV che può essere vista come un personaggio: alla fine è come se fossero due personaggi, la TV che "dice" l'ultima frase del racconto mentre l'onorevolle che è già morto.

Quando è in TV la personalità (nonostante il personaggio non abbia una personalità vera e forte) è la più falsa possibile perché lui sembra essere un politico serio e questo non è vero, è l'unica cosa sicura di questo racconto.

Quando l'onorevole è dentro la TV sembra un attore perché recita davanti a tutti. Quando il deputato è in albergo si vede un pò meglio la sua vera identità: sappiamo che lui è orgoglioso, ad esempio. Allora si potrebbe dire che fra l'onorevole e la TV c'è un rapporto di alterità. 
Ci sono anche altri personaggi creati dall'enunciatore: i giornalisti ed i mafiosi, che non dicono nulla, benché le loro azioni si conoscanole atraverso l'enunciatore. Nessuno ha un nome, si sanno soltanto i ruoli sociali. C'è tuttavia un altro personaggio, D'Ottavio che ha un nome ma non dice nulla ed invece è un personaggio importante perché sa che l'onorevole ha tradito la mafia e per questo è stato ucciso.

L'enunciatore è anche una parte interessante del racconto, la maniera in cui l'ha scritto è veloce, le frasi sono corte, asindetiche e così si conoscono sia l'ethos dell'enunciatore che il ritmo ed il tono di mistero del testo.

Atraverso i personaggi si vede che il testo è figurativo perché usa figure che creano una situazione concreta, una storia che spiega un tema, fa finta di essere vera.

Un altro aspetto che crea l'illusione di verità è l'uso dei tempi verbali.

La storia è basata sul presente, tutte le volte che qualcuno legge questo racconto c'è la riatualizzazione dei fatti, il presente avvicina il lettore al testo.

$\mathrm{Ci}$ sono invece altri temi verbali come l'infinito che fa riferimento sia al doppio in qualche caso ( i riflessivi) che alla mancanza di una vera e propria personalità (verbi senza desinenze personali).

Compare nel testo anche un "flash back" che fa conoscere al lettore l'accordo con la mafia. Per parlarne viene usato il passato prossimo che crea un'immagine anteriore ai fatti del racconto, si vedono le cose successe prima dei fatti (si sa attraverso il passato prossimo qualche informazione sulla storia).

Viene usato anche il gerundio che crea l'effetto del doppio: "sorride ascoltandosi rispondere" può significare sia che sorride mentre si ascolta che sorride perché si ascolta.

Allora si potrebbe dire che il tempo e lo spazio creano l'effetto del doppio: "Come se il tempo e lo spazio offrissero sempre a quelli come lui una scappatoia".

\section{(I6)}

Dopo aver letto "La poesia oggi" per la prima volta, le prime cose che vengono in mente è che non sia molto convenzionale, perché è un po' ironica e questo tono non è molto comune nella poesia. Si può dire che è un testo metaletterario perché il tema si riferisce alla poesia stessa e anche come viene vista e sentita dalle persone, ma il tema centrale è dove si può trovarla.

La poesia può essere divisa in cinque parti e questo tema principale ne compare.

La prima parte (prima strofa) riguarda la poesia e suoi aspetti formali perché parla dei critici letterari "che siedono alle tavole rotonde". In questo brano compare l'ironia che può essere rappresentata dalle virgolette e perché queste tavole rotonde erano importanti (c'era un re) e per il tono della poesia non sembra che i critici abbiano così tanta importanza.

La seconda (parte) strofa si riferisce alla poesia attuale, che è vicina alle persone (non è idealizzata) e si può vederla da qualsiasi parte, anche dentro le persone "nelle facce della gente". Ma in questa parte le due primi versi si distacano perché c'è un "io" che parla e prende la responsabilità dell'ipotesi su di se ("io la posso indicare").

Dopo questo avvicinamento (la poesia fa parte delle persone) c'è un allontanamento, la terza parte (strofa) parla della poesia antica basata sulle donne idealizzate. Poi la poesia "si avvicina" un'altra volta (quarta strofa - quarta parte) e parla del quotidiano, si può vedere la poesia dentro l'atteggiamento delle persone e poi nell'ultima parte (ultimo verso) c'è la banalizzazione della poesia, le persone la vedono, ma questo non fa venire una azione alle persone che rimangono zitte.

Quest'idea di avvicinamento ed allontanamento è vista anche attraverso lo spazio, il tempo e la persona.

All'inizio della poesia ci sono indicazioni di spazio - ovunque, in questo paese ed a tavole rotonde: queste indicazioni vanno dal più indeterminato al più determinato e alla seconda strofa ci sono anche cose vicine, comuni: magazzini, cinema ecc.

Alla terza strofa c'è un altro allontanamento, parla delle famose cortigiane e crea così un'immagine che fa pensare alle poete cortigiani dunque alla poesia antica.

All'ultimo verso c'è il supermercato che è un posto comune in cui si vendono le cose, e questo dettaglio potrebbe essere un riferimento alla poesia che si è diventata commerciale.

Il tempo verbale fa parte di questa strategia perché all'inizio $\left(1^{\mathrm{a}}\right.$ e $2^{\mathrm{a}}$ strofa $)$ compare il presente. C'è anche un avverbio di tempo "oggi" che riatualizza la poesia tutte le volte che è stata letta.

Quando c'è l'allontanamento ( $3^{\mathrm{a}}$ strofa) i versi sono basati sul passato remoto che è un tempo che non è legato al presente, è un "tempo lontano" come è lontana quella maniera di fare la poesia ("l'Ideale lontano"). Potrebbe anche riferirse, questo tempo verbale, alla scrittura come una cosa fatta attraverso la tecnica perché il passato remoto viene principalmente usato nella letteratura (per sottolineare la forma letteraria del poeta cortigiano) o nei testi storici ( per sottolineare che questi tipi di poesie sono state fatte da molto tempo).

Quando c'è il passaggio da questa poesia alla "poesia di oggi" ci sono verbi impersonali (imprimersi, risciacquar) che potrebbero riferirsi alla mancanza di azione o di coinvolgimento delle persone. 
Alla fine (ultimo verso) c'è un'altra volta il presente. Questo verso sembra un discorso diretto, tuttavia non in maniera convenzionale.

In questa poesia ci sono una prima ( $5^{\circ}$ e $6^{\circ}$ verso) e una terza persona. Il discorso diretto potrebbe essere basato sulla stessa persona che dice di sapere dov'è la poesia perché in questi versi ci sono opinioni un po' personali.

Questo discorso diretto "vuole" colpire il lettore, fare un contrappunto fra la battuta (che fa finta di essere una voce) ed il silenzio della gente e così fa una critica alla società di consumo che non pensa (si tace davanti alla poesia che le circonda).

Questo brano dimostra che in questo testo c'è l'uso dell'ironia che è anche presente nelle virgolette usate per le "tavole rotonde" che può sottolineare il paragone con l'antichità e anche fare uno scherzo perché i critici non sono così importante (se le persone non pensano alla poesia non "pensano"a chi ne parla).

Pur essendo una poesia così "non convenzionale", l'autore usa gli stratagemmi tipici della poesia.

La poesia è basata su alcune figure che sono centrali. L'espressione "tavole rotonde" simboliza i critici, quelle persone lontane dalle altre come quelle della tavola rotonda del re Arturo. Un'altra figura basata sull'allontanamento è "fammose cortigiane" che fa riferimento alla poesia antica, basata sui temi inatingibili, lontani.

Ci sono anche figure che rappresentano un avvicinamento c'è "il supermercato" che segna la poesia commerciale e ci sono anche i "settimanali illustrati" che potrebbe essere simbolo della poesia che si guarda senza fare attenzione e poi se la butta via.

Ci sono anche allitterazioni: alla prima strofa c'è il suono della " $n$ " che sottolinea quell'idea che i critici siano lontano dalle persone comuni, perché questo suono riguarda il sogno, il lontano.

Alla seconda strofa c'è il suono della " $t$ ", della " $p$ " e della "d" che sono forti, fanno impatto.

Alla terza strofa c'è il suono della " $n$ " e della "s" che riguardano il sogno o fanno finta di che ci sia qualcuno che parla a bassa voce: questo brano si riferisce alla poesia antica.

L'ultima strofa è basata su un miscuglio di tutti i suoni e questo forse dice che tutti i temi possibili possono essere temi della poesia attuale.

\section{ALUNO J}

\section{(J1)}

Il texto è adosso Luca. Ha trent'anni. Aveva una memoria d'elefante ed adesso è un colabrodo. Fa un patto con il destino e non cumpre e mori.

"Memoria d'elefante" e "colabrodo" sono metafore che reforzano le espressione e creano un paradosso. Le elementi contrapposti sono il ricordo, l'elemento positivo, e la dimenticanza, l'elemento negativo.

I protagonisti del raconto sono: Luca e la sua memoria, un'auto e il destino.

Nel testo hanno espressioni riferite al tempo come "Guarda l'orologio". "Le sei meno un quarto". "Le sei meno dieci", etc.

Le espressioni provocano un effeto di apressamento del destino. Crea un'ansietà perché lui non ricorda chi ha segnato il gol del Milan e sono quasi le sei spaccate.

Nel testo hanno tré volte il discorso diretto: "Chi ha segnato il gol del Milan?", "Come si chiamava quel tuo compagno delle medie grasso grasso?", "Se non mi viene in mente prima delle sei, allora morirò entro un anno". Il discorso diretto crea l'illusione della realità.

Nel testo ha l'idea che il destino non perdona.

\section{(J2)}

La poesia che abbiamo ha come il tema principale l'abbandono.

L'uomo che narra la poesia (1a persona) è ironico e sarcastico. Ha sposato una donna, ma le ha lasciato. Dopo ha sposato ancora e dice chi ha lasciato anche lei. Lui parla di lei come se parla di un'oggetto "L'ho sposata".

Tutti i verbi sono usatti nella forma passata, però nei dialoghi sono usatti anche i verbi nel presente. Questo stratagemma crea l'effetto della realtà ed aprossima il lettore della situazione narrata. Anche il discorso diretto aiuta nell'effetto della realtà.

Nella poesia ci sono tre attori: la donna, l'uomo ed una terza persona. Nel primo dialogo la donna parla con l'uomo, però nel secondo e nel terzo dialoghi l'uomo parla con una terza persona sullo matrimonio.

Il tono della poesia fa il lettore pensare che l'io che parla non ama sua moglie e l'ultimo verso "parto alle sei" mostra come l'uomo è fredo e che fa parte della sua vita abandonare le persone. Quale è l'importanza che lui dà al rapporto? Me sembra che non molto, perché la poesia è freda, senza cuore e amore.

Lui gioca con il verbo andare: 
"Come è andata?" / "È andata / via"

Così, se può vedere che nel primo verso il verbo è usato per chiedere come sta, se bene, se male. Ma nel prossimo verso, usa il verbo andare con il senso di partire.

Nella poesia non c'è il linguagio poetico, ma le rime (partorito-partito; sposata-andata; lei-sei) e la struturazione creano il ritmo e danno la caracteristica di una poesia.

\section{(J3)}

Il tema principale del racconto è il tradimento.

Nel testo ci sono quattro personaggi: Paola, Duccio, Franca e Giorgio.

Duccio è un uomo sposato che ha tradito sua moglie e mi sembra che in quella situazione il tradimento non ha cambiato la sua vita.

Però, dopo vent'anni c'è qualcosa nel suo inconscio che l'impedisce di dormire. Il testo comincia "Non può dormire. Qualcosa lo tormenta (...) si rigira nel letto". Quet'immagine trasmette al lettore lo stesso sentimento di Duccio: il tormento.

Nel primo paragrafo, il narratore, onisciente, in terza persona, describe la scena e parla anche di Paola. Il narratore descrive Paola, ma con gli occhi di Duccio. Da questo punto di vista, lei ha capelli scuro, ora tinti, la sua guancia è piena e morbida, ha grandi occhi ingrigiti dagli anni. Dunque, c'è una contrapposizione fra un'immagine di una vecchia (capelli tinti, occhi ingrigiti) e una giovine (massa dei capelli, guancia morbida). Così, gli elementi positivi vengono atenuati dal tempo. Ė interessante che quando Duccio la vede addormentata e apparentemente tranquilla, si ricorda del tradimento. Dunque, c'è un'altra contrapposizione tranquillità X tormento, colpa.

Un altro attore che participa della costruzione del testo è il narratore. Lui vede le cose che una persona normale non può vedere ed è riuscito a vedere il pensiero di Duccio e lo mostra "Ma Duccio li immagina azzurri (...). E d'improvviso capisce. È per quel pomeriggio".

Ad un certo punto la voce del narratore si mescola con la voce di Duccio. Il discorso è indireto libero, senza vergolete "Dunque è così che vanno le cose, pensò al risveglio: nessun rimorso, nulla cambia. Si può tradire e farla franca, anche con se stessi. Si può tranquillamente convivere con i propri peccati".

Io penso che il discorso indireto libero è una strategia in cui la voce del protagonista è messa in dubbio, perché è detta attraverso la voce del narratore, però si mostra anche l'accesso del narratore al pensiero di Duccio. Così, il lettore ha una visione esterna della scena, ma anche una visione interiore dei personaggi.

Nel testo viene usato il tempo presente e quest'uso crea l'effetto di simultaneità fra la scena e il racconto. Questa strategia presentifica il lettore, l'aviccina alla scena e crea anche il senso della verità.

Ci sono altri elementi che creano verossimiglianza nel testo. Esempi:

$\circ \quad$ La descrizione fisica e psicologica dei personaggi;

- Il discorso diretto, perché ci fa ascoltare le parole dei personaggi come sono stata detta;

○ L'uso del tempo verbale presente;

○ I personaggi vengono costruiti con i nomi, ruolo sociale, hanno voce;

○ L'uso di locuzione temporale ("È per quel pomeriggio". "Esattamente vent'anni prima".)

$\mathrm{Ci}$ sono anche alcuni verbi al passato prossimo. Questo tempo stabilisce una correlazione tra il passato e il presente. Ma i verbi al passato remoto allontanano il tradimento e presentificano che non l'ha fatto più. Attraverso il tempo verbale, il narratore accentua quello che oggi è importante per Duccio. Mi sembra che la colpa è più importante che il tradimento. Così, l'azione è allontanata mentre le sue conseguenze sono presentificate.

Le frasi del testo sono brevi, non hanno molti connettivi, quindi c'è un effetto di suspense. La narrativa è accelerata e concitata come Duccio. La strutura narrativa aiuta a creare il sentimento di tormento presente nel testo. Ci sono anche molte parole che si riferiscono a questo sentimento: "peccatti", "rimorso", "tradire".

"Dunque è così che vanno le cose, pensò al risveglio: nessun rimorso, nulla cambia. Se può tradire e farla franca, anche con se stessi. Se può tranquillamente convivere con i propri peccati”. Non si può sapere certamente qual'è la voce del narratore e qual'è la voce di Duccio, tuttavia mi sembra che Duccio ha voglia di convincere a se stesso. Lui tenta spiccare la colpa del suo pensiero. C'è la colpa però Duccio cerca di guardare la situazione con gli occhi di tranquillità per allontanare la colpevolezza.

È interessante nuotare il riferimento al campo visivo del testo: oscurità, semioscurità, coloro dei capelli, lampione, occhi ingrigiti, occhi azzurri. Tutti questi elementi si rimetono al dubbio, ha contrapposizione tra il chiaro e lo scuro, cioè, a realtà e quello che non si sa sicuramente.

Possiamo anche associare la semioscurità a tristezza, al tormento, all'ethos di Duccio.

Gli occhi di Paola erano azzurri perché lei era felice e adesso sono ingrigiti perché ha dubbio. Questo è un aspetto interessante perché in nessuno momento c'è la certezza che lei sà la verità, però alla fine del testo Paola non dorme, dunque resta il dubbio anche per il lettore. E così il fuoco che prima era Duccio, adesso è Paola. 
Gli occhi il specchio dell'anima e Paola mostra attraverso il colore degli occhi il suo sentimento, la sfiducia e la sua trsitezza. Può essere che Duccio li immagina azzurri perché voglia pensare all'innocenza e pace di Paola. Il narratore vede gli occhi nell'oscurità, cioè, ci sono gli occhi di Paola, di Duccio, ma anche gli occhi del narratore.

\section{(J4)}

La poesia da Patrizia Cavalli parla di un rapporto d'amore idealizzato che si realizza solo nell'immaginazione del soggetto.

La prima parola della poesia è un "se", cioè, una congiunzione condizionale che ci rimette al periodo ipotetico della possibilità. Questo periodo è proiettato verso un futuro il quale è attenuato dall'uso del congiuntivo imperfetto "bussassi". Anche il verbo "bussassi" si riferisce a un desiderio, a una possibilità e non a una situazione concreta.

Nel primo verso ci sono riferimenti di tempo, di spazio e di persona. C'è un tu in "Se ora tu bussassi" che pressupone la presenza di un "io" che viene rafforzato dal possessivo "mia". C'è la parola "ora", un avverbio temporale presente e proiettato nel mondo dell'ipotese che crea la sensazione di avvicinanza del lettore alla poesia. E il primo verso ha anche lo spazio della situazione "mia porta". L'io della poesia definisce il tempo, la persona e lo spazio, cioè, non si parla di qualsiasi posto, ma si tratta di uno spazio che è stato definito dall'io.

$\mathrm{Ci}$ sono quattro congiunzioni coordinative "e" le quali creano nel lettore l'aspettativa della prossima scena e confermano le successioni di fatti che vengono stabiliti dall'avverbio temporale "poi". Le articulazioni temporali "ora" e "poi" sono il leggame con il momento di enunciazione.

Il discorso diretto presente nella poesia crea l'effetto di concretezza immaginaria perché nonostante sia la voce del "tu" questa è data attraverso l'immaginazione dell'io. Anche le parole di questo "tu" danno caratteristiche e concretezza al soggetto immaginario.

Mi sembra che le parole fra virgolette siano una sorpresa. È interessante che queste parole siano in tono colloquiale e sembrino una frase orale detta davvero perché c'è quello "ma" che ci riporta all'oralità e il vocativo "amore mio". Il discorso diretto si ricollega alla parte parte finale della poesia attraverso le ripetizioni della parola "successo". Il primo "successo" indica un avvenimento passato, cioè, è un verbo coniugato al passato prossimo e il secondo "successo" indica la buona repercussione di uno spettacolo. Dunque sentire quelle parole, per il soggetto, sarebbe un pezzo teatrale. In questo modo la parte finale del testo conferma la sorpresa delle parole fra virgolette.

Questa repetizione della parola "successo" crea un effetto sonoro ma anche de significato perché le due volte sono in posizione finale. La protosi, cioè, la condizione del periodo ipotetico, finisce con "successo" e l'apodosi, cioè, la conseguenza finisce anche con "successso". Questa situazione crea un effetto di fine di unità che accentua la sonorità.

Possiamo vedere che c'è l'assonanza attraverso le ripetizioni delle vocali “a”, “i”, "o". C'è alliterazione del fonema "s" che provoca l'idea del sussurro e ci sono rime interni ed esterni, come "occhiali", "uguali', "disuguali” , "bussassi" e "entrassi". C'è anche la rima della parola "successo" nei due ultimi versi, questa può essere considerata ricca perché cambiano le classi grammaticali.

L'io che parla con un 'tu" in maniera intima e colloquiale, però questo viene interotto nel discorso diretto quando invece è il "tu" che parla con "l'io". È interessante che nell'apodosi non ci sia neanche la prima persona del discorso nemmeno la seconda.

Quando ci sono riferimenti allo spazio mi pare che siano intimi e sessuali. Prima, il riferimento è la "porta" un limite fra il mondo fuori e lo spazio domestico. Dopo il limite è la bocca e allora è più intimo. Questo movimento spaziale è dal mondo esterno allo spazio della vita privata, dell'intimo del soggetto. E quest'intimo viene rafforzato delle parole che si riferiscono al corpo umano. Così i verbi "togliere" e "bussare" indicano le mani, gli "occhiali" ci rimettono alla vista, "bocca" si riferisce al gusto, c'è il discorso diretto che ci rimette alle orecchie. Così, la poesia fa riferimento ai sensi del corpo umano e sottolinea la parte carnale.

Penso che la figura di "togliere gli occhiali" mi abbia colpito di più perché ci mostra che nella vita privata non c'è bisogno di maschere o non dovrebbe averne bisogno.

Così, alla fine, possiamo pensare al rapporto amoroso in cui il successo sarebbe possibile solo nel piano artistico. C'è la contrapposizione fra finzione e realtà. La scena viene descrita attraverso parole colloquiale che ci riportano alla realtà ma anche all'oralità del teatro. Anche il discorso ci rimette a un fatto della vita quotidiana però lo stesso soggetto dice che questo "sarebbe un pezzo di teatro" e questo pezzo sarebbe "di successo". Dunque tutta la poesia è un'ipotese e ci rimette alla finzione, così il rapporto amoroso sarebbe una rappresentazione teatrale.

(J5)

Il testo "L'onorevole doppia chance" ha come tema il rapporto tra mafia e politica. Le scelte lessicali che ci permettono di riconoscere questo tema sono: commissione antimafia, cosche, Cosa Nostra, capofamiglia, rielezione, voti, vicepresidente, Onorevole ecc. 
Un altro tema del testo sono i mass-media e li vediamo attraverso le parole: giornalista, TV, radio, intervista, spettatori ecc.

L'altro tema è la questione del doppio. Il titolo del racconto ci dà l'idea della dualità e che viene rafforzata dalle parole: scappatoia, doppia vita, ascoltarsi, ubiquità e vedersi.

Il titolo è ambiguo perché "onorevole" può essere interpretato tanto come deputato, quanto come aggettivo per la "doppia chance". Anche lo spazio è doppio perché le azioni descritte si svolgono in TV e nell'albergo. Moltre, il tema del doppio è rafforzato anche a causa della dualità nella funzionalità dell'uso dell'infinito e del gerundio.

È doppio anche l'uso delle virgolette perché ci sono due tipi. Uno dei quali introduce il ricordo di quello che è stato già detto “", mentre l'altro introduce un discorso diretto vero $<<>>$.

C'è un narratore in terza persona che conosce il pensiero dell'Onorevole ma non quello degli altri e questo permette di creare l'effetto di sorpresa alla fine del racconto. Alcune volte la voce del narratore si mescola alla voce del personaggio come per esempio quando si legge "Funziona. Rielezione assicurata" e non si sa se è un commento del narratore o un pensiero del personaggio.

Il protagonista è introdotto in maniera cataforica e graduale. Così, prima c'è un infinito "Buffo essere nella stanza", dopo c'è un verbo alla terza persona singolare "mentre risponde" e nella terza riga appare il pronome personale "lui". La catafora annuncia il personaggio ma non lo specifica e così, piano piano, la sua introduzione va dal vago al determinato, uno stratagemma che ha come obiettivo quello di far crescere l'interesse di chi legge.

Il protagonista non ha un antroponimo, ma ha una professione. È il vicepresidente della Commissione Anti-mafia e il lettore lo sa perché viene detto dal giornalista.

$\mathrm{Ci}$ sono altri personaggi come il giornalista, il mafioso, il sicario e D'Ottavio che è l'unico per il quale si usa un antroponimo.

L'enunciatore ha scelto frasi brevi, veloci e assindetiche che riproducono velocità e dunque creano l'immagine di un enunciatore concitato.

Il tempo principale del testo è il presente che crea l'illusione della contemporaneità tra chi racconta e chi legge, coiè, è l'illusione di parlare in presenza degli avvenimenti e dei lettori ed è uno stratagemma di riattualizzazione a ogni lettura.Ci sono altri tempi verbali: l'infinito, il congiuntivo imperfetto, il gerundio, l'infinito passato, il futuro e il passato prossimo. Quest'ultimo è un'anteriorità rispetto al momento di riferimento presente e crea un'apertura verso il passato.

L'ultima frase del racconto viene detta dall'Onorevole, ma in un momento in cui sappiamo che era già morto: "Temo di più per le sorti dei valori che rappresento". C'è ancora il tema del doppio e ci fa che vedere la contrapposizione fra vita e morte è il tema più astratto del testo.

C'è la contrapposizione fra alterità ed identità a partire del momento in cui il protagonista "cambia" faccia rispetto al suo coenunciatore. Così, alla TV si mostra serio, responsabile e nemico della mafia, ma in albergo lui si toglie la maschera e si vede la verità, cioè, il suo rapporto con D'Ottavio.

"Doppia vita. Anche tripla magari". Si vede un soggetto che si modifica a seconda dello spazio che occupa.

Il testo è figurativo perché ha oggetti concreti come, per esempio, le persone, la TV, il sicario, per rappresentare il tema della mafia e gli altri. Questo l'avvicina alla realtà.

(J6)

La poesia che ha come titolo "La poesia oggi" tratta il tema della propria poesia, cioè il posto in cui la troviamo e come le persone reagiscono a essa. C'è anche un altro tema riguardo all'efemerità delle cose nella vita.

Nonostante la poesia abbia quattro strofe possiamo fare un altra divisione. La prima parte sarebbe dalla riga uno alla riga sei perché ci riporta all'universo della critica letteraria e degli intellettuali. Gli elementi che aiutano a creare questo universo sono: "tavole rotonde", "poesia oggi”, "funzione del poeta”, "premmi”. La seconda parte sarebbe dalla riga sette alla riga quindici e mette in evidenza il luogo in cui si trova la poesia oggi e l'idea del consumismo. Gli elementi che inseriscono questo tema sono: "grandi magazzini”, "pubblicità", "cinema". Però, in questa parte c'è un'altra che si potrebbe staccare: dalla riga nove alla riga undici. Questo pezzzo ha una sintassi diversa, il tempo verbale non è quello degli altri pezzi e anche la scelta lessicale è diversa, come per esempi "cortigiani", "Ideale lontano". Questi elementi ci riportano alla poesia classica. Per finire la suddivisione, ci sarebbe la quarta parte che è l'ultima riga e ci riporta all'atteggiamento delle persone verso la poesia.

Nel testo ci sono avverbi, aggettivi e tempi verbali che si riferiscono al tempo della poesia. Dunque ci sono elementi che riguardano il presente e a questo punto è interessante vedere l'introduzione del senso di tempo presente dal titolo della poesia. Questo è rafforzato attraverso la scelta delle parole: "ci sono", "saprei", "oggi", "guarda", "tace", "entra", "già". Mentre ci sono elementi che riguardano il tempo passato: "instillarono", "vissero" e "lontano". Dunque questa contrapposizione fra presente e passato crea l'idea di due mondi contrapposti cioè il mondo classico (introdotto dai verbi al passato e rafforzato dal lessico che riporta alla poesia classica) e la poesia oggi. Un altra cosa 
interessante è che l'avverbio “oggi” è un elemento enunciazionale e deitico che riatualizza la lettura creando l'effetto di senso di essere sempre "oggi".

Compaiono alcuni riferimenti allo spazio. Ci sono: "supermercato", "grandi magazzini", "pubblicità", "cinema", "settimanali illustrati". Questi si riferiscono agli spazi del mondo del consumo. Mentre invece ci sono altri elementi: "questo paese", "tavole rotonde", "cuore del poeta". È interessante vedere il movimento dallo spazio generale "questo paese" allo spazio specifico "supermercato". Poco a poco lo spazio viene specificato e delimitato.

C'è un gioco di persona nella poesia. La prima strofa è in terza persona, così come nella terza e quarta strofe. Però, nella seconda strofa c'è un "io" che viene inserito attraverso il verbo "saprei". Dopo c'è un "io" espresso direttamente "questa sì, io la posso indicare". Questo stratagemma crea l'effetto di senso di soggettività ed opinioni personale. L'alternanza di persona crea l'effetto di avvicinarsi alla poesia e allontanarsi.

Alla fine c'è un discorso diretto perché la frase è introdotta da un trattino. E, secondo me, è una maniera di mettere in evidenza l'indiferenza delle persone verso la poesia: "- La gente guarda e tace, entra al supermercato".

La parola "gente" ci rimette alla massa di persone, cioè nonostante si riferisca alle persone, lo fa in maniera generale, non si individua. Così come il mondo dei magazzini, del supermercato, della produzione di massa. Tutto diventa consumo e le persone perdono il loro senso di individuo. La parola supermercato ci mostra la società consumista, la mancanza di soggettività e sensibilità per capire e sentire la poesia.

Possiamo vedere anche la ripetizione delle parole "poesia' e "poeta". Questi rafforzano il tema di cui tratta il testo: la propria poesia. E alcune volte c'è l'uso delle virgolette. Mi pare che questo stratagemma ironizzi la funzione del poeta o la poesia oggi. Se la gente guarda la poesia e tace ed entra al supermercato, la poesia non coinvolge nessuno, non espressa niente che arriva al cuore delle persone. Dunque la poesia diventa un testo normale così come il poeta. Secondo me, cè questa ironia anche nell'uso delle virgolette nelle parole "tavole rotonde". Nel mondo classico la tavola rotonda era una cosa importante, un posto in cui i cavallieri discutivano cose serie e oggi le persone che siedono attorno a queste "tavole" per scrivere e dare premmi sono inutili.

Dunque, si vede questa contrapposizione fra la poesia nel mondo classico e oggi si vede anche che la donna che ispirava il poeta e che era irragiungibile adesso fa la pubblicità delle birre, delle cose. C'è un abassamento del tema. Le cose che erano considerate importanti adesso sono considerate normale. Può essere che una delle ragione di tutto questo è la velocità delle informazioni come per esempio i "settimanali illustrati" che si legge e si butta via. In questo testo la poesia è nello stesso piano di queste cose: è un prodotto che si butta via. 